\title{
Марион Краузе
}

\section{Динамика механизма восприятия слова \\ при различных условиях овладения иностранным язЫкОМ}

Verlag Otto Sagner München - Berlin - Washington D.C.

Digitalisiert im Rahmen der Kooperation mit dem DFG-Projekt „Digi20“

der Bayerischen Staatsbibliothek, München. OCR-Bearbeitung und Erstellung des eBooks durch den Verlag Otto Sagner:

http://verlag.kubon-sagner.de

( bei Verlag Otto Sagner. Eine Verwertung oder Weitergabe der Texte und Abbildungen, insbesondere durch Vervielfältigung, ist ohne vorherige schriftliche Genehmigung des Verlages unzulässig. 
$<36624115770014$

$<36624115770014$

Bayer. Staatsbibliothek 


\title{
SPECIMINA PHILOLOGIAE SLAVICAE
}

\author{
Begründet von \\ Olexa Horbatsch und Gerd Freidhof \\ Herausgegeben von \\ Gerd Freidhof, Peter Kosta, Holger Kuße \\ und Franz Schindler
}

Band 134

Марион Краузе

\begin{abstract}
Динамика
механизма восприятия слова при различных условиях

овладения иностранным языком
\end{abstract}

VERLAG OTTO SAGNER MÜNCHEN 


\section{PVA}

2002.

2936

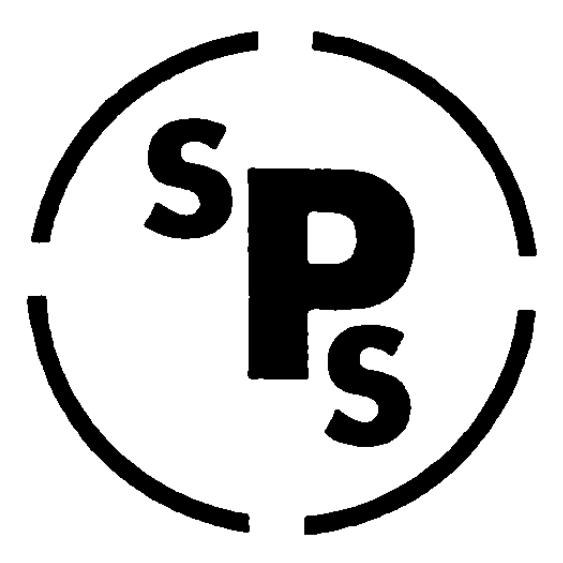

Verlag Otto Sagner, München 2002. Abteilung der Firma Kubon und Sagner, München. Druck: Völker und Ritter GmbH, Marburg/Lahn.

ISBN 3-87690-788-8

ISSN 0170-1320 
In memoriam Alla Solomonovna Stern $(1941-1995)$ 


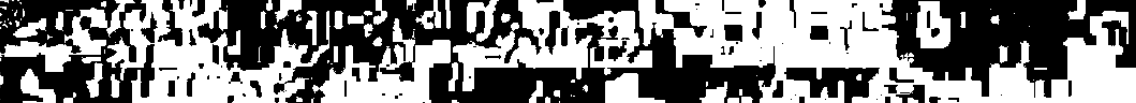

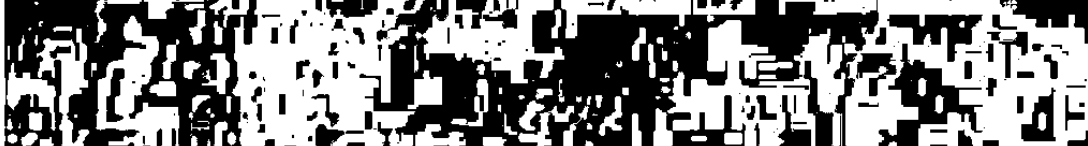
3)

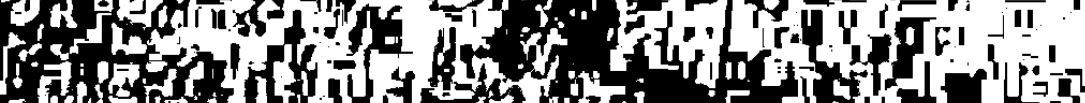
for

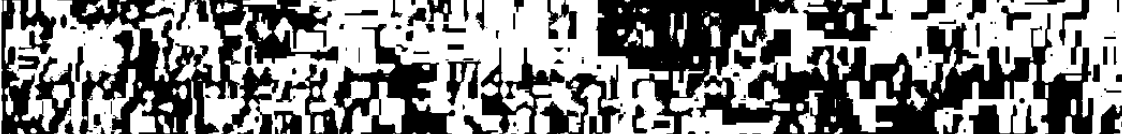

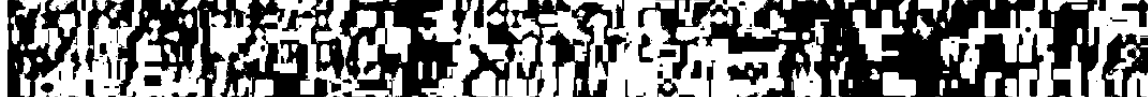

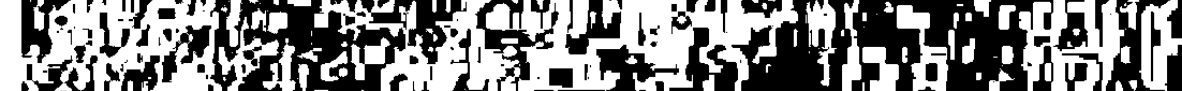

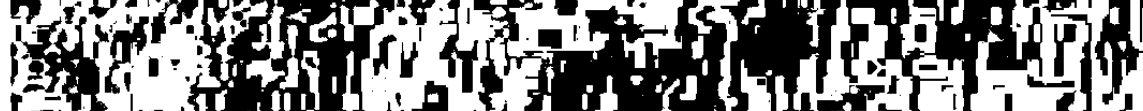

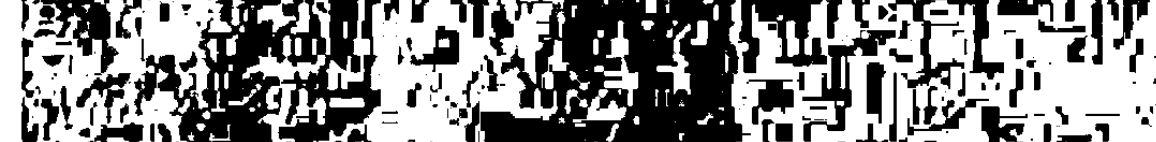

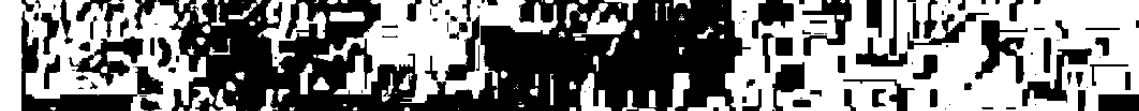

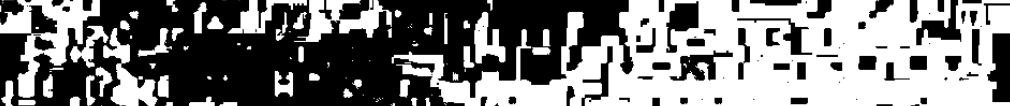
$\operatorname{lol}_{10}$

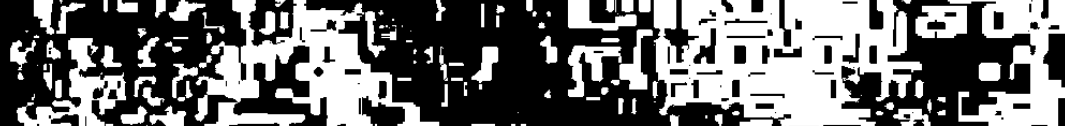
Find

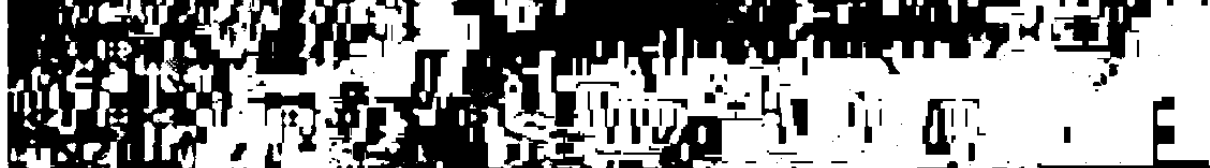
it

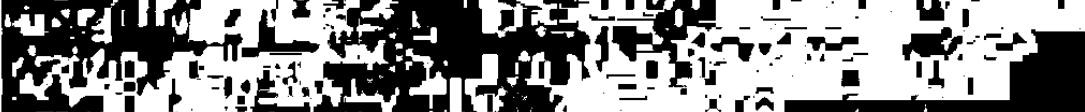
if $=1$ a

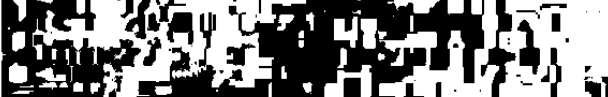
3.

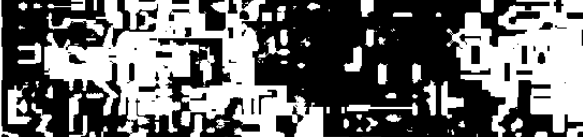

Ex 1 ing

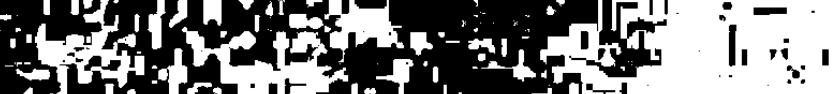

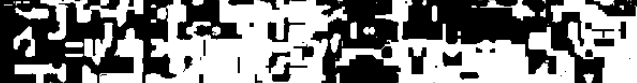

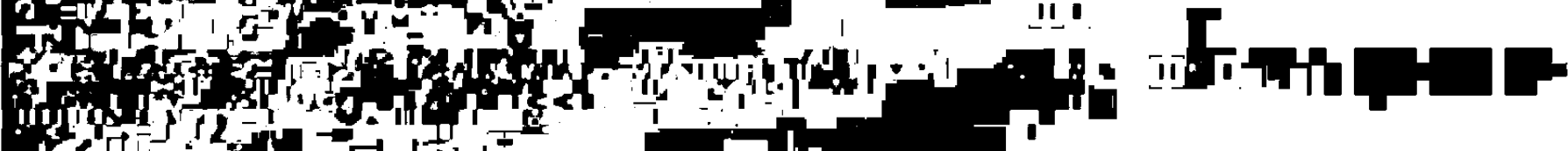
ond

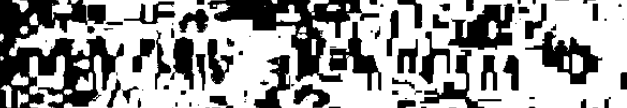

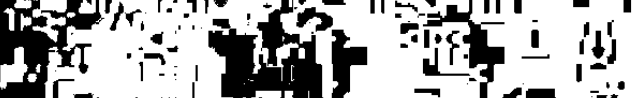

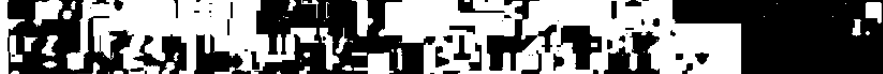

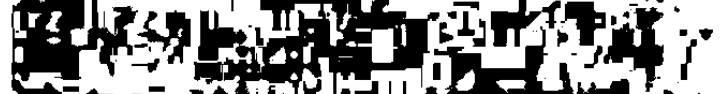

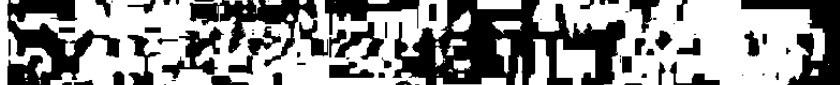

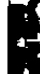
(1)

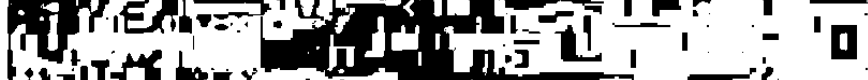

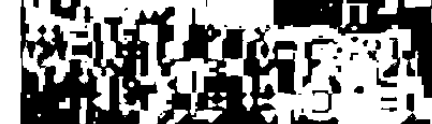

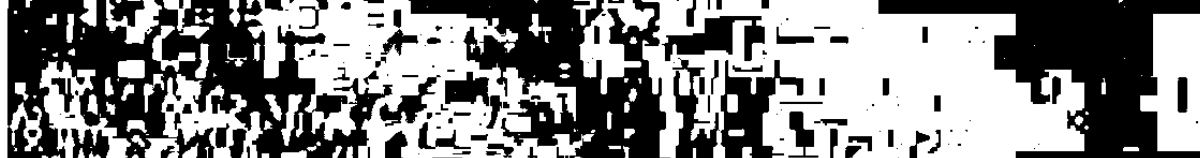

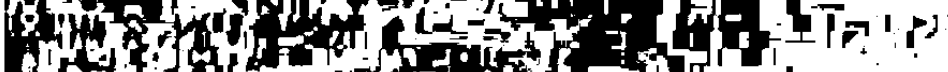

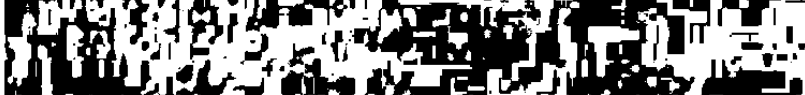
If

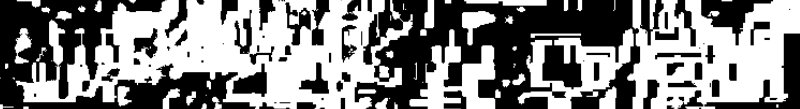
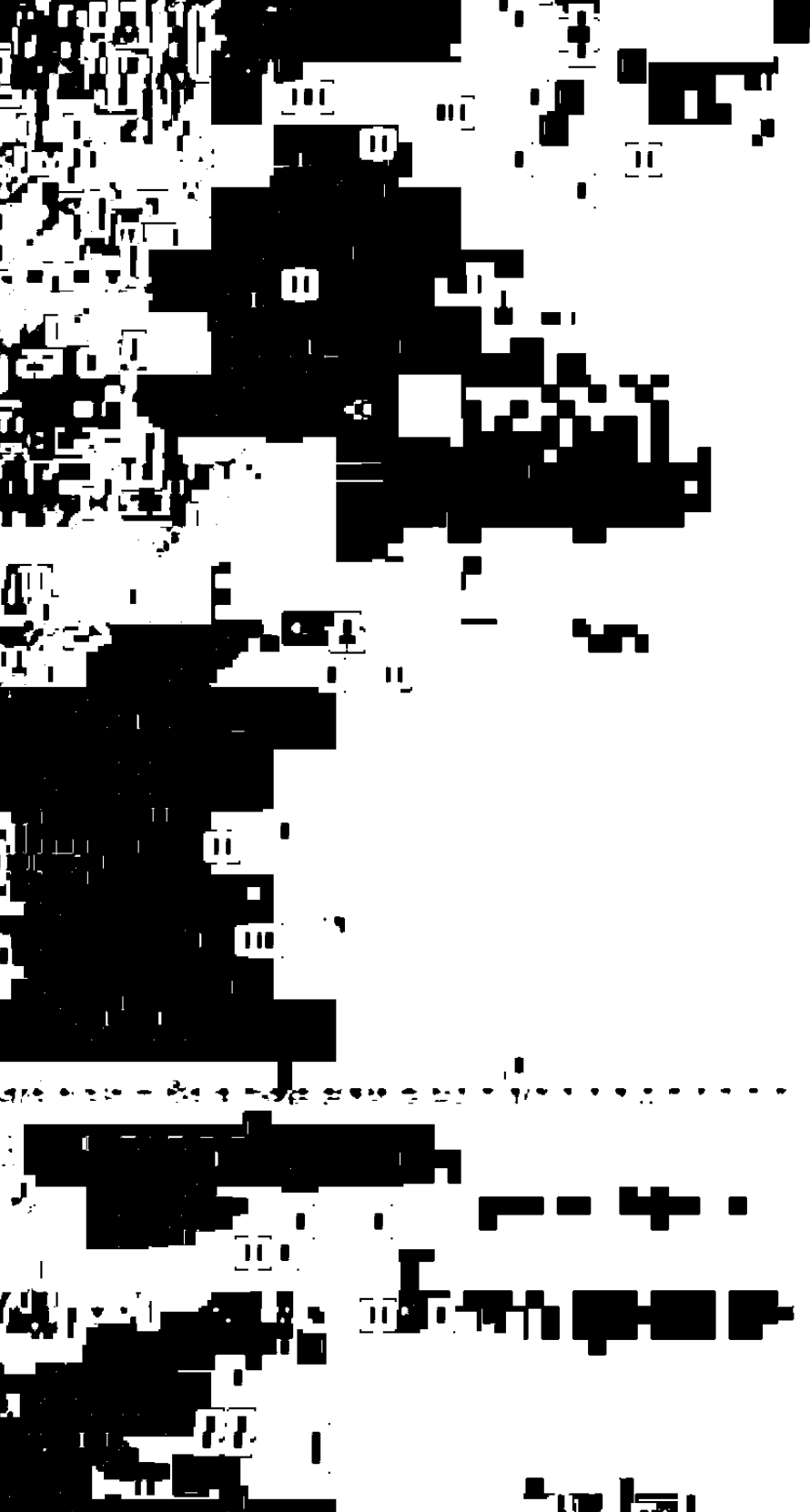


\section{Vorbemerkung}

Die vorliegende Untersuchung zur Dynamik des Perzeptionsmechanismus wurde bereits im Oktober 1989 an der Universität Leningrad verteidigt. $\mathrm{Zu}$ dieser Zeit arbeitete ich als wissenschaftliche Assistentin am Institut für Sprachwissenschaft der Friedrich-Schiller-Universität Jena, Wissenschaftsbereich Slavistik. Dank der Fürsprache der damaligen Bereichsleiter, Herrn Prof. Dr. sc. H. Baumann und Frau Dr. sc. R. Stöckl, und der Unterstützung durch die Universität konnte ich die Dissertation im Rahmen einer so genannten Fernaspirantur am Lehrstuhl für Phonetik der Universität Leningrad erarbeiten. Damit wurde mir Gelegenheit gegeben, mich entsprechend meinen wissenschaftlichen Neigungen in einem Forschungsgebiet an der Schnittstelle von theoretischer und empirischer Linguistik zu qualifizieren.

Das methodische und theoretische Wissen, das ich während dieser Arbeitsphase erwarb, prägen meine Herangehensweise an linguistische Probleme bis heute. Vor dem Hintergrund einer breiten und fundierten traditionellen philologischen Ausbildung, die ich während meines Studiums in Leningrad erhalten habe, konnte ich mir psycholinguistische Fragestellungen und Methoden und statistische Verfahren aneignen. Besonderen Anteil an diesem Werdegang hat meine viel zu früh verstorbene Mentorin, Frau Dr. phil. habil. Alla Solomonovna Štern. Mit der Veröffentlichung der Dissertation möchte ich noch einmal Dank sagen für all das, was ich von ihr lernen durfte. Bedanken möchte ich mich auch bei meiner Familie. Damals wie heute unterstützt sie mit viel Verständnis meine wissenschaftliche Arbeit.

Den entscheidenden Anstoß zur Veröffentlichung der Arbeit gab mir die Zusammenarbeit mit russischen Kolleginnen und Kollegen, die in jüngster Zeit verschiedene Aspekte der zugrunde liegenden Forschungsrichtung aufgriffen. Das zeigte mir, dass die Ergebnisse der Arbeit - sowohl in theoretischer als auch methodischer Hinsicht - nach wie vor aktuell sind. Um so mehr möchte ich nicht auf einen aktualisierenden Kommentar verzichten; er beendet die vorliegende Publikation.

Ich danke Natalija S̆abanova für ihre Hilfe bei der technischen Fertigstellung der Druckvorlage.

Mein Dank gilt auch Herrn Prof. Dr. Gerhard Freidhof und Herrn Dr. Holger Kuße, die sich bereit erklärten, die Arbeit in ihrer Reihe zu veröffentlichen. 


\section{СОДЕРЖАНИЕ}

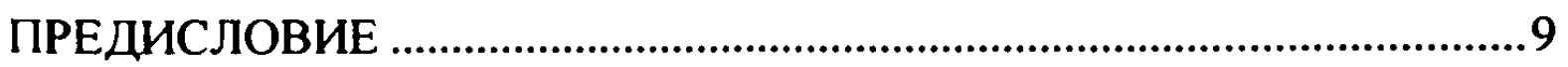

1. ТЕОРЕТИЧЕСКИЕ ОСНОВЫ ИССЛЕДОВАНИЯ...........................11

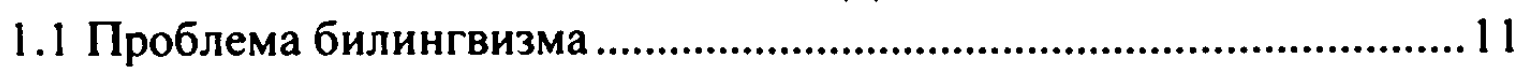

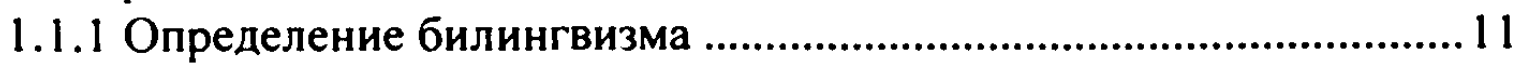

1.1.2 Проблема классификация билингвизма ...................................... 12

1.1.3 Понятие интерференции ......................................................... 14

1.2 Слуховое восприятие как многоуровневый процесс.......................15

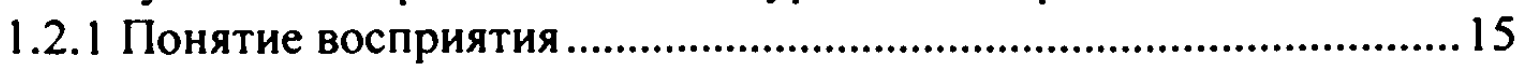

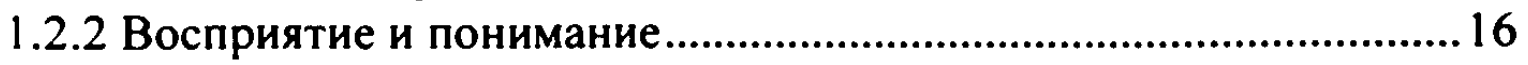

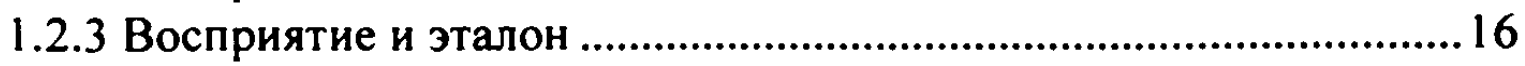

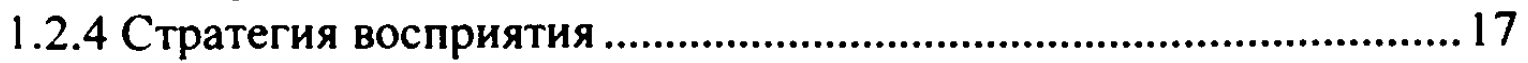

1.2.5 Факторы, влияющие на восприятие речи ...................................... 17

1.2 .6 Предмет исследования .................................................................... 18

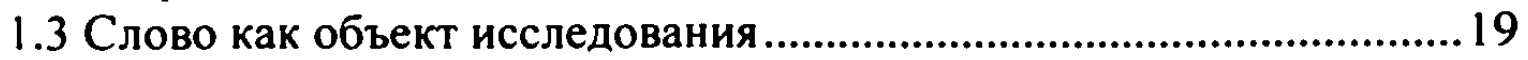

1.3.1 Слово как опорный элемент сознания ...................................... 19

1.3.2 Проблема лингвистического определения слова.......................... 19

1.3.3 Слово как объект психолингвистических исследований............20 2. МЕТОДИКА ПРОВЕДЕНИЯ ЭКСПЕРИМЕНТОВ И СПОСОБЫ

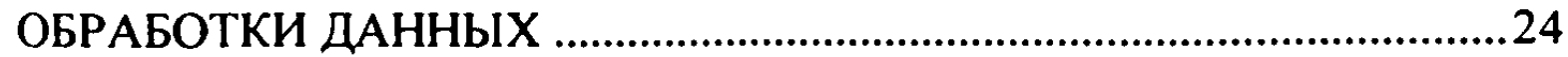

2.1 Экспериментальный материал ........................................................24

2.1.1 Принципы отбора материала .........................................................22

2.1.2 Характеристика лингвистических признаков ............................28

2.1.3 Комментарии к факторам ...............................................................229

2.1.4 Характеристика речи дикторов.....................................................37

2.2 Методика проведения экспериментов .........................................38

2.2.1 Запись материала и функция помех …….......................................38

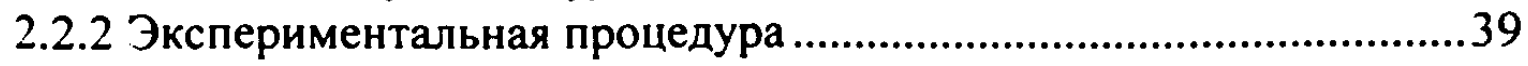

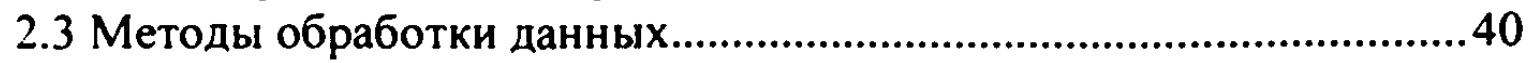

2.3.1 Дисперсионный анализ .......................................................40

2.3.2 Ранговая корреляция ....................................................................4

2.3.3 Анализ восприятия по градациям факторов.................................42

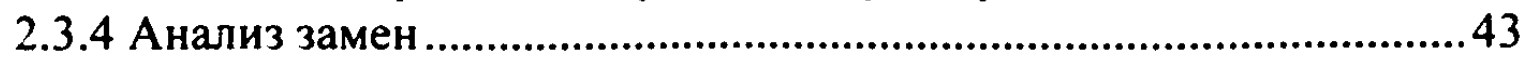

3. ВОСПРИЯТИЕ НЕМЕЦКИХ СЛОВ НЕМЦАМИ .............................44

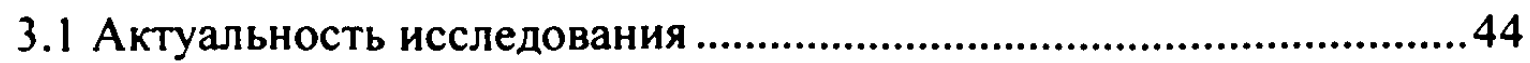

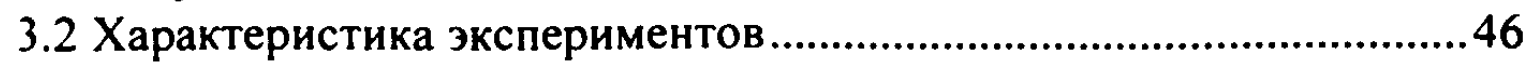

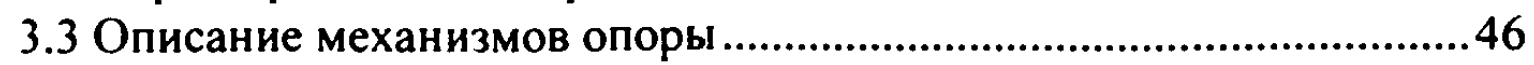

3.3.1 Механизмы опоры в разных условиях восприятия ......................46

3.3.2 Сопоставление механизмов опоры носителей немецкого и русского языков .....................................................................................49 


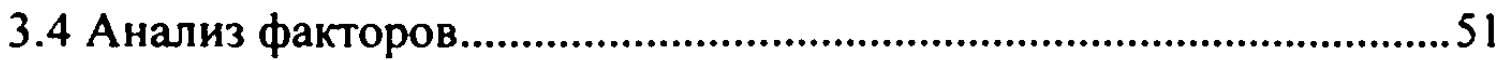

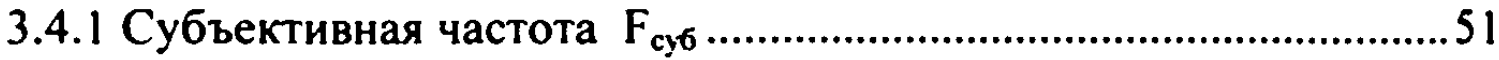

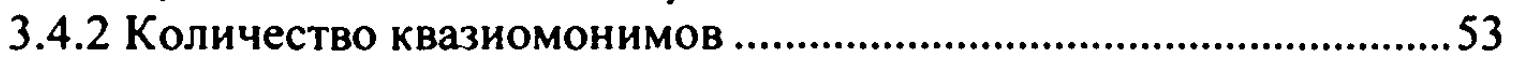

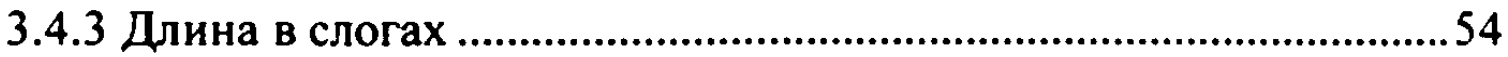

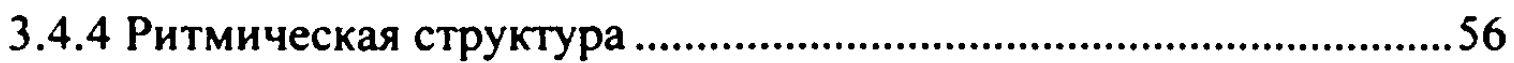

3.4.5 Факторы морфемного уровня ......................................................59

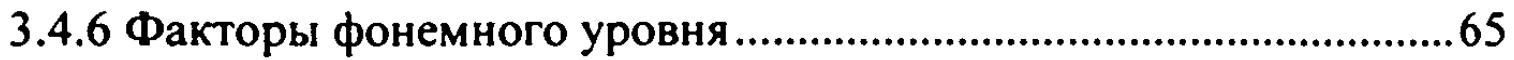

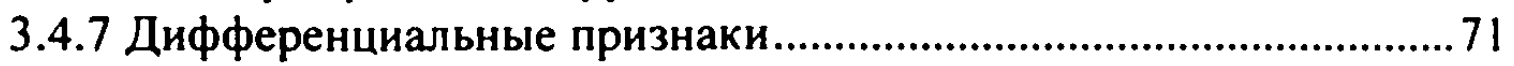

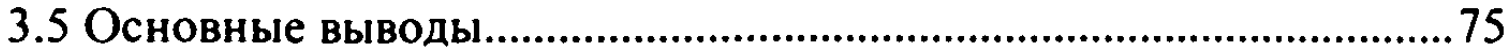

4. ВОСПРИЯТИЕ РУССКИХ СЛОВ НЕМЦАМИ (КОРПУС А) ...........77

4.1 Характеристика испытуемых корпуса А ………................................77

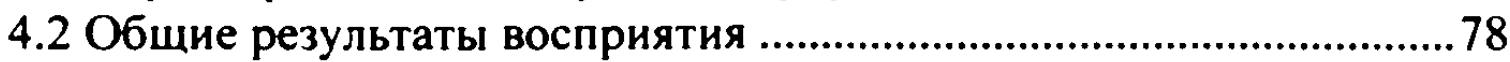

4.3 Результаты дисперсионного анализа..................................................79

4.4 Результаты по ранговой корреляции .................................................8

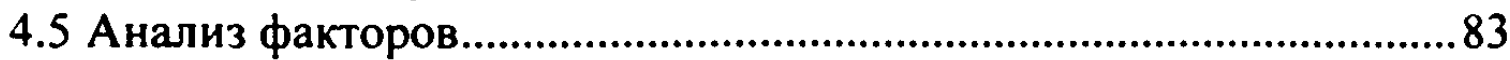

4.5.1 Объективная частота $\left(\mathrm{F}_{\mathrm{o6}}\right)$, субъективная частота $\left(\mathrm{F}_{\mathrm{cy6}}\right)$............83

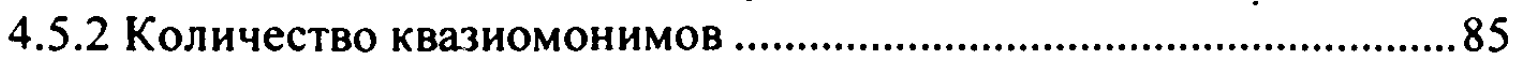

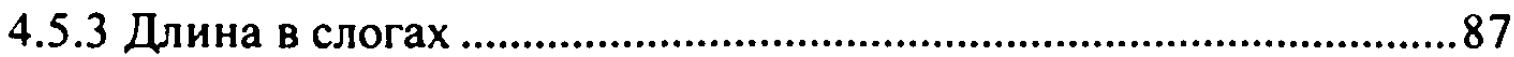

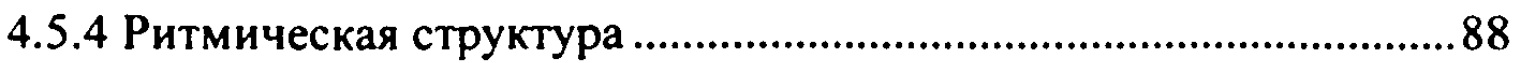

4.5.5 Признаки морфемного уровня ......................................................91

4.5.6 Признаки фонемного уровня...........................................................99

4.5.7 Дифференциальные признаки....................................................... 105

5. ВОСПРИЯТИЕ РУССКИХ СЛОВ НЕМЦАМИ (КОРПУС Б).........110

5.1 Характеристика испытуемых ......................................................110

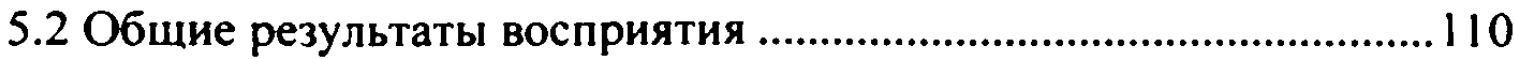

5.3 Результаты дисперсионного анализа...............................................113

5.4 Результаты по ранговой корреляции...............................................115

5.5 Анализ факторов....................................................................117

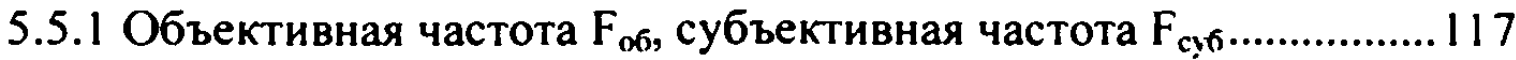

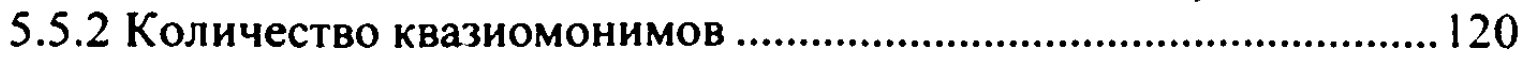

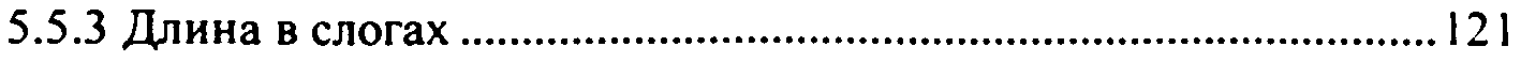

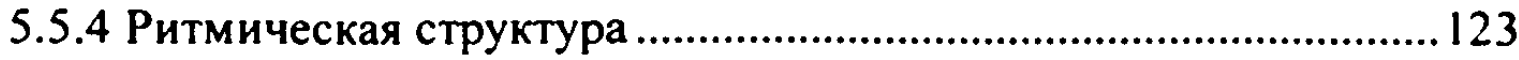

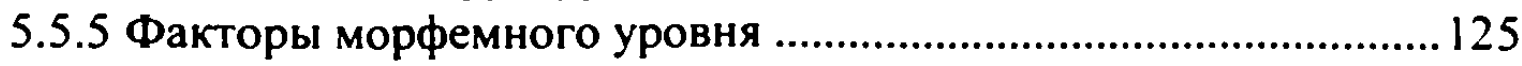

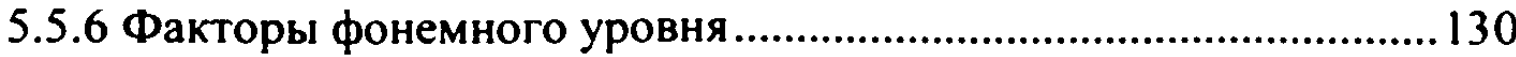

5.5.7 Дифференциальные признаки........................................................ 134

5.6 Анализ восприятия незнакомых слов ......................................... 137

6. ОБСУЖДЕНИЕ РЕЗУЛЬТАТОВ И ВЫВОДЫ ................................ 140

6.1 Гипотеза об универсальности механизма опоры при восприятии изолированного слова ...................................................................... 140

6.2 Обшность и специфика стратегий восприятия в родном и изучаемом языках 
6.3 Динамика формирования механизма опоры на изучаемом языке 142

6.4 Особенности поведения факторов в механизме восприятия на

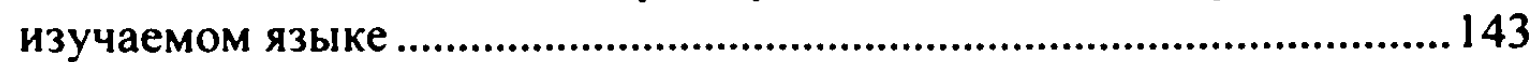

6.5 Общее составление механизмов восприятия ……....................... 146

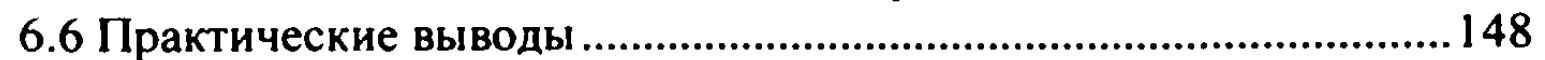

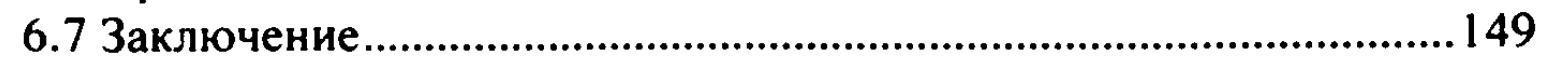

7. СПИСОК ИСПОЛЬЗУЕМЫХ В РАБОТЕ СОКРАЩЕНИЙ.............151

8. СПИСОК ИСПОЛЬЗОВАННОЙ ЛИТЕРАТУРЫ ............................153

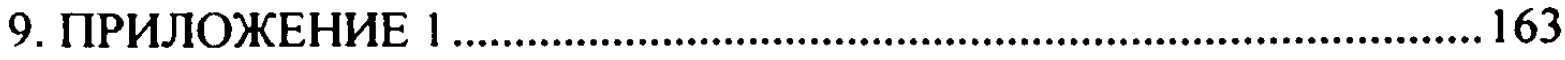

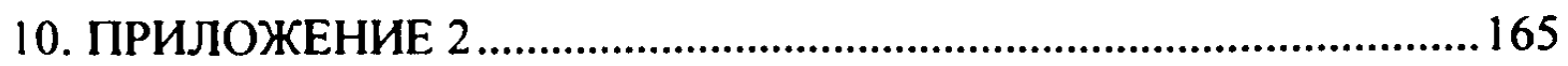

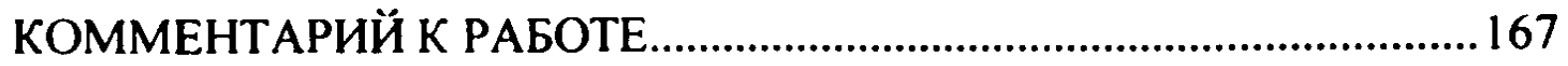




\section{ПРЕДИСЛОВИЕ}

В современном мире растёт потребность в знании иностранных языков. Практические нужды массового обучения иностранным языкам требуют оптимизации и повышения эффективности учебного процесса. С этой целью проводятся сопоставительные исследования. Первоначально они велись только на уровне языковых систем. Но со временем происходило передвижение в область экспериментальных исследований, объектом которых стал человек, в сознании которого контактируют два или более языков. Таким образом, в центр научного интереса встал сам процесс изучения языка. Проникновение в закономерности этого процесса рассматривается как единственный способ коренного улучшения преподавания иностранного языка при школьном обучении [Esser 1988]. А.А. Леонтьев отмечает в этой связи, что "обучение языку, грамоте и грамматике в школе требует для своей эффективности постоянного соотнесения структуры преподаваемого предмета с закономерностями овладения соответствующим знанием, со структурой наиболее целесообразного усвоения знаний" [Леонтьев 1965: 58].

Сопоставительные исследования проводились в основном в продуктивных видах речевой деятельности. Предполагалось, что рецептивные виды речевой деятельности формируются автоматически вследствие становления продуктивных видов. "Однако наблюдения методистов за процессом овладения речью на иностранном языке показали, что учащиеся, которых специально не обучают восприятию речи на слух, так и не приобретают аудитивных умений" [Методика 1988:104].

Осознание относительной автономности процессов восприятия обусловило повышенный интерес к проблемам восприятия иноязычной речи как со стороны практики преподавания иностранного языка, так и со стороны теории билингвизма. Уже Э. Хауген отмечал, что "развитие психологии восприятия также представляет интерес с точки зрения проблем языкового контакта, так как интерференция тесно связана с проблемой ошибочного восприятия у слушающего и у наблюдателя. Подстановка звуков и морфем часто может быть объяснена влиянием родното языка, в особенности когда речь идёт об изучающих иностранный язык взрослых" [Хауген 1972:67].

Сопоставительные исследования в области восприятия имеют также большое значение для развития теории восприятия: они позволяют обнаружить как общее, возможно, универсальное, в восприятии устной речи, так и специфическое для восприятия конкретного языка, обусловленное типологическими особенностями. В этой связи следует упомя- 
нуть роль таких работ в комплексном решении вопросов автоматического распознавания речи и даже искусственного интеллекта.

Но тем не менее восприятие иноязычной речи относится к мало изученным проблемам. Главная причина видится в том, что сам процесс восприятия недоступен прямому наблюдению. Требуется специальная экспериментальная методика, чтобы вскрыть те механизмы и закономерности, которые лежат в основе слухового восприятия.

Настоящее исследование посвящено восприятию иноязычной речи В условиях интерференции. При этом нас интересуют не собственно психологические закономерности восприятия, а те, которые диктуются характером языкового материала. В литературе отмечается, что простой перенос стратегий восприятия из родного языка в иностранный невозможен [Zawadzka 1983]. В данной работе исследуется, во-первых, вопрос о том, каким образом реализуется становление механизма восприятия на иностранном языке и, во-вторых, насколько динамика и глубина этого процесса определяется условиями усвоения языка и уровнем владения языком. Результаты экспериментов освещаются в свете теорий восприятия и билингвизма. Они дополняются практическими выводами для формирования механизма восприятия в процессе обучения языку. 


\section{1. ТЕОРЕТИЧЕСКИЕ ОСНОВЫ ИССЛЕДОВАНИЯ}

\section{1 Проблема бнлингвнзма}

\subsection{1 Определенне бнлингвнзма}

Настоящая работа исследует круг проблем, связанных с теорией билингвизма. Билингвизм (двуязычие) трактуется как практика попеременного пользования двумя языками [Вайнрайх 1972:22]. Она может перерасти в массовое двуязычие'. Изучение массового двуязычия направлено в основном на взаимодействие языковых систем в результате контакта и носит скорее социолингвистический характер - ср., например, исследование Л.А. Вербицкой, М.В. Гординой и Л.Е. Кукольщиковой о русско-украинском двуязычии [Вербицкая, Гордина, Кукольшикова 1986]. Исследование нндивидуального билингвизма обращено в первую очередь на те психологические и психолингвистические процессы, которые имеют место при попеременном употреблении двух языков. Согласно задаче работы, предметом данного исследования является индивидуальный билингвизм.

Определение билингвизма обычно связывается с уровнем владения языком. Некоторые авторы отстаивают мнение о том, что двуязычие подразумевает "владение в совершенстве употребительными, устными и письменными формами обоих литературных языков без появления интерференции в каком-нибудь уровне их структур" [Дешериев, Протченко 1972:34-35]. Однако, этот совершенный билингвизм следует рассматривать как относительно редкую, индивидуальную особенность [Juhász 1970:26]. Поэтому в современных трактовках понятия билингвизма наблюдается сознательный отход от требования совершенства. Одни исследователи исходят из такого уровня владения языком, который позволяет включаться произвольно в общение на любом из языков [Gruhn 1984; Миньяр-Белоручев 1986]. Другие авторы, учитывая неопределенность этого коммуникативного критерия, рассматривают билингвизм как континуум, крайние точки которого образуют монолингвизм, с одной стороны, и совершенное владение двумя языками, с другой [Розенцвейг 1972; Mattes, Omark 1984]. Отметим, что широкое понимание билинr-

\footnotetext{
1 Некоторыми авторами проводится терминологическая дифференииация билингвизма как индивидуального явления и двуязычия как коллективного - ср. [Исманлов 1986:110]. В настоящей работе термины двуязычие и билингвизи употребляются как синонимы.
} 
визма не является беспроблемным. По существу, оно требует детальной разработки и исследования качественных типов двуязычия.

\subsection{2 Проблема классификацин билингвизма}

Центральной проблемой в типологии билингвизма является уровень владения иностранным языком. Предпринято множество попыток осветить этот вопрос со стороны: а) тех факторов, которые оказывают влияние на формирование билингвизма и б) тех свойств, которые характеризуют билингвизм на определённом уровне.

Так, относительно сформированности навыков речевой деятельности различают рецептивный, репродуктивный и продуктивный билингвизм [Верещагин 1969а]. Однако, уровень владения языком можно определить на основе этой классификации лишь весьма обобщенно.

Ставится также вопрос о том, каким образом человек развёртывает свои мысли на иностранном языке. ${ }^{2}$ В зависимости от того, используется ли посредничество родното языка или нет, различаются опосредованный и непосредственный билингвизм [Верещагин 1969а]. Становление непосредственного билингвизма требует или определённых условий усвоения языка, или относительно высокого уровня владения иностранным языком. Но даже в последнем случае нельзя сделать более конкретные выводы о степени усвоения языка на основе данного критерия.

Известно, что, помимо индивидуальных особенностей, успешность процесса овладения вторым языком определяется и такими внешними факторами, как возраст, условия и способ овладения языком, коммуникативная значимость его [Albert, Obler 1978]. Эти факторы также используются в целях классификации типов билингвизма.

Различаются два пути усвоения языка, которые характеризуются разными психологическими закономерностями [Беляев 1965:186]. В процессе специального обучения формируется искусственный билингвизи. Как правило, в данном случае преобладает рационально-логический способ усвоения языка [там же]. Тем не менее, результат может быть двояким: складывается или дискурсивно-логическое владение языком, или интуитивное, т.е. подлинное знание языка [Нмедадзе 1979:7-8]. Думается, что эти различные способы владения языком маркируют крайние точки континуума, в котором преобладает тот или иной способ знания.

\footnotetext{
2 Распространнёный вопрос: "А на каком языке Вы думаете?" относится скорее к внутреннему проговариванию. Внутренняя речь. которая теснее всего коррелирует с мышлением. происходит вероятнее всего на универсально-предметном коде [Жинкин 1982:53].
} 
При естественном билингвизме языковая компетенция формируется без целенаправленного воздействия, в итоге речевой практики. Преобладает интуитивно-чувственное знание языка [Беляев 1965:186]. Оно оценивается как более совершенный тип владения языком [там же : 188].

Обучение иностранному языку в среде носителей этого языка приводит к сочетанию обоих типов билингвизма. При включённом обучении, которое характерно для части испытуемых (ии.) в данной работе, превалирует интуитивно-чувственный способ овладения языком.

Ясно, что данная классификация также не позволяет уточнить уровень владения языком. Можно сделать лишь весьма общие и предварительные выводы.

Наиболее общим и продуктивным критерием классификации билингвизма является характер взаимоотношения тех речевых механизмов, которые обеспечивают употребление двух языков. Уже Л.В. Щерба различал на основе этого критерия чистое и смешанное двуязычие [Щерба 1974:40]. Чистое двуязычие характеризуется отсутствием связи между двумя языковыми системами. Смешанный тип определяется тем, что второй язык усваивается через первый, и, соответственно, подвергается его влиянию. Л.В. Щерба оценивал его как наиболее распространнёный тип билингвизма [там же: 41]. Становление определённого вида двуязычия он связывал с условиями усвоения и практикой употребления языков [там же : 67-68].

Впоследствии С. Эрвин и Ч. Осгуд используют именно эти критерии для определения координативного (coordinate) и смешанного (compound) типов билингвизма [Ervin, Osgood 1954:143]. Координативный билингвизм рассматривается как результат усвоения языков в различных "культурных контекстах". Смешанный тип билингвизма развивается в одном "культурном контексте", и обе языковые системы соотносятся в рамках общей среды.

Представляется, что по существу в основе этой классификации, как у Л.В. Щербы, так и у американских учёных, лежит лексико-семантический критерий. Недаром Л.В. Щерба, приводя критерии чистого двуязычия, указывал на невозможность или крайнюю затруднённость перевода [Щерба 1974:40]. С. Эрвин и Ч. Осгуд, в свою очередь, характеризуют перевод как "cross cultural" процесс - см. [Juhász 1970, 26]. Видимо, поэтому их терминология используется в моделях билингвизма, которые восходят к характеру взаимоотношений между денотатами и соответствующими языковыми знаками - ср., например, [Виноградов 1972:1].

Но типология билингвизма должна охватывать все виды функционирования языка. Решающим критерием уровня владения языком и, сле- 
довательно, типа билингвизма должно служить наличие или отсутствие интерференции ${ }^{3}$ [Имедадзе 1979:161]. Такой подход позволяет создавать психолингвистическую типологию билингвизма. Соответствующие исследования должны быть направлены на все виды речевой деятельности ${ }^{4}$. Необходимо рассматривать их функционирование на различных ступенях овладения языком, учитывая при этом, что интерференция и билингвизм носят динамический характер [Вайнрайх 1979; Имедадзе 1979; Балиашвили 1988].

Дедуктивные, статичные определения билингвизма (ср., например [Schindler 1987]) не удовлетворяют требованиям этого подхода. Они заменяются специальными и достаточно тонкими исследованиями, которые позволяют сделать статистически обоснованные выводы. Необходимость таких исследований подчеркивается разными авторами: Hirschfeid [1983], Esser, Hirschfeld [1984], Dieling [1984], Hentschel [1986]. K работам, которые проводятся в этом русле, относится и настоящее исследование.

\subsection{3 Понятне интерференции}

В лингвистической и методической литературе термин интерференция трактуется по-разному. Мы исходим из того, что "с точки зрения индивида два языка - это два вида деятельности, В которой действуют одни и те же органы" [Вайнрайх 1979:126]. Но из психологии известно, что человек стремится переносить ранее усвоенные навыки и умения на новые действия, тем более тогда, когда они еходны. Можно иредиоложить, что перенос (transfer) наиболее типичен для тех действий, которые в высшей степени автоматизированы и поэтому, как правило, проходят неосознанно (ср. [Леонтьев 1969:143]). Это, в первую очередь, относится к артикуляции и восприятию.

Перенос рассматривается нами как общая закономерность человеческой деятельности (ср. также [Верещагин 19696; Карлинский 1980]). Он порождается сходством действий, не только материала [Šumilova 1983]. В том случае, когда явления в двух языках сходны, перенос как таковой не замечается. Это случай так называемого положительного переноса, или фачилитации [Карлинский 1980:21]. Перенос проявляется лишь тогда, когда влечёт за собой негативные последствия. Это "те случаи отклонения от норм любого из языков, которые происходят в речи двуязычных в результате того, что они знают больше языков, чем один,

\footnotetext{
${ }^{3}$ Подробно о термине см. в разделе 1.1.3.

4 Ещё в 1953 г. У. Вайнрайх иисал: "Стенень влаления следует измерять отдельно для каждого уровня - понимания. выражения и внутренней речи" [1979:132].

s Подробный обзор трактовок термина даётся в книгах Н.А. Јююбнмовой [1985; 1988].
} 
т.е. вследствие языкового контакта" [Вайнрайх 1979:22]; за этими отклонениями мы оставляем понятие интерференции. При этом интерференция включает не только результат, но и процесс взаимодействия языков. Именно последнему аспекту посвящена настоящая работа.

Таким образом, по самому определению, интерференция является двусторонним процессом. Но безусловно преобладает влияние со стороны доминирующего языка. В рамках данного исследования предполагается, что доминирующим языком является родной (немецкий) язык ии.

Интерферирующее воздействие доминантного языка рассматривается в двух планах. С одной стороны, черты родного языка переносятся в изучаемый язык, в силу чего происходят отклонения от норм второго языка. Такого рода явления наблюдаются на всех лингвистических уровнях. Это непосредственная интерференция. С другой стороны, первичность одното языка, его закреплённость может тормозить становление иных языковых структур в сознании учащегося. Это явление можно трактовать как опосредованную интерференцию. Думается, что она прежде всего характерна для позднего двуязычия. Нейрофизиологическое обоснование такого торможения на примере произношения даёт З.А. Абухамдиа [Abuhamdia 1987].

\section{2 Слуховое восприятие как многоуровневый процесс}

\subsection{1 Понятие восприятия}

Слуховое восприятие (speech perception) является частным случаем слушания (hearing) [Neisser 1967:173]. Под восприятием понимается "непосредственное отражение предмета, явления, процесса в совокупности его свойств, в его объективной целостности" [Психологический словарь 1983: 55].

С психологической точки зрения процесс восприятия включает три уровня: сенсорный, перцептивный и смысловой [там же : 59]. Сенсорный уровень обеспечивает непосредственный приём сенсорной информации. Перчептивное декодирование представляет собой "многомерную деятельность по выделению, соотнесению, интегрированию полезных, информативных признаков речевого сигнала" [Зимняя 1976: 10]. Любой акт восприятия включает осмысление. Стремление осмыслить, понять то, что человеческому сознанию даётся извне, следует рас-

\footnotetext{
' Ещё Л.В. Щерба прогнозировал смешение изучаемого языка с родным "прежде всего в области пронзношения" [Щерба 1974:62].
} 
сматривать как универсальную черту всей познавательной деятельности человека [Зимняя 1976; Hörmann 1981; Engelkamp 1983].

Осмысление может привести как к пониманию, так и к непониманию сообщения. Понимание предполагает соотнесение входного стимула с прошлым опытом индивида. Именно поэтому речевое восприятие трактуется как сложная "перцептивно-мыслительно-мнемическая деятельность" [Зимняя 1976:6].

Таким образом, слуховое восприятие требует интеллектуальной активности. Даже в тех случаях, когда на первый план выступает акустическая форма, восприятие речи не сводимо к восприятию звуков [Lindner 1981: 108].

\subsection{2 Восприятие н понимание}

Понимание следует рассмотреть как многоуровневый процесс. Оно может достичь разной глубины. В этой связи Ф. Кайнц выделяет несколько фаз понимания [Kainz 1965:52]. Это:

1. акустико-перцептивная фаза,

2. ассимилятивно-репродуктивная фаза,

3. мнемически-гностическая фаза,

4. логико-интеллектуальная фаза.

В настоящем исследовании охватывается лишь собственно языковое понимание речи, которое представлено первыми тремя фазами. При этом в центре внимания стоит опознание звуковоло образа, то, что Ф. Кайнц обозначает понятием Wortlautverständnis [там же : 359]. Действие, которое направлено на достижение этой цели, называется аудированием.

Размежёвываются восприятие звукового облика слова и понимание его значения (Wortsinnverständnis) [там же : 359]. Это важно потому, что существует принципиальная возможность правильного восприятия незнакомых слов. Воспринимая, "человек, по-видимому, сначала должен определить, с осмысленным или бессмысленным высказыванием он имеет дело, и только после этого перейти к соответствующим стратегиям восприятия" [Касевич 1987:53]. Видимо, первичной ступенью осмысления является процедура, разделяющая стимулы на знакомые и незнакомые. Насколько при этом актуализируется значение стимула, зависит, очевидно, от конкретной задачи, стоящей перед реципиентом.

\subsection{3 Восприятие и эталон}

Мы исходим из того, что в процессе опознания происходит сличение с некоторым следом, хранившимся в памяти. Этот след носит характер образца, эталона, и должен вырабатываться в речевой практике. 
Принимается существование слуховых эталонов на уровне дифференциальных признаков, фонем, сочетаний фонем, включая слоги [Джапаридзе 1985; Sendlmeier 1987a], на уровне слов [Sendlmeier 1987a] или морфем [Жинкин 1958; Zimmer 1985]. Видимо, эти единицы следует рассматривать как элементы процессуально-оперативных уровней восприятия, обеспечивающие параллельное участие ряда следов в обработке стимулов [Шехтер 1981:174]. Какие виды эталонов актуализируются в первую очередь, определяется прежде всего характером перцептивной задачи, контекстом восприятия, скоростью речи и комплексностью входного стимула [Sendlmeier 1987a], условиями восприятия [Штерн 1987a] и характером перцептивного материала [Зимняя 1976]. Таким образом, стратегии слухового восприятия отличаются гибкостью и мнопобразием; ср. [Sendlmeier 1983].

\subsection{4 Стратегия восприятия}

Эффективность человеческого восприятия обеспечивается двойным способом идентификации - поэлементным и целостным восприятием. Параллельность работы этих стратегий является гарантом восприятия стимулов [Bühler 1982:277]. Стратегии восприятия создают континуум, в котором может превалировать то целостное восприятие, то восприятие по частям [Sendlmeier 1983].

Обращаясь к вопросам целого и его частей, мы хотим подчеркнуть, что целое образа (гештальта) и его части определяют друг друга взаимно, причем существует внешнее и функциональное преимущество целого, интегрирующего части [Sendlmeier 1983; Шехтер 1981]. По отношению к процессам восприятия современная психология и психолингвистика понимают этот приоритет целого как предварительную, первичную актуализацию целостного образа, которая в случае необходимости сменяется более детальным анализом частей [Зимняя 1976; Шехтер 1981; Касевич 1987]. При этом допускается, что целостность восприятия ещё не говорит о целостности эталонов в памяти; скорее всего решение принимается на основе признаков, что однако не осознаётся воспринимающим [Шехтер 1981:229]. Можно предполагать, что в случае восприятия незнакомых единиц превалирует поэлементный способ восприятия [Галунов, Королёва, Шургая 1986; Данилов 1985; Штерн 1987].

\subsection{5 Факторы, влияющие на восприятие речн}

Известно, что восприятие зависит от условий приёма. Кроме того, результат восприятия в значительной мере определяется знанием языка и общим развитием интеллектуальных способностей. Сюда относятся 
мощность и прочность памяти, в частности - долговременной и оперативной, способность к антиципации в самом широком смысле ${ }^{7}$, развитие слуха, способность сосредотачиваться.

В ряде исследований установлено, что слуховое восприятие зависит также оr лингвистических признаков материала [Лущихина 1965; Зиндер, Штерн 1972; Федина, Рудая 1974; Штерн 1981; Sendlmeier 1987b].

Предполагается, что слова как единицы одного уровня характеризуются одинаковыми лингвистическими признаками. Каждый признак реализуется в конкретном значении - в своей градации. К примеру, слово "стать" - односложный ("длина в слогах"), двухморфемный ("длина в морфемах") глагол ("часть речи") с ударной /a/ ("ударная гласная фонема"). Как таковой, признак обычно не осознаётся аудитором.

Вслед за А.С. Штерн, лингвистические признаки трактуются как оперативные единицы в процессе восприятия, а градации факторов - как единицы принятия решения [Штерн 1987а:75]. Анализ их поведения позволяет моделировать механизм восприятия на иностранном языке.

\subsection{6 Предмет нсследования}

Центральной задачей этой работы является исследование роли лингвистических признаков в слуховом восприятии слова. Описание рассматриваемых лингвистических факторов даётся во второй главе. Исследование ведётся на уровне механизма восприятия. Он определяется весом каждого признака в общей иерархии факторов и восприятием градаций отдельных признаков (см. ниже, п. 2.3.2). Механизм восприятия описывается с помошью статистической модели процесса восприятия. В этой связи подчеркнём, что каждая модель языка и его функционирования охватывает то, "что существенно с точки зрения данной конкретной задачи" [Леонтьев 1965: 46].

Предполагается, что механизмы восприятия слова могут различаться в разных языках в зависимости от их типологических особенностей. Можно ожидать, что по мере овладения иностранным языком происходит отталкивание от механизма восприятия на родном языке и сближение с механизмом изучаемого языка. Сближение будет реализоваться как по иерархии факторов, так и по восприятию градаций факторов.

\footnotetext{
7 Антиципация понимается как механизм предвосхищения. Как правило, она реализуется на основе контекста и ситуации и предполагает не только языковое знание. но знание мира в целом. Когда в этих целях используется прежде всего языковое знание. мы употребляем понятие вероятностного прогнозирования. Таким образом. вероятностное прогнозирование рассматривается нами как частный случай антицинации.
} 
Думается, что динамика формирования иноязычного механизма восприятия обуславливается в значительной степени речевым опытом. Следовательно, продолжительное пребывание в среде носителей изучаемого языка должно привести к наибольшему сближению с механизмом восприятия носителей изучаемого языка.

Настоящее исследование направлено на проверку этих гипотез на материале восприятия русских слов немцами. В целях выявления общих черт механизма восприятия результаты работы сравниваются с данными диссертационных исследований А.С. Штерн [1981] и Т.Н. Чугаевой [1989]. Авторы этих работ исследовали восприятие русских слов русскими и английских слов американцами в той же методике, которая используется в настоящем исследовании. Учитываются также результаты дипломных работ И.А. Щербаковой [Щербакова 1984] и Е.В. Акопян [Акопян 1985] по восприятию французских и немецких слов русскими.

\section{3 Слово как объект исследования}

\subsection{1 Слово как опорный элемент сознания}

Объектом данного исследования является слово. На уровне слова начинается собственно речевое восприятие, которое предполагает осмысление стимула [Зимняя 1976:12].

Слово относится к тем психолингвистическим единствам, которые носитель языка воспринимает как цельные и естественные единицы речи [Леонтьев 1965:57]. Исследования в области человеческой памяти, её структуры и функционирования, укрепили статус слова как опорного элемента сознания [Hofmann 1982; Bock 1978; Залевская 19776, 1978, 1988].

\subsection{2 Проблема лингвнстического определения слова}

Несмотря на интуитивную вычленимость слова, его научное определение представляет значительные трудности. Сложности, которые имеет в виду А. Мартине, утверждая, что точное определение слова возможно только для конкретного языка [Martinet 1963:103], возникают не только при межъязыковом сопоставлении. Они обнаруживаются также внутри одного языка. Напомним только проблему отделяемых приставок в немецком языке.

\footnotetext{
${ }^{8}$ К глаголам с отделяемыми приставками не применим критерий внутренней цельности слова. Но все формы глагола представляют одну и ту же лексему. Видимо. на этот семантический критерий опираются носители немецкого языка. когда они определяют глагол с отлеляемой приставкой как одно слово.
} 
Трудности в определении слова обусловлены ещё и тем, что это понятие распространяется на качественно разные явления. С одной стороны, рассматриваются автосемантические слова, которые обозначают денотаты и могут функционирвать как предложения. С другой стороны, понятие слова распространяется на служебные элементы лексики, которые "как и морфологические показатели, выполняют грамматические функции актуализации полнозначимых слов, их сплочения в единое предложение, модальной характеристики высказывания и выражения межфразовых связей" [Кацнельсон 1986:9]. Отметим, что объектом данного исследования являются только автосемантические слова.

Несмотря на то, что "имеющиеся критерии выделения слова не являются универсальными" [Касевич 1977:65], большинство лингвистов при определении слова опирается на: а) позиционную и синтаксическую самостоятельность, которая отличает слово от морфемы и 6) на внутреннюю цельность структуры, что ограничивает слово от словосочетания.

\subsection{3 Слово как объект психолингвнстических исследованнй}

Одной из центральных задач психолингвистики является решение вопроса о том, каким образом языковые структуры влияют на речевое поведение человека, каким путём языковая компетенция причастна к процессам порождения и понимания речи [Helbig 1986:323]. По отношению к слову задача состоит в том, чтобы выявлять те механизмы и операции, которые лежат в основе его функционирования в речи. Эта задача должна решаться разными путями, включая "целенаправленное создание ситуаций, способных эксплицировать не поддающиеся прямому наблюдению особенности функционирования слова как опорного элемента сознания" [Залевская 1988:68].

Вместе с тем, под влиянием современных лингвистических теорий, в частности, лингвистики текста и теории речевых актов, исследование функционирования самого слова отошло на задний план. Критикуя в этой связи психолингвистику генеративной школы, Х. Херман утверждает, что анализ восприятия единиц более высокого уровня (предложения, тексты) не должен привести к пренебрежению более элементарными единицами (фонемы, слоги, слова) [Hörmann 1981:124]. 9

\footnotetext{
${ }^{9}$ Используемая в настоящем исследовании модель выделяется как раз тем. что она интегрирует разные оперативные уровни восприятия.
} 


\section{a) Теоретическое обоснование выбора слова в качестве объекта исследования}

Имеются основания предполагать, что влияние лингвистических признаков материала на восприятие и способность аудиторов использовать эту лингвистическую информацию лучше всего прослеживается на уровне слова. Это подтверждается тем фактом, что анализ восприятия слогов, слов и предложений выявил наибольшее количество сушественных лингвистических факторов для слова [Штерн 1981:14].

Понимание речевого восприятия как многоуровневого процесса подразумевает, что включение процессуально-оперативных уровней самого восприятия определяется и характером самих объектов восприятия [Зимняя 1976:12]. В восприятии изолированных звуков или слотов проявляются более элементарные перцептивные действия. Собственно речевое восприятие, которое предполагает осмысление, ещё не обнаруживается.

При восприятии предложений используется не только языковая информация. Включаются более высокие уровни умственной деятельности человека. Следовательно, успех восприятия предложения определяется не только знанием языка, но и знанием мира в целом, способностью к антиципации.

Таким образом, становится ясным, что слово является наиболее удобным объектом исследования. Но восприятие слова можно рассматривать в самых разных контекстах (ситуациях). Проведены эксперименты а) по восприятию слова в предложении, б) по восприятию изолированного слова и в) по восприятию слова, выделенного из речевого потока. По данным Г.А. Миллера, Г. Хайзе и В. Лихтена, восприятие слова ухудшается в приведённом порядке [Miller, Heise, Lichten 1951]. Вместе с тем, в исследовании Т.Н. Чугаевой [Чугаева 1989] обнаружено, что контекст как многокомпонентное явление влияет на восприятие слов противоречиво. Следовательно, роль контекста не сводима к созданию информационной избыточности, которой обычно объясняется лучшее восприятие слова в контексте [Scharpff 1987]. Но тем не менее наличие контекста уменьшает зависимость слушателя от акустико-фонетических характеристик стимула. Оно позволяет использовать логико-интеллектуальные способности обработки информации (ср. [Salasoo, Pisoni 1985]). Но поскольку задача данного исследования состоит в определении лингвистических признаков в наиболее полном объёме, контекст должен быть исключён. ${ }^{10}$

\footnotetext{
${ }^{10}$ Однако надо признавать, что при предъявлении изолированного слова контекст не сводим к нулю. Во-первых. возникает контекст списка. Во-вторых. при опознании
} 
Выделенное из отрезка речи слово опознаётся хуже изолированного стимула. Это объясняется тем, что ритмическая конфигурация и артикуляторная четкость слова изменяются под воздействием ритмической организации высказывания и темпа речи [Oakshott-Taylor 1980:85-87].

Таким образом, наиболее благоприятная ситуация для решения нашей задачи создаётся при предъявлении изолированного слова. Для автосемантических слов изолированное появление вполне вероятно в силу их семантики, ведь "слова имеют актуальную психологическую самостоятельность в том случае, когда действие проходит на предметном уровне, т.е. когда слово берётся как наименование..." [Леонтьев 1965: 123].

В этой связи нельзя обойти вопрос о значении слова вне контекста. Мы исходим из того, что "значение слова в целом складывается из совокупности его значений во всех более или менее стандартных, социально осознаваемых ситуациях с учётом степени актуальности и, следовательно, «глубины залегания» в сознании носителей языка" [Сахарный 1972: 144]. Можно ожидать, что опознание слова приводит к активизации типичных контекстов. Однако сама процедура эксперимента, скорость подачи стимулов тормозит этот процесс.

В экспериментальные программы работы включены слова в исходной, словарной форме. Она репрезентирует слово как лексему, обладая парадигматическими связями с другими словоформами. Поэтому следует оговориться, что в настоящей работе правильное восприятие слова подразумевает правильное опознание исходной словоформы.

\section{б) Прагматическое обоснование объекта исследования}

Мы уже отметили, что ситуация изолированного предъявления автосемантических слов не является чисто экспериментальным конструктом: они способны выступать в качестве одночленного предложения.

Прапматическая значимость данного объекта исследования обосновывается также особенностями усвоения языка: "... чем ниже уровень владения языком, тем более мелкие единицы текста понимаются слушающим (читающим)... Начинающие изучать язык переводят (т.е. понимают) не предложение в целом..., а отдельные слова" [Копыленко 1967: 57]. Именно линейный характер восприятия иноязычной речи приводит к известной перегрузке оперативной памяти, которую отмечает Э. Завадзка [Zawadzka 1983].

слова возможна активизация типичного для него контекста и ассоциативных связей. Это, в свою очередь, может повлиять на восприятие последующих стимулов. 
В практике преподавания иностранного языка слово имеет ключевое значение. Новое слово, которое должно быть освоено, обязательно выводится из контекста и анализируется изолированно [Günther 1986:6869]. Предполагается, что в итоге данной работы можно будет сделать выводы о перцептивной трудности русских слов определённых характеристик, что может быть учтено в практике преподавания русского языка немцам.

Настоящее исследование имеет практическое значение и в свете того, что постижение смысла текста в значительной степени определяется способностью находить в нём ключевые слова [Соколов 1968]. При этом ключевые слова представляют собой сгущённые блоки информации, которые скорее локализованы на уровне универсально-предметного кода в том виде, как его характеризует Н.И. Жинкин [Жинкин 1982].

В методическую практику преподавания иностранного языка вошло предварительное введение ключевых слов. Отмечено, что это значигельно облегчает восприятие текста на иностранном языке [Сибирский, [Штерн 1979]. Известно, что при восприятии предложений или текстов әлияние признаков словесного уровня в значительной мере подавляется ракторами более высокого порядка [Штерн 1981]. Тем не менее именно для ключевых слов наблюдается корреляция с механизмом восприятия 1золированных слов [Мурзин, Штерн 1991:100].

Таким образом, выбор слова в качестве объекта исследования обоэновывается не только теоретическими соображениями, но и практиче:кими доводами. 


\section{2. МЕТОДИКА ПРОВЕДЕНИЯ ЭКСПЕРИМЕНТОВ И СПОСОБЫ ОБРАБОТКИ ДАННЫХ}

\section{1 Экспериментальный материал}

\subsection{1 Прннципы отбора материала}

В качестве экспериментального материала на русском языке используются артикуляционные таблицы, составленные в Лаборатории экспериментальной фонетики Ленинградского государственного университета [Штерн 1977; 1984]. Русская программа включает три таблицы по 50 слов (Приложение 1), что оказалось достаточным для получения устойчивой оценки [Штерн 1981]. Составленная автором работы немецкая программа состоит из четырёх таблиц по 50 слов (Приложение 2).

Таблицы характеризуются равнотрудностью и сбалансированностью. Равнотрудность обеспечивается балансировкой таблиц между собой. Она заключается в том, что градации наиболее важных факторов представлены во всех таблицах в примерно одинаковом соотношении. Кроме того, в материале соблюдается принцип внутренней сбалансированности по ряду признаков. В идеале это означает, что любая градация одного фактора сочетается со всеми градациями других признаков. Этот принцип можно себе представить в виде разветвлённого дерева. Пропорциональная соотнесённость с другими факторами позволяет проследить, каким образом градации одного лингвистического признака влияют на восприятие слов. Исследование возможностей применения дисперсионного анализа в психолингвистических экспериментах показало, что сбалансированность материала имеет большое значение [Свиридова 1987].

Вместе с тем, точное ортогональное распределение градаций всех факторов невозможно в силу тех ограничений, которые свойственны языку. Например, в немецком языке нет двухсложных глаголов с ударением на втором слоге. Кроме глаголов sein, tun, нет односложных инфинитивов. Естественно, что эти факты накладываются на балансировку признаков.

В целях ограничения немецкого материала первичный словесный массив балансировался только по тем лингвистическим признакам, которые, по существующим предположениям, больше всего влияют на процесс восприятия. Эти факторы были определены с учётом опыта по восприятию русских слов русскими в различных условиях [Зиндер 1951; Лущихина 1965; Зиндер, Штерн 1972; Федина, Рудая 1974; Штерн 1981], 
а также по данным исследований на материале других языков [Savin 1963; Samuel, van Santen, Johnston 1982; Esser, Hirschfeld 1984].

Таким образом, внешняя и внутренняя балансировка проводилась для следующих факторов как в русских, так и в немецких словесных таблицах: "субъективная частота $\left(\mathrm{F}_{\text {суб }}\right)$ ", "часть речи", "длина в слогах", "ритмическая структура", "ударная гласная фонема"." В этом заключается однородность материала. Градации сбалансированных признаков для обоих языков представлены в габл. 1.

Факторы, которые оказались несущественными или малозначимыми при восприятии русских слов русскими, в немецких таблицах не распределялись равномерно. Это в основном такие фонетические характеристики слова, как "шумность - сонорность", "смычность - щелевость", "звонкость - глухость", "начальный звук". По техническим причинам не балансировались также факторы "консонантный козффициент" и "количество квазиомонимов", хотя они играют существенную роль в механизме восприятия русских аудиторов.

В ходе исследования возникла необходимость в рассмотрении дополнительных факторов, которые также не балансировались. Таковы "длина в морфемах", "длина в структурных элементах", "количество слого-морфемных стыков", "фортисность - ленисность". Несбалансированные признаки представлены для обеих программ в табл. 2.

Как правило, в таблицах они отражают типичные для языка статистические распределения. Например, для русского языка средний консонантный коэффициент $\mathrm{k}$ слова равен примерно $\mathrm{k}=1,4$ [Фонетика спонтанной речи 1988:210], для немецкого языка средний $\mathrm{k}$ лежит между 1,7 и 1,8 [Esser 1960:71; Никонов 1966:288]. Поэтому не удивительно, что в обеих программах большинство стимулов по данному признаку попадает в интервал $1<\mathrm{k} \leq 2$.

" В русской ирограмме внутренняя балансировка проводилась также для фактора "объективная частота $\left(\mathrm{F}_{\mathrm{ob}}\right)$ ", а внешняя (межтабличная) - для факторов "шумностьсонорность" и "звонкость-глухость". 
Таблица 1. Градачии сбалансированных лингвистических признаков

\begin{tabular}{|c|c|c|}
\hline Фактор & \multicolumn{2}{|c|}{ Программа } \\
\hline & немецкая & русская \\
\hline Объективная частота $F_{06}$ & - & $\begin{array}{l}\text { Семь интервалов по ние- } \\
\text { ходящей частоте }\end{array}$ \\
\hline Субъективная частота $F_{\text {суб }}$ & $\begin{array}{l}\text { Шесть интервалов ( }(1-6) \text { по } \\
\text { нисходящей частотности; } \\
\text { градация соответствует } \\
\text { округлению медианы до } \\
\text { целого }\end{array}$ & $\begin{array}{l}\text { См. градации в немецкой } \\
\text { программе }\end{array}$ \\
\hline Часть речи & $\begin{array}{l}\text { Существительное }(\mathrm{C}), \\
\text { прилагательное (П), } \\
\text { Глагол (Г) }\end{array}$ & $\begin{array}{l}\text { Существительное (С), } \\
\text { прилагательное (П). } \\
\text { глагол (Г), числительное } \\
\text { (Ч), местонмение (М) }\end{array}$ \\
\hline Длина в слогах & $\begin{array}{l}\text { односложные, } \\
\text { двухсложные. } \\
\text { трёхсложные, } \\
\text { четырёх- (и более ) } \\
\text { сложные слова }\end{array}$ & $\begin{array}{l}\text { См. градаиия в немецкой } \\
\text { программе }\end{array}$ \\
\hline $\begin{array}{l}\text { Ритмическая структура } \\
\text { а) "в линеечку " }\end{array}$ & 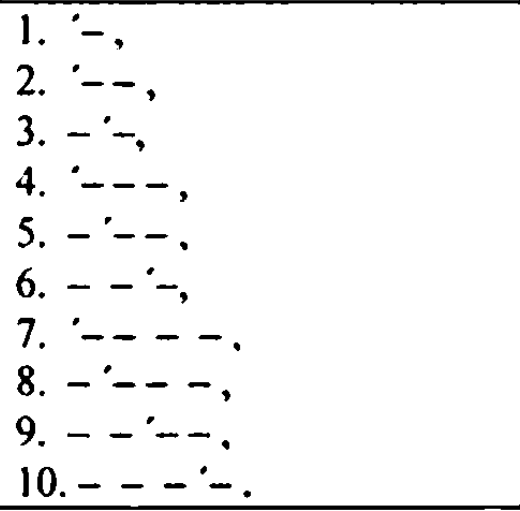 & $\begin{array}{l}\text { См. гралащия в немецкой } \\
\text { программе }\end{array}$ \\
\hline Ритмика Н - С - K & 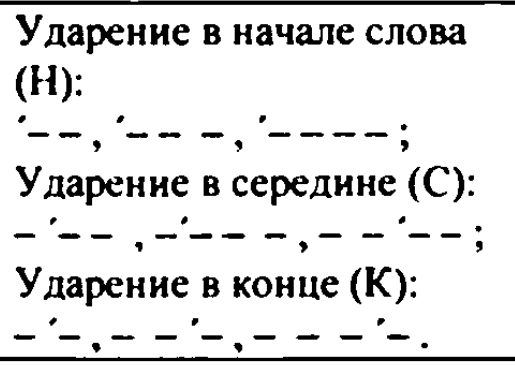 & $\begin{array}{l}\text { См. градации в немецкой } \\
\text { программе }\end{array}$ \\
\hline 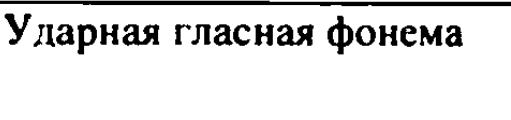 & $\begin{array}{l}\text { /i:/, /L, /u:/, /v/, /a:/, } \\
/ \mathrm{a} /, / \mathrm{ae} /\end{array}$ & $/ \mathrm{i} /, / \mathrm{y} /, / \mathrm{w}, \mathrm{e} /, \mathrm{lo} /, \mathrm{la} /$ \\
\hline
\end{tabular}


Таблича 2. Градации несбалансированных лингвистических признаков

\begin{tabular}{|c|c|c|}
\hline Фактор & Пpor & амма \\
\hline & немецкая & русская \\
\hline Количество квазиомонимов & $\begin{array}{l}{[0-1)} \\
{[1-2]} \\
(2-4] \\
(4-8] \\
(8-16]\end{array}$ & $\begin{array}{l}{[0-1)} \\
{[1-2]} \\
(2-4] \\
(4-8] \\
(8-16] \\
(16-32]\end{array}$ \\
\hline $\begin{array}{l}\text { Длина в морфемах. длина в } \\
\text { структурных элементах }\end{array}$ & $\begin{array}{l}\text { Одноморфемные. } \\
\text { двухморфемные. } \\
\text { трёхморфемные, } \\
\text { четырёхморфемные } \\
\text { слова }\end{array}$ & $\begin{array}{l}\text { См. градации в } \\
\text { немецкой программе }\end{array}$ \\
\hline $\begin{array}{l}\text { Количество слого-морфемных } \\
\text { стыков }\end{array}$ & $0,1, \geq 2$ & $0,1, \geq 2$ \\
\hline Консонантный козффициент k & $\begin{array}{l}(0-1] \\
(1-2] \\
(2-3] \\
(3-4]\end{array}$ & $\begin{array}{l}(0-1] \\
(1-2] \\
(2-3]\end{array}$ \\
\hline Количество консонансов & $0,1, \geq 2$ & $0,1, \geq 2$ \\
\hline Начальный звук & согласный, гласный & согласный, гласный \\
\hline Шумность - сонорность & $\begin{array}{l}\text { ШШумность, } \\
\text { шумность - } \\
\text { сонорность. } \\
\text { сонорность } \\
\end{array}$ & $\begin{array}{l}\text { См. в немецкой } \\
\text { программе }\end{array}$ \\
\hline Смычность - щелевость & $\begin{array}{l}\text { Смычность. } \\
\text { смычность- } \\
\text { щелевость. } \\
\text { щелевость } \\
\end{array}$ & $\begin{array}{l}\text { См. в немецкой } \\
\text { программе }\end{array}$ \\
\hline Звонкость - глухость & $\begin{array}{l}\text { Звонкость, } \\
\text { звонкость - } \\
\text { глухость, } \\
\text { глухость }\end{array}$ & $\begin{array}{l}\text { См. в немецкой } \\
\text { программе }\end{array}$ \\
\hline Фортисность - ленисность & $\begin{array}{l}\text { Фортисность, } \\
\text { фортисность - } \\
\text { ленисность. } \\
\text { ленисность }\end{array}$ & - \\
\hline Твёрдость - мягкость & - & $\begin{array}{l}\text { Гвёрдость, } \\
\text { твёрдость - } \\
\text { мягкость. } \\
\text { мягкость } \\
\end{array}$ \\
\hline
\end{tabular}




\subsection{2 Характернстнка лингвистическнх прнзнаков}

Исследуемые на материале немецких и русских слов признаки представляют несколько лингвистических уровней:

1. Уровень дифференциальньх признаков ДП:

"шумность - сонорность", "смычность - щелевость", "звонкость глухость", "фортисность - ленисность", "твёрдость - мягкость";

2. Уровень фонем:

"ударная гласная фонема", "консонантный коэффициент", "начальный звук", "количество консонансов";

3. Уровень слогов:

"длина в слогах", "количество слого-морфемных стыков";

4. Уровень морфем:

"длина в морфемах", "длина в структурных элементах", "количество слого-морфемных стыков";

5. Уровень слова:

"ритмическая структура", "количество квазиомонимов";

6. Уровень текста:

"F $F_{\text {cyo" }}$, " $F_{w 0} " 12$.

Одни признаки характеризуют слово как цельное, например, квазиомонимия и частотные параметры. Другие описывают его с точки зрения частей целого, например, "ударная гласная фонема", "характер начального звука", "количество консонансов", "консонантный коэффициент", ДП согласных, а также факторы "часть речи" и "количество слого-морфемных стыков". Но при этом надо учесть, что признаки, которые характеризуют соотношение частей, могут функционировать как комплексные признаки целого [А.Зиндер, Штерн 1986]. На наш взгляд, это имеет место у фактора "консонантный коэффициент".

Признаки "длина в слогах" и "ритмическая структура" обладают скорее двойственной природой: они могут действовать целостно и по частям. Это связано с полифункциональностью слога, который "даёт возможность, с одной стороны, дифференцировать различные речевые сегменты ..., с другой стороны, интегрировать... сегменты в единую структуру речевого высказывания" [Потапова 1986:39].

${ }^{12}$ Обоснование см. ниже, в п. 2.1.3. 


\subsection{3 Комментарнн к факторам}

При полном исследовании всех градаций признаков возник бы необозримый объём словесного материала. Это, в свою очередь, привело бы к техническим трудностям в балансировке. Поэтому в ряде случаев проводились ограничения градаций.

В русской программе мы пользуемся разбиением на градации, которые были обоснованы А.С. Штерн [1981]. Поэтому в комментариях к факторам основное внимание уделяется их описанию с точки зрения немецкого языка.

a) "Fo6", "F $\mathrm{F}_{\mathrm{c} \sigma \mathrm{C}}$

Человек упорядочивает, организует своё знание о мире. В этом процессе решающее значение имеет человеческая память. В ней существует языковой пласт - так называемый внутренний лексикон человека. Он представляет собой многоярусную систему многократно пересекающихся линейных и иерархических связей [Залевская 1980:27]. Единица лексикона является продуктом разностороннего, не только речевого опыта [Залевская 1988:68].

В структурировании внутреннего лексикона немаловажную роль играет частота встречаемости слова и речи. Её можно описывать двумя величинами, коррелирующими между собой: объективной и субъективной частотой словоупотребления.

Объективная частота $\left(\mathrm{F}_{06}\right)$ устанавливается путём подсчётов появления слов в определённом наборе текстов. Этот признак использовался при балансировке русской словесной программы. Данные об $\mathrm{F}_{\mathrm{o \sigma}}$ были взяты из Частотного словаря современного русского литературного языка под ред. Э. Штейнфельдт [1963] и разбиты на интервалы по логарифмической шкале.

Вместе с тем, при составлении словарей объективных частот принципиально анализируема лишь небольшая доля текстов, произведённых в языковом коллективе за определённое время. Точность и представительность частотных оценок зависят от отбора текстов и объёма материала. Соответственно, результаты подсчётов следует рассматривать лишь как приближение к реальным частотным характеристикам.

Другой подход установления частотных характеристик словоупотребления разработан Р.М. Фрумкиной и А.П. Василевичем [Фрумкина, Василевич 1971]. Определяется так называемая субъективная частота $\left(\mathrm{F}_{\mathrm{cy6}}\right)$. Методика непосредственно направлена на носителя языка как обладателя иерархически организованного внутреннего лексикона. При этом предполагается, что "различие в реакциях индивида на частые и редкие вербальные стимулы обусловлено иерархической организацией 
элементов речи в памяти индивида, причём эта организация находится в соответствии с вероятностями появления элементов речи в прошлом опыте индивида" [Прогноз... 1974:19]. Таким образом, привлекается речевой опыт целиком, охватывающий все виды речевой деятельности (говорение, писание, слушание, чтение). В результате получается более правдоподобная картина реальной частоты словоупотребления. Отмечается, что данные по $\mathrm{F}_{\text {суб }}$ лучше коррелируют с опознанием слов, чем оценки по $F_{\text {o6 }}$ [Фрумкина и др. 1971:73].

При подготовке программы немецких слов оказалось, что единственный общий частотный словарь немецкого языка, который нам доступен, был составлен почти 100 лет назад под редакцией Ф.В. Кэдинга [Kaeding 1898]. На этот словарь опирается X. Майер в своей работе по лингвостатистике немецкого языка [Meier 1967]. Думается, что для целого ряда слов оценки Кэдинга отражают и по сей день вероятную объективную частоту. Вместе с тем, нельзя забывать, что в основе подсчётов Кэдинга лежит письменная немецкая речь конца XIX, начала XX вB.

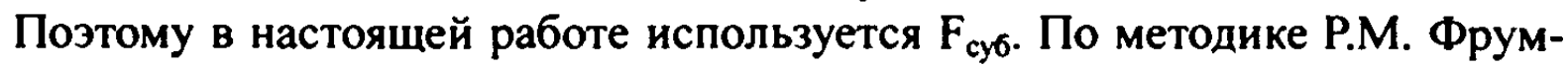
киной и А.П. Василевича [1971] был составлен словарь субъективных частот для 639 немецких слов. На основе этого материала проводилась дальнейшая балансировка факторов.

\section{6) Количество квазиомонимов}

В экспериментах по восприятию немецких слов иностранцами установлено, что в качестве замен на стимулы появляется в основном фонетически близкие слова. При этом ритмическая структура стабильна [Esser, Hirschfeld 1984:301]. Опора на фонетическую близость наблюдается также в раннем онтогенезе: вместо незнакомого слова дети повторяют фонетически близкое, им знакомое слово [Reimann 1986:93-94].

На материале русского языка роль фонетически близких слов в восприятии подверглась более детальному рассмотрению [Кукольщикова, Охарева, Штерн 1979]. Оказалось, что квазиомонимы, т.е. "слова, которые различаются всего одной фонемой при сохранении ритмической структуры и общего числа фонем", создают нижнюю границу истинного класса выбора ии. [там же : 168].

При восприятии русских слов русскими в шуме значение факгора велико. Но оно ещё возрастает при восприятии синтезированной речи [Отчёт ЛЭФ:1988].

Для того, чтобы проверить роль этого признака в механизме восприятия немецких аудиторов, количество квазиомонимов было определено для каждого слова немецкой программы. По этим данным слова объединялись в интервалы по логарифмической шкале. 


\section{в) "Длина в слогах"}

Длину слова можно описывать разными параметрами. Можно исходить из количества фонем. Но показано, что слоговая характеристика длины связана с результатом восприятия больше, чем пофонемная [Федина, Рудая 1974; Штерн 1981]. По-видимому, организующая функция слога сказывается не только в производстве, но также в восприятии речи. Коммуникативное значение слогов состоит в том, что они в состоянии обеспечить акустический контур ("Gestaltumriss") слова даже в затруднённых условиях, когда отдельные звуковые сегменты маскируются помехой [Meinhold, Stock 1982:174].

Известно, что длина слова прямым образом коррелирует с избыточностью информации. Соответственно, чем длиннее слово, тем лучше оно опознаётся [Лущихина 1965; Зиндер, Штерн 1972; Федина, Рудая 1974; Штерн 1981; Samuel, van Santen, Johnston 1982]. Думается, что это предположение подтвердится и на материале немецких слов.

\section{г) "Ритмическая структура"}

В неразрывной связи со слоговой структурой слова стоит его ритмическая организация. Особенность немецкого языка состоит в том, что место ударения в слове несёт морфологическую нагрузку. Как правило, словесное ударение падает на первый слог базисной (корневой) морфемы. Таким образом, в немецком языке наблюдается своеобразная детерминация акцентного контура морфологической структурой слова. Это позволяет сформулировать относительно простую систему акцентных правил - cp. [Wurzel 1980]. Отклонения от основного правила распространяются на чётко определённые группы слов ${ }^{13}$. В заимствованных словах морфологическая функция ударения выступает реже.

Можно предположить, что переплетение ритмики со структурой слова облегчит речевое прогнозирование. Это, в свою очередь, должно сказаться на восприятии стимулов.

\section{д) Часть речи}

При изолированном предъявлении слов анализ направлен прежде всего на роль морфологических признаков частей речи в процессе восприятия. Это тем более примечательно, что морфологические критерии в самом широком смысле слова, включая морфологическую структуру, семантические отношения между компонентами слова как результат "синтаксич-

${ }^{13}$ Они описываются в ра6оте [Wurzel 1980:100-101]. 
ности" немецкого слова признаются решающими для классификации частей речи в немецком языке [Heidolph u.a. 1981:489-490] ${ }^{14}$.

Информация о частеречной отнесённости содержится не столько в корне, сколько в служебных морфемах. При этом некоторые суффиксы характеризуют определённые части достаточно однозначно. Поэтому мы их назовём частеречными маркерами. Опознание частей речи может также зависеть от вероятности их появления в изолированной позиции, в качестве номинации.

В качестве экспериментального материала выбирались немецкие существительные, прилагательные и глаголы. Они относятся к тем полнозначным частям речи, которые, в отличие от местоимений, характеризуются надситуативностью, объективностью и семантической устойчивостью [Кацнельсон 1986:11]. Эти качества делают их особенно пригодными для изолированного предъявления.

Слова даются в исходной форме. Существительные включены в тестовые таблицы без артиклей, чтобы предотвратить установку на эту часть речи. Глаголы представлены в инфинитиве. Прилагательные приведены в краткой, неизменяемой форме. В немецком языке эта форма выступает в многочисленных синтаксических функциях, в том числе как обстоятельство образа действия ${ }^{15}$.

\section{е) "Длина в морфемах", "длина в структурных элементах"}

Вопрос о коммуникативной значимости морфем до сих пор не решён. Имекщиеся данные достаточно иротиворечивы (см. [Zimmer 1985:282]). Интерес к роли морфем в восприятии вызван ещё и тем, что в опоре на морфемы можно ожидать некоторую особенность немецкого языка, по-

i4 Деление синтаксического компонента на синтаксис слова и синтаксис предложения обосновывается тем, что и внутри слов имеются отношения иерархия и последовательности - точно так же. как в словосочетаниях и в более комплексных синтаксических обрразованиях. Наличие у слова потенциала внутренней структуры является основном аргументом в пользу его “синтаксичности» [Heidolph u.a. 1981: 131]. Особо развитые в немецком языке словообразовательные возможности словосложения привели нас $к$ гипотезе о повышенной "синтаксичности" немецкого слова по отношению к русскому; ср. исскуственное волокно - Kunstfaser; язва же.луока - Маgengeschwür. В каждом из этих примеров двум русским словам. образуюшим словосочетание. противостоит одно сложное немецкое слово.

15 Статус кратких прилагательных толкуется по-разному. Одни учёные считают, что от определённых кратких прилагательных образуется омонимичные наречия [АДмони 1972]; другие исходят из того, что немецкий язык не проводит морфологической дифференцияции между характеристикой предмета. существа и действия [Heidolph u.a. 1981:622]. Соответственно, краткие прилагательныс употребляются в различных синтаксических функциях. 
скольку он является морфологически более "прозрачным", чем, например, русский язык [Трубецкой 1987:78].

При всей структурной прозрачности немецкого языка морфологический анализ некоторых слов достаточно сложен. Трудности возникают прежде всего за счёт относительно большого числа слов с условной $^{16}$ или дефектной ${ }^{17}$ членимостью [Кубрякова 1970:119]. Они особенно характерны для пласта иноязычной лексики. Часто семантическая неразложимость заимствованных слов как будто противоречит их структуре. Кроме того, эти образования нередко выстраиваются в протяжённые ряды, охарактеризованные общностью словообразовательного форманта. Они создают объединения, которые напоминают словообразовательные гнёзда [Кубрякова 1974:50-51].

Однако в германистике отсутствуют жёсткие критерии определения заимствованных элементов. Данные у отдельных авторов колеблются от 9 до 44 суффиксов [Murjasov 1976:121]; сам же Р.3. Мурясов насчитывает 69 заимствованных суффиксов.

В. Фляйшер отстаивает синхронический подход и рекомендует подходить к каждому слову конкретно. Он выделяет пять типов заимствований [Fleischer 1976:42]:

- совершенно чужие слова, например, Oxygenium. Faible;

- вошедшие в немецкий язык слова, которые, однако, не анализируемы с точки зрения немецкого языка, например, Fakultät, obszön;

- вошедшие в немецкий язык слова, которые поддаются анализу с точки зрения немецкого языка, например, Produktion $\leftarrow$ Produkt, skandalös $\leftarrow$ Skandal;

- слова, которые являются комбинациями иноязычных элементов на основе словообразовательных моделей немецкого языка, напримep, Exminister, Kapitalist;

- слова, состоящие из сочетаний иноязычных и немецких элементов, например, superfein, Automatisierung.

Итак, опираясь на словообразование, как членимые В. Фляйшер рассматривает лишь последние три типа. Вместе с тем известно, что любая структурная регулярность материала влияет на восприятие положительно [Lazarus-Mainka 1984:117]. Как правило, регулярности возни-

\footnotetext{
16 Условная членимость принимается в тех случаях. когда структура слова формально соответствует ряду слов с живой членимостью. но семантика компонентов огличается. Характерна "несводимость значения целого к значениям его компонентов" [Кубрякова 1974:53].

17 При дефектной членимости одна из выделенных частей встречается лишь в уникальном или почти уникальном окружении [Кубрякова 1974:41].
} 
кают за счёт морфологических структур и примет, служащих "формальному опознаванию принадлежности данного слова $к$ той или иной частной группировке, начиная с таких объёмных объединений, как часть речи, и кончая небольшими, но компактными деривационными разрядами слов" [Кубрякова 1974:165]. При этом приметы имеют разную природу. Одни несомненно являются реализациями морфем. Другие представляют собой субморфемные единицы или квазиморфы, которые не могут рассматриваться как собственно строительные элементы языка. Их в дальнейшем назовём морфологическими маркерами. Предполагается, что эти элементы несут опознавательную функцию и должны быть учтены в данной работе. ${ }^{18}$

Очерченные проблемы членимости слов требуют определённого решения в рамках настоящего исследования. Поэтому вводятся два параметра, отражающие два пласта членимости: "длина в морфемах" и "длина в структурных элементах", охватывающая также маркеры.

Морфологическому членению подвергаются немецкие слова как с живой, так и с условной членимостью ${ }^{19}$. В сложных случаях выделяется максимум единиц с использованием при этом формально-структурных критериев, например, членение слова Gesundheit на Ge-sund-heit, слова Gemeinheit на Ge-mein-heit (cp. [Кубрякова 1970:118]).

В немецком языке имеется несколько рядов слов с регулярными конечными элементами, которые восходят к древним суффиксам. Частично эти сочетания появились в результате ассимиляции чужих, прежде всего латинских слов (например, Muskel - лат. muskulus). Это так называемые "корневые детерминативы" (Wurzeldeterminative) [Schmidt 1985:119]. В современном немецком языке их относят к нечленимым корням. Для нас в этой связи интересны существительные и прилагательные на $\dashv(e) r$ и $\dashv(e) l$, например, Giebel, heikel, Feier, munter. Фактор "длина в морфемах" описывает их как нечленимые корни. Вместе с тем, ter и -el могут рассматриваться также как маркеры, создающие опреде лённые ряды слов и несущие информацию об их частеречной отнесённости. Вдобавок, они имеют свои формальные корреляты в виде суффиксов -еr и -el (Köhler, Träger, Schlüssel, Hebel). Именно этой формальной корреляцией слова на $е r$ и -еl отличаются от слов с конечным $\rightarrow$ и $\rightarrow$. Последние, например, wahr, Keil, не считаются маркирован-

\footnotetext{
18 Оіметим, что к тому же выводу пришла Т.Н. Чугаева [1989] при анализе слов английского языка.

19 Здесь и далее нулевые маркеры не учитываются. Например. слово Wein рассматривается как одноморфемное образование.
} 
ными. Выделенные маркеры учитываются показателем "длина в структурных элементах".

Перейдём к рассмотрению заимствований, среди которых, как уже отмечено, распространена условная членимость. Показателем "длина в морфемах" учитываются аффиксы, которые в том же (иногда довольно абстрактном) значении повторяются в словах, членимых с точки зрения современного немецкого языка.

Проиллюстрируем это: слово Politik членится на морфемы polit-и $-i k$. По аналогии, $-i k$ выделяется и в словах Fabrik и Republik. Oстатком этого членения являются корневые квазиоморфы. Отметим ещё раз, что "главное, чем мотивируется необходимость условного членения, это структурный параллелизм некоторых образований отчётливо разложимым формам..." [Кубрякова 1974:58].

Иначе обстоит дело, например, с прилагательными на -an или -il, восходящими к латинским суффиксам -an(e)us и -ilis. Не обнаружены слова на -an или -il, которые могли бы члениться в современном немецком языке. Поэтому эти сочетания рассматриваются как маркеры и учитываются признаком "длина в структурных элементах".

Более дробному анализу по структурным элементам подвергаются также формально прозрачные слова определённых стереотипов, например, konstruktiv, destruktiv. Семантическая неразложимость этих слов находится в контрасте с их структурной прозрачностью, которая усиливается ещё тем, что слоговые и морфемные границы латинских приставок совпадают.

Итак, структурный анализ материала проводится на двух уровнях. С одной стороны, исследуется влияние "длины в морфемах" на восприятие слова. Определение градаций этого фактора осуществляется по синхроническому принципу. В центре стоит морфема как двусторонняя единица. С другой стороны, показатель "длина в структурных элементах" пытается охватить все структурные регулярности материала. Он включает так называемые маркеры, которые на синхронической основе объяснимы лишь формально-структурно. Обращение в историю этих образований показывает, что они часто восходят к древним, отчасти латинским, словообразовательным суффиксам.

\section{ж) Количество слого-морфемных стыков}

Структурная "прозрачность" немецких слов в значительной степени обусловлена тем, что слоговые границы, которые совпадают с морфемными, обозначаются в немецком языке ярче, чем в русском или англий- 
ском языках [Meinhold, Stock 1982:208]. Это происходит, потому что звонкие согласные оглушаются на стыке морфем.

Предполагается, что совпадение слого-морфемных стыков приводит к большей прозрачности структуры слова и облегчает восприятие русских слов. Но ожидается определённая дифференциация значимости признака, обусловленная структурными особенностями слов в обоих языках.

\section{3) "Ударная гласная фонема"}

В немецком языке под ударением могут выступать пятнадцать гласных монофтонгов и три дифтонга. Монофтонги противопоставены по долготе/краткости. Как правило, с этим признаком связаны напряжённость/открытость. В германистике до сих пор обсуждается вопрос о том, какая из характеристик гласных - количественная или качественная несёт основную фонологическую нагрузку. По-видимому, возможны разные ответы в зависимости от конкретных гласных [Sendlmeier 1981].

Тестовые таблицы содержат слова с ударением на тех гласных, которые в сложной немецкой вокалической системе представляют краевые точки классического фонетического треугольника. Эти "граничные" гласные противопоставлены по высоте и силе и таким образом создают максимальный контраст [Jakobson, Halle 1960:35-36]. Видимо поэтому, как отмечает П. Менцерат, они встречаются в немецком языке наиболее часто [Menzerath 1954:73].

Кроме того, в исследование включён наиболее частотный дифтонг /a/ [Meier 1967:259; Menzerath 1954:73].

1-, U-, A- звуки, а также дифтонг /а/ равномерно распределялись по таблицам и градациям. Балансировка же по дистинктивным признакам долготы / напряжённости и краткости / ненапряжённости специально не проводилась. Количественное соотношение ударных кратких и долгих гласных в материале (для /l/ - /i:/ - 1: 0,7; для /v/ - /u:/ - 1: 0,5; для $/ a /$ - /a:/ - 1: 0,8) превышает статические данные по системе немецкого языка $(\approx 1: 0,4)$ [Meinhold, Stock 1982:102]. Тенденция к количественному выравниванию градаций соответствует методическим предпосылкам работы.

\section{и) Консонантный коэффициент}

Консонантный коэффициент слова определяется по формуле $k=\mathrm{C} / \mathrm{V}$, где C - количество согласных и V - количество гласных. Соответствующий фактор исследует насколько восприятие слова зависит от соотношения в нём согласных и гласных звуков. Вопрос интересен и потому, что, с одной стороны, согласные несут бо́льшую информационную на- 
грузку, а с другой стороны, они менее помехоустойчивы, чем гласные [Bühler 1982:284; Сапожков 1963].

\section{к) Количество консонансов}

С помощью этого признака исследуется влияние сочетаний согласных на восприятие слов. К ним относятся и русские долгие согласные. Охватываются скопления согласных как внутри слогов, так и на стыке слоговых и морфемных границ.

\section{л) Начальный звук}

Особый интерес этот признак представляет с точки зрения немецкого языка, поскольку начальные гласные, с одной стороны, маркированы твёрдым приступом, а с другой стороны, по сравнению с позицией в ини ауслауте являются наиболее краткими [Вейсалов 1980:24].

\section{м) Дифференциальные признаки}

С помощью этих факторов исследуется роль дифференциальных признаков (ДП) согласных в процессе восприятия слов. Анализируемые признаки представлены в табл. 2.

Проиллюстрируем разбиение на градации на примере фактора "шумность - сонорность". В том случае, если две трети согласных в слове являются шумными или сонорными, слово относится к градациям "шумность" или "сонорность". В остальных случаях оно помещается в градацию "шумность - сонорность".

\subsection{4 Характеристика речи дикторов}

Определение градаций фонетических факторов базируется на данных слухового анализа. Поэтому вкратце охарактеризуем произношение дикTоров.

В речи русского диктора отражается полное владение литературным произношением.

Диктором, который начитывал немецкую программу, был мужчина 21 года. Его произношение можно охарактеризовать как верхненемецкое в том смысле, что он реализует нейтральный по отношению к диалектам разговорный стиль произношения ("dialektneutrale Umgangslautung"; см. [Meinhold 1973:65]) ${ }^{20}$.

Некоторые особенности этого стиля стандартного произношения не учитываются в орфоэпических справочниках, например, в Большом

20 Слуховой ананиз немецкого материала был проведён вместе с профессором Г. Майнхольдом, университет Йена. Автор глубоко благодарен ему за поддержку и помощь в раб̆оте. 
словаре немецкого произношения [Krech 1982], хотя они широко распространены и их несоблюдение часто оценивается как "сверхкорректность".

Остановимся на тех чертах произношения диктора, которые в указанном смысле не соответствуют данным словаря:

В разговорном стиле ("Umgangslautung") наблюдается тенденция к ленизации фонем /p/, /t/, /k/; cp. [Meinhold 1973:24]. В реализации диктора это касается прежде всего $/ t /$ в а) абсолютном конце слова, например в словах Frist, schlicht, feist; б) в позиции после щелевых, в частности, шипящих, перед гласными, например, в словах Institut, Struktur, streicheln. В начальных сочетаниях с фонемой $/ \int /$ ленизация /p/ и / $t /$ в ряде случаев приводит к реализации оглушённых lenes $/ \mathrm{b} /$ и $/ \mathrm{d} /$, например, в словах Spelunke, spektral, stattfinden.

Проявляется тенденция к ленизации $/ \mathrm{s} /$.

В стремлении к корректному произношению диктор допускает несколько отклонений от нормы, которые проявляются прежде всего в полном произношении сочетаний -el и -en в конце слов.

\section{2 Методика проведения зкспернментов}

\subsection{1 Запись матернала и функция помех}

Для экспериментов с русским материалом использовалась запись, сделанная в ЛЭФ ЛГУ. Запись произведена на студийном магнитофоне "Тембр 2" со скоростью v=19 мм/сек. Диктором был мужчина - носитель русского литературного произношения. Слова начитывались так, чтобы интервал между двумя стимулами составлял примерно 10 сек. После каждой таблицы следовала пауза в 30 сек.

На программу был наложен белый шум с соотношением сигнал/ шум $(\mathrm{S} / \mathrm{N})$ примерно -2 дБ. При этом белый шум выступает как помехамодель: он представляет собой самый общий и нейтральный вид внешней помехи, репрезентирующий целый ряд естественных шумовых помex [Engelke 1971]. Следует указать на то, что метод маскировки стимулов, традиционный в экспериментальной психологии, пока не нашёл широкого применения в исследованиях усвоения иностранного языка [Esser, Hirschfeld 1984:298]. Вместе с тем, белый шум, как в общем любая другая помеха, позволяет вскрыть механизмы, которые в нормальных условиях недоступны исследованию [Исенина 1969; Штерн 1981].

Таким образом, в экспериментах по восприятию русских слов немцами используется комплексная помеха. С одной стороны, это создаваемые белым шумом внешние, объективные затруднения. С другой сто- 
роны, как помеха действует сам факт восприятия второго языка, усвоение которого началось только со школы.

Убедительное доказательство того, что иностранцы более чувствительны к белому шуму, дали эксперименты Ай.Б. Гэт и Р.B. Кейт [Gat, Keith 1978]. Они показали, что в одинаковом шуме иностранцы воспринимают стимулы хуже носителей языка. В зависимости от речевого опыта, т.е., по существу, от уровня владения языком, проявляется улучшение в опознании стимулов. Но даже ии., прожившие в иноязычной среде несколько лет, воспринимают слова менее успешно, чем носители языка - в данном случае американцы. Поэтому мы предполагаем, что роль второй, субъективной помехи хоть и ослабевает по мере овладения русским языком, но она, по-видимому, не исчезает.

Этот факт должен учитываться при отборе материала для сравнения с механизмом восприятия у иностранных учащихся. Мы решили проводить сопоставление на базе примерно одинаковых данных по среднему опознанию стимулов. Соответствующие данные для носителей русского и немецкого языков были получены при соотношении $\mathrm{S} / \mathrm{N}$ около - 6 дБ.

Результаты восприятия русских слов русскими взяты из диссертационного исследования А.С. Штерн [1981]. Данные по восприятию немецких слов немцами были получены автором настоящей работы.

Немечкие словесные табличы были записаны на магнитофоне "Тембр 2" в тех же условиях, в которых проводилась запись русского материала. Слова начитывались диктором без пауз. После записи автор работы вставил паузы. Интервал для аудирования и записи каждого слова составил примерно 10 сек. На запись был наложен белый шум: в режиме Н1 -6 дБ, в режиме Н2 примерно - 12 дБ.

\subsection{2 Экспериментальная процедура}

Аудирование проводилось с воздуха. Перед экспериментом ии. были поставлены в известность о том, что они услышат слова (русские или немецкие, соответственно), на которые наложен шум. Тест проводился анонимно. Согласно устной инструкции, ии. фиксировали на подготовленных бланках то, что они восприняли, включая отрезки слов или отдельные звуки. Была предоставлена возможность отказа от ответа. Прослушивание проводилось один раз.

Участники экспериментов не обладали специальными знаниями в области фонетики. Поэтому было предложено записывать услышанное графически: русские слова - кириллицей, а немецкие слова - латинскими буквами. 
Графическая правильность ставилась выше орфографической - ср. также [Зиндер 1951]. Это ешё важно потому, что в иноязычном материале ряд слов оказался незнакомым ии., в частности, слово морж, которое многие передали как морш.

Ясно, что при графической передаче услышанного на иностранном языке могут проявляться трудности в соотнесении звук $\rightarrow$ фонема $\rightarrow$ графема - cp. [Krause, Stern 1988]. Но как показывает анализ ответов, графические ошибки отражают главным образом сложности в дифференциации и категоризации звуков, которые, в свою очередь, проявляются в русском произношении немецких учащихся (см. ниже, п. $5.1)$.

\section{3 Методы обработки данных}

Реакции ии. были перенесены на общую матрицу. На её основе проводился дальнейший анализ результатов восприятия как по характеру ответов, так и по заменам.

Далее была составлена факториальная матрица, в которой представлены значения признаков и число правильных реакций для каждого слова. Этот материал послужил основой для обработки данных методом дисперсионного анализа. Часть данных обработана на персональном компьютере A 7100. Использовалась программа DBase.

\subsection{1 Дисперснонный анали 3}

Применение дисперсионного анализа зарекомендовало себя в подобных исследованиях довольно хорошо [Штерн 1981]. Он позволяет построить статистическую модель механизма восприятия.

Частота правильного опознания слова рассматривается как качественный результативный признак, или функция. Лингвистические признаки суть аргументы этой функции. Они разбиваются на градации. Вслед за А.Н. Плохинским, слова, организованные по градациям признака, рассматриваются как выборки из разных генеральных совокупностей [Плохинский 1970:39]. Дисперсионный анализ определяет существенность/несущественность разницы между средними арифметическими правильного опознания некоторых выборок, а в данном случае - между градациями одного признака. Для этого расчитывается факториальная

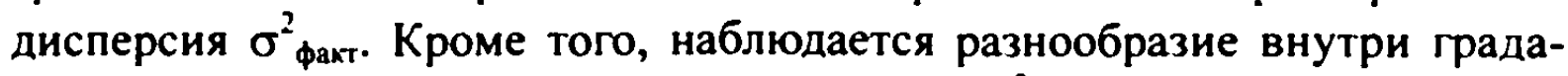
ций. Оно описывается случайной дисперсией $\sigma_{\text {ост. }}^{2}$

Общая дисперсия $\sigma_{\text {обш }}^{2}$ характеризует всё разнообразие результативного признака. Доказано, что 


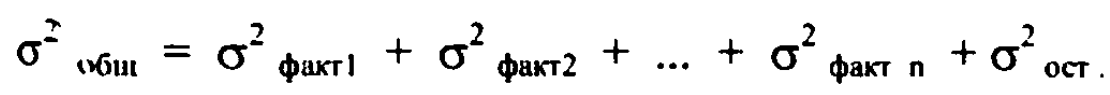

Определение доли участия каждого фактора в общей дисперсии $\sigma^{2}$ описывается показателем силы влияния $\mathrm{r}^{2}$. Он вычисляется по следующей формуле :

$$
r^{2}=\sigma_{\text {факт }}^{2} / \sigma_{06 \mathrm{III}}^{2}
$$

$\mathrm{r}^{2}$ характеризует влияние изучаемого фактора только в данной выборке. Но необходимо определить степень влияния факторов в генеральной совокупности. Это осуществляется при помощи F-критерия Фишера:

$$
F_{\text {min }}=\sigma_{\text {dakr }}^{2} / \sigma_{\text {ocr }}^{2} \text {. }
$$

Как принято в лингвистических исследованиях, достоверность гипотезы голжна быть не менее $95 \%$, т.е. вероятность ошибки Р должна

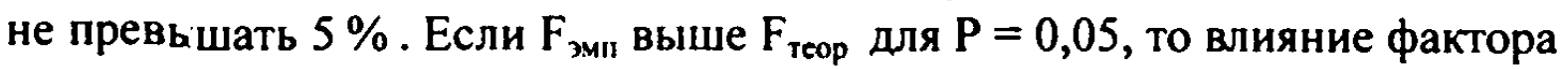
В генерільной совокупности достоверно. Подчеркнём, что в случае существьнности даже маленький показатель силы влияния $\left(r^{2}=0,01\right)$ соответствует существенной разнице по $\mathrm{t}$ - критерию Стюдента.

$\mathrm{B}$ гом случае, когда конкретное значение $\mathrm{F}_{\text {змп меньше табличного }}$ при $\mathrm{P}=0,05$, то влияние фактора не достоверно и выводы о его значении можно гринимать только для данной выборки. Но в прикладных исследования: принимается следующее решение: если существенность фактора по:-критерию не доказана, то фактор считается несущественным. Настояшее исследование придерживается прикладного подхода.

Дя обработки данных используется алгоритм качественного однофакорного дисперсионного анализа, разработанный Н.А. Плохинским [Пјохинский 1967:41].

В ряде случаев определяется относительное влияние признака. Оно вынисляется по следующей формуле:

$$
r_{i}^{2}{ }_{\text {orh }}=\left(r_{i}^{2} / \sum r_{i}^{2}\right) \cdot 100 \% \text {. }
$$

\subsection{2 Разговая корреляция}

По знач:нию и достоверности показателя силы влияния можно каждому признак приписать ранг R. Но при этом следует учесть, что разность между r соседствующих по рангу факторов может оказаться различной. Она досаточно велика для факторов высоких рангов и низка для признаков нжних рангов. 
Ранговый порядок лингвистических факторов, их иерархия, обозначается понятием механизм опоры на лингвистические признаки (в дальнейшем для краткости $M O$ ). Он характеризует значимость каждого фактора в восприятии. В МО учитываются не только существенные, но и несущественные признаки, которые, естественно, имеют последние ранги. Это позволяет проследить изменения в значимости отдельных факторов. В том случае, когда два и более факторов занимают один и тот же ранг, вычисляется средняя арифметическая тех рангов, которые они заняли бы при последовательном распределении.

В рамках настоящей работы используется коэффициент ранговой корреляции Спирмена. Он определяется по формуле:

$$
\rho=1-\left(6 \sum\left(x_{i}-y_{i}\right)^{2}\right) /\left(n\left(n^{2}-1\right)\right),
$$

где: $x_{i}-y_{i}$ - разность рангов каждого признака, $n$ - количество охваченных признаков.

Коэффициент ранговой корреляции определяет, насколько близки механизмы опоры, полученные для разных групп ии. и разных языков. Максимальная величина $\rho=+1$, минимальная $-\rho=-1$.

Трудности при межъязыковом сопоставлении МО связаны с учётом типологических особенностей языков. В частности, В русском языке согласные дифференцируются по твёрдости - мягкости. В немецком языке нет такого противопоставления с фонематической функцией. В МО немецкого языка фактору услювно принисывастся последний ранг, чтобы не терять типологически важную особенность русского языка.

Другая проблема состоит в том, что по техническим причинам некоторые факторы не представлены во всех МО. В частности, не установлена роль количества слого-морфемных стыков в восприятии русских слов русскими при соотношении $\mathrm{S} / \mathrm{N}=-6$ дБ. Значение фактора "длина в морфемах" определено при - 6 дБ, но на основе другой словесной программы [Бахарева, Краузе, Штерн 1985]. В таком случае фактор пропускается также в соотносимом механизме опоры.

\subsection{3 Анализ восприятия по градациям факторов}

Поведение градаций факторов анализируется на основе средних арифметических правильного опознания. Известно, что значения лингвистических признаков воспринимаются не одинаково [Лущихина 1965; Федина, Рудая 1974; Штерн 1981]. Можно также ожидать расхождения в опознании отдельных градаций в разных языках. Предполагается, что по мере овладения языком градации факторов воспринимаются примерно также, как носителями изучаемого языка. Описанию становления меха- 
низма восприятия на уровне градаций факторов отводится в работе значительное место. Результаты должны быть учтены при оценке степени сформированности механизма восприятия на иностранном языке.

\subsection{4 Анализ замен}

Возможны такие случаи, когда стимул не опознаётся, но отдельные признаки воспринимаются правильно. Анализ восприятия самих признаков в их конкретных значениях даёт информацию о помехоустойчивости отдельных факторов, об их стабильности в речевом восприятии. То же самое относится к градациям признаков. В этих целях определяется среднее опознание градаций признака независимо от того, как принимается стимул. В ряде случаев анализируются также так называемые "чистые" замены. Это количество тех реакций, которые обнаруживают правильное восприятие только признака, делённое на количество возможных положительных ответов по данной градации.

Кроме того, для некоторых факторов исследуются внутрифакториальные замены, т.е. замены по градациям. 


\section{3. ВОСПРИЯТИЕ НЕМЕЦКИХ СЛОВ НЕМЦАМИ}

\section{1 Актуальность нсследования}

Различные практические задачи, например, из области проверки трактов связи, аудиометрии и фониатрии, вопросы автоматического распознавания речи, а также проблемы преподавания языка, подняли интерес к вопросам слухового восприятия немецкой речи.

В литературе описаны эксперименты по восприятию отдельных фонем и слогов, предложений и текстов (например, [Bock 1978; Sendlmeier 1983, 1985, 1987a, 1987b; Lazarus-Mainka 1984; Esser, Hirschfeld 1984; Dieling 1984, 1985; Zimmer 1985]).

В итоге экспериментов определено несколько детерминантов слухового восприятия слова:

- длина в слогах [Bock 1978; Esser, Hirschfeld 1984];

- ритмическая структура [Esser, Hirschfeld 1984];

- ударная гласная фонема [Esser, Hirschfeld; Sendlmeier 1987b];

- частота встречаемости [Zimmer 1985].

Кроме того, подчёркивается важность значения вероятности структур и регулярностей языка [Lindner 1981; Lazarus-Mainka 1984]. Указывается на роль синтаксического и семантического контекста в процессе восприятия [Bock 1978; Hörmann 1981; Engelkamp 1984; Zimmer 1985]. Эти выводы подтверждают данные, полученные на материале других языков.

Но при всём многообразии рассмотренных материалов практически нет работ, в которых была бы поставлена задача более полного освещения лингвистических признаков, которые могут оказывать влияние на слуховое восприятие немецкого слова. Вместе с тем, решение этой задачи имеет большую значимость хотя бы по следующим соображениям:

1. Как уже отмечалось, практика преподавания языка должна опираться на знание закономерностей слухового восприятия речи. Это требование касается не только обучения языку людей с физическими и психическими расстройствами. Оно относится к гораздо большему кругу практических проблем, связанных с обучением иностранцев немецкому языку и с овладением иностранными языками немцами. В этом направлении имеются первые работы [Desselmann 1983a, 1983b; Dieling 1983; Hirschfeld 1983; Esser, Hirschfeld 1984]. 
В связи с такой практической установкой наблюдается расширение сопоставительных исследований в области восприятия. В этом русле ведутся первые поиски, например, на материале немецких и польских [Hentschel 1986], немецких и итальянских фонем [Grassegger 1988]. Такие исследования требуют "не лингвистической, а психо-лингвистической модели сопоставления опорного и изучаемого языков, т.е. анализа не языковых сходств и различий, а степени совпадения или расхождения операционной структуры речевой деятельности" [Леонтьев 1982:50].

2. Отказ от традиционной теории пофонемното восприятия речи привёл к новым поискам в аудиометрии. С целью объективации реакций пациентов разработаны современные аудиометрические методы. К ним относится речевая аудиометрия, которая выполняет две функции: вопервых, проверяется слух пациента; во-вторых, исследуется способность интерпретировать речевые сигналы. Таким образом, речевая аудиометрия ставит вопрос шире других подходов: слух рассматривается в естественном и основном для человека функционировании - в процессе восприятия речи. Соответственно, все виды такого тестирования направлены не столько на свойства слуха как такового, сколько на языковую компетенцию слушателя [Зиндер, Штерн 1982].

В качестве тестового материала используются слоги, слова, предложения и связанные тексты. Стимулы объединяются в списки, которые характеризуются равнотрудностью и сбалансированностью по важным лингвистическим признакам [Штерн 1984]. Предлагаемые в настоящей работе немецкие словесные таблицы могут так же, как русские артикуляционные таблицы, использоваться в качестве материала для тестирования навыков аудирования и для тренировки слуха.

3. Создание устройств автоматического распознавания речи остаётся сложнейшей технической проблемой. Опора на акустические характеристики речевых сигналов пока не давала желаемых результатов. Имеющиеся системы в состоянии распознавать лишь весьма ограниченное количество слов. Но главная проблема состоит в том, что до сих пор не удалось достичь независимости системы от определённого диктора или узкого круга говорящих. Это оценивается как основное препятствие массовому введению распознающих устройств. Решение вопроса является центральной научной задачей в ближайшее время. Оно возможно только при тесном сотрудничестве представителей тех дисциплин, которые исследуют язык и его функионирование в человеке [Kordon 1987:655].

Думается, что данные о факторах, оказывающие влияние на слуховое восприятие человека, способны дать работам по электронной обра- 
ботке речевых сигналов новые импульсы. Конечно, в этих целях необходимо большое количество дополнительных исследований, в частности, о характеристиках языковых структур в немецком языке. При этом следует рассмотреть значимые единицы языка "как определённым образом организованные целостности", а не "лишь как рамки действия фонетических закономерностей" [Зубкова 1988:341, 342].

\section{2 Характеристика экспериментов}

Эксперименты с немецким материалом проводились по вышеизложенной методике.

В основном эксперименте $(\mathrm{H} 1)$ использовалась запись с $\mathrm{S} / \mathrm{N}=$ -6 дБ. В аудировании участвовали 13 студентов в возрасте 18 лет. Эксперимент проводился в специальной звуконепроницаемой кабине. Среднее опознание слов равнялось $41 \%$. В дальнейшем мы опираемся прежде всего на результаты этого эксперимента, поскольку примерно одинаковый процент опознания позволяет соотносить их с данными по восприятию русских слов русскими и немцами.

Но в ряде случаев мы будем обращаться к данным дополнительного эксперимента $(\mathrm{H} 2)$, который был проведён в более трудных условия $\mathrm{x}$ восприятия ( $\mathrm{S} / \mathrm{N}=-10$ дБ). Это связано со следующими соображениями: во-первых, сопоставление данных $\mathrm{H} 1$ и $\mathrm{H} 2$ позволяет проследить те изменения в механизме восприятия, которые обусловлены тяжестью условий приёма. Во-вторых. прелполагается наличие параллелей межлу восприятием слов родного языка в трудных условиях приёма и восприятием иноязычных слов с недостаточным уровнем владения языком.

В эксперименте $\mathrm{H} 2$ участвовало 38 учеников 11 класса: в среднем им было 17 лет. Прослушивание проводилось в классе. Среднее опознание слов составило лишь $16 \%$.

\section{3 Описание механизмов опоры}

\subsection{1 Механизмы опоры в разных условиях восприятня}

По результатам восприятия были получены показатели силы влияния $\mathrm{r}^{2}$ и определена существенность признаков. В табл. 3 приводятся данные для обоих режимов $\mathrm{H} 1$ и $\mathrm{H} 2$. 
Тиблица 3. Значение $r^{2}$ и ранги факторов в режсияах $\mathrm{HI}$ и $\mathrm{H}_{2} 2$

\begin{tabular}{|c|c|c|c|c|}
\hline \multirow[t]{2}{*}{ Фактор } & \multicolumn{2}{|c|}{ H1 } & \multicolumn{2}{|c|}{ H2 } \\
\hline & $r^{2}$ & $\mathbf{R}$ & $\mathbf{r}^{2}$ & $\mathbf{R}$ \\
\hline$F_{\text {cyo }}$ & $\underline{0,078}$ & 1 & $\underline{0,054}$ & 1 \\
\hline $\begin{array}{l}\text { Количество } \\
\text { Квазиомонимов }\end{array}$ & $\underline{0,044}$ & 4 & $\underline{0,007}$ & 8 \\
\hline Часть речи & 0,002 & 13 & $\underline{0,003}$ & 12 \\
\hline Длина в слогах & $\underline{0,052}$ & 2 & 0,001 & 14 \\
\hline Диина в морфемах & $\underline{0,030}$ & 7 & $\underline{0,014}$ & 7 \\
\hline $\begin{array}{l}\text { Длина в структурных } \\
\text { элементах }\end{array}$ & $\underline{0,050}$ & 3 & $\underline{0,006}$ & 9 \\
\hline $\begin{array}{l}\text { Количество слого- } \\
\text { морфемных стыков }\end{array}$ & $\underline{0,042}$ & 5 & $\underline{0,028}$ & 2 \\
\hline Ритмика $\mathrm{H}-\mathrm{C}-\mathrm{K}$ & $\underline{0,004}$ & 12 & $\underline{0,006}$ & 10 \\
\hline Ударная гласная фонема & $\underline{0,034}$ & 6 & $\underline{0,022}$ & 5 \\
\hline $\begin{array}{l}\text { Консонантный } \\
\text { К)эффициент }\end{array}$ & $\underline{0,023}$ & 8 & $\underline{0,016}$ & 6 \\
\hline Количество консонансов & $\underline{0,010}$ & 10 & $\underline{0,004}$ & 11 \\
\hline Начальный звук & 0,001 & 14,5 & 0,000 & 16 \\
\hline Шумность - сонорность & 0,001 & 14,5 & $\underline{0,001}$ & 13 \\
\hline Смычность - щелевость & $\underline{0,011}$ & 9 & 0,001 & 15 \\
\hline Звонкость - глухость & 0,000 & 16 & $\underline{0,028}$ & 3 \\
\hline Фортисность- ленисность & $\underline{0,006}$ & 11 & $\underline{0,022}$ & 4 \\
\hline$\sum \mathbf{r}^{2}$ & 0,388 & & 0,213 & \\
\hline$\sum \mathbf{r}_{\text {cyau }}^{2}$ & $\underline{0,384}$ & & 0,211 & \\
\hline
\end{tabular}

Здесь и далее в таблицах подчёркнуты существенные по F-критерию факторы ( $\mathrm{P}=$ (.05). $r^{2}$ округлены на третьем месте после запятой. 
Наборы существенных факторов практически совпадают. Значит, независимо от силы помех аудиторы опираются на одинаковые лингвистические признаки материала. Но сила влияния факторов определяется условиями приёма. Так, в режиме $\mathrm{Hl}$ суммарное влияние $\sum \mathrm{r}^{2}$ всех исследованных факторов превышает почти в два раза соответствующую величину для Н2. Это объясняется тем, что в более лёгких условиях аудиторам удаётся использовать больше языковой информации. Аналогичная зависимость суммарного влияния факторов от силы помехи (уровня владения языком) получена Т.Н. Чугаевой и А.С. Штерн [Чугаева, Штерн 1989:63]. Она также обнаруживается при сопоставлении восприятия тугоухими и нормальнослышашими детьми [А.Зиндер, Штерн 1986:36].

Расхождения в блоках существенных признаков наблюдаются в основном у факторов низких рангов, оказывающих на восприятие малозначимое или вообще несущественное влияние. Кроме фактора "часть речи", это фонетические характеристики слов.

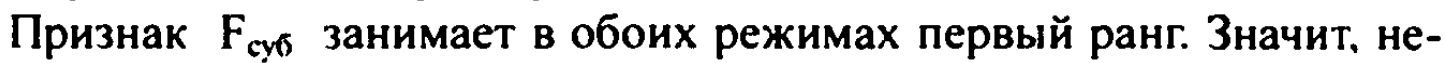
зависимо от условий приёма ии. производят опору на вероятностный прогноз стимулов в целом. Стабильностью рангов характеризуются также факторы "ударная гласная фонема", "ритмика $\mathrm{H}-\mathrm{C}-\mathrm{K}^{\text {"22 }}$, "длина в морфемах" и "часть речи".

Но тем не менее структуры иерархий $\mathrm{H} 1$ и $\mathrm{H} 2$ достаточно различны. Об этом свидетельствуют коэффициент ранговой корреляции $\rho_{11 / 42}=+0,30$. Самые заметные сдвиги ири переходе к более лёгким условиям приёма наблюдаются у факторов "количество квазиомонимов", "длина в слогах" и "длина в структурных элементах". Они указывают прежде всего на то, что усиливается целостная стратегия восприятия (см. ниже раздел 3.4).

Параллельно с улучшением условий приёма ослабевает роль признаков "звонкость - глухость" и "фортисность - ленисность", в то время как значение более тонкого фактора "смычность-щелевость" несколько растёт. Но в целом средняя для рангов ДП увеличивается в Н1 по сравнению с $\mathrm{H} 2$ на четыре ранга. Отметим в этой связи, что относительно высокие ранги ДП и достаточно низкое значение "длины в слогах" обнаружены также при восприятии слов тугоухими детьми [А.Зиндер, Штерн 1986:36]. Видимо, такое поведение факторов вообще характерно при

22 В МО учитывается только "ритмика Н - C - К". "Ритмика в линеечку" отличается от других исследованных признаков болыним количеством грапаций $(v=10)$. ПІоскольку $r^{2}$ растёт с количеством градаций [Свиридова 1987:22]. мы исключаем этот фактор из рассмотрения. 
силььно затруднённых условиях приёма. Оно говорит об усилении поэлеменітной стратегии восприятия.

Итак, сравнение ранговых порядков показывает как стабильность, так и динамичность МО в разных по тяжести условиях.

\section{3..2 Сопоставление механизмов опоры носителей немецкого и рус:ского языков}

Какі уже отмечено, в целях сравнения с русским механизмом восприятия испюльзуются в первую очередь результаты восприятия в режиме $\mathrm{Hl}$. Оніи определяются как соотносимый (в смысле среднего процента распоззнавания) немецкий механизм восприятия. МО носителей русского языка представлен в табл. 4. Коэффициент ранговой корреляции составлялет $\rho_{\mathrm{p} / \mathrm{H}}=+0,66$. Таким образом, МО ближе для двух языков в одинаковых условиях восприятия, чем для того же самого языка в разных услювиях.

Расхождения между обоими МО наблюдаются прежде всего для

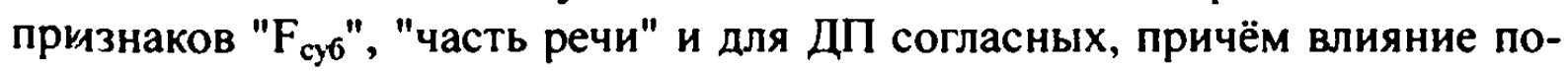
следних на восприятие слов невелико. Оказывается, что отдельные ДП согласных обладают различной перцептивной нагрузкой: если русские опщраются на "твёрдость - мягкость" и "смычность - щелевость", то для немцев ведущими признаками являются "смычность - щелевость" и "фиртисность - ленисность", а в более трудных условиях восприятия "Звонкость - глухость" и "фортисность - ленисность".

Неожиданным является тот факт, что русские аудиторы очень

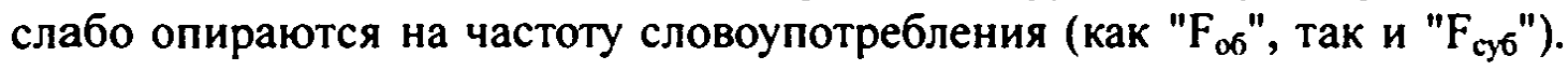
Видимо, это обусловлено тем, что аудиторами работали фонетисты. Известно, что стратегия восприятия у тренированных аудиторов направлена преимущественно на звуковой состав стимула: они склонны воспринимать пофонемно [Данилов 1985:8]. Очевидно, подавляется не только установка на смысл, но и механизм вероятностного прогнозирования. Для проверки этого предположения кажется целесообразным провести аналогичный эксперимент с наивными носителями русского языка. Но пока мы используем имеющиеся у нас данные. 
Таблица 4. Механизм опоры носителей русского языка, - 6 бБ [Штерн 1981]

\begin{tabular}{|c|c|c|}
\hline Фактор & $\mathbf{r}^{2}$ & Ранг \\
\hline$F_{\infty 6}$ & $\underline{0,012}$ & 9 \\
\hline$F_{c y 6}$ & $\underline{0.014}$ & 8 \\
\hline Количество квазиомонимов & $\underline{0,050}$ & 3 \\
\hline Длина в слогах & $\underline{0,073}$ & 1 \\
\hline Часть речи & $\underline{0,018}$ & 6 \\
\hline Ритмика $\mathrm{H}-\mathrm{C}-\mathrm{K}$ & $\underline{0,006}$ & 11 \\
\hline Ударная гласная фонема & $\underline{0,052}$ & 2 \\
\hline Консонантный козффициент & $\underline{0,028}$ & 4 \\
\hline Количество консонансов & $\underline{0,020}$ & 5 \\
\hline Шумность - сонорность & 0,000 & 13 \\
\hline Смычность - щелевость & $\underline{0,009}$ & 10 \\
\hline Звонкость - глухость & 0,000 & 13 \\
\hline Гвёрдость - мягкость & $\underline{0,017}$ & 7 \\
\hline Начальный звук & 0,000 & 13 \\
\hline$\sum r^{2}$ & 0,299 & \\
\hline$\sum r_{c y m}^{2}$ & $\underline{0,299}$ & \\
\hline
\end{tabular}

Расхождение в роли фактора "часть речи" связаны прежде всего с тем, что в русском материале исследуется восприятие шести градаций, между тем как в немецкой программе представлено только три. Но если определить степень влияния и существенность только для этих же трёх частей речи (существительное, прилагательное, глагол), то фактор "часть речи" несущественен и в русском языке $\left(r^{2}=0,000 ; F=0,104\right)$. Следовательно, для того чтобы получить более полную оценку значения фактора, необходимо включить дополнительные градации в немецкий материал.

В МО носителей немецкого языка признак "количество слого-морфемных стыков" относится к ведущим. По техническим причинам в русском языке фактор рассмотрен только при $\mathrm{S} / \mathrm{N}=0$ дБ $\left(\mathrm{r}^{2}=0,015\right)$ и поэтому не был включён в МО. Вместе с тем, сравнение имеющихся данных позволяет предположить, что признак играет большую роль в воспри- 
ятии немецкого языка. Это, очевидно, обусловлено морфонологическими особенностями немецкого языка. Как отмечает Р.К. Потапова, слоговой стык имеет в немецком языке две функции: с одной стороны, он выступает как маркер, разграничитель в фонемной цепи; с другой стороны, он является переключателем просодических признаков [Потапова 1966:406]. Возможно, информативность таких стыков связана также с "синтаксичностью" структуры немецкого слова (см. п. 2.1.3, д).

Итак, сопоставление МО носителей русского и немецкого языков показывает, что расхождения, обусловленные характером языков, распространяются на ДП согласных и, видимо, на значение фактора "количество слого-морфемных стыков". К сожалению, материал не позволяет делать выводов относительно роли признака "длина в морфемах", так как значение этого несбалансированного фактора в русском языке проверялось на базе других словесных таблиц. В целом же структура МО в обоих языках достаточно сходна.

\section{4 Анализ факторов}

Остановимся теперь на восприятии градаций признаков. Соответствующие данные должны дополнить и уточнить выводы о механизме восприятия немцев, сделанные на базе дисперсионного анализа.

\subsection{1 Субъективная частота $F_{\text {cy6 }}$}

Фактор "F су6" оказывается наиболее существенным лингвистическим признаком в обоих экспериментальных условиях (табл. 3). Ведущая роль частоты словоупотребления - в данном случае "Fo6" - отмечена гакже при восприятии английских слов американцами. В МО носителей русского языка фактор действует слабее; о причинах написано выше в п. 3.3.2.

Если сопоставить относительное влияние фактора, то оказывается, что доля признака в режиме $\mathrm{Hl}(17,6 \%)$ несколько ниже, чем в $\mathrm{H} 2$ $(22,5 \%)$. Можно предположить, что как и в русском языке опора на вероятностный механизм несколько усиливается в более трудных условиях. Более ярко эта тенденция проявляется при восприятии английских слов русскими и американцами: доля признака " $\mathrm{F}_{\mathrm{o6}}$ " в $\sum \mathrm{r}^{2}$ составляет 9,6 $\%$ для носителей английского языка, $34,0 \%$ для сильной группы русских аудиторов и $45,6 \%$ для русских аудиторов со слабым знанием английского языка [Чугаева, Штерн 1989:63]. Результаты по восприятию русских слов немцами, однако, не подтверждают эту гипотезу (см. ниже, п. $4.3,5.3)$. 
При анализе восприятия слов по градациям найдена чёткая связь между частотной характерикой слов и опознанием. Так же, как в русском языке, слово опознаётся тем лучше, чем оно частотнее (рис. 1, 2).

Рис. 1. Зависиность восприятия немецких слов немцами от признака "субъективная частота $\left(F_{\text {суб }}\right)$ " $(H 1, H 2)$

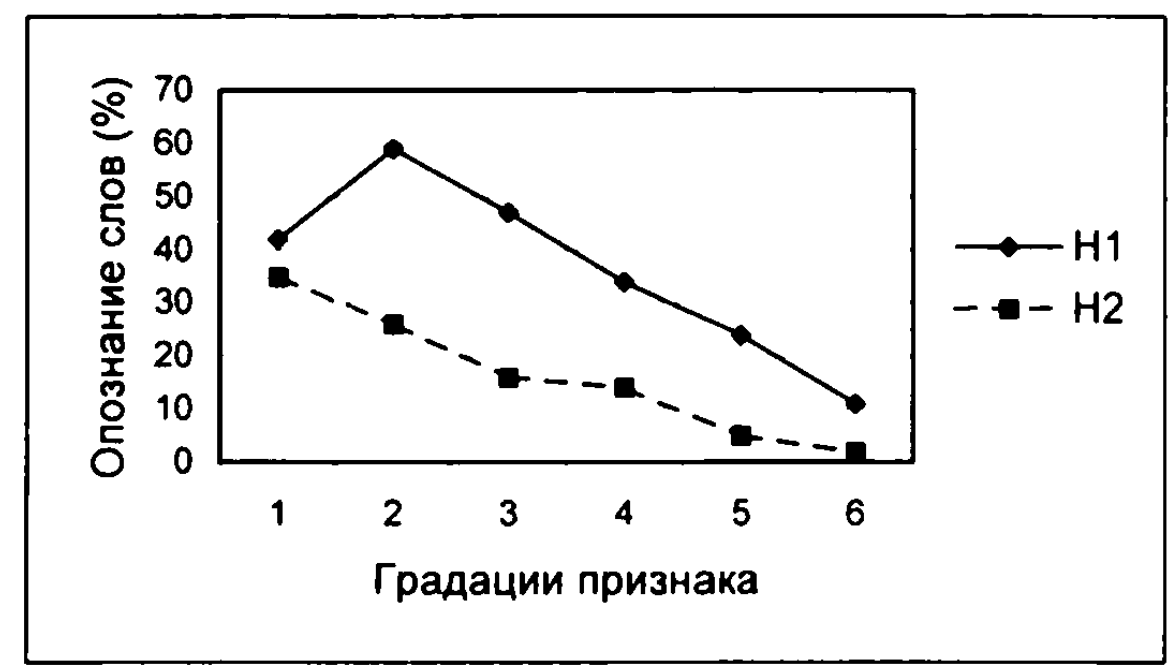

Pис. 2. Зависимость восприятия русских слов русскими (P) от признака "субъективная частота $\left(F_{c, 6}\right)$ "

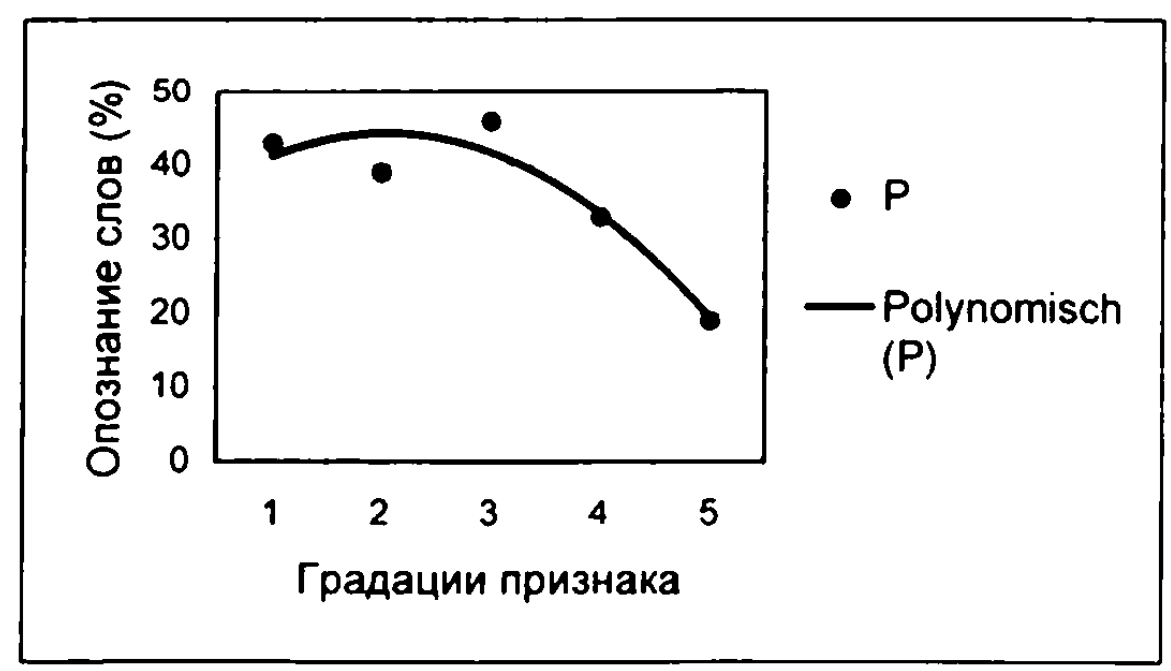

Интересно однако, что в эксперименте Нl слова с высшими частотными оценками опознаются хуже слов последующей градации. Возможно, здесь проявляется "конкуренция" факторов. Известно, что более частотные слова в среднем короче менее частотных, а короткие слова, в свою очередь, обладают бо́льшим количеством квазиомонимов [Savin 
1963; Венцов и др. 1985]. Это может привести к ухудшению опознания высокочастотных слов.

\subsection{2 Количество квазномонимов}

Признак "количество квазиомонимов" характеризует слово как целое. Поэтому примечательно, что влияние фактора в более лёгком режиме HI значительно выше, чем в режиме Н2 (табл. 3). Это говорит об усилении целостной стратегии восприятия в более лёгких условиях приёма.

Так же, как в русском языке, поведение градаций фактора показывает чёткую обратно-пропорциональную зависимость между числом квазиомонимов и опознанием слов (рис. 3,4 ).

Известно, что количество квазиомонимов обратно пропорционально длине слова [Кукольщикова, Охарева, Штерн 1979:167]. Сопряжённость факторов находит своё отражение и в нашем материале. ${ }^{23}$ Если $81 \%$ односложных слов имеет от 3 до 8 квазиомонимов, то среди двухсложных это лишь $23 \%$, а среди трёхсложных только $3 \%$. Четырёхсложные слова фактически не обладают квазиомонимами.

Соответственно, результаты восприятия можно было бы трактовать с точки зрения длины в слогах. Но представляется более адекватной другая стратегия: наличие квазиомонимов заставляет аудитора выбирать среди множества похожих эталонов. Вероятность сличения с правильным эталоном тем выше, чем меньше элементов входят в это множество [Кукольщикова, Охарева, Штерн 1979:167]. По-видимому, маскировка стимулов и отсутствие контекста усиливают этот поисковый механизм.

Рис. 3. Зависимость восприятия немечких слов от признака "количество квазиомонимов" (HI, H2)

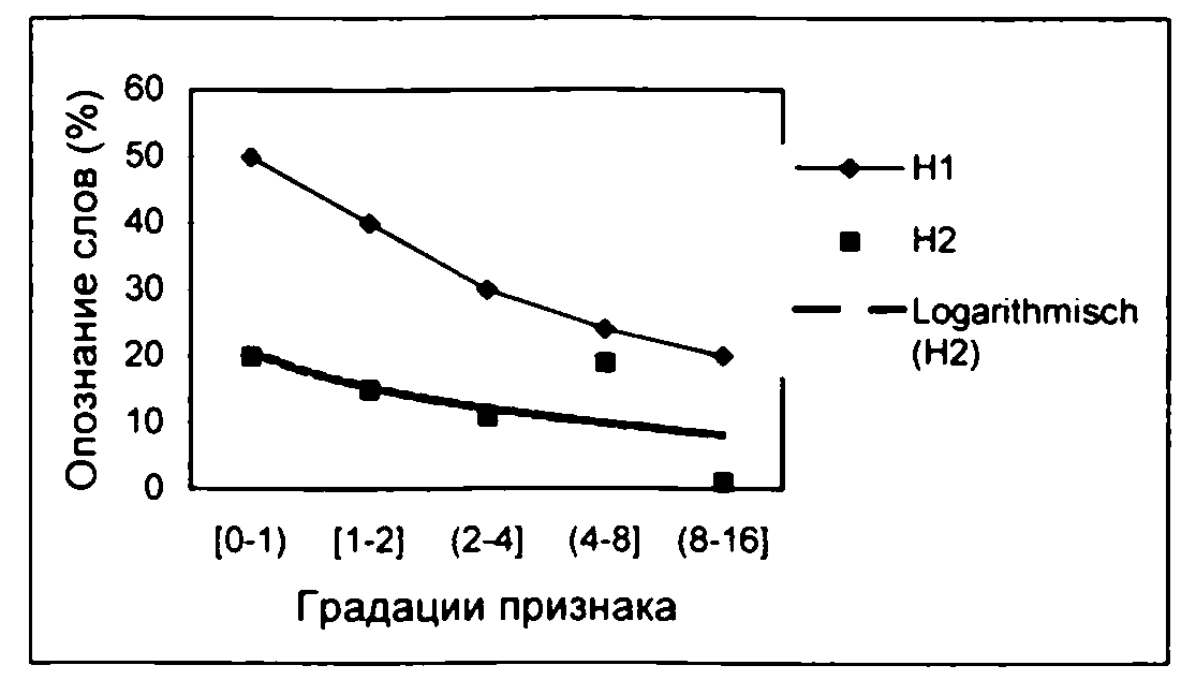

${ }^{23}$ І Іапомним. что фактор не подвергался балансировке. 
Рис. 4. Зависимость восприятия русских слов от признака "количество квазиомонимов" (P)

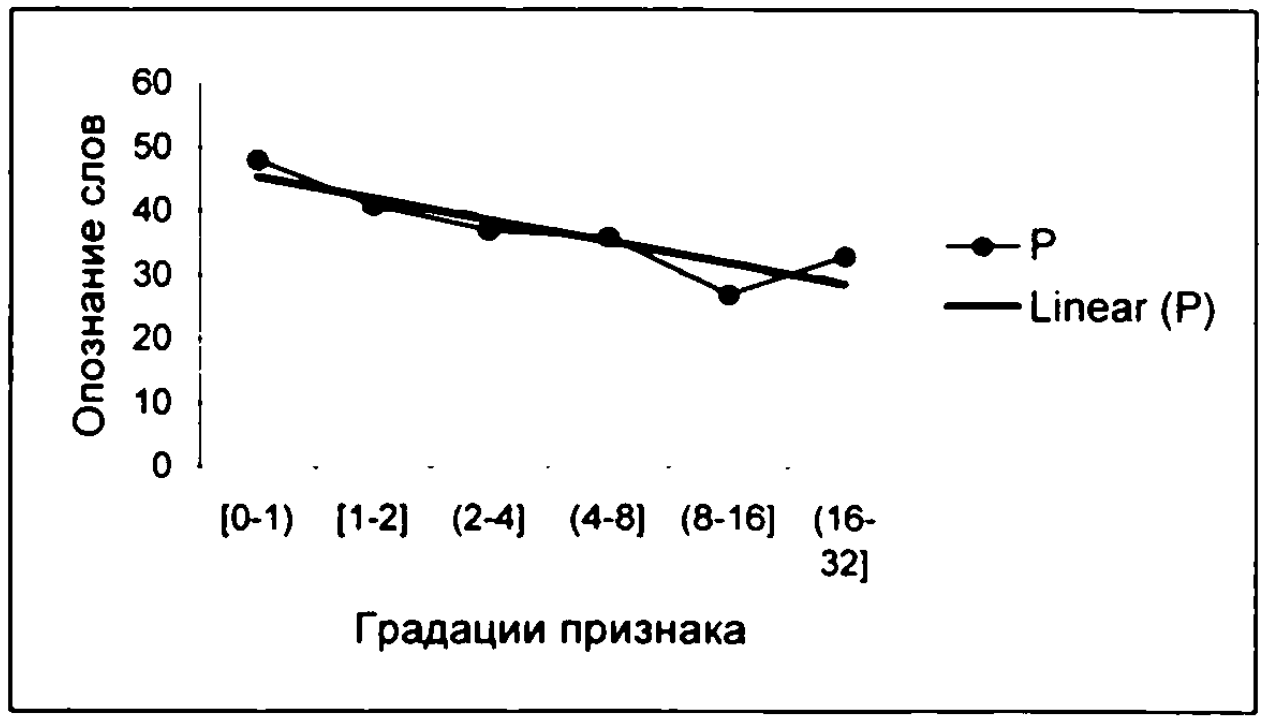

\subsection{3 Длина в слогах}

В МO (H1) признак "длина в слогах" занимает второе по значимости место (табл. 3). Высокий ранг фактора согласуется с данными по восприятию русских и английских слов.

Кривые зависимости отражают чёткую корреляцию между длиной слова и сго опознанием: чем цлиннее слово, тем больше оно содержит информации и, соответственно, тем лучше оно опознаётся как в немецком языке, так и в русском (рис. 5, 6). Это ещё одно подтверждение того, что функциональная нагрузка слога распространяется не только на производство, но и на восприятие речи. Зависимость восприятия от длины свидетельствует также о том, что в данном случае признак действует скорее щелостно.

Другая ситуация наблюдается в более трудном режиме Н2, в котором фактор несуществен: опознание слов фактически не зависит от их длины (рис. 5); лишь для четырёхсложных слов намечается некоторое улучшение восприятия (рис. 5). Очевидно, в тяжёлых условиях приёма стимулы воспринимаются скорее поэлементно (послогово). 
Рис. 5. Зависимость восприятия немецких слов от признака "длина в слогах" (HI, H2)

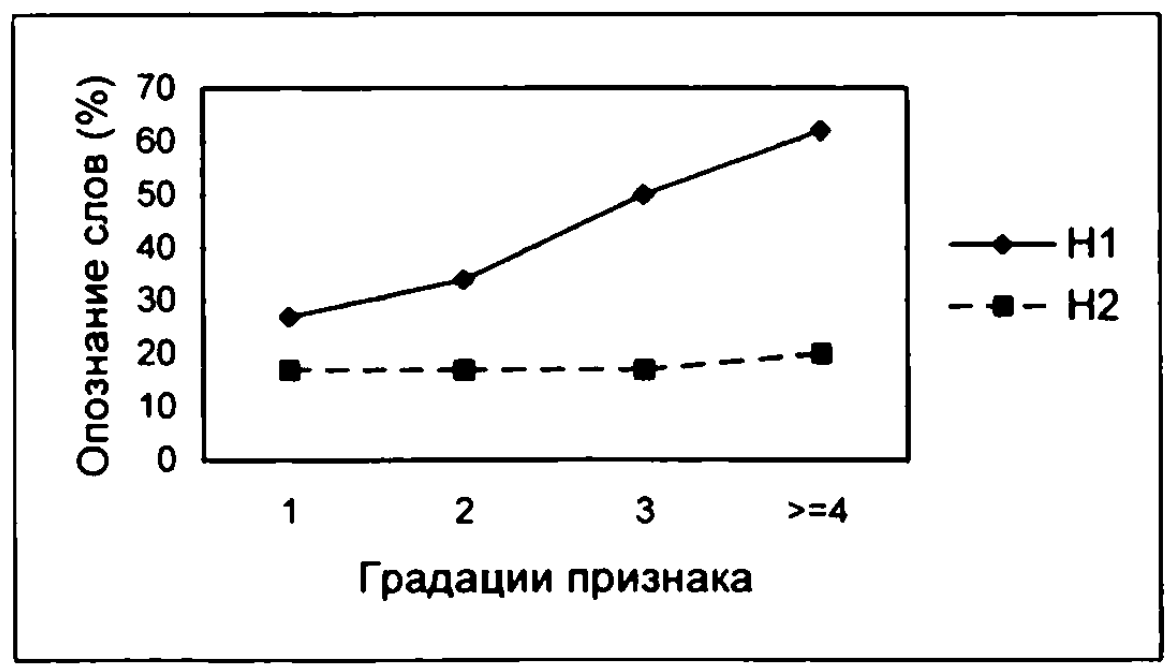

Рис. 6. Зависимость восприятия русских слов от признака "длина в слогах" (P)

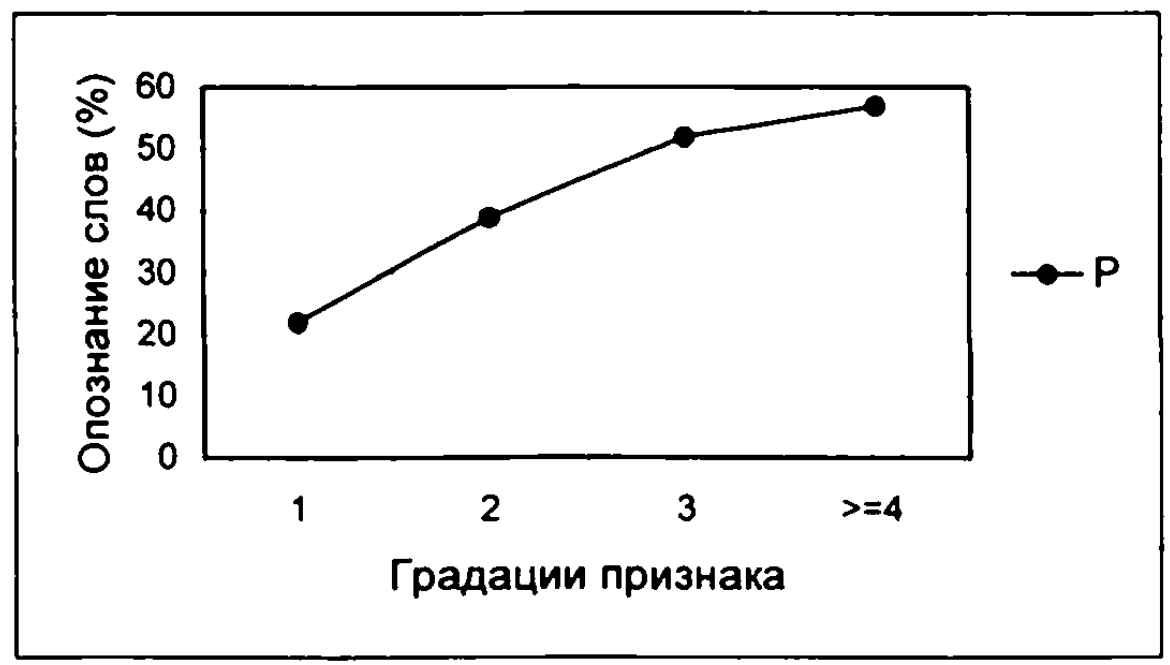

В реакциях ии. наблюдается высокая стабильность признака. Замены производятся в первую очередь внутри градаций (табл. 5):

Таблича 5. Замены по градачияи признака "длина в слогах" (\%)

\begin{tabular}{|c|ccccc|}
\hline Реакция & 1 & 2 & 3 & 4 & Стимул \\
\hline 1 & 40 & 2 & 0 & 0 & \\
2 & 2 & 35 & 4 & 0 & \\
3 & 0 & 1 & 18 & 2 & \\
4 & 0 & 0 & 1 & 14 & \\
\cline { 2 - 7 } & 67 & 70 & 67 & 76 & Опознание признака \\
\hline
\end{tabular}




\subsection{4 Ритмическая структура}

Влияние ритмической структуры слова на восприятие исследуется для двух сопряженных параметров: первый ("в линеечку") описывает все возможные ритмические структуры; второй ("ритмика $\mathrm{H}-\mathrm{C}-\mathrm{K}^{\prime}$ ) обобщает структурные типы. Как уже отмечено, в МО учитывается лишь последний параметр.

Фактор "ритмика $\mathrm{H}-\mathrm{C}-\mathrm{K}$ " хоть и достоверен в обоих режимах, но его влияние в МО невелико (табл. 3). То же самое можно сказать о поведении фактора в МО носителей русского языка (табл. 4). Таким образом, при всей стабильности признака [Лущихина 1965:1]; Отчёт ЛЭФ 1973:65; Esser, Hirschfeld 1984:301], в нашей модели фактор не относится к ведущим.

Перейдём к анализу ритмической организации "в линеечку" (рис. $7,8)$. Как видно из рис. 7 , в обоих режимах поведение градаций фактора отражает одинаковые тенденции:

1. Хореические структуры опознаются лучше ямбических. То же самое происходит в русском языке. Это может объясняться тем, что хорей появляется раньше в онтогенезе как в немецком [Гоер, Гоер 1927], так и в русском языке [Швачкин 1948], и поэтому он более устойчив к помехам [Штерн 1987a:73].

2. Среди трёхсложных слов лучше всего воспринимаются слова с ударением на втором слоге. С одной стороны, серединноударные слова характеризуются оптимальным распределением интенсивности в слове, а с другой стороны, анализ показывает, что примерно половина этих слов имеет структуру префикс - ударный корень - сvффикс. При этом в нашем материале морфемные швы обязательно проходят между префиксом и корнем и частично между корнем и суффиксом. Слова этого типа воспринимаются почти на треть лучше, чем менее чётко структуированные слова (60\%: $43 \%$ ). Очевидно, данная морфолого-ритмическая структура слова характеризуется наиболее зффективным распределением информации. Высокое опознание приставок позволяет предугадать те морфологические модели, которые могут лежать в основе стимулов. Тем самым для аудиторов уже сужается класс выбора. Ударением выделяется слог, полностью или частично тождественный корню и восполняющий "белое пятно" в ожидаемой модели или моделях. Последний слог даёт скорее уточняюшую информацию. ${ }^{24}$ Он в ряде случаев помимо суффикса содержит элементы корня.

\footnotetext{
24 Характер неправильных словесных реакций на стимулы структуры префикс ю)ариыи корень - суффикс подтверждает предположение о том. что в сознании ии.
} 
Данные для трёхсложных слов русского языка противоречивы [Штерн, Элькин 1989:149]. Но серединноударные слова не воспринимаются лучше других слов.

3. Что касается четырёхсложных слов, то здесь слова с ударением на втором слоге воспринимаются лучше других.

Pис. 7. Восприятие немецких слов в зависиности от признака "ритиическая структура" (HI, H2)

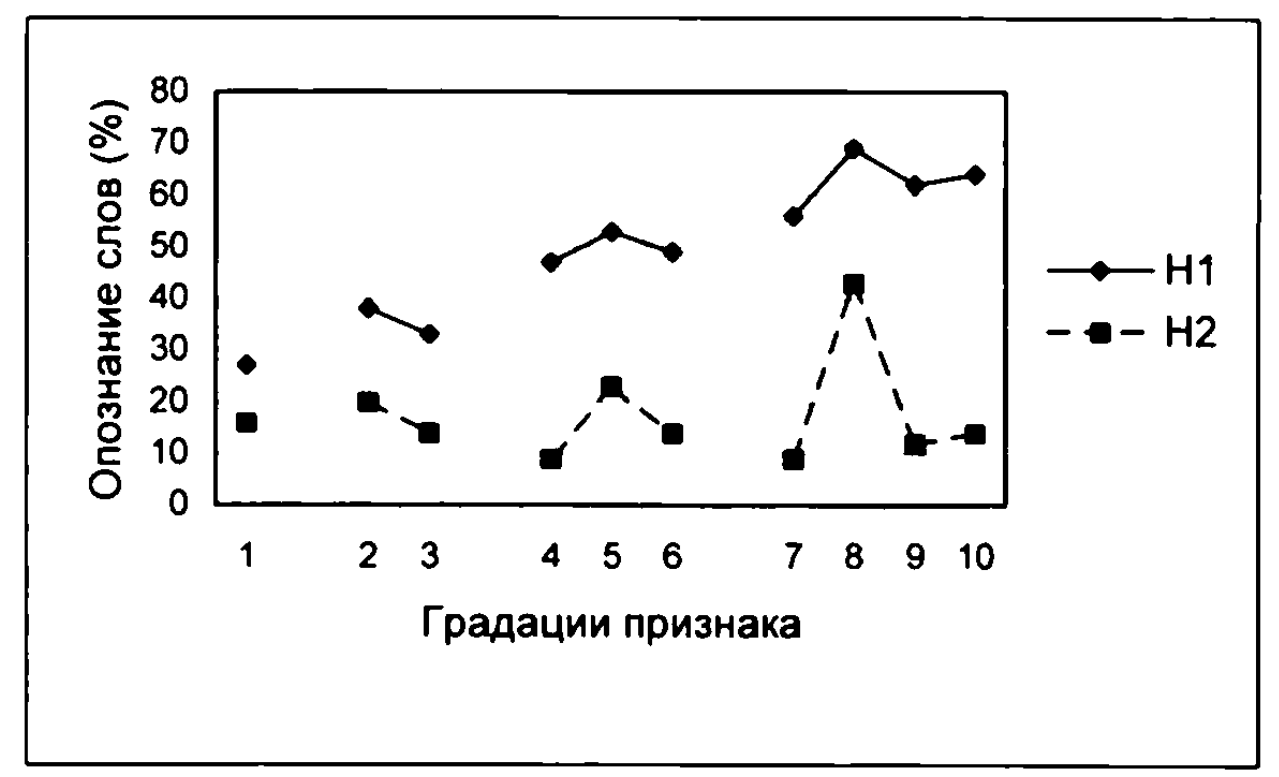

Подтверждается, что морфологическая структура префикс - ударный корень - суффикс (-cуффикс), которая реализуется в словах данной градации, является наиболее благоприятной для восприятия слов в немецком языке. Сравнение с данными носителей русского языка, которые лучше всего воспринимают четырёхсложные слова с ударением в начале или конце слова, позволяют считать этот факт особенностью немецкого языка. Частично она отражается также при восприятии немецких слов русскими учащимися [Акопян 1985]. Думается, что те ии., которые воспринимают данную структуру так, как немцы, обладают развитой способ-ностью к речевому прогнозированию в изучаемом языке.

При восприятии четырёхсложных русских слов русскими наблюдается $\cup$-образное распределение результатов восприятия: лучше всего опознаются слова с начальным и конечным ударением.

активизируются структурные модели. Тенденции таковы: а) морфологическая структура воспрннимается правильно, а заменяется корень или 6) приставка и корень опознаются. а (последний) суффикс заменяется другим. тоже вполне вероятным.

${ }^{25}$ Для расшифровки гратаций см. табл. 1. 
Рис. 8. Восприятие русских слов в зависимости от признака "ритиическая структура" $(P)^{26}$

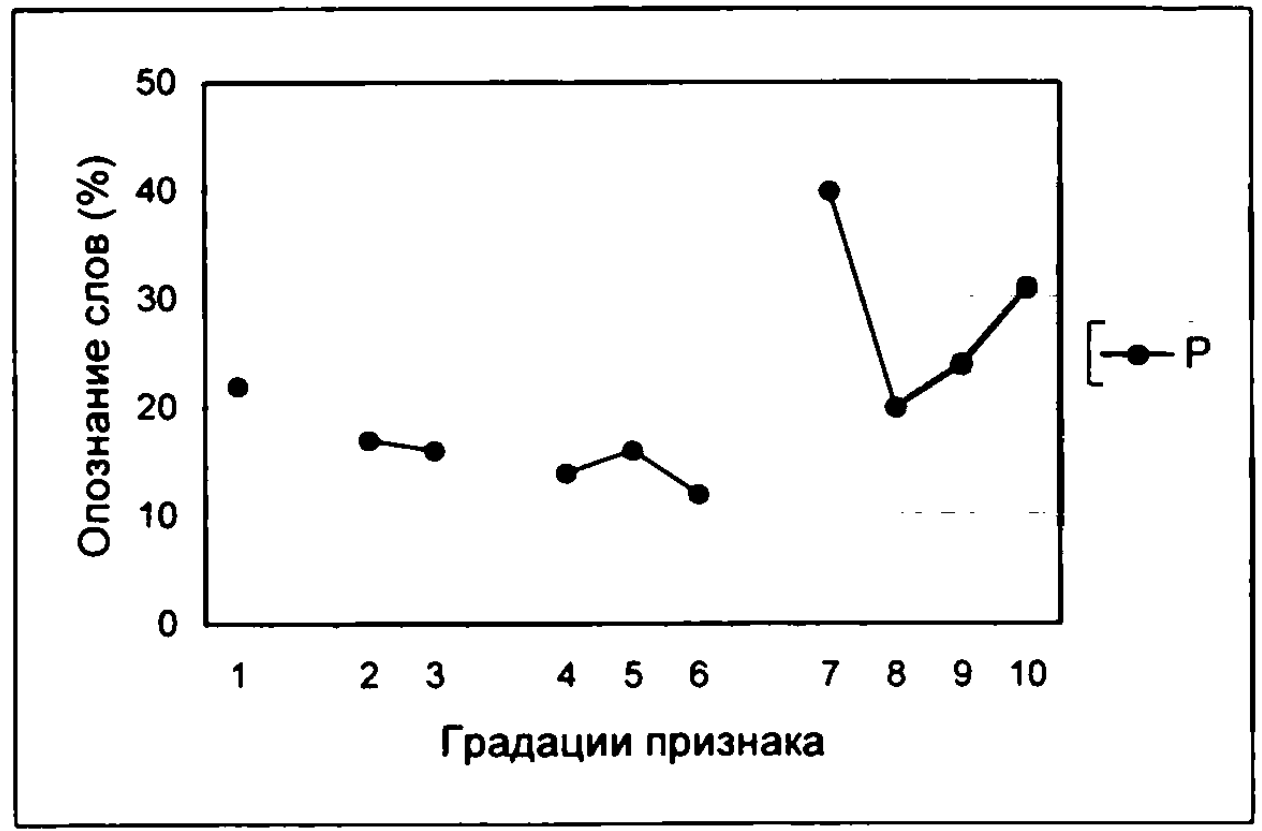

Анализ градаций фактора "ритмика $\mathrm{H}-\mathrm{C}-\mathrm{K}$ " выявляет следующую картину: слова с ударением в середине слова воспринимаются лучше слов с начальным и конечным ударным слогом (рис. 9). Такая тенденция обнаруживается также в восприятии немецких слов русскими аудиторами [Акопян 1985].

Рис. 9. Восприятие немецких слов в зависимости от места ударения $H-C-K(H I, H 2)$

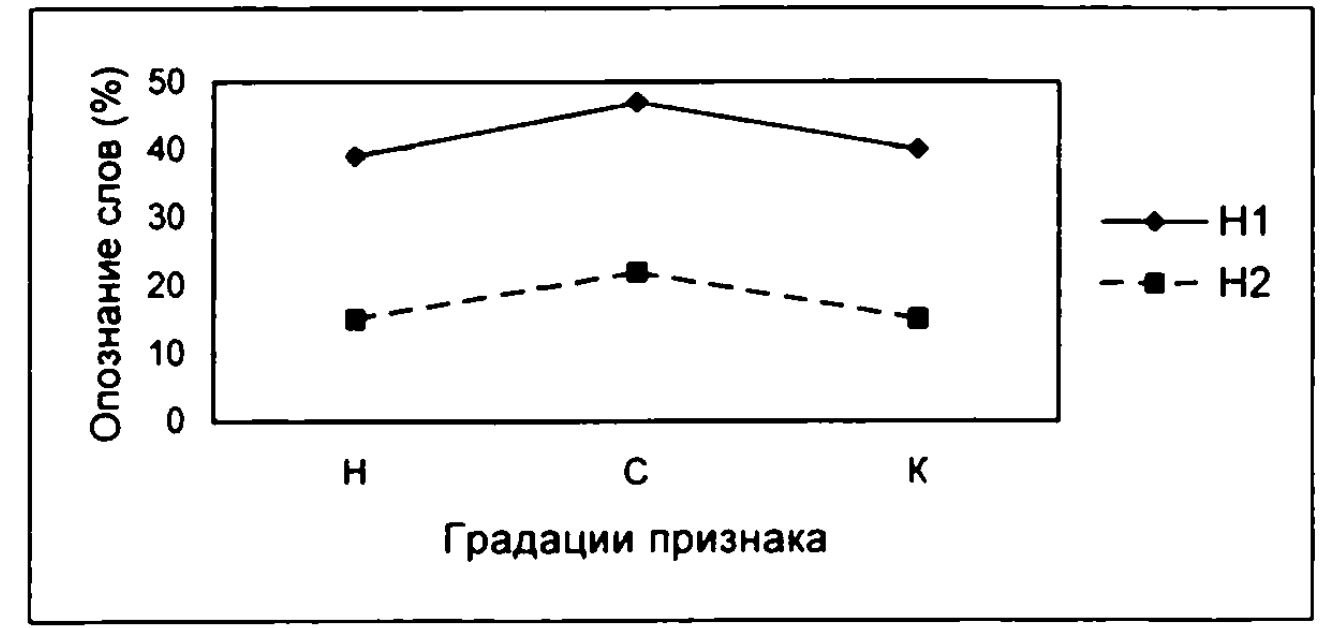

26 Дия расшифровки гралаиий см. табл. 1. 
В русском языке опознание слов ухудшается по мере передвижения ударения к концу (рис. 10).

Рис. 10. Восприятие русских слов в зависимости от места ударения $H-C-K(P)$

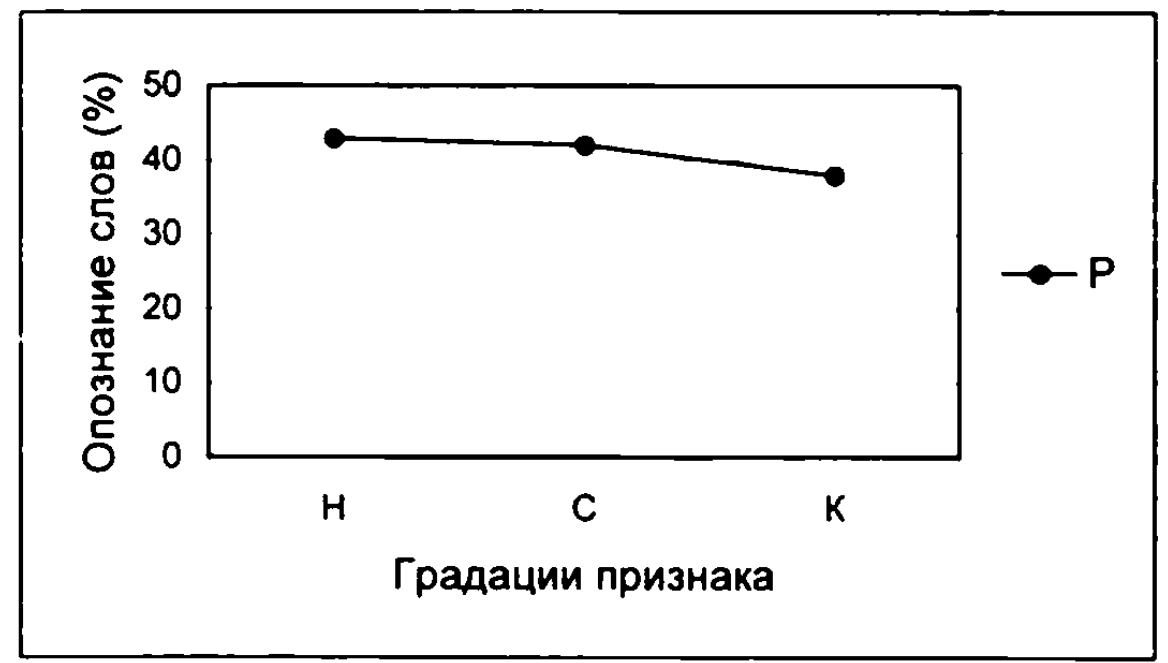

\subsection{5 Факторы морфемного уровня}

Признак "часть речи" занимает в МО носителей немецкого языка неожиданно низкий ранг (табл. 3). Данные дисперсионного анализа позволяют заключить, что в исследованных условиях приёма принадлежность к определённой части речи практически не оказывает влияния на восприятие изолированных немецких слов (существительных, прилагательных, глаголов). То же самое обнаружено на материале английского языка.

В МО русских роль фактора выше. Но мы уже указывали на то, что дифференциация результатов восприятия реализуется за счёт числительных и местоимений, а существительные, прилагательные и глаголы воспринимаются примерно одинаково (рис. 11). Это согласуется с данными других исследований [Лущихина 1965; Федина, Рудая 1974].

Вывод о несущественности фактора в немецком материале подтверждается при анализе опознания градаций признака (рис. 12). Дифференциация результатов восприятия практически отсутствует. Из этого следует, что ни одна из исследованных частей речи не маркирована настолько однозначно, чтобы она опознавалась лучше других. (Напомним, что речь идёт об изолированном слове.)

Однако более точный анализ словесной программы показывает различия в степени маркированности градаций. Если все глаголы маркированы суффиксом -en, то среди существительных и прилагательных мы имеем морфологически маркированные (например, Gemeinsamkeit, Er- 
ziehung, behutsam, klumpig), так и не маркированные слова ${ }^{27}$ (например, Fall, gut, zart).

На материале прилагательных установлено, что слова с частеречным маркером опознаются в два раза лучше (50\%), чем немаркированные слова (25\%). Соответственно, можно было ожидать, что глаголы будут восприниматься лучше других частей речи. Но этого не происходит прежде всего потому, что появление глаголов в качестве номинации менее вероятно, чем появление существительных. Кроме того, показатель -е высоко омонимичен [Адмони 1970:197]. Он встречается также у существительных и прилагательных. Об этом свидетельствуют реакции ии., в которых вместо глаголов приводятся существительные на -en (например, Rücken, Wissen вместо ticken). ${ }^{28}$

Рис. 11. Восприятие русских слов в зависимости от частеречной принадлежности $(P)$

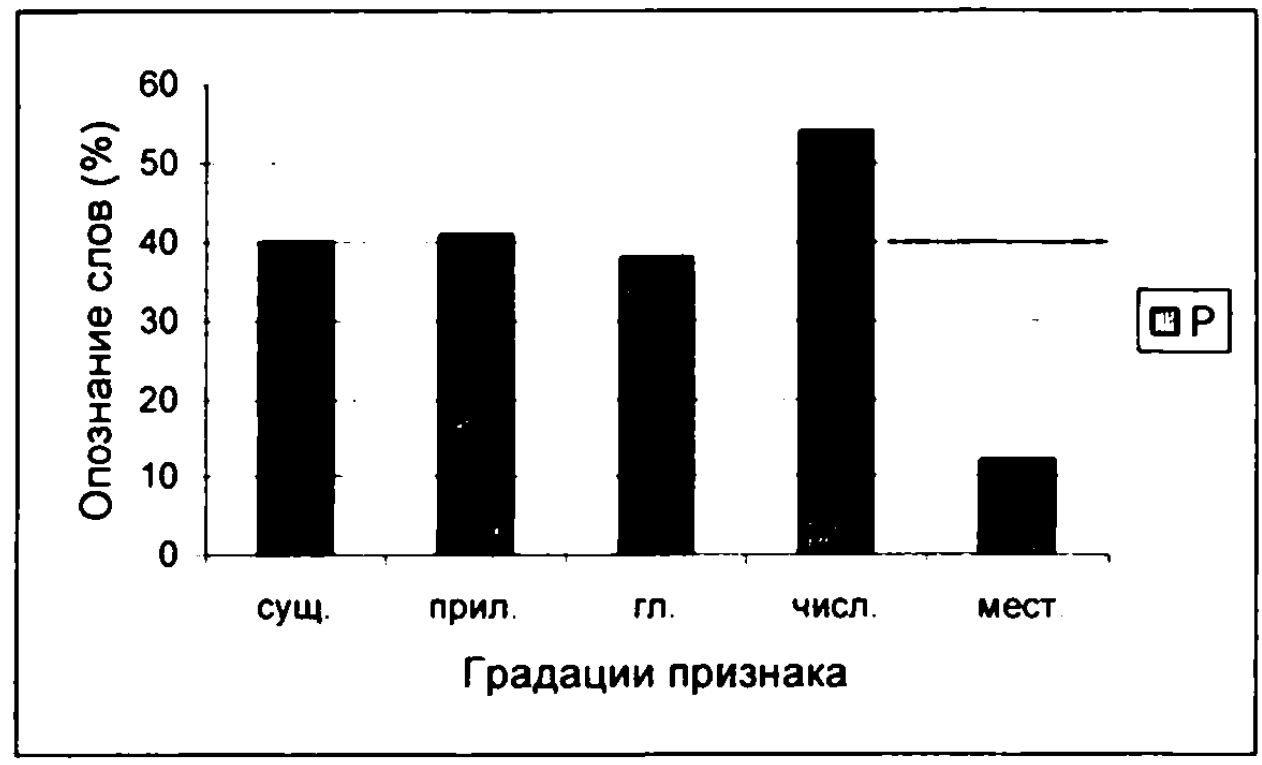

Тем не менее анализ всех реакций показывает, что принадлежность к определённой части речи ("частеречность") воспринимается лучше конкретных стимулов (рис. 12). Безусловно, это в первую очередь связано с влиянием тех морфем, которые маркируют части речи. Служебные морфемы наиболее помехоустойчивы: они воспринимаются как минимум на треть лучше, чем стимулы в целом (см. ниже).

${ }^{27}$ Слова с нулевым маркером назовём немаркированными.

28 Разнородный статус еп в морфологической системе здесь не рассматривается. Нас интересует только роль этих омонимичных элементов в процессе восприятия. 


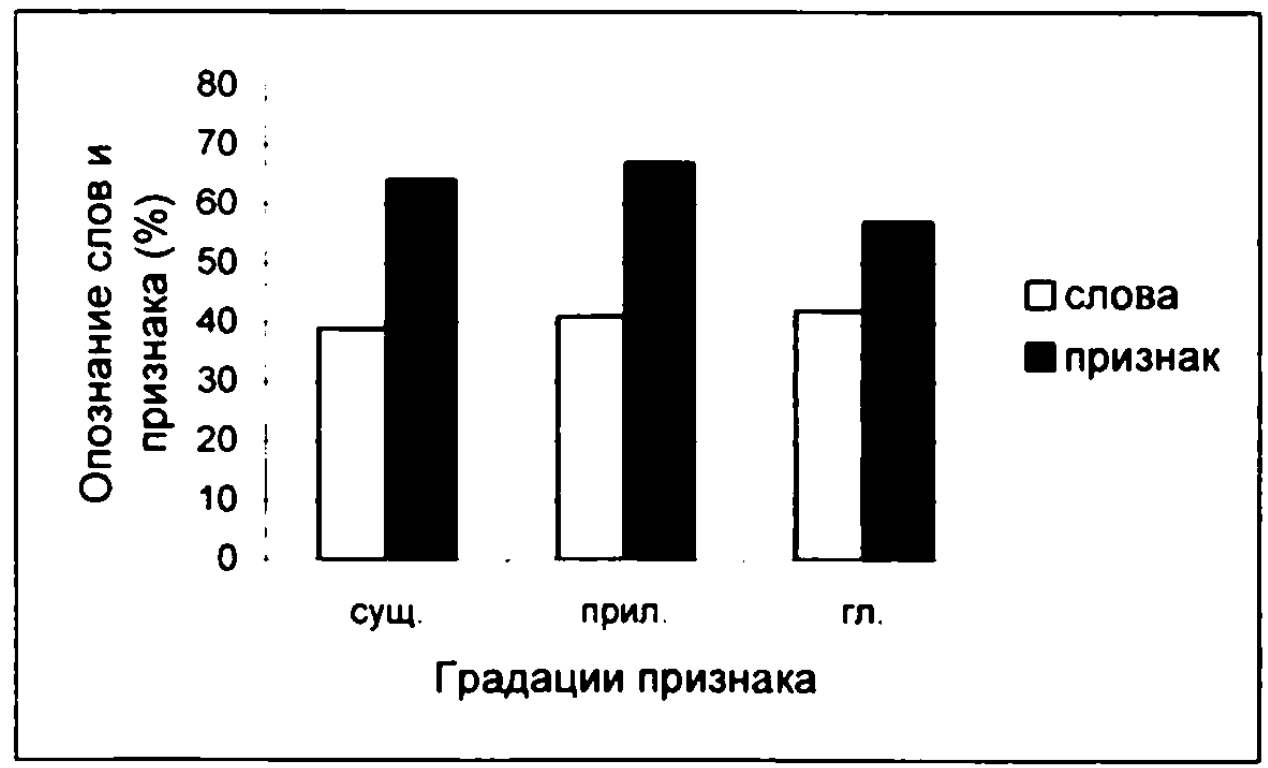

Обнаруживаются следующие типичные замены:

существительное

прилагательное глагол

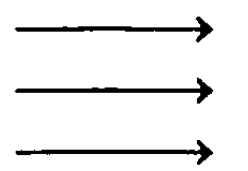

существительное, существительное, глагол.

Таким образом, наиболее стабильными частями речи в изолированной позиции являются сушествительное и глагол. Поэтому можно заключить, что суффикс -еп маркирует всё-таки в первую очередь глагол.

Активная замена частей речи на существительные отражает стремление к номинализации при отсутствии контекста. Кроме того, нулевой маркер особенно характерен для немецких существительных [Адмони 1970:197]. Можно ожидать, что немаркированные слова скорее всего заменяются на существительные. На примере прилагательных установлено, что это действительно так: замены немаркированных прилагательных на существительные встречаются в 2 раза чаще, чем на прилагательные. Реакции на маркированные прилагательные содержат существительные и прилагательные в равной мере.

Количественный анализ "чистых замен" приводит к выводу, что неточно услышанное слово с гораздо большей вероятностью заменяется на существительное, нежели на прилагательное или глагол. Такая же последовательность обнаруживается при восприятии русских слов русскими. Она отражает одинаковую в обоих языках вероятность появления этих частей речи в номинативной функции.

Сам факт опоры на морфемы подтверждается при анализе фактора "длина в морфемах". Он относится к значимым признакам и занимает в 
обоих режимах $\mathrm{H} 1$ и $\mathrm{H} 2$ стабильный средний ранг (табл. 3). Признак коррелирует с "длиной в слогах". Так, большинство односложных немецких слов состоит из одной морфемы, двухсложные делятся в основном на две морфемы и т.д. Соответственно, факторы "длина в слогах" и "длина в морфемах" следует рассмотреть как варианты длины. Из рис. 5 и 13 видно, что в режиме $\mathrm{Hl}$ слово опознаётся тем лучше, чем больше оно содержит морфем и слогов.

Рис. 13. Зависимость восприятия немечких слов от признака "длина в морфемах" (Hl, H2)

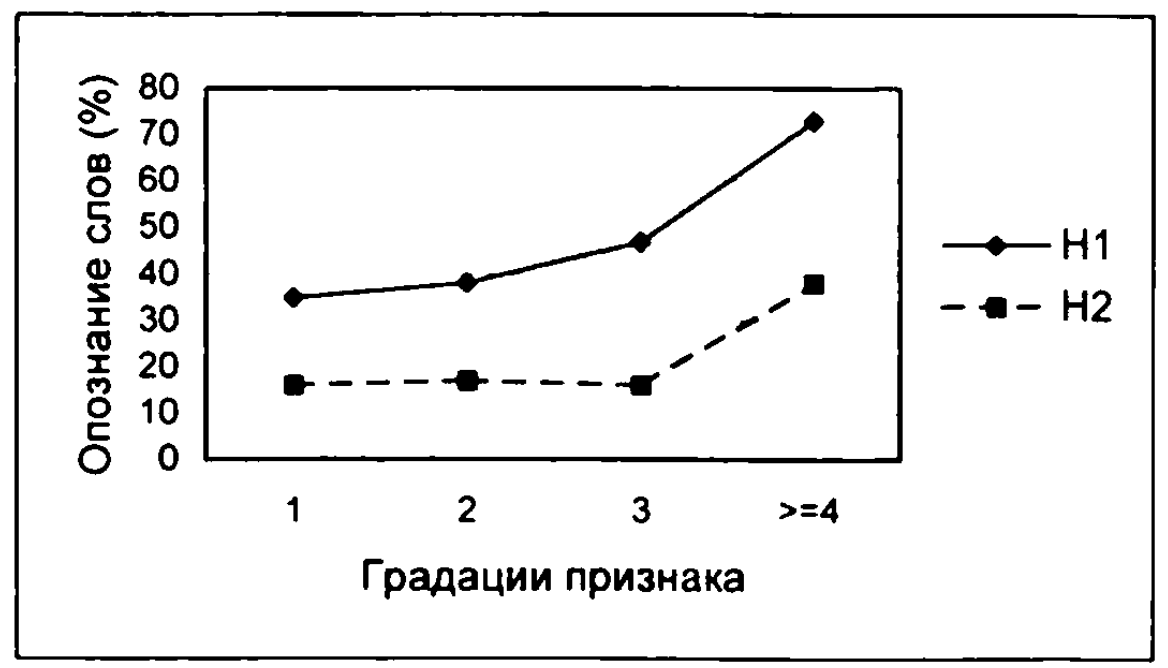

Но сопоставлснис признаков вскрывает любонытный факт, подтверждающий относительную автономность морфем и слогов при восприятии (табл. 3). По сравнению с $\mathrm{H} 2$ в условиях $\mathrm{Hl}$ "длина в слогах" резко увеличивает своё значение, между тем как относительное влияние "длины в морфемах" фактически не изменяется. Поэтому можно предположить, что в крайне трудных условиях приёма усиливается поиск значииых элементов (морфем).

Рассмотрим в этой связи параметр "длина в структурных элементах". Напомним, что в основе выделения этого признака лежит мысль о том, что любая структурная регулярность в материале облегчает восприятие - не только морфемы, но и маркеры, характеризующиеся обычно довольно абстрактным значением (ср. п. 2.1.3).

Особенность фактора состоит в том, что он больше, чем чисто морфемное членение, коррелирует с "длиной в слогах". Этим и объясняется значительный рост влияния фактора при переходе к более лёгким условиям приёма (табл. 3).

Отметим, что слова-корни, обладающие маркером, воспринимаются почти в 2 раза лучше, чем слова-корни без маркеров. Психологиче- 
ская реальность маркеров прослеживается также в заменах ${ }^{29}$, например, вместо Giebel ии. дают ӥbel, Bibel, Jubel, Zwiebel, Siegel, nobel, тоже содержащие -el. На основании этих ответов можно предположить, что -el скорее приписывается существительному, чем прилагательному.

Таким образом результаты приводят к выводу о том, что аудиторы опираются как на морфемы, так и на маркеры. Это тем более примечательно, что при опросе лингвисты и методисты (носители языка) не отмечали функциональной нагрузки маркеров. Тем не менее мы предполагаем, что носители языка независимо от своей лингвистической подготовки используют маркеры в случае аудирования.

Остановимся более подробно на опознании отдельных видов морфем (табл. 6).

Таблица 6. Опознание типов морфем (\%) в режимах $\mathrm{HI}$ и H2

\begin{tabular}{|c|c|c|c|}
\hline Режим & Префикс & Корень & Суффикс \\
\hline $\mathrm{H} 1$ & 72 & 41 & 62 \\
\hline $\mathrm{H} 2$ & 35 & 17 & 32 \\
\hline
\end{tabular}

Лучше всего воспринимаются приставки, затем следуют суффиксы и корни. Эти данные опровергают преположение о том, что служебные морфемы идентифицируются хуже посткорневых [Lüdtke 1988:440]. Сходная картина наблюдается при восприятии русских слов русскими. Правда, там первое место занимают окончания [Бахарева, Краузе, Штерн 1985:184].

Хорошее восприятие служебных морфем объясняется тем, что они образуют конечное множество меньшего объёма. Следовательно, выбор ограничен. Это приводит к их высокой частоте. Кроме того, место их появления в слове предопределено, что облегчает вероятностное прогнозирование.

Дополнительный расчёт показывает, что в немецком материале $97 \%$ приставок находится или в ударной, или в первой предударной позиции. Что касается суффиксов, то только $17 \%$ из них ударные, причём это в основном заимствованные морфемы. Судя по всему, постударная позиция, которая типична для немецких суффиксов, менее благоприятна для опознания морфем.

Вероятностный прогноз труднее всего реализуется для корней. Показательно, что корни в производных словах воспринимаются более ус-

29 Правда. характер ответов ии. не позволял исследовать психологическую значимость каждого из маркеров. Для этого необходима специальная работа. 
пешно (47\%), чем слова-корни (34\%). В этих результатах проявляется роль морфологического контекста.

С морфологическим уровнем связан также фактор "количество слого-морфемных стыков" . Как видно из табл. 3, в МО немцев этот признак относится к наиболее значимым. Его роль особенно велика в крайне трудном режиме Н2. Эгот факт является ещё одним доказательством того, что в трудных условиях восприятия усиливается стратегия восприятия по частям.

Отметим, что для большинства слов $(71 \%)$ не обнаружено совпадения слоговых и морфемных границ. $23 \%$ слов имеет один совпадающий стык и лишь у $6 \%$ слов встречается два и больше слого-морфемных стыков.

Анализ градаций показывает следующее (рис. 14): в режиме $\mathrm{Hl}$ наблюдается постепенное повышение правильных реакций, в то время как в режиме $\mathrm{H} 2$ значительное улучшение в опознании замечено только для слов с двумя и более слого-морфемными границами.

Напомним, что роль этого фактора в восприятии русских слов русскими исследовалась при $\mathrm{S} / \mathrm{N}=0$ дБ. Слова воспринимаются тем лучше, чем больше они содержат совпадающих стыков (рис. 15). Но вес фактоpa $\left(r_{p}^{2}=0,015\right)$ ниже, чем в немецком языке $\left(r^{2}{ }_{11}=0,042, r_{H 2}^{2}=0,028\right)$. Можно сделать вывод о том, что в русском языке этот фактор менее значим, чем в немецком. Но в целом структурная прозрачность слов действует положительно на их восприятие как в немецком, так и в русском языке.

Рис. 14. Восприятие немечких слов в зависиности от количества слого-морфемных стыков $(\mathrm{HI}, \mathrm{H2})$

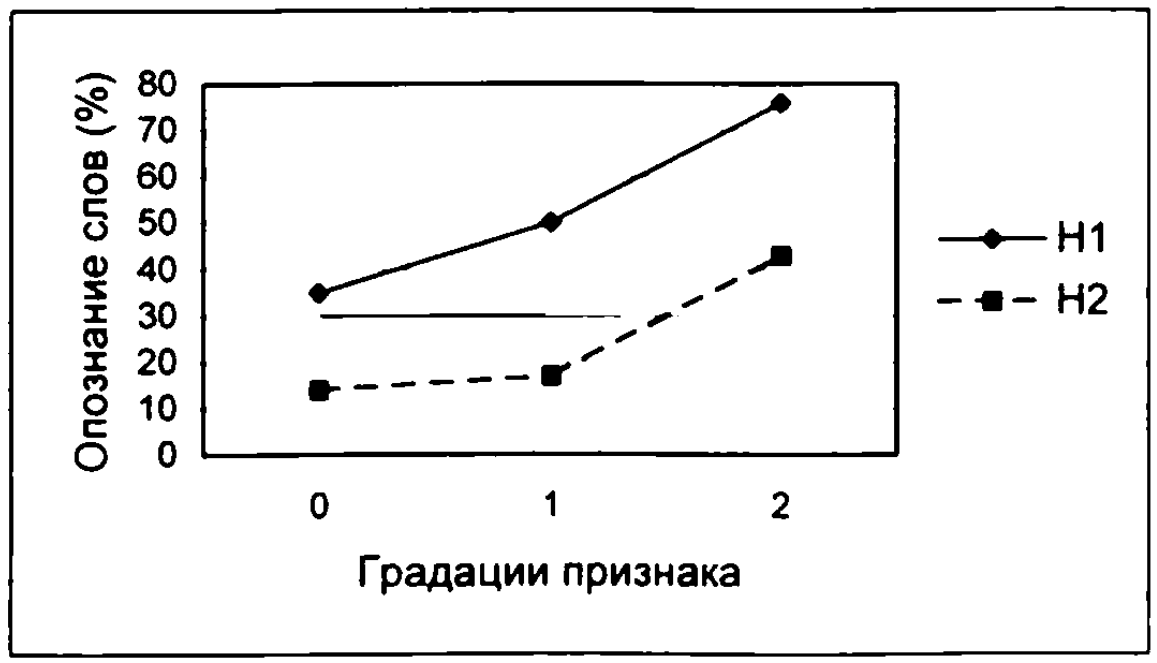


Рис. 15. Восприятие русских слов в зависимости от количества слого-морфемных стыков (P)

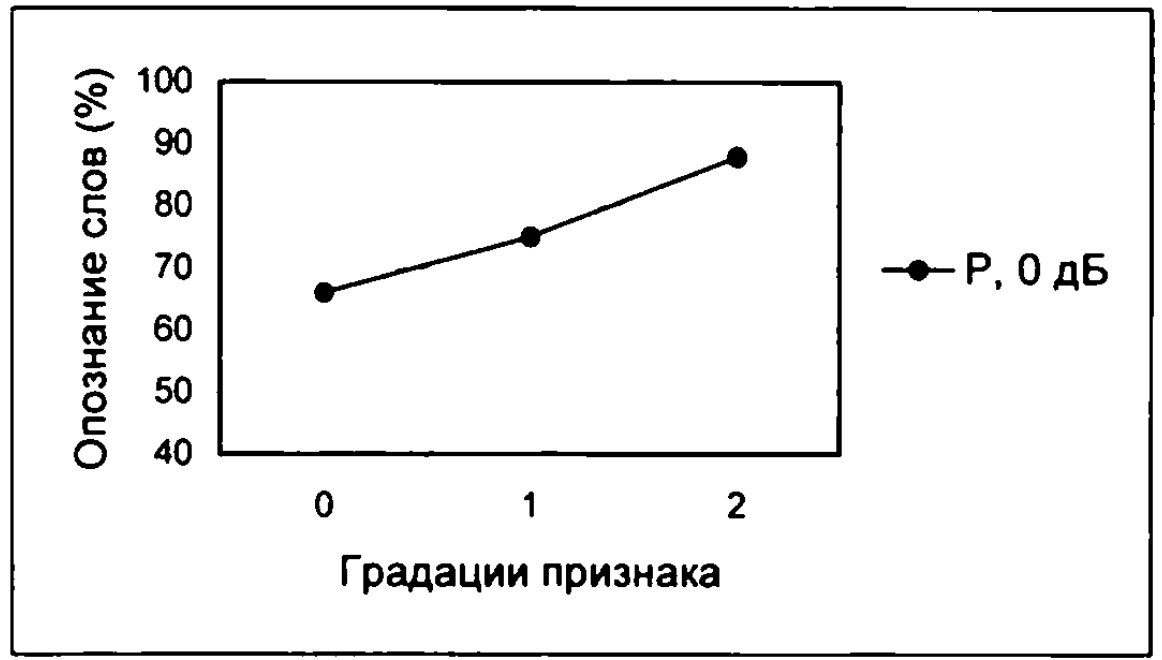

\subsection{6 Факторы фонемного уровня}

Фактор "ударная гласная фонема" относится также, как и в русском и английском языках, к ведущим лингвистическим признакам.

Из рис. 16 следует, что слова с ударением на дифтонге /aе / и на долгих напряжённых гласных воспринимается, как правило, лучше слов с краткими ненапряжёнными ударными гласными.

Рассмотрим отдельно восприятие слов с ударными долгими и краткими гласными. Слова с ударным дифтонгом /ae/ и с долгими гласными выстраиваются в следующую последовательность по нисходящему опознанию:

$$
\begin{aligned}
& \text { H1 /ae/ - /a:/ - /u:/ - /i:/ } \\
& \mathrm{H} 2 \text { /ae/ - /u:/ - /a:/ - /i:/ }
\end{aligned}
$$

В таком же порядке воспринимаются сами гласные (рис. 17) ${ }^{30}$. Очевидно, он прежде всего связан с протяжённостью гласных. В ударной позиции выстраивается следующий ряд по убывающей длительности:

$$
\text { /a:/ - /e:/ - /o:/ - /u:/ - /i:/ [Вейсалов 1980:248]. }
$$

Сопоставление ранговых последовательностей слов с краткими ненапряжёнными ударными гласными выявляет большие расхождения между режимами:

H1 $/ \mathrm{u} /-/ \mathrm{a} /-/ \mathbf{l} /$

${ }^{30}$ Правда. в режиме $\mathrm{Hl}$ опознание ударной /а:/ немного опережает дифтонг /ä. 
$\mathrm{H} 2 / \mathrm{l} /-/ \mathrm{w} / \mathrm{/a} /$.

Последующий анализ опознания самих ударных гласных подтверждает, что в режиме $\mathrm{Hl} / 1 /$ воспринимается хуже других кратких гласных, а в режиме Н2 - лучше их (рис. 17).

Рис. 16. Восприятие слов в зависимости от ударной гласной фонемы $(\mathrm{H} 1, \mathrm{H2})$

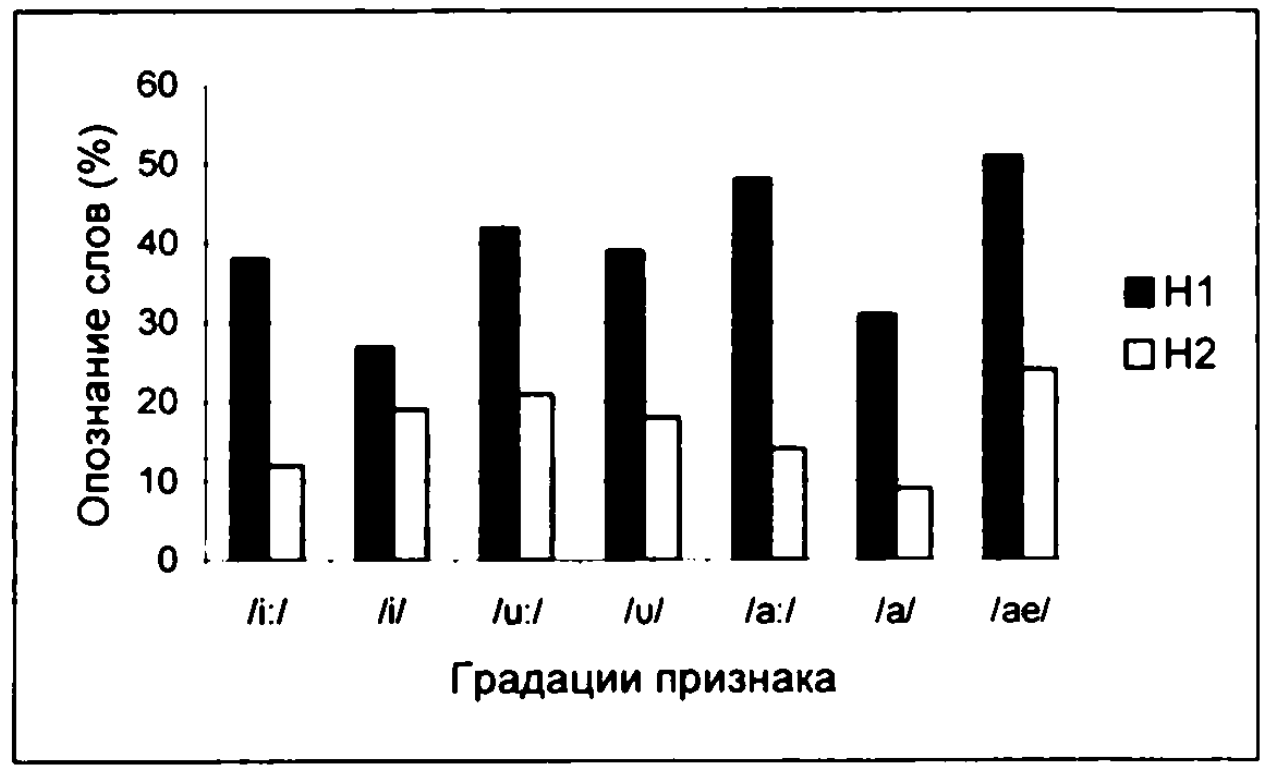

Рис. 17. Опознание ударных гласных $(H I, H 2)$

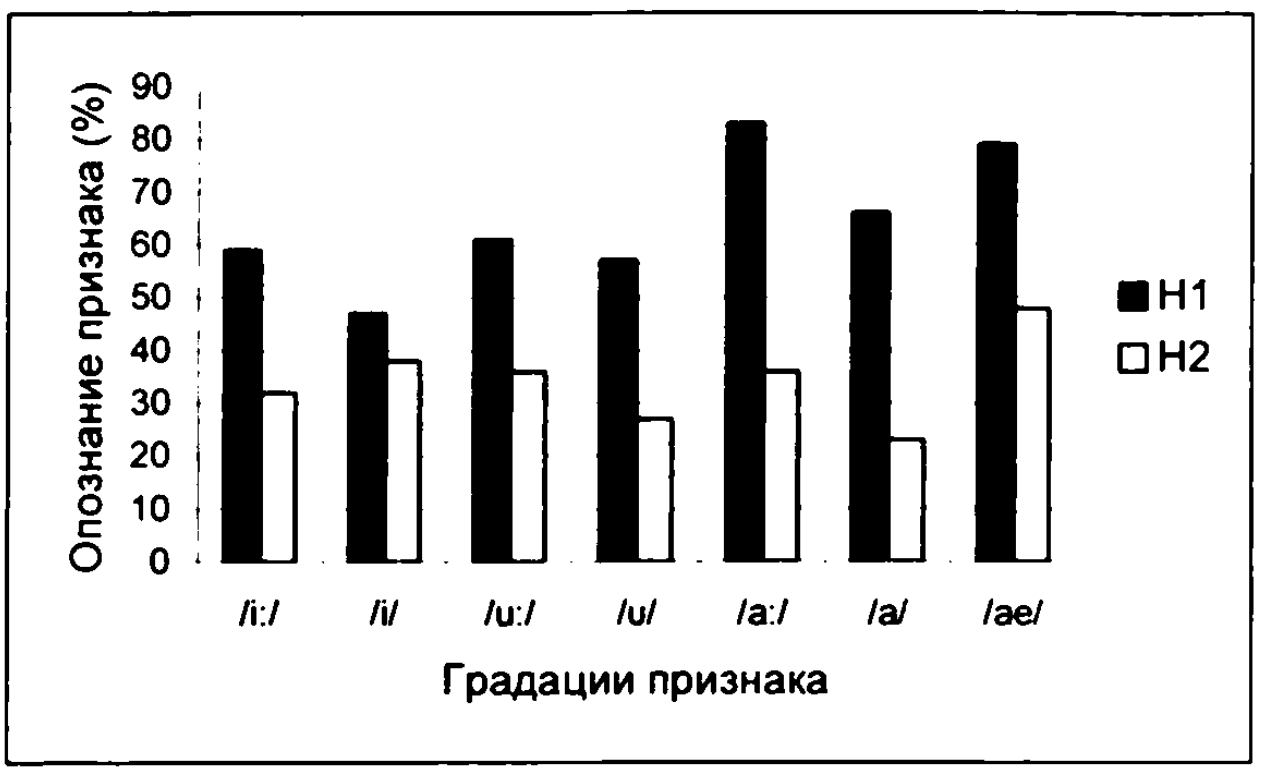

Возникает мысль о том, что поведение градаций фактора связано с различной фонетической нагрузкой долготы/краткости и напряжённости/ненапряжённости у отдельных гласных фонем (см. [Sendlmeier 1981: 
299-301]). В целях уточнения этой гипотезы определяются отношения среднего опознания кратких гласных к среднему опознанию соответствующих гласных (табл. 7).

Таб̆лица 7. Отночение среднего опознания кратких гласных к среднеку опознанию соответствующих долгих гласных

\begin{tabular}{|l|l|l|}
\hline Гласные & Режим & H2 \\
\hline /a/:/a:/ & 0,80 & 0,64 \\
\hline$/ \mathrm{u} /: \mathrm{u}: /$ & 0.93 & 0,75 \\
\hline$/ 1 /: / \mathrm{i}: /$ & 0,79 & 1,20 \\
\hline
\end{tabular}

Видно, что в наиболее тяжёлом режиме $\mathrm{H} 2$ сильнее всего дифференцируется восприятие /a:/ и /a/. Это те фонемы, которые отличаются друг от друга прежде всего длительностью [Sendlmeier 1981:303; Meinhold, Stock 1982:89]. Наименьшие расхождения наблюдаются у /i:/ и /1/, причём /s/ воспринимается лучше /i:/. Они различаются не столько количественно, сколько качественно [Sendlmeier 1981:229]. Интересно, что /u:/ и / $\mathrm{U} /$ занимают промежуточное положение. Очевидно, это связано с тем, что в этой оппозиции качественные и количественные характеристики конкурируют между собой [там же]. На основе этих данных можно предположить, что в крайне трудных условиях приёма качественная дифференциация гласных одной пары способствует их правильному восприятию, между тем как длительность используется менее успешно. В этой связи следует упомянуть результаты восприятия немецких слов русскими ии. [Акопян 1985]. Слова с ударными /i:/ и /1/ воспринимаются ими или одинаково, или в пользу краткой градации. В остальных случаях слова с долгими гласными воспринимаются лучше слов с краткими ударными. Таким образом, в восприятии иностранцев фактор ведёт себя примерно так же, как у носителей языка в более трудных условиях приёма.

В режиме $\mathrm{Hl}$ происходит некоторое выравнивание результатов восприятия. Сближается опознание кратких и долгих ударных гласных (табл. 7). Видимо, признак краткость/долгота используется более зффективно.

Изложенные выше результаты подтверждают данные В.Ф. Зендльмайера о различной функциональной нагрузке признаков в гласных фонемах немецкого языка [Sendlmeier 1981]. Они также показывают, что качественная дифференциация фонем одной пары более помехоустойчива, чем количественная. 
Рассмотрим теперь характер замен ударных гласных. Итоги этого анализа не охватывают системы немецких гласных целиком. В рис. 39а (см. п. 4.5.6) сплошной линией обозначены основные замены, т.е. те, которые происходят между представленными в исходном материале гласными. Они одинаковы в обоих режимах. Дополнительный анализ реакций в режиме $\mathrm{Hl}$ выявил достаточно регулярные замены на гласные, не включённые в число рассматриваемых градаций фактора "ударная гласная фонема". Они в рис. 39а обозначаются пунктирной линией.

Как видно, гласные заменяются и по ряду, и по подъёму. Этим немцы отличаются от носителей русского языка, которые заменяют ударные гласные в основном по ряду [Отчёт ЛЭФ 1973:78]. В заменах по горизонтали, как правило, сохраняется признак долготы/краткости.

Вертикальные субституции дают менее однозначную картину. Основные замены по подъёму направлены на фонемы того же "звукотипа", но с противоположной количественной характеристикой.

На фоне дискуссии о характере немецких дифтонгов особый интерес представлют переходы /ae/ $\leftrightarrow / \mathrm{a}$. Их можно толковать в пользу монофонемной характеристики /ае / (cp. [Наумов 1982]). Видимо, имело бы смысл проанализировать восприятие дифтонгов немецкого языка в специальном перцептивном эксперименте, чтобы уточнить их статус с точки зрения перцептивного эталона.

В русском языке описание гласных определяется прежде всего их интенсивностью и частотой. Наблюдается следующая последовательность:

$/ \mathrm{a} /-/ \mathrm{e} /-/ \mathrm{o} /-\mathrm{u} /-/ \mathrm{i} /-/ \mathrm{y} /$.

Обратимся к фактору "консонантный коэффициент". Признак относится к существенным и занимает средние ранги в обоих режимах (табл. 3). Среди фонетических факторов его опережает лишь "ударная гласная фонема".

Для первых трёх градаций признака картина такова: лучше всего воспринимаются те слова, которые представляют интервал $1 \leq \mathrm{k} \leq 2$. Уже отмечено, что усреднённый консонантный козффициент немецкого слова составляет $k \approx 1,7$ [Никонов 1966:288; ср. Esser 1960:71]. Он выше, чем в русском и английском языках. Следовательно, при восприятии действует прежде всего вероятностный механизм: слова наиболее частотной градации опознаются лучше других.

Но интересно, что для слов с консонантным коэффициентом $3 \leq \mathrm{k}$ $\leq 4$ наблюдается опять рост опознания (рис. 18). Эта градация выступает в минимальном числе слов. Они кончаются группами согласных -[st], 
$-[\mathrm{mp}],-[\mathrm{x} \ln ],-[\ln ]$, которые, возможно, играют роль "ключевых" консо нансов [Гурбанов, Зиндер 1954:560], сужая класс выбора у ии. и, следо вательно, облегчая восприятие стимулов.

Рис. 18. Зависимость восприятия немечких слов от признака "консонантный коэффициент" (HI, H2)

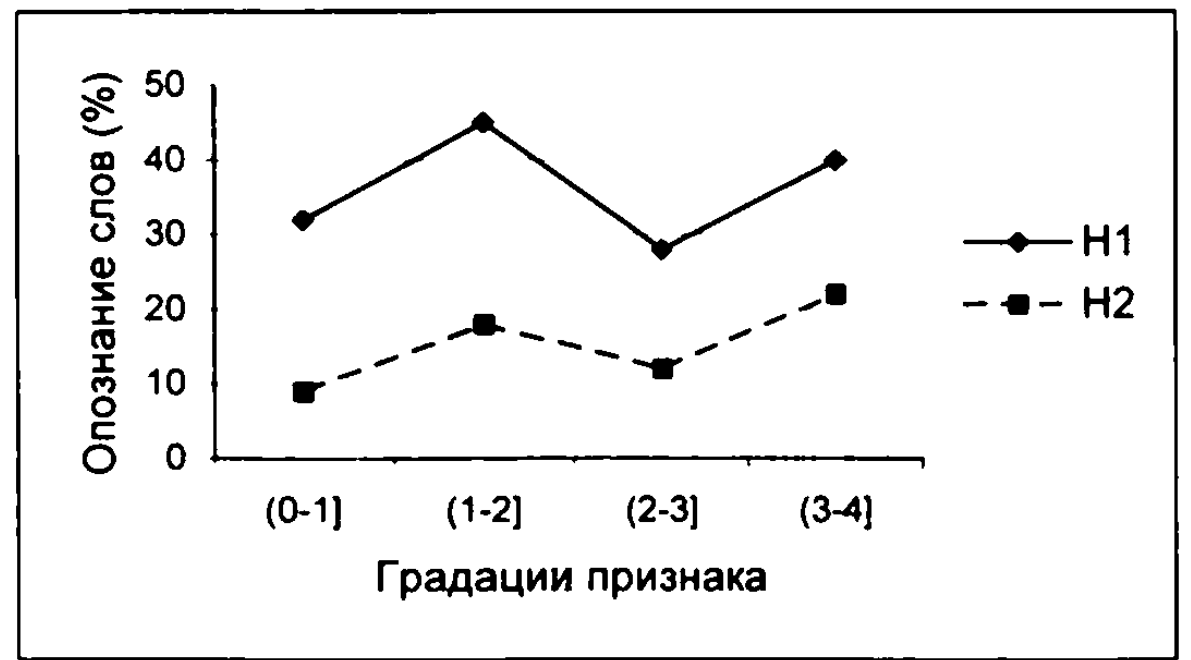

На материале русского языка обнаружена другая тенденция: чек ииже консонантный коэффициент, тем лучше слово воспринимаетс: (рис. 19). Это происходит несмотря на то, что большинство слов попада ет в интервал $1 \leq \mathrm{k} \leq 2$. Такое поведение градаций фактора можно объя снить акустически, поскольку гласные маскируются шумом меньше, чек согласные.

Рис. 19. Зависимость восприятия русских слов от признака "консонантный коэффициент" (P)

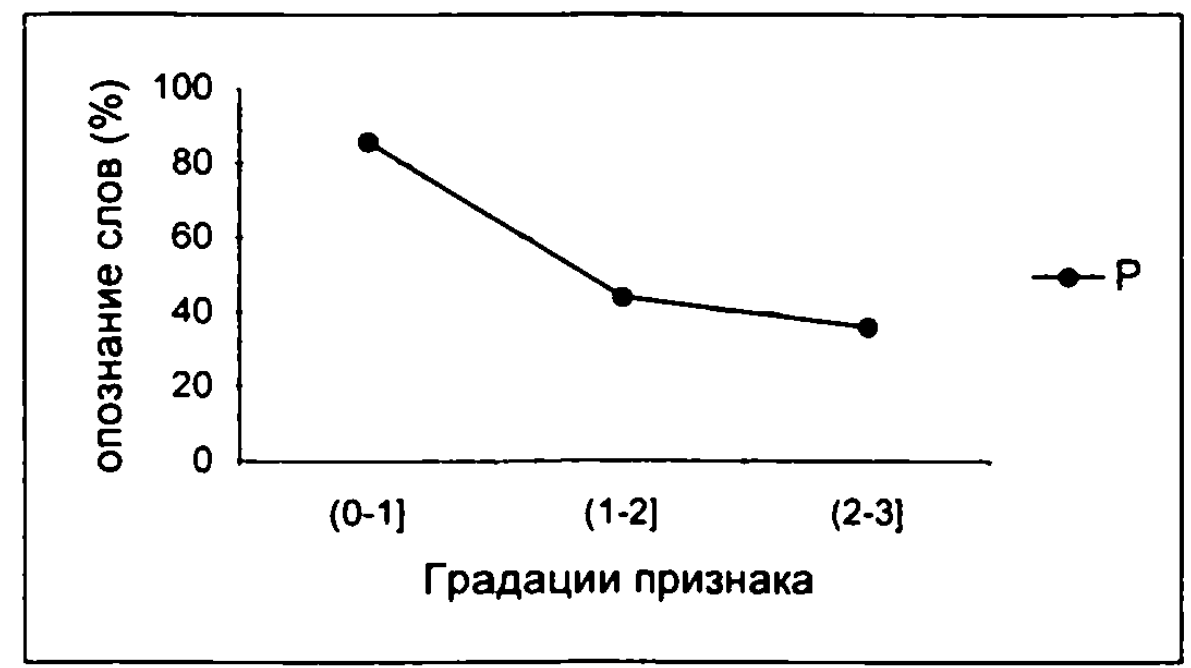


В тесной связи с предыдущим параметром состоит признак "количество консонансов". Немецкий язык богат консонантными сочетаниями [Esser 1960:72; Kim 1985:303], что следует также из довольно высокого консонантного коэффициента. В материале исследования 48 \% слов содержит один консонанс, $16 \%-2$ и более.

Признак "количество консонансов" хоть и существенен в обоих режимах, но он не относится к ведущим параметрам (табл. 2). Тем не менее результаты восприятия проявляют чёткую зависимость от фактора (рис. 20): чем больше консонансов содержит слово, тем лучше оно воспринимается.

Другой эксперимент, в котором исследовалось восприятие речи глухих нормальнослышащими аудиторами, подтверждает значимость консонантных сочетаний в восприятии [Hartmann 1965].

Рис. 20. Зависимость опознания немецких слов от количества консонансов $(\mathrm{HI}, \mathrm{H2})$

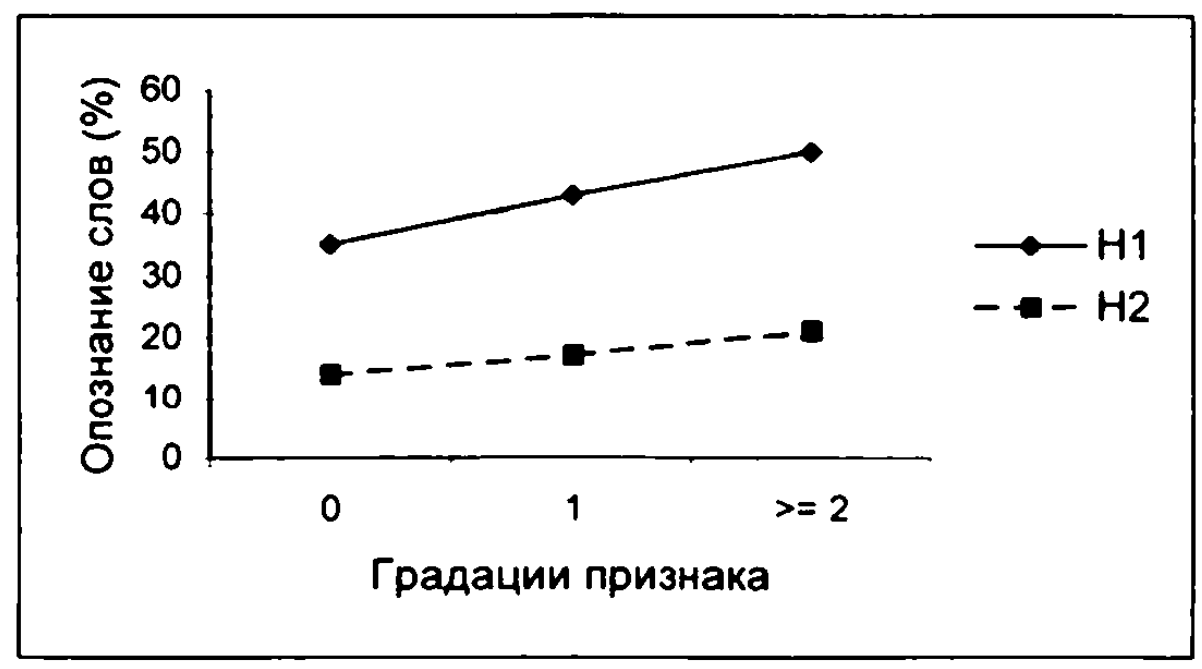

В русском языке фактор действует достаточно слабо: улучшение в опознании при -6 дБ наблюдается только для слов с двумя консонансами (рис. 21). Поэтому для русского языка делается вывод о том, что действие фактора связано с действием более сильных признаков, например, "длина в слогах" и "количество квазиомонимов".

Признак "начальный звук" несуществен в МО носителей немецкого языка (табл. 3), что повторяет данные по восприятию русских слов. Таким образом, слово воспринимается примерно одинаково независимо от того, начинается оно с гласного или согласного. 
Рис. 21. Зависимость опознания русских слов от количества консонансов (P)

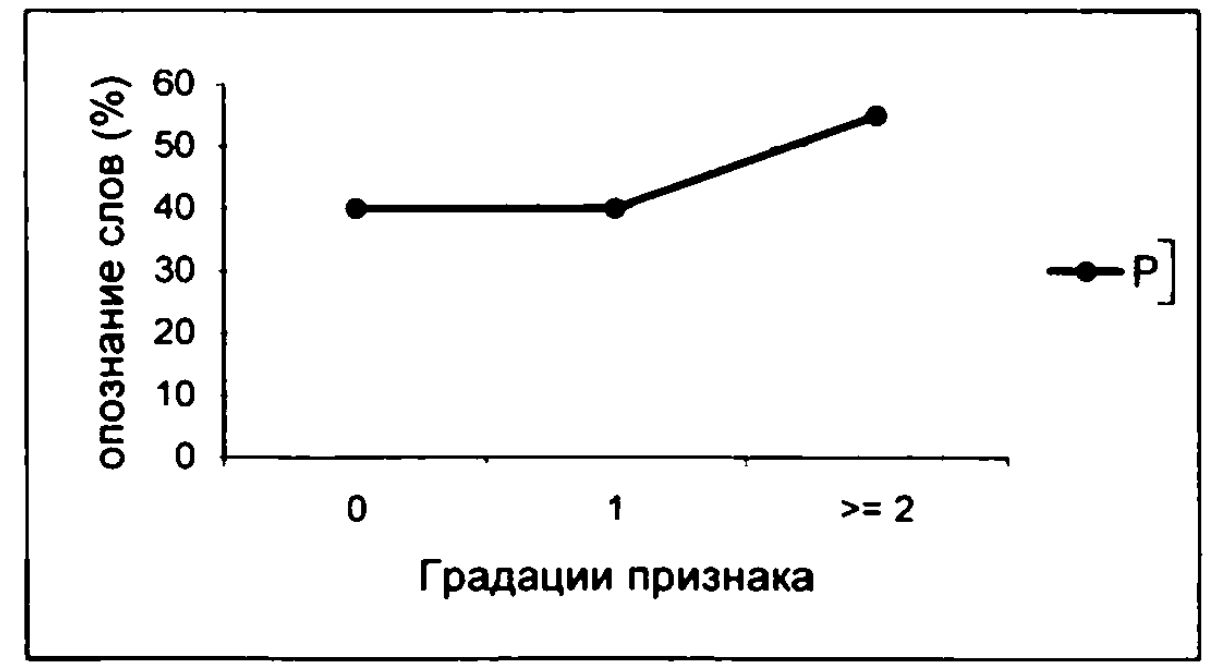

\subsection{7 Дифференциальные прнзнаки}

В режиме $\mathrm{Hl}$ факторы признакового уровня оказывают на восприяти лишь незначительное влияние (табл. 3). Средняя от рангов составляе 12,6 . Гораздо сильнее их роль в более трудном режиме Н2. Низкая сред няя от рангов $(8,7)$ является прежде всего следствием высокой значимо сти признаков "звонкость - глухость" и "фортисность - ленисность" (таб 3). Видимо, в более трудных условиях аудиторы вынуждены в больше мере вслушиваться в предъявляемый им материал; усиливается поэле ментная стратегия восприятия.

Обратимся к конкретным ДП. Признак "шумность - сонорность не имеет существенного влияния на восприятие. Это видно из рис. $2 \%$ То же самое наблюдается на материале русского языка (рис. 23).

Значение фактора "смычность - щелевость" усиливается в боле лёгких условиях приёма. Признак также существенен при восприяти русских слов русскими в аналогичном шумовом режиме. В обоих языка слова с преобладанием смычных воспринимаются лучше тех слов, котс рые состоят преимущественно из щелевых (рис. 24, 25). ПодчеркнёN что достаточно тонкий признак "смычность - щелевость" несуществен более трудном режиме $\mathrm{H} 2$. 
Рис. 22. Зависимость опознания слов от признака "цумность - сонорность" (HI, H2)

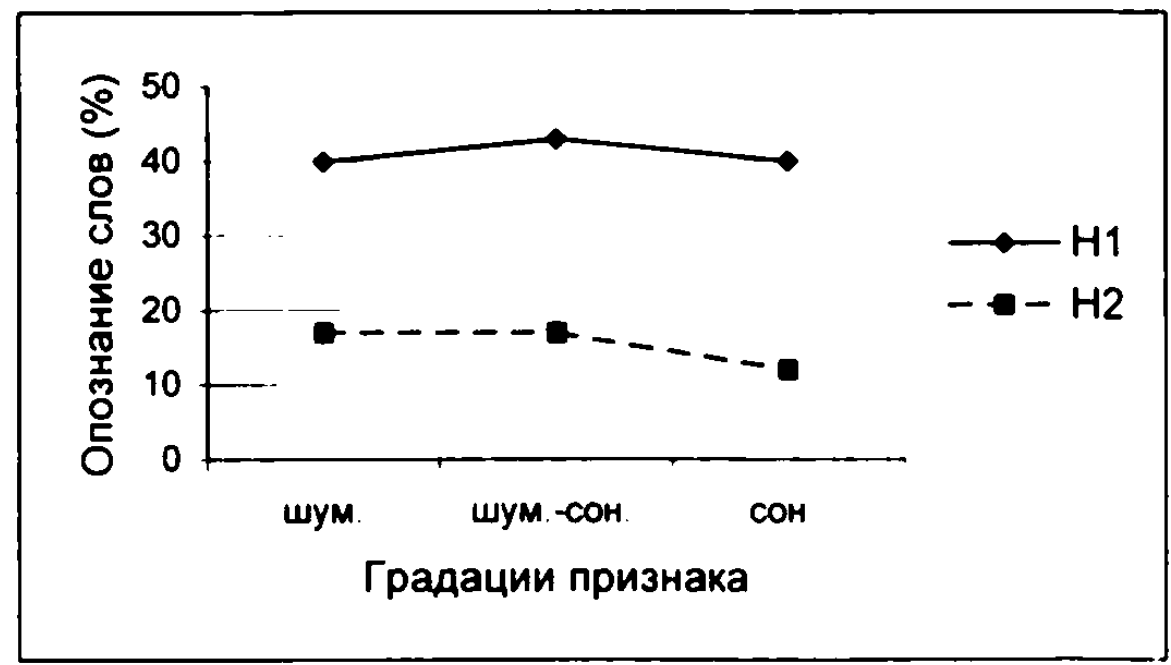

Рис. 23. Зависимость опознания слов от признака "цумность - сонорность" (P)

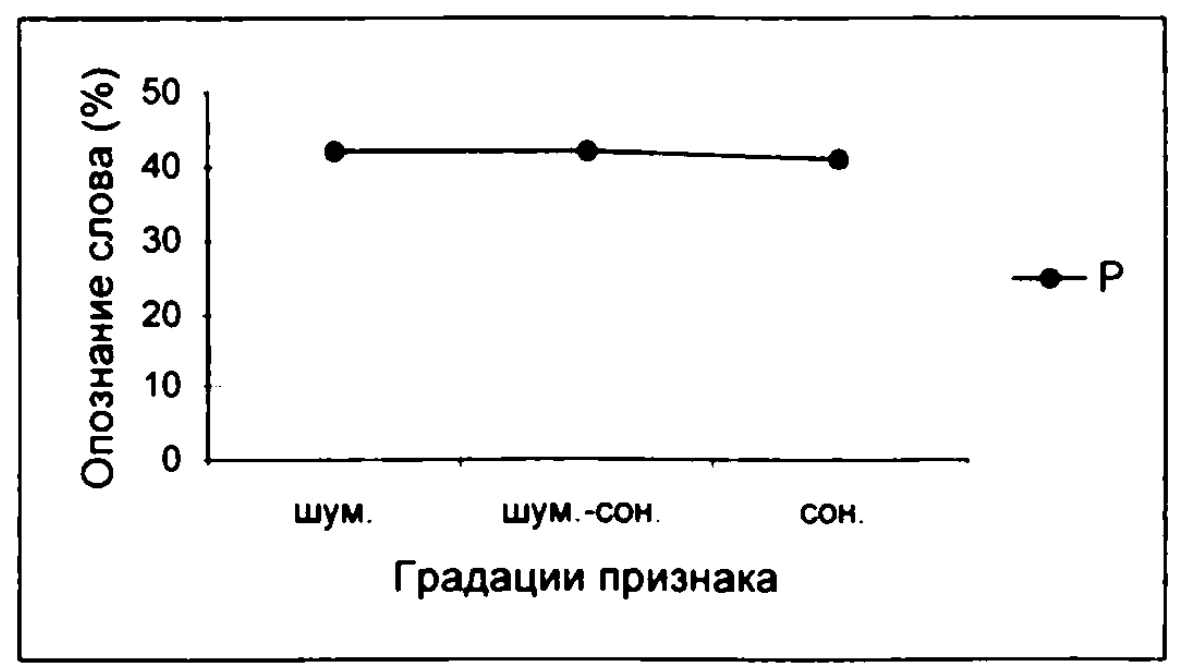

Наибольший интерес представляют факторы "звонкость - плухость" и "фортисность - ленисность". Эти признаки связаны друг с другом. Но если они в русском языке сопряжены однозначно, то в немецком языке в ряде случаев lenes оглушаются. Поэтому "фортисность - ленисность" рассматривается в немецком языке как ведущий различительный признак шумных согласных.

В крайне трудных случаях восприятия опора на эти признаки усиливается значительно. Из рис. 26 а, 6 видно, что а режиме Н2 лучше всего опознаются слова, в которых преобладают глухие, т.е. fortes. Если ведущим признаком считать "звонкость - глухость", то это нелогично, поскольку глухие согласные менее помехоустойчивы, чем звонкие [Сапож- 
ков 1963]. Очевидно, немецкие аудиторы опираются прежде всего на "фортисность - ленисность". Этот признак является существенным и в более лёгких условия $\mathrm{Hl}$, в то время как признак "звонкость - глухость" теряет свою значимость в режиме Нl. При оценке фактора "фортисность - ленисность" следует учесть, что кроме собственной напряжённости - ненапряжённости на восприятие могут влиять и другие характеристики fortes/lenes, например, длительность предшествующего гласного, характер переходов соседних гласных, длительность взрыва [Kohler 1979; Медведко, Люблинская 1987].

Рис. 24. Зависимость опознания слов от признака "смычность - щелевость" (HI, H2)

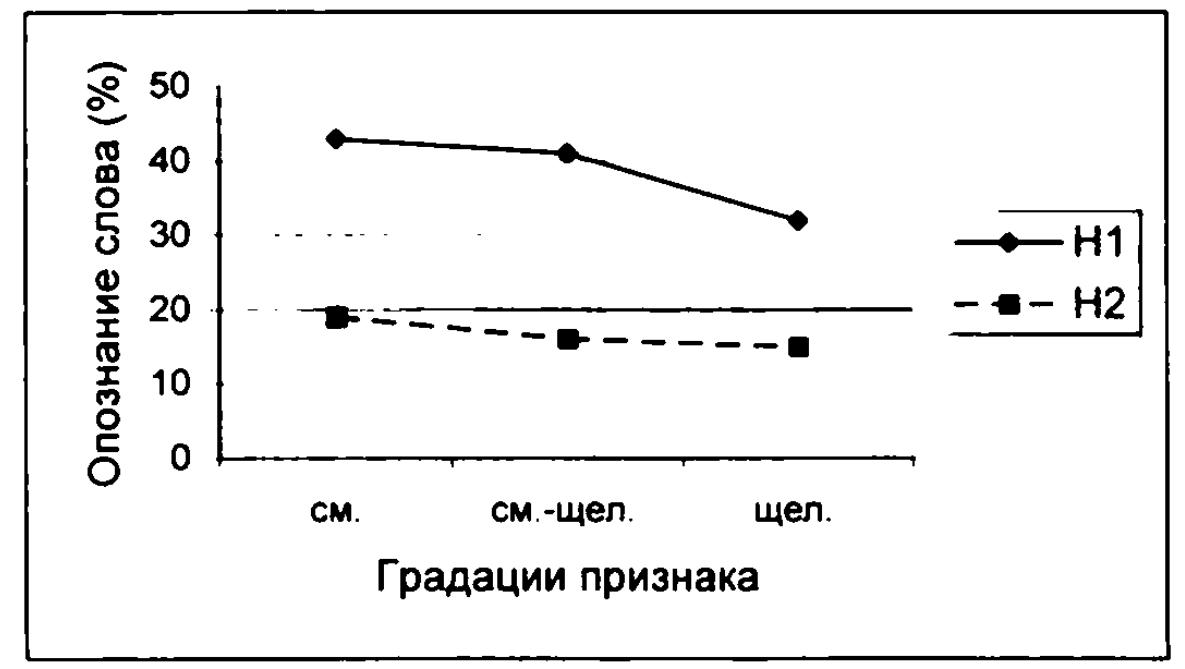

Рис. 25. Зависимость опознания слов от признака "с.мычность - щелевость" (P)

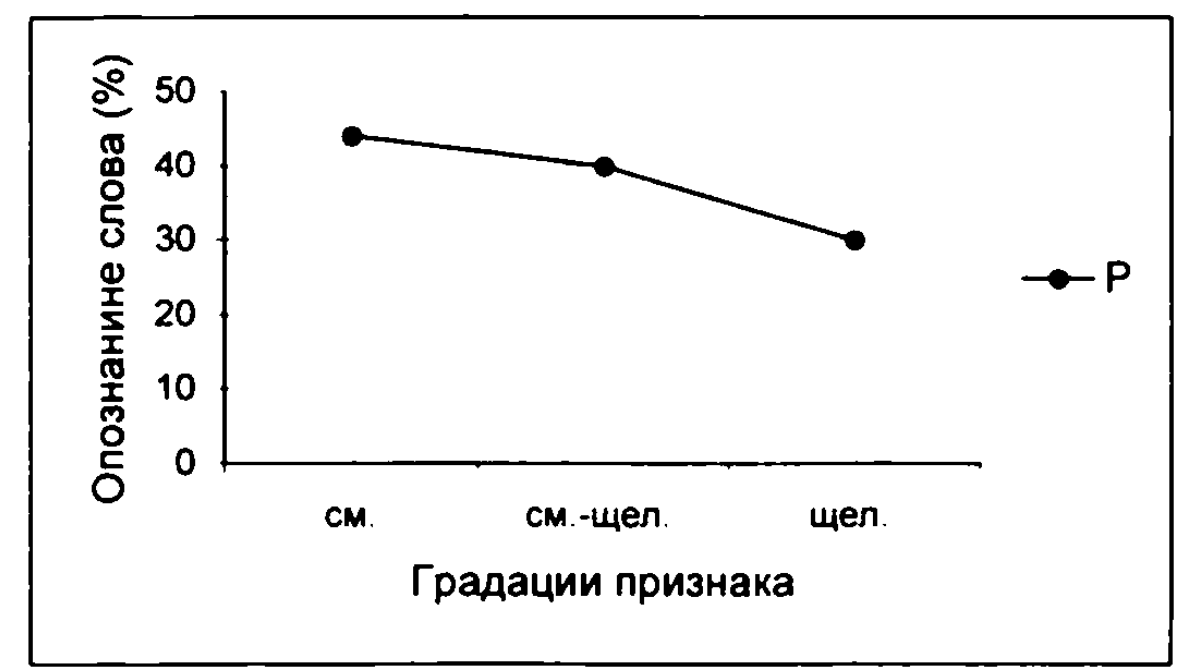


Рис. 26 а. Зависимость восприятия немечких слов от признака "звонкость - глухость" (HI, H2)

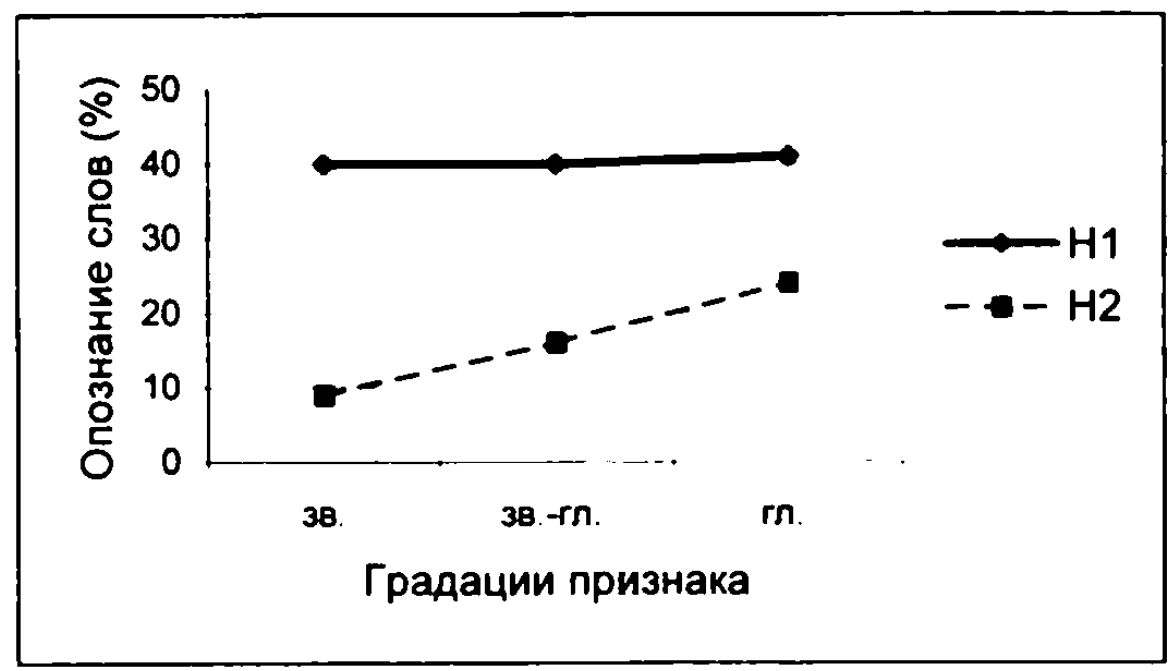

Рис. 26 6. Зависимость восприятия немечких слов от признака "фортисность - ленисность" (HI, H2)

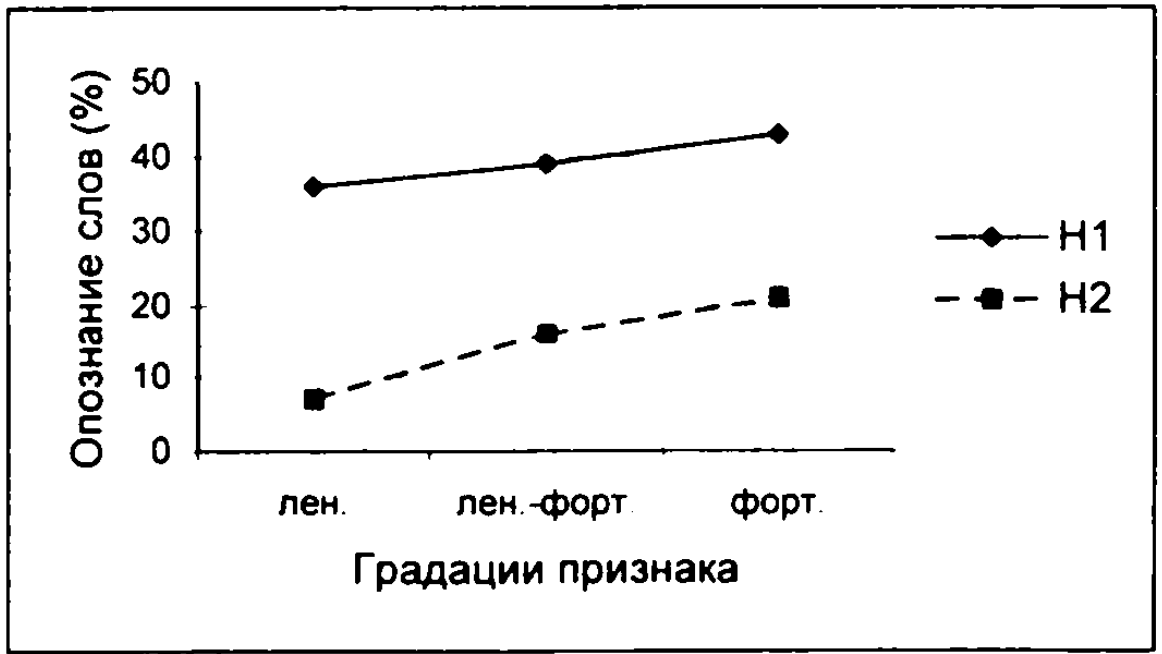

Итак, на основе данных обоих экспериментов можно предположить, что перцептивно ведущим признаком в немецком языке является "фортисность - ленисность". Русские аудиторы не опираются в аналогичных условиях на фактор "звонкость - глухость" ("фортисность - ленисность") (рис. 27). Для них перцептивно ведущим является "твёрдость мягкость". 
Pис. 27. Зависимость восприятия русских слов от признака "звонкость - глухость" (P)

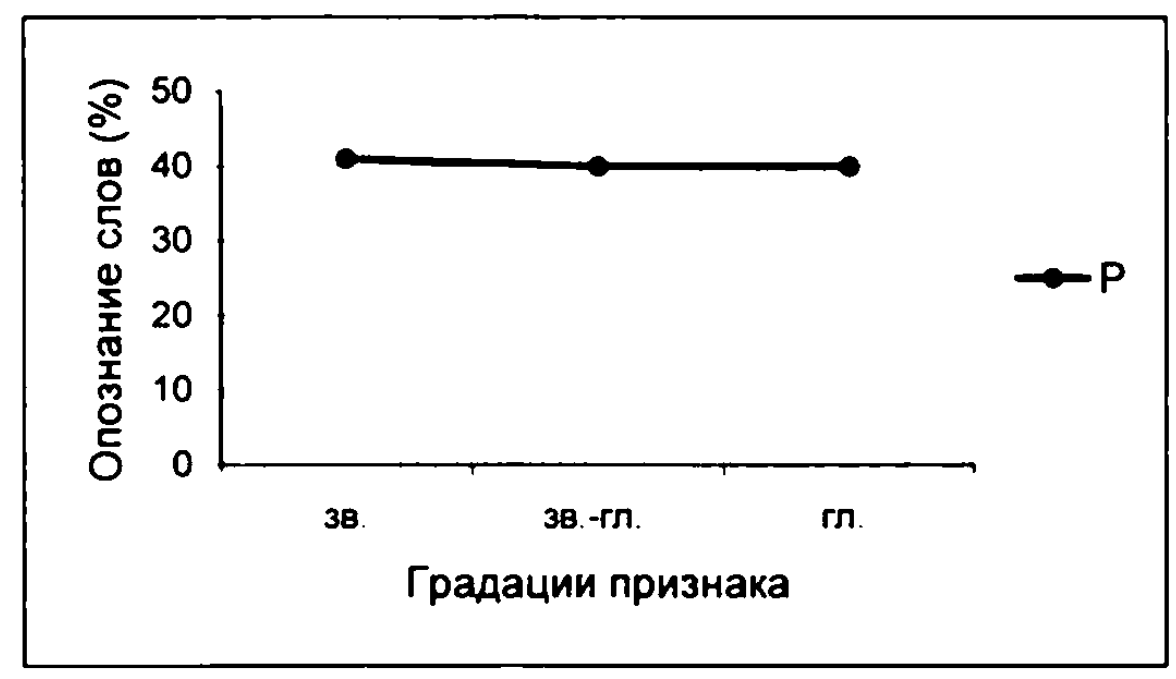

\section{5 Основные выводы}

Итак, в настоящей главе представлены результаты по восприятию немецких слов немцами в двух разных по тяжести условиях. Оказывается, что МO, определённые на разных, но типологически близких языках в примерно одинаковых условиях, ближе друг к другу, чем МO, полученные для одного и того же языка в разных условиях приёма.

На фоне данных по восприятию русских слов русскими [Штерн 1981] и английских слов американцами [Чугаева 1989] можно предположить, что структура МО в исследованных языках носит общий характер. Ведущими признаками являются, как правило, " $F_{c я 0}$ и " $F_{06}$ ", "количествC квазиомонимов", "длина в слогах", "длина в морфемах", "ударная гласная морфема". ДП согласных и фактор "начальный звук" оказывают весьма незначительное влияние на восприятие слов.

Слабая опора на признаки "длина в слогах" и "количество квазиомонимов", с одной стороны, и увеличение роли ДП и фактора "количество слого-морфемных стыков", с другой стороны, говорят о том, чтс в крайне трудных условия х приёма усиливается поэлементная стратегия восприятия. В более лёгких условиях значительно растёт опора на целостностный образ стимула (факторы "количество квазиомонимов", "длина в слогах"). Роль факторов признакового уровня уменьшается.

При анализе опознания градаций лингвистических факторов было обнаружено, что восприятие немецких слов в существенной степени определяется их морфологической структурой. Сильно выражена опора на слого-морфемные стыки. Следует также подчеркнуть, что аудиторы опираются не только на те регулярные элементы, которые бесспорно 
представляют морфемы, но и на так называемые маркеры, значение которых часто достаточно неопределённо. Подтверждается, что при восприятии любые структурные регулярности приобретают значимость. В работе было показано, что краткие ударные гласные менее помехоустойчивы, чем долгие. Подтверждаются предположения о различной перцептивной нагрузке ДП гласных в отдельных фонемах: /i:/ и /// различаются прежде всего качественно, /a:/ и /a/ - количественно (сp. [Sendlmeier 1981]). Отметим также, что среди ДП согласных в обоих экспериментальных условиях выделяется "фортисность - ленисность". 


\section{4. ВОСПРИЯТИЕ РУССКИХ СЛОВ НЕМЦАМИ (КОРПУC A)}

Известно, что иностранцы более чувствительны к внешним помехам, в частности, к белому шуму, чем носители языка. Ай.Б. Гэт и Р.В.Кейт объясняют это недостаточным лингвистическим onытом [Get, Keith 1978]. Более глубокое объяснение этого факта предлагает К. Костер [Коster 1987]: успех восприятия в затруднённых условиях связан со степенью избыточности речевой информации. Безусловно, она определяется уровнем владения языком. Как отмечают в этой связи У. Эссер и У. Хиршфильд [Esser, Hirschfeld 1984], степень избыточности информации зависит в значительной мере от доступности и прочности перцептивных "образцов" или "схем", которые сохраняются в долговременной памяти человека. Чем легче они актуализируемы, тем меньше непосредственной перцептивной информации требуется для идентификации речевых стимулов [там же : 297].

Соглашаясь с доводами процитированных авторов, мы хотим добавить, что улучшение восприятия на иностранном языке связано с приближением к механизму восприятия носителей языка. Модель механизма восприятия, по существу, включает вышеназванные факторы. Она даёт им более точное толкование, показывая, каким путём растёт способность извлекать информацию из слов изучаемого языка и применять её в ситуащии восприятия речи. Этому вопросу будут посвящены следующие главы.

Сначала анализируется восприятие людей, которые после школьного обучения русскому языку продолжали учиться в России. Это ии. корпуса A (корп. А).

\section{1 Характеристика испытуемых корпуса $A$}

В корп. А объединяются ии., проходившие включённое обучение в вузах г. Ленинграда. В 12 классе большинство из них прошло усиленное обучение русскому языку в Институте по подготовке к учёбе за рубежом в г. Халле. Поэтому уровень владения языком у этих ии. несколько выше, чем при обычном школьном обучении.

Согласно гипотезе о динамике формирования механизма восприятия, эксперименты проводились на трёх курсах включённого обучения: I к. - 12 ии., III к. -8 ии., V к. - 1 1 ии. Разница в среднем правильном опознании между курсами оказалась статистически существенной $\left(\mathrm{F}_{\text {змп }}=\right.$ 25 при $\left.\mathrm{F}_{05}=6,9\right)$. Значит, каждый корпус представляет отдельную генеральную совокупность. 
На всех курсах в эксперименте участвовали студенты гуманитарного профиля и студенты естественно-научных и технических специальностей. Bcero получено для этого корпуса ия. 4600 реакций.

\section{2 Общие результаты восприятия}

Общие результаты восприятия русских слов представлены в табл. 8. Данные показывают, что по мере овладения языком растёт количество правильно опознанных слов. В параметре "неправильные словесные реакция" проявляется яркая тенденция отождествлять стимулы со знакомыми ия. словами русского языка. Но если У. Эссер и У. Хиршфельд отмечают уменьшение словесных замен на более высоком уровне владения языком [Esser, Hirschfeld 1984:301], то у нас такая тенденция в абсолютных числах не обнаруживается. Рост "словесных реакций в целом" говорит о том, что ии. удаётся всё более успешно извлекать информацию из речевых стимулов и соотносить её с расширенным внутренним лексиконом. Об этом также свидетельствует уменьшение числа квазислов. Параллельно отмечается тенденция к снижению числа "прочих реакций" и отказов.

Таблица 8. Общие результаты восприятия слов (\%), корп. A

\begin{tabular}{|c|c|c|c|c|c|c|c|}
\hline \multirow[t]{2}{*}{ Курс } & \multicolumn{2}{|c|}{$\begin{array}{l}\text { Среднее } \\
\text { правильное } \\
\text { опозианис }\end{array}$} & \multirow{2}{*}{$\begin{array}{l}\text { Неправиль- } \\
\text { ные } \\
\text { словесивсс } \\
\text { реакции }\end{array}$} & \multirow[t]{2}{*}{$\begin{array}{l}\text { Словесные } \\
\text { реакиин в } \\
\text { целом } 31\end{array}$} & \multirow[t]{2}{*}{$\begin{array}{l}\text { Квази- } \\
\text { слова }\end{array}$} & \multirow[t]{2}{*}{$\begin{array}{l}\text { Прочие } \\
\text { реакцин }\end{array}$} & \multirow[t]{2}{*}{ Отказы } \\
\hline & $\bar{x}$ & $\sigma$ & & & & & \\
\hline I & 30 & 2,9 & 32 & 62 & 11 & 10 & 17 \\
\hline III & 32 & 2.9 & 36 & 68 & 5 & 13 & 14 \\
\hline $\mathrm{V}$ & 41 & 2.7 & 39 & 80 & 4 & 8 & 8 \\
\hline
\end{tabular}

31 Показатель "словесные реакции в целом" охватывает все русские слова, приведённые ия. в качестве ответа на стимулы. Сюда включаются и словоформы. например. пос.иотрите вместо пос.иотреть. условия вместо ус.ловие и т.п., которые рассматриваются как неправильные словесные реакиии.

32 Показатель "квазислова" включает ответы. которые представляют собой не сушествующие. но по своей фонотактической и морфонологической структуре возможные в русском языке единицы: например, трука вместо рука. пұастии вместо iпросить. че.ток вместо че.лнок.

${ }^{33}$ Иногда ии. фиксировали только отдельные звуки или звукосочетания, части слов. например. -лова (голова), воз- (возглас), -ккий (талиинский), ина (спина), асик (спросить). Эти ответы характеризуются показателем "прочие реакции". 


\section{3 Результаты дисперсионного анализа}

Как только что было показано, по мере овладения языком улучшается восприятие зашумлённых слов. Это наблюдение коррелирует с данными Ай.Б. Гэт и P.В. Кейт [Get, Keith 1978]. В дальнейшем нас будет интересовать, насколько это развитие обусловлено становлением механизма вос-приятия на иностранном языке.

Из табл. 9 видно, что число существенных для восприятия признаков стабильно: на I к. и на III к. статистически существенно 11 факторов, на V к. - 12. Но суммарное влияние факторов растёт заметно. Наибольшую весомость факторы достигают на $V$ к. $\left(\sum \mathrm{r}^{2}=0,418\right)$. Эти результаты можно рассматривать в пользу ранее высказанной гипотезы о том, что суммарный вес факторов увеличивается по мере облегчения условий приёма.

Комплекс сушественных лингвистических признаков характеризуется высокой стабильностью на всех курсах. "F суб" и "часть речи" являются определяющими факторами. С растущим уровнем владения языком к ним присоединяются факторы "количество квазиомонимов" и "ударная гласная фонема", которые отличаются нанбольшими изменениями рангов. К наиболее значимым признакам относятся также "Fo6", "консонантный коэффициент", "длина в слогах" и "длина в морфемах".

Интерес представляет взаимоотношение двух характеристик длины. На I к. факторы "длина в слогах" и "длина в морфемах" действуют примерно одинаково, хотя ии. III к. опираются несколько сильнее на морфемы, чем на слоги.

Но на V к. $\mathrm{r}^{2}$ признака "длина в слогах" превышает соответствующий показатель фактора "длина в морфемах" более чем в два раза. Аналогичное соотношение обоих прнзнаков наблюдается в $\mathrm{MO}$ на родном языке (и русском, и немецком) - ср. табл. 3, 4. Очевидно, оно характерно для высокого уровня владения языком, где слово становится нечленимым с точки зрения содержания (ср. [Сахарный 1985]) и, по-видимому, анализируется лишь по основным психологическим единицам - слогам [Леонтьев 1969:18].

На материале немецкого языка обнаружено, что существует тенденция к увеличению значимости ДП в более трудных условиях приёма. В этой связи следует указать на низкие ранги этих факторов в МО ии. корп. А, которые ещё уменьшаются: средняя от рангов ДП на I к. равна 11,75 , на III к. $-12,25$ и на V к. $-12,50$. 
Таб.лица 9. Показате.и ситы в.иияня $r^{2}$ на ранги $R$ факторов (корп. $A$ )

\begin{tabular}{|c|c|c|c|c|c|c|}
\hline \multirow[t]{3}{*}{ Daktop } & \multicolumn{6}{|c|}{ Kурс } \\
\hline & \multicolumn{2}{|c|}{1} & \multicolumn{2}{|c|}{ III } & \multicolumn{2}{|c|}{$\mathbf{V}$} \\
\hline & $\mathbf{r}^{2}$ & $\mathbf{R}$ & $r^{2}$ & $\mathbf{R}$ & $r^{2}$ & $\mathbf{R}$ \\
\hline$F_{\text {cyo }}$ & $\underline{0,139}$ & 1 & $\underline{0,124}$ & 1 & $\underline{0,139}$ & 1 \\
\hline$F_{06}$ & $\underline{0,043}$ & 3 & $\underline{0,028}$ & 5 & $\underline{0,035}$ & 5 \\
\hline Количество квазиомонимов & 0.005 & 13 & $\underline{0,033}$ & 4 & $\underline{0,044}$ & 3 \\
\hline Часть речи & $\underline{0,094}$ & 2 & $\underline{0,045}$ & 2 & $\underline{0,064}$ & 2 \\
\hline Длина в слогах & $\underline{0,013}$ & 5.5 & $\underline{0,012}$ & 7 & $\underline{0,037}$ & 4 \\
\hline Длина в морфемах & $\underline{0,013}$ & 5,5 & $\underline{0,019}$ & 6 & $\underline{0,016}$ & 7.5 \\
\hline $\begin{array}{l}\text { Колнчество слого-морфемных } \\
\text { стыков }\end{array}$ & $\underline{0,004}$ & 11 & 0,004 & 13.5 & $\underline{0,008}$ & 10 \\
\hline Ритмика $\mathrm{H}-\mathrm{C}-\mathrm{K}$ & $\underline{0,006}$ & 9 & 0.004 & 13.5 & 0,000 & 15,5 \\
\hline Консонантный козффициент & $\underline{0,021}$ & 4 & $\underline{0,035}$ & 3 & $\underline{0,033}$ & 6 \\
\hline Количество консонансов & $\underline{0,010}$ & 7 & $\underline{0,009}$ & 9 & $\underline{0,014}$ & 9 \\
\hline Ударная гласная фонема & 0,006 & 12 & 0,006 & 12 & $\underline{0,016}$ & 7.5 \\
\hline Начальный звук & 0,000 & 16 & $\underline{0.004}$ & 11 & 0,000 & 15,5 \\
\hline Шумность-сонорность & 0,002 & 14,5 & 0,002 & 15,5 & 0,002 & 13.5 \\
\hline Смычность-щелевость & 0,002 & 14,5 & 0,002 & 15,5 & 0,002 & 13,5 \\
\hline Звонкость-глухость & $\underline{0,005}$ & 10 & $\underline{0,010}$ & 8 & $\underline{0,006}$ & 11.5 \\
\hline Твёрдость-мягкость & $\underline{0,009}$ & 8 & $\underline{0,008}$ & 10 & $\underline{0,006}$ & 11.5 \\
\hline$\sum r^{2}$ & \multicolumn{2}{|l|}{0,372} & \multicolumn{2}{|l|}{0,345} & \multicolumn{2}{|l|}{0,422} \\
\hline$\sum r_{\text {cym }}^{2}$ & \multicolumn{2}{|l|}{$\underline{0.357}$} & \multicolumn{2}{|l|}{$\underline{0,327}$} & \multicolumn{2}{|l|}{$\underline{0,418}$} \\
\hline
\end{tabular}

\section{4 Результаты по ранговой корреляции}

Обратимся теперь к сравнению МО в иностранном и родном языках. Оно проводится на основе сопоставления ранговых порядков признаков. Коэффициенты корреляции представлены в табл. 10. 
Табпица 10. Козффициенты корреляции корпуса A.

\begin{tabular}{|l|c|c|c|}
\hline \multirow{2}{*}{ Коэффициент корреляция } & \multicolumn{3}{|c|}{ Курс } \\
\cline { 2 - 4 } & $\mathrm{I}$ & III & $\mathrm{V}$ \\
\hline С немецким языком & 0.29 & 0.38 & 0.64 \\
\hline С русским языком & 0.40 & 0.42 & 0.65 \\
\hline
\end{tabular}

Видно, что по мере овладения русским языком растёт корреляция с МО носителей обоих языков. Уже известно, что немцы и русские опираются на примерно одинаковый набор лингвистических признаков. Поэтому рост корреляции с обоими языками рассматривается как упорядочивание МО учащихся, который сопровождает процесс усвоения русского языка. Он отражает движение в сторону носителей языка, т.е. определённого качества владения языком. Особенно ярко это видно в признаках "количество квазиомонимов" и "длина в слогах", которые отличаются высокой значимостью в МО носителей русского и немецкого языков. Таким образом, по мере овладения языком появляется возможность всё более полного переноса МО, установленного в родном языке ии. при средней разборчивости в $41 \%$.

В то же время из табл. 10 видно, что даже у $\mathrm{V}$ к. наблюдаются значительные расхождения с MO носителей языков. Одни различия отражают специфику восприятия на неродном языке. Так, фактор "часть речи" действует в $\mathrm{MO}$ ии. корп. А значительно сильнее, чем в МО носителей русского и немецкого языков. Интересно, что и русские дети опираются на этот признак намного больше, чем взрослые носители языка [А.Зиндер, Штерн 1986]. Видимо, здесь сказывается особая установка на морфологические регулярности как части слова, которая характерна для процесса усвоения языка, становления механизма воспри

ятия. На основе наблюдений языкового развития в онтогенезе Д. Слобин сформулировал для языков флективного типа соответствующий оперативный принцип: "Обращай внимание на конец слова", по которому и действуют дети [Слобин 1984:167].

Вывод о наличии параллелей в стратегиях восприятия детей и иностранцев укрепляется ещё тем, что по мере овладения языком снижается относительный вес признака "часть речи".

Кроме того, иностранные учащиеся опираются гораздо сильнее, чем носители русского и немецкого языков, на частотные характеристики слов ("F $\mathrm{F}_{\mathrm{c} \sigma}$ ", " $\mathrm{F}_{\mathrm{0 \sigma}}$ ").

Наиболее отчётливые отклонения от $\mathrm{MO}$, определённого для носителей русского языка, обнаруживают именно эти факторы, а также признак "ударная гласная фонема". Но если для последнего фактора расстояние в рангах уменьшается у V к., то по частотным характеристикам су- 
щественные сдвиги не наблюдаются. Это обусловлено прежде всего весьма низким значением этих факторов в МО русских, которое связывается нами с особенностями в стратегии восприятия тренированных аудиторов-фонетистов (см. выше, п. 3.3.2).

Расхождения с МO русских аудиторов обнаруживается также для фактора "количество консонансов". Но поскольку действие этого фактора в большой степени детерминировано другими, более сильными факторами (в частности, "длиной в слогах" и "количеством квазиомонимов"), мы рассматриваем это различие как второстепенное.

В отличие от русских ии., немцы корп. А опираются (хотя и слабо) на фактор "звонкость - глухость", который в русском языке коррелирует с признаком "фортисность - ленисность". Возможно, здесь проявляется перенос перцептивной установки из родного языка ии. На материале немецкого языка было установлено, что опора именно на эти факторы усиливается в более трудных условиях приёма. Но тогда можно делать вывод о том, что восприятие русских слов пронсходит в субъективно достаточно сложных условиях.

Отклонения от МO, определённого на родном (немецком) языке ии., отражают изменения в сторону специфических черт МО носителей русского языка.

Существенно уменышается опора на признак "количество слогоморфемных стыков". Имеются основания полагать, что это объясняется прежде всего морфонологическими особенностями русского языка, в котором слого-морфемные стыки маркированы менее чётко, чем в немецком языке. ${ }^{34}$

Как отклонение от МО в родном языке ии. можно оценить и тот факт, что учащиеся опираются достаточно сильно на несвойственный немецкому языку признак "твёрдость - мягкость".

Итак, можно констатировать следующие тенденции: 1) По мере овладения языком происходит сближение с МО носителей русского языка. 2) Отклонение от родного языка происходит в пользу типологических особенностей изучаемого языка. Но даже на относительно высоком уровне владения языком ( $\mathrm{V}$ к. включённого обучения) $\mathrm{MO}$ изучаемого языка сформирован не полностью. При этом наиболее существенные отклонения от МO русских приходятся на признак фонетического характера, иными словами - на перцептивную базуз.

\footnotetext{
34 Уже отмечено. что по этому фактору нет данных для русских аудиторов в режиме $\mathrm{S} / \mathrm{N}=-6$ дБ.

35 Вслед за 3.Н. Джапаридзе. под пецептивной базой понимается "... единство хранящихся в памяти человска эталонов фонетических единиц и правил сравнения с ними" [Джапаридзе 1985:13]. Следует подчеркнуть. что "... восприятие того или ино-
} 
В дальнейшем будет проанализировано, насколько восприятие градаций отдельных факторов сближается с таковыми у носителей изучаемого языка. Лишь все эти данные вместе позволят сделать вывод о степени становления механизма восприятия в иностранном языке. Кроме того, они способны уточнить данные по существенности факторов.

\section{5 Анализ факторов}

\subsection{1 Объектнвная частота $\left(F_{06}\right)$, субъектнвная частота $\left(F_{\text {cy6 }}\right)$}

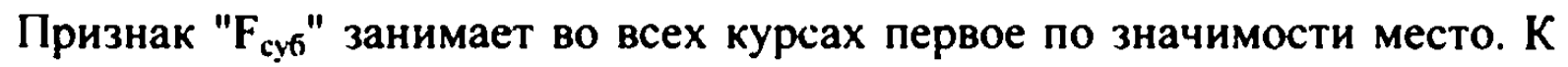
ведущим факторам относится также " $F_{о 6}$ ", хотя её влияние ниже (табл. 9).

Следует подчеркнуть, что при восприятии иноязычных слов зна-

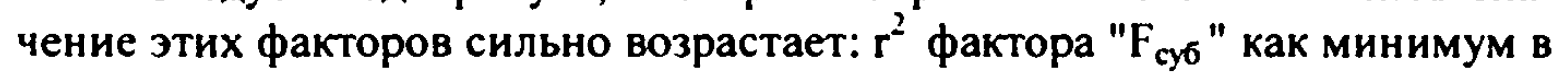
два раза сильнее, чем у носителей немецкого и русского языков. Такое же отношение проявляется при восприятии немецких слов русскими [Акопян 1985]. Относительно " $F_{06}$ " вывод подтверждается также данными по восприятию английских слов американцами и русскими [Чугаева 1989]. Следовательно, восприятие иностранцев определяется в большей степени встречаемостью слов, т.е. конкретным речевым опытом, чем это наблюдается у взрослых носителей языка. ${ }^{36}$ Усиливается опора на признак, характеризующий слово как целое.

Тот факт, что фактор " $F_{06}$ " во всех исследованных механизмах

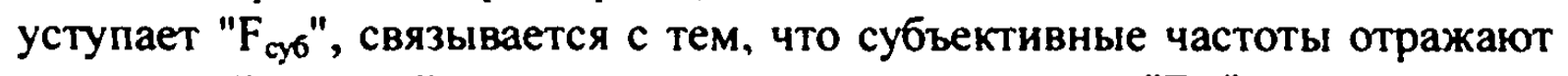
суммарный речевой опыт индивида, в то время как " $F_{06}$ ", по-видимому,

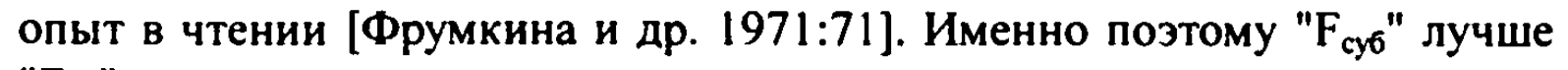
" $F_{o 6}$ " коррелирует с опознанием, что показывают и результаты настоящего исследования.

Отметим в этой связи, что вес признака "Fоб" уменьшается по мере овладения языком (см. табл. 9). Если соотносить показатели силы влияния обеих частотных характеристик слова, получается следующая картина: на I к. $\mathrm{r}^{2}\left(\mathrm{~F}_{\mathrm{of}}\right)$ составляет $31 \%$ значения $\mathrm{r}^{2}\left(\mathrm{~F}_{\mathrm{cy6}}\right)$, на III к. $22 \%$, на V к. - $25 \%$. Можно предположить, что по мере накопления живого речевого опыта уменьшается влияние " $F_{06}$ " в пользу " $F_{c y 6}$ ". Более отчётливо это прослеживается в корп. Б (см. ниже, п. 5.5.1).

го звука речи зависит не только от физических характеристик звука, но и от языковых характеристик слуха... [там же]: ср. понятие артикуляционной базы.

36 Представляется интересным сравнить. как ведут себя частотные характернстики. когда дети воспринимают слова родного языка. поскольку они также. как иностранные учащиеся, находятся в процессе усвоения языка. 


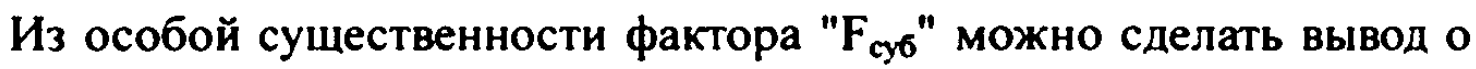
том, что в целях оптимизации преподавания языка есть необходимость в создании словаря субъективных частот большого объёма. Это было бы особенно полезно для преподавания русского языка за рубежом. Такой словарь отражал бы разносторонний речевой опыт носителей русского языка и поэтому соответствовал бы коммуникативной направленности обучения.

Рис. 28. Зависимость восприятия слов от признака " $F_{c 6}$ " (корп. A)

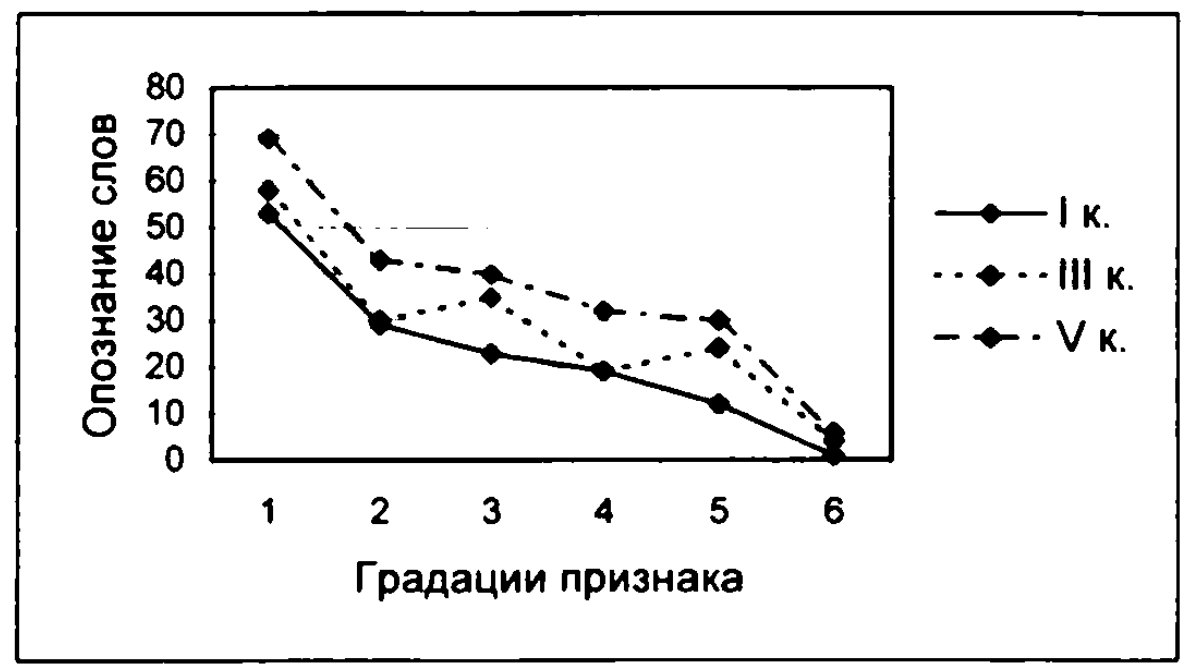

Обратимся теперь к конкретным результатам восприятия. Оба фактора обнаруживают чёткую связь между опознанием слов и частотными оценками: чем чаще слово встречается, тем лучше оно воспринимается.

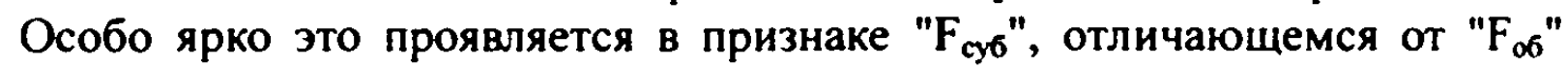
бо́льшим наклоном кривых (рис. 28, 29). Эгот факт свидетельствует о том, что немецкие учащиеся владеют "русским" речевым опытом в достаточной мере. Вместе с тем, ниже будет показано, что для данного материала частотные оценки для немецкого и русского языков довольно близки (см. ниже п. 5.5.1). ${ }^{37}$ Тем не менее немецкие учащиеся проявляют более яркую зависимость от частоты встречаемости слов, чем носители русского языка (ср. рис. 2 и 30 ).

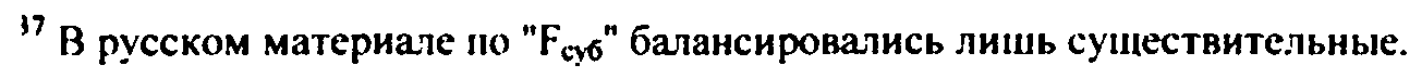


Pис. 29. Зависииость восприятия слов от признака " $F_{06}$ " (кopn. A)

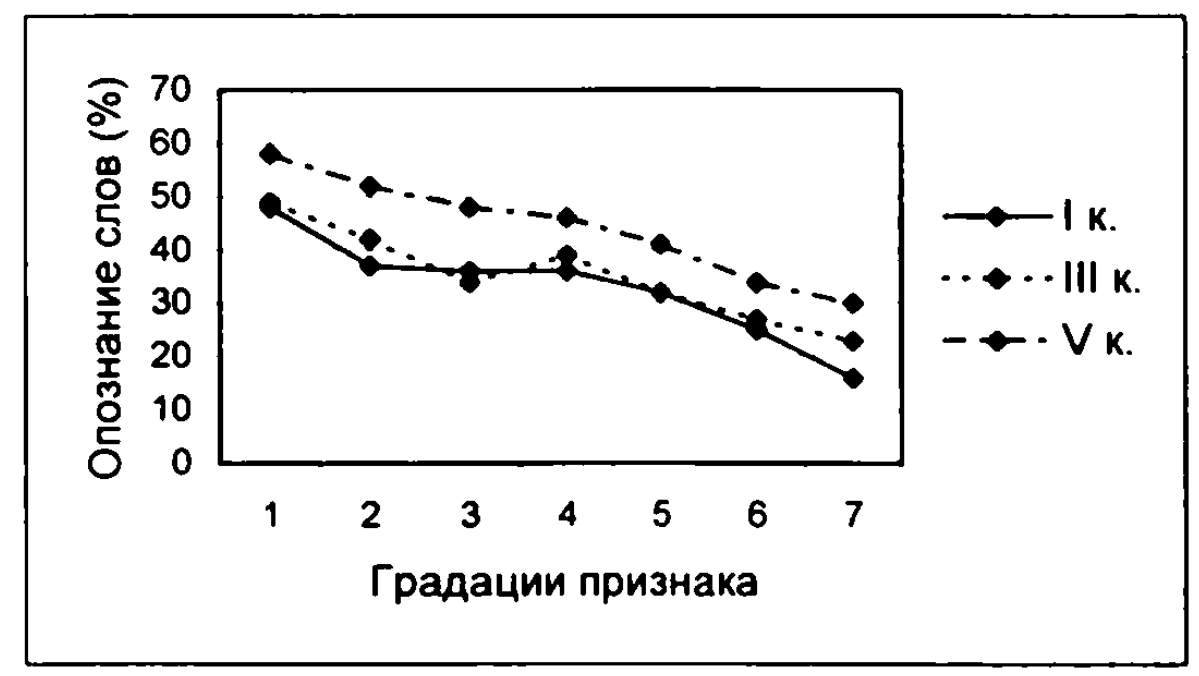

Pис. 30. Зависимость восприятия слов от признака " $F_{\text {о6" }}(P)$

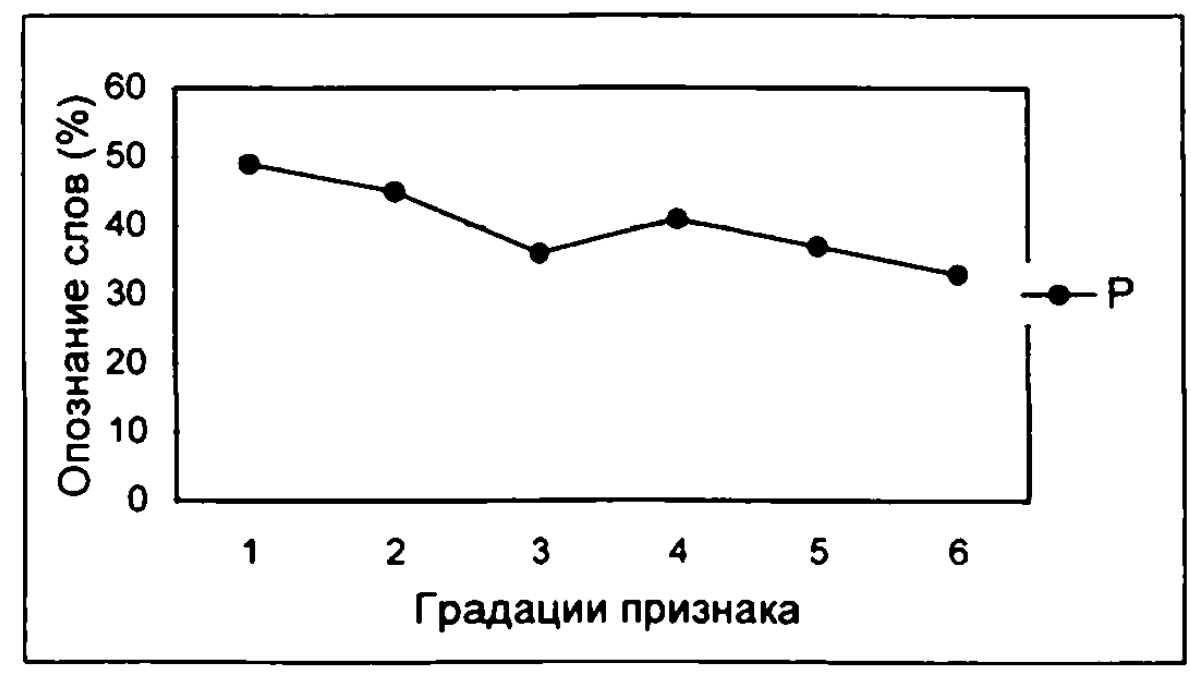

\subsection{2 Количество квазномонимов}

Ясно, что в затруднённых условиях идентификация стимула, которыг обладает множеством похожих эталонов, является психически болеє трудной процедурой, чем выбор среди небольшого количества похожия слов. Об этом говорит чёткая обратная зависимость результатов воспри. ятия от количества квазиомонимов ([Кукольщикова, Охарева, Штерғ 1979]; наст. раб. п. 3.4.2).

Можно выдвинуть гипотезу о том, что влияние фактора во многоN определяется словарным запасом ии. Поэтому следует рассмотреть этоา признак ещё с другой точки зрения: он характеризует стремление и спо. собность к семантизации нечётко услышанного стимула на основе фонетической близости. Соответственно, на высоком уровне владения вто- 
рым языком ожидается заметная дифференциация результатов восприятия.

Из рис. 31 видно, что нанболее яркая зависимость наблюдается на $\mathrm{V}$ к. Кроме того, слова с девятью и более квазиомонимами являются той градацией, в которой проявляется тенденция к ухудшению восприятия слов при переходе к более высокому уровню владения языком. Это можно трактовать в пользу нашей гипотезы. Но возможно, что опознание градаций также связано с разными стратегиями восприятия - скорее поэлементно на I к. и скорее целостно на V к. Это предположение подкрепляется ролью фактора в МO: если на I к. влияние фактора очень низко и, вдобавок, статистически несущественно, то на III к. и V к. признак относится к определяющим факторам МO (табл. 9).

\section{Рис. 31. Зависимость опознания слов от количества квазиомонимов (корп. A)}

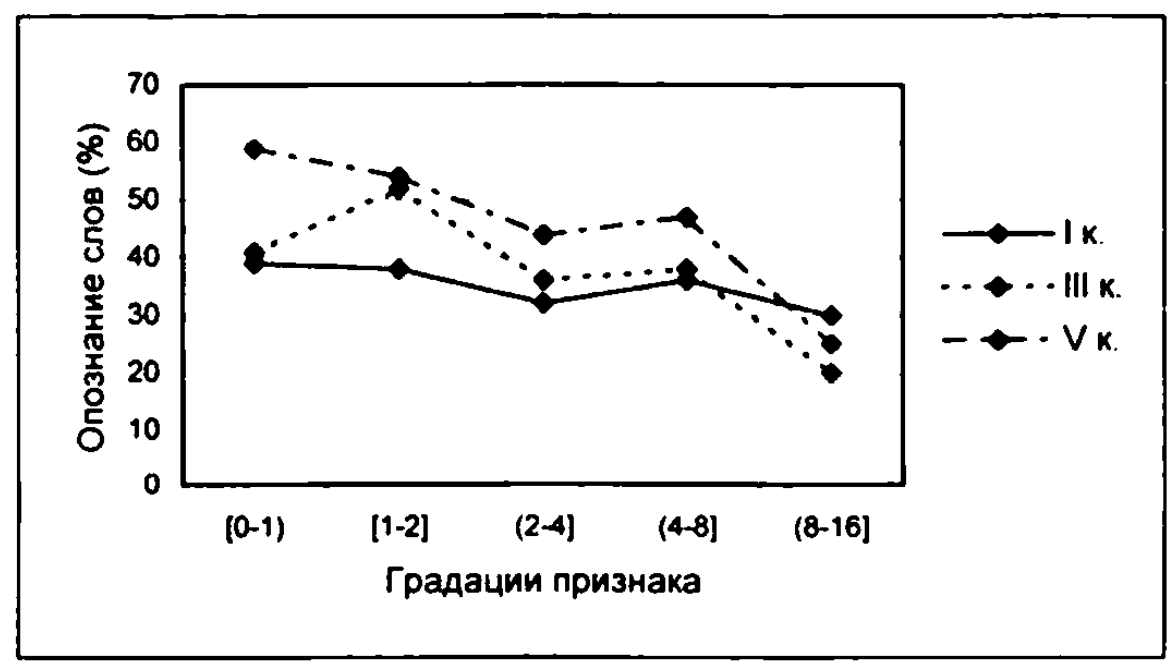

Известно, что признак "количество квазиомонимов" в определённой степени коррелирует с длиной слова: чем короче слово, тем выше вероятность того, что оно обладает большим количеством квазиомонимов [Savin 1963; Венцов и др. 1985]. Поэтому следует особо указать на то, что оба фактора действуют достаточно автономно: в механизме опоры на I к. признак "количество квазиомонимов" значительно уступает фактору "длина в слогах", между тем как он в старших группах ии. несколько превосходит значимость "длины в слогах" (табл. 9). Это можно оценить как аргумент в пользу того, что на младших курсах "длина в слогах" отражает опору на элементы (слоги). На старших курсах признак функционирует, видимо, скорее как целостный. В механизмах носителей русското и немецкого языков целостный и "семантизирую- 
щий" фактор "количество квазиомонимов" как бы подчиняется "длине в слогах" (см. табл. 3, 4).

Итак, признак действительно может послужить индикатором владения лексикой изучаемого языка. В особой степени это относится к словам с большим (девять и больше) количеством квазиомонимов. Но соответствующий тестовый материал должен быть сбалансирован по частоте словоупотребления и ожидаемости реакций - cp. также [Отчёт ЛЭФ 1988].

\subsection{3 Длина в слогах}

На материале разных языков установлено, что слово воспринимается тем лучше, чем оно длиннее [Savin 1963; Лущихина 1965; Федина, Рудая 1974; Штерн 1981; Esser, Hirschfeld 1984]. Но в эксперименте по зрительному восприятию слов и псевдослов Э. Сэмюэль, Дж. фан Сантен и Дж. Джонстон нашли, что этот факт проявляется только в восприятии слов [Samuel, van Santen, Johnston 1982]. Псевдослова анализируются прежде всего поэлементно [Данилов 1985:8; Галунов, Королёва, Шургая 1986:133]. Но то, что для носителя языка является псевдословом, для иностранца - незнакомое ему слово изучаемого языка. Следовательно, можно предположить, что влияние фактора "длина в слогах" определяется уровнем владения языком, в частности, лексикой.

В MO носителей и русского, и немецкого языков признак относится к наиболее сильным. Влияние фактора в МО ии. корп. А обнаруживает известную динамику: на V к. оно сильнее, чем на I к. и III к. (табл. 9).

С первого курса наблюдается связь между длиной слов и их опознанием (рис. 32). Но трёхсложные и четырёхсложные слова воспринимаются студентами I к. и III к. почти одинаково. Лишь на V к. восприятие слов из четырёх и более слогов значительно улучшается. Значит, с растущим владением русским языком вырабатывается механизм восприятия по длине, свойственный носителям языка. 
Рис. 32. Зависимость опознания слов от признака "длина в слогах" (корп. A)

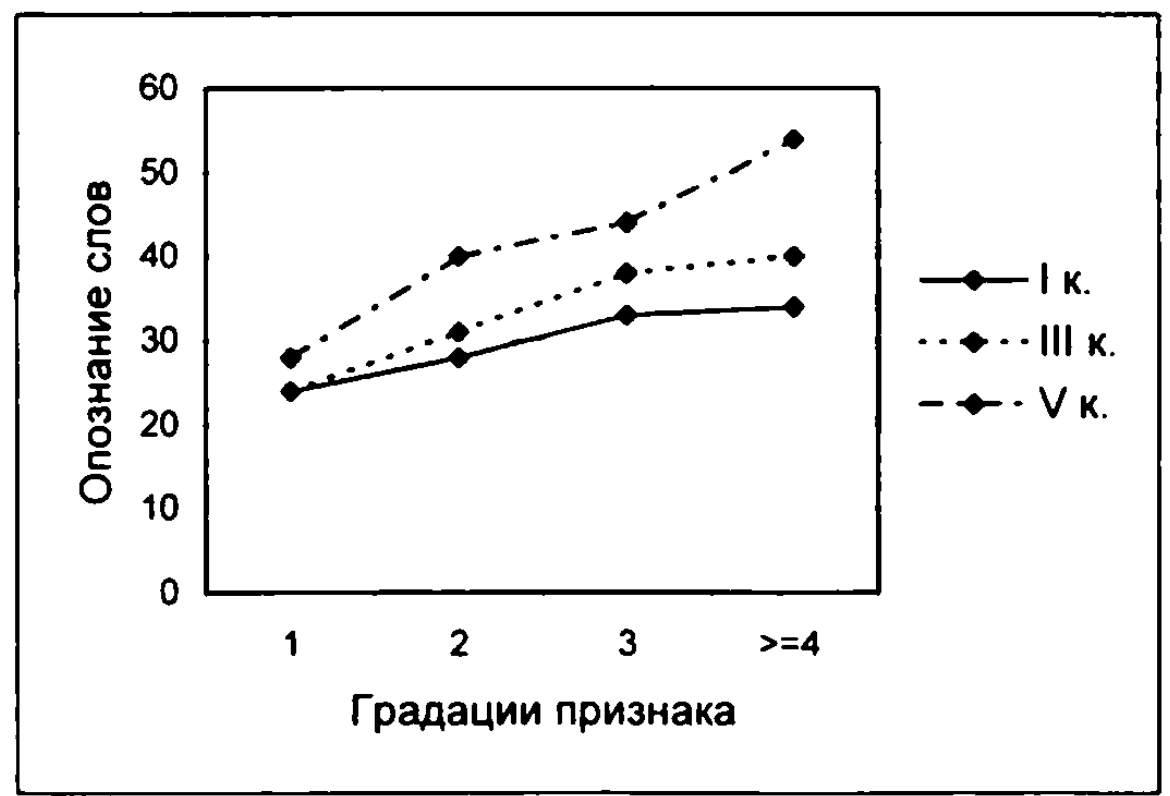

\subsection{4 Ритмическая структура}

Различия в характере словесного ударения в немецком и русском языках определяют интерес к данному признаку. Рассмотрим сначала опознание градаций фактора "ритмическая структура (а)", т.е. "в линеечку"38.

Ии. корп. А воспринимают хореические структуры лучше, чем ямбические (рис 33 а). Таким образом, помехоустойчивость первичных в онтогенезе элементов переносится на восприятие в иностранном языке.

Результаты восприятия трёхсложных слов существенно отличаются от данных, полученных для носителей немецкого и русского языков. Наиболее неблагоприятная для восприятия немцами ритмическая структура представлена словами с начальным ударением: два заударных редуцированных слога произносятся вдобавок с падающей интенсивностью. Но восприятие слов этой градации отличается наибольшим прогрессом - от $19 \%$ среднего опознания на I к. до $47 \%$ на V к. (рис. 33 б). Значит, учащиеся всё более успешно справляются с этой перцептивно сложной структурой. Наименыший рост в опознании наблюдается у слов с ударением в середине. Слова с ударением на третьем слоге характеризуются достаточно равномерным распределением интенсивности: конечноударность уменьшает спад линии интенсивности к концу слова. Если учесть, что в силу высокой энтропии внимание аудиторов направлено прежде всего на начало слова, то в целом слова с ударением на

38 Ұга разновидность описания ритмической структуры не учитывается в иерархии факторов (см. п. 3.3.1). 
третьем слоге обладают оптимальным распределением информации. Видимо, в силу этих причин они воспринимаются немцами лучше других трёхсложных слов.

Pис. 33 а. 6, в. Восприятие слов в зависимости от ритиической структуры (корп. A)

Рис. 33 а. Односложные и двухсложные слова

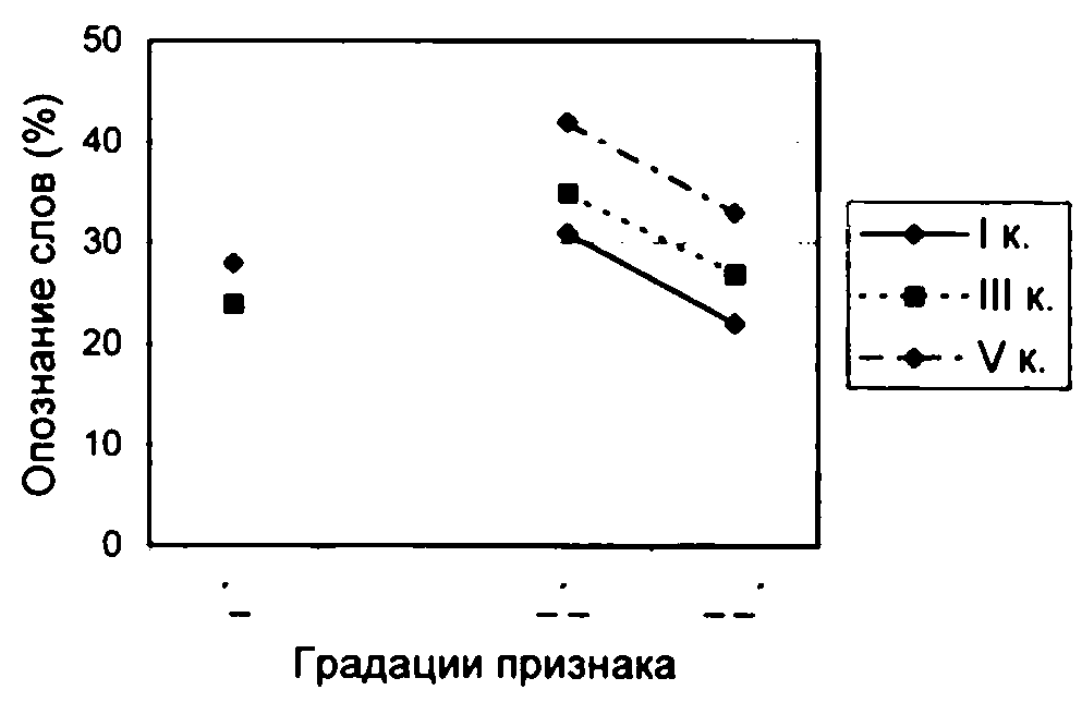

Рис. 33 6. Трехсложсные слова

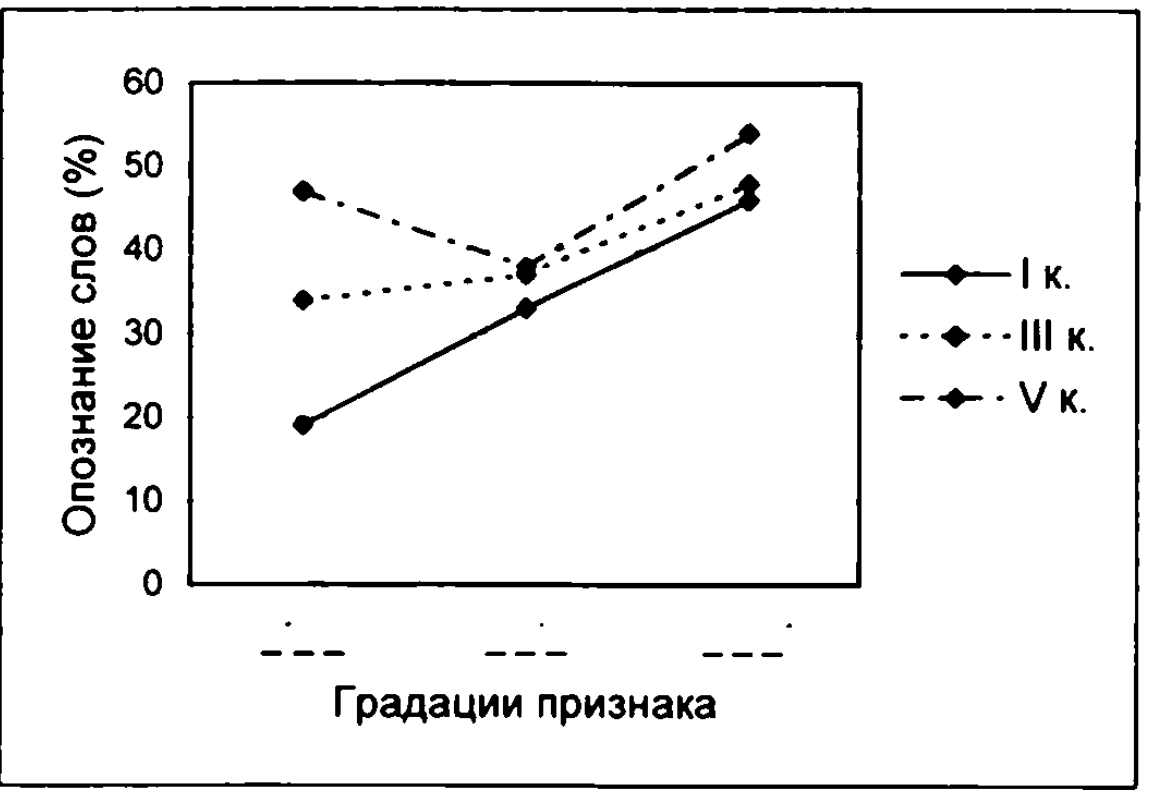


Рис. 33 в. Четырехсложные (и более) слова

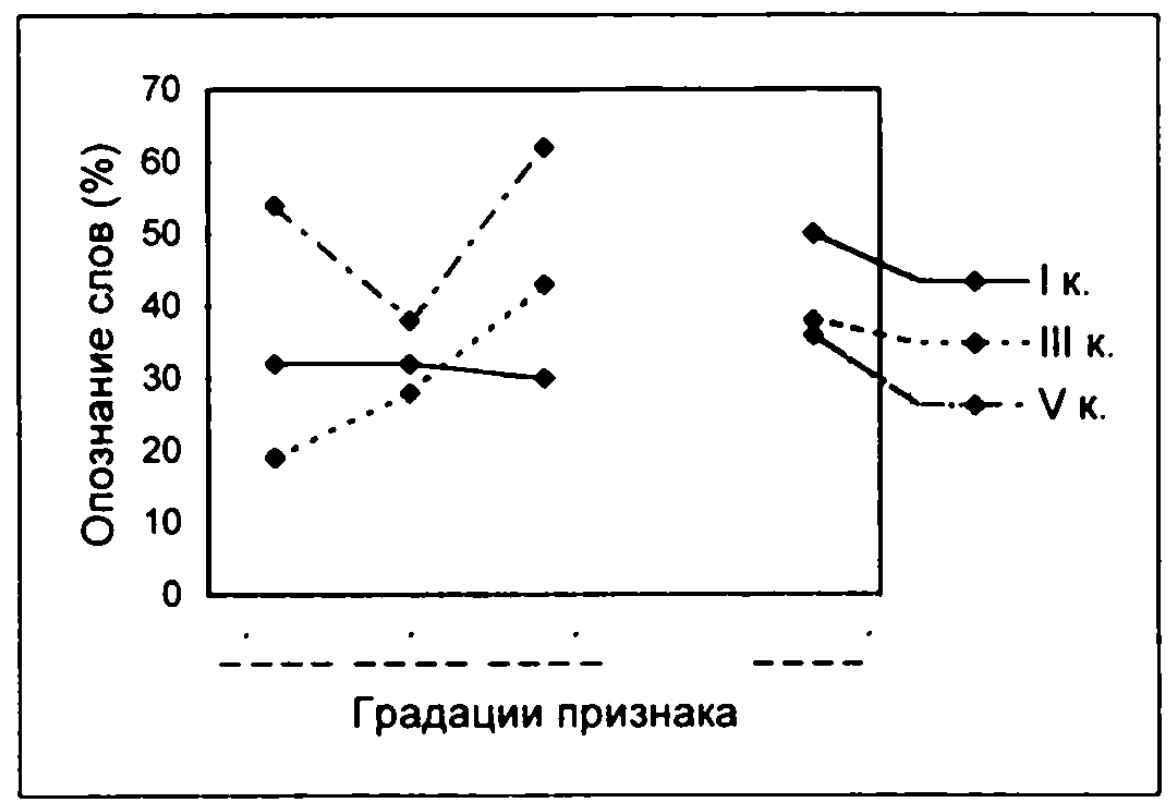

На I к. корп. А отсутствует зависимость результатов восприятия четырёхсложных слов от их ритмической структуры. Это говорит о том, что данные слова воспринимаются поэлементно (послогово). III к. и V к. обнаруживают ту же тенденцию, что и при восприятии трёхсложных слов: лучше всего воспринимаются слова с ударением на третьем слоге. Фонетически не объясним тот факт, что четырёхсложные слова с ударением на втором слоге опознаются студентами $V$ к. хуже слов с тремя заударными слогами.

Таким образом, в поведении этого фактора наблюдается перенос из родного языка ии. в том смысле, что рано усвоенные ритмические структуры высоко устойчивы к помехам и в иностранном языке. Предполагается, что здесь проявляется некая универсалия человеческого восприятия. Опознание же других градаций подчиняется особенностям изучаемого языка, в котором словесное ударение в силу своего свободного и подвижного характера менее грамматикализовано, чем в родном языке ии. Соответственно, восприятие определяется в основном фонетическим обликом слов, в частности, распределением безударных слогов.

Влияние обобщённото признака "ритмика $\mathrm{H}-\mathrm{C}-\mathrm{K}$ " незначительно во всех исследованных МО. Как видно из рис. 34 , на I и III к. слова с начальным ударением воспринимаются хуже других слов. В восприятии русских обнаружена другая тенденция: опознание слов ухудшается с передвижением ударения к концу. Значит, наличие заударных слогов не затрудняет восприятие русских настолько, как это наблюдается у немцев. Выравнивание результатов восприятия на $\mathrm{V}$ к. оценивается поэтому как движение в сторону носителей русского языка. 
Pис. 34. Восприятие слов в зависимости от места ударения H-C $-K$ (кopn. A)

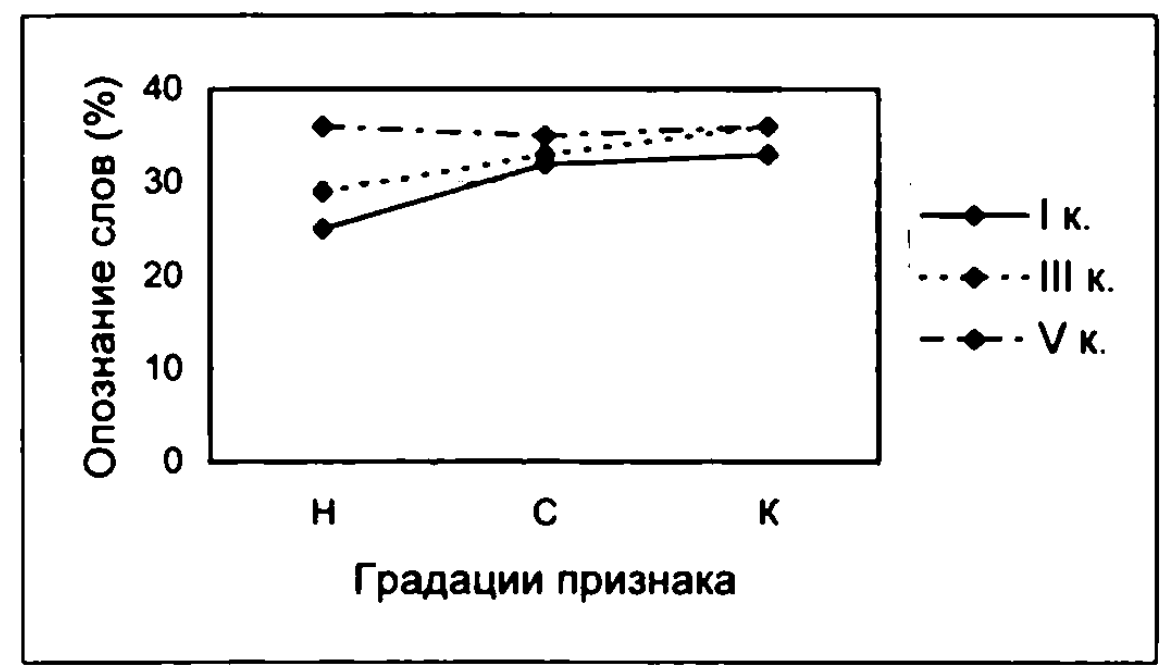

\subsection{5 Прнзнаки морфемного уровня}

При помощи фактора "часть речи" исследуется в первую очередь роль морфологических примет (маркеров) в процессе восприятия. Как уже отмечалось, немецкие учащиеся опираются на этот признак больше, чем носители русского языка. ${ }^{39}$ Это подтверждается анализом восприятия градаций (рис. $35 \mathrm{a}, 6)$. По среднему правильному опознанию слов части речи выстраиваются в следующей последовательности:

$$
\begin{aligned}
& \text { I к.: } ч-\Pi-\Gamma-C-M ; \\
& \text { III к.: Ч }-\Pi-\Gamma / C-M ; \\
& \text { V к.: Ч }-\Pi-\Gamma-C-M ; \\
& \text { Р : Ч }-\Pi / C-\Gamma-M .
\end{aligned}
$$

Лучше всего воспринимаются слова тех частей речи, которые морфологически маркированы наиболее однозначно. Это числительные и прилагательные. Наличие морфологического маркера создаёт некоторую избыточность информации. Особо ярко это проявляется у числительных, которые образуют замкнутый круг морфемных комбинаций. К примеру, чётко услышанное -надцать ограничивает возможные сочетания на небольшое число элементов. Поэтому вероятность правильного опознания числительных выше, чем прилагательных и тем более существительных. При этом следует отметить, что, начиная с I к., числительные воспринимаются немцами лучше, чем русскими. Думается, что это ещё связано

39 Сравнение с МO немцев в родном языке не позволяет делать однозначных выводов. так как в немецком материале учитываются только три градация данного фактора. 
При этом следует отметить, что, начиная с I к., числительные воспринимаются немцами лучше, чем русскими. Думается, что это ещё связано с тем, что в силу их коммуникативной значимости числительным уделяется много внимания на занятиях по русскому языку. Возможно, сказывается также опора на вероятностный механизм, так как числительные относятся к высокочастотной лексике.

Pис. 35 а. Восприятие слов в зависимости от признака "часть речи" (корп. A)

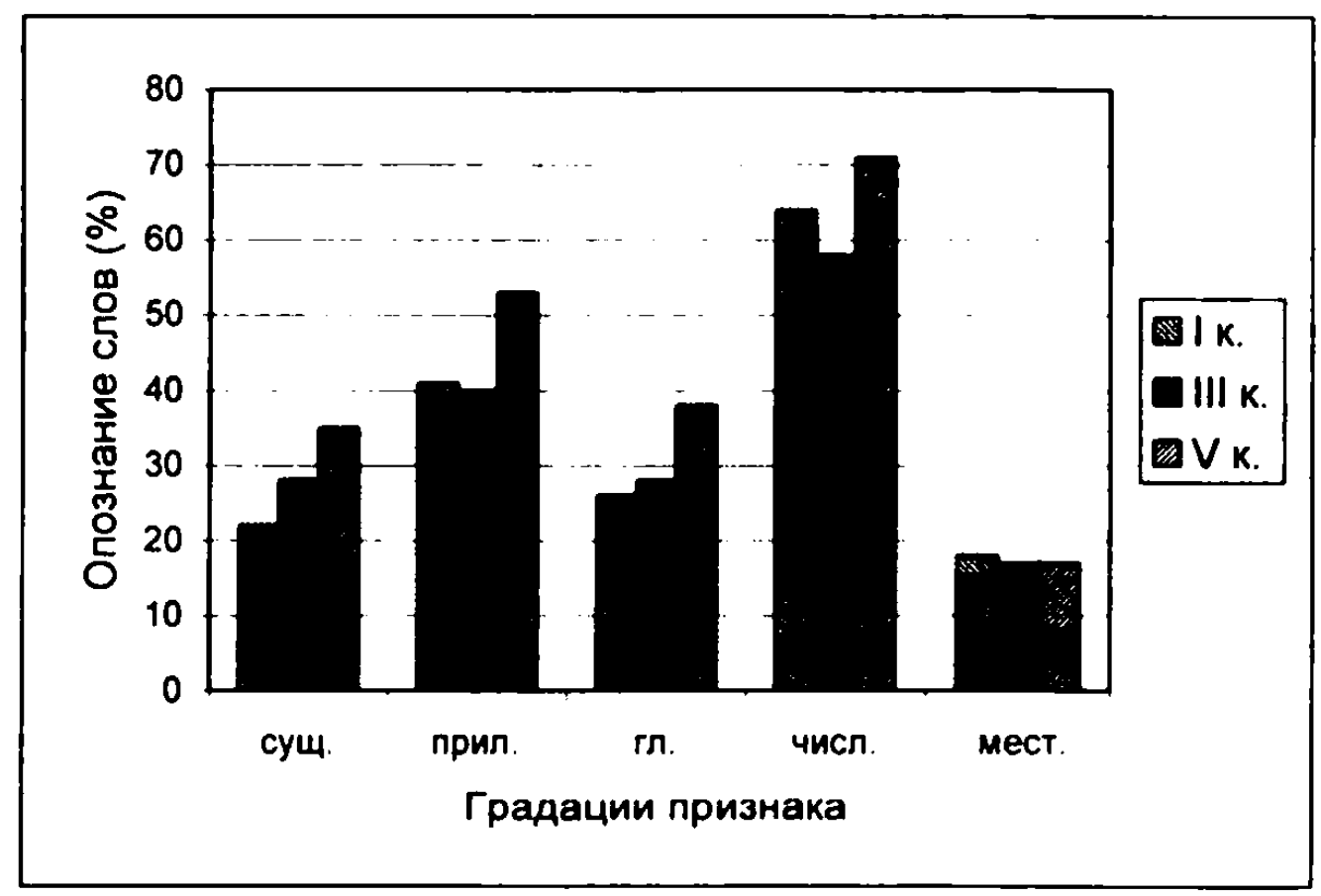

Местоимения опознаются ии. корп. А одинаково плохо, независимо от уровня владения языком. Это объясняется прежде всего их краткостью и отсутствием маркера. Но кроме того, можно предположить, что в силу их деиктического характера появление местоимений в качестве номинации менее вероятно, чем других автосемантических частей речи. Соответственно, установка на них более слабая. 
Рис. 35 6. Опознание признака "часть речи" (корп. A)

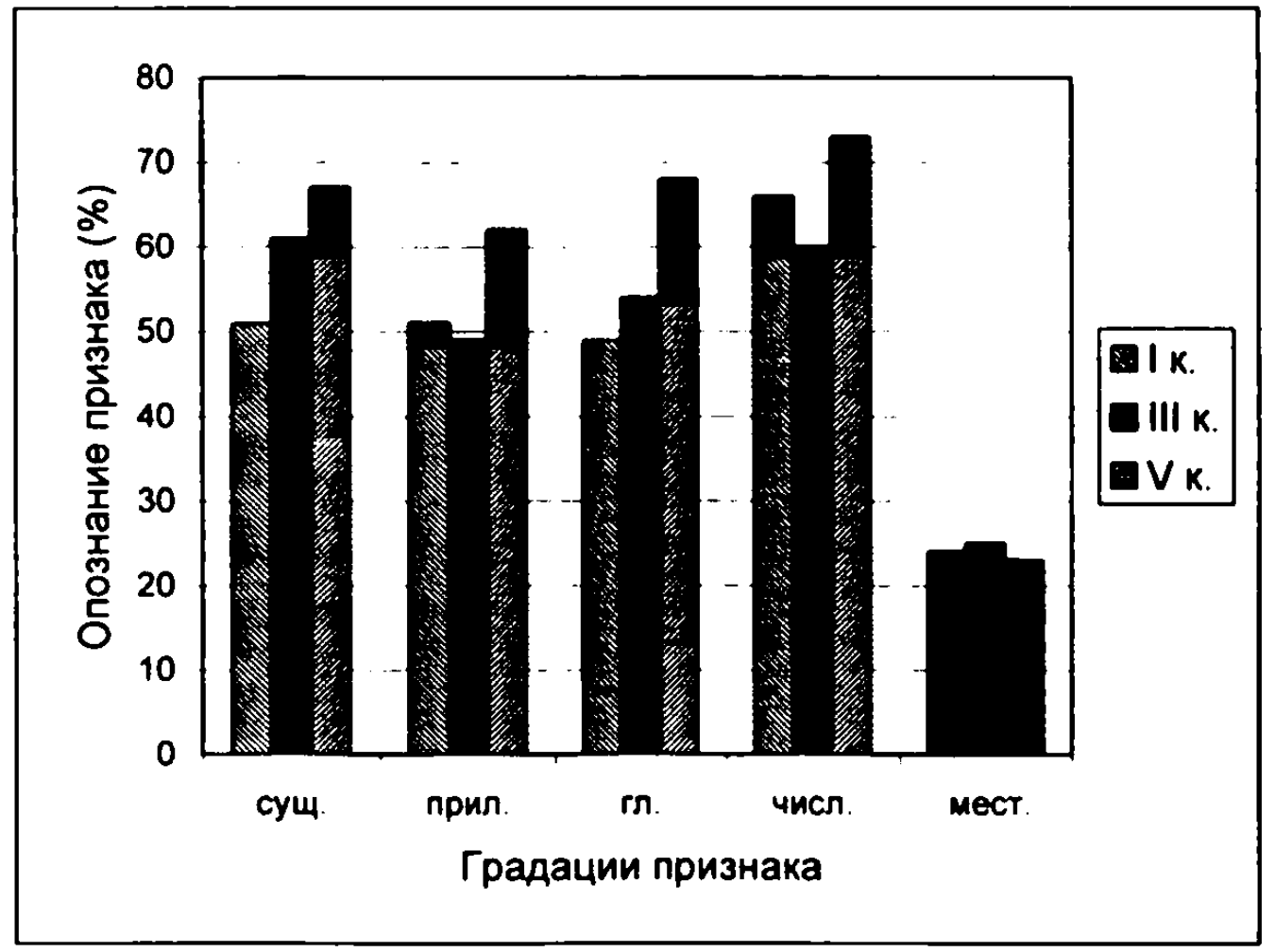

Из рис. 35 а видно, что по мере овладения языком у ии. корп. А улучшается опознание слов отдельных градаций (за исключением местоимений). Особо примечательна эта тенденция для существительных, которые своими окончаниями маркированы неоднозначно. От учашихся требуются более глубокие знания о морфемных структурах изучаемого языка для того, чтобы успешно опираться на те аффиксы, которые характерны для существительных. При этом следует не забывать, что словообразовательные возможности существительных богаче, чем других исследованных частей речи - в том смысле, что в русском языке существует больше именных суффиксов.

Общий вывод следующий: неопределённость элементов слова приводит к ухудшению восприятия. И, наоборот - любая структурная регулярность, осознанная учащимися, повышает вероятность правильного восприятия иноязычной речи. С одной стороны, это подчёркивает значимость прочных знаний в области морфемики изучаемого языка. С другой стороны, это говорит о том, что ориентировка на части слова выражена у иностранцев сильнее, чем у взрослых носителей языка. Она ослабевает по мере овладения языком, о чём свидетельствует снижение $r^{2}$ на III к. и V к.

В целом данные показывают, что морфологический состав слова не более, но и не менее, "чем один из внешних и предварительных опозна- 
вательных признаков той или иной части речи..." [Суник 1966:70], на который опираются аудиторы.

Этот вывод подтверждается при анализе опознания частеречной принадлежности слова ("частеречности"), проведённом на основе всех реакций ии. Рост опознания самой "частеречности" отмечается для всех частей речи, кроме числительных (ср. рис. $35 \mathrm{a}, 6$ ).

Если абстрагироваться от числительных, которые выделяются $3 а$ счёт высокого среднего опознания, то оказывается, что в целом "существительность" воспринимается лучше всего. Кроме того, во всех группах ии. идёт активная замена всех частей речи на имя существительное. Это объясняется тем, что функция номинации при изолированном слове наиболее характерна для существительных.

Но при этом замены на существительное менее характерны для тех частей речи, которые обладают относительно чёткими морфологическими маркерами. Очевидно, слово с неопознанной морфологической приметой вероятнее всего интерпретируется как существительное, для которого нулевой маркер достаточно характерен. Существительные, В свою очередь, заменяются в основном на "глагол".

Анализ "чистых замен" выявляет для немцев корп. А и русских следующую последовательность: С $-Г-П-\mathrm{M}-Ч$.

Таким образом, если изолированное русское слово плохо распознано, то оно с большой вероятностью заменяется на существительное и с минимальной - на числительное. Это показывает, что морфологические, функциональные и, соответственно, частотные характеристики частей речи переплетаются при восприятии изолированных слов.

Факт опоры на значимые элементы слова подтверждается при анализе признака "длина в морфемах". Но как уже отмечалось, на V к. ии. опираются больше на "длину в слогах", чем на "длину в морфемах". Можно предположить, что это связано с некоторым усилением целостной стратегии восприятия.

Из рис. 36 видно, что лучше всего ии. воспринимают слова из двух морфем ${ }^{40}$. Для слов, которые состоят из трёх и более морфем, отмечается ухудшение восприятия.

Эти расчёты были повторены на выверенном по " $F_{06}$ " материале: изъяты лишь высокочастотные слова (градация 1 и 2). Данные предста-

\footnotetext{
${ }^{40}$ Анализ поведения фактора в русском языке был предпрннят на другом словесном материале. Оказалось. что влияние "длины в слогах" сильнее "длины в морфемах" [Бахарева. Краузе. ل1]терн 1985]. Но поскольку фактор "длина в морфемах" не балансировался. конкретные результаты восприятия русских и немцев сравнимы лишь условно. Русские воспринимают слово из двух. трёх. четырёх морфем фактически одинаково. Хуже опознаются одноморфемные слова.
} 
влены в табл. 11,12 . Как видно, они расходятся с результатами общего анализа. Двух - и трёхсложные слова опознаются тем лучше, чем болыше они содержат морфем. Дифференциация результатов восприятия усиливается на высоком уровне владения языком. Наиболее успешно воспринимаются двухсложные слова, состоящие из трёх морфем.

Таблича 11. Зависиность опознания от "длины в слогах" и "длины в.корфемах" (\%) оля высокочастотных слов. Iк. корп. А

\begin{tabular}{|c|c|c|c|}
\hline $\begin{array}{c}\text { Длина в слогах } \\
\text { Длина в морфемах }\end{array}$ & 1 & 2 & 3 \\
\hline 1 & 33 & 37 & - \\
\hline 2 & - & 42 & 33 \\
\hline 3 & - & 61 & 48 \\
\hline
\end{tabular}

Таблица 12. Зависииость опознания от "длины в слогах" и "олины в морфемах" (\%) о.ия высокочастотных слов. Vк. корп. A

\begin{tabular}{|c|c|c|c|}
\hline $\begin{array}{c}\text { Длина в слогах } \\
\text { Динна в морфемах }\end{array}$ & 1 & 2 & 3 \\
\hline 1 & 50 & 44 & - \\
\hline 2 & - & 64 & 48 \\
\hline 3 & - & 82 & 73 \\
\hline
\end{tabular}

Рис. 36. Зависимость восприятие слов от фактора "длина в морфемах" (корп. A)

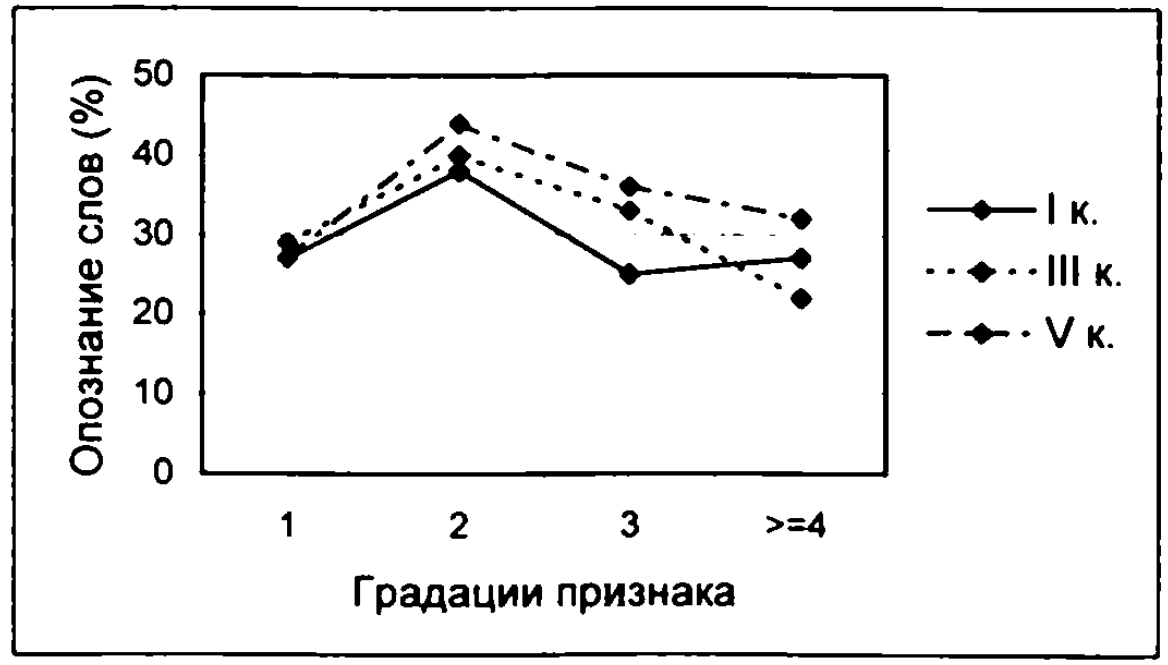

Проанализируем восприятие отдельных видов морфем. На материале немецкого и русского языка обнаружено, что служебные морфемы, которые образуют замкнутые ряды в морфологической и словообразовательной системах языков и характеризуются высокой частотностью, 
воспринимаются лучше корневых морфем [Бахарова, Краузе, Штерн 1985]. Последние отличаются бо́льшим структурным и семантическим многоббразием. Как носители основного лексического значения, они менее частотны, чем те значимые единицы, которые передают более абстрактные лексические и грамматические значения.

Результаты восприятия морфем, которые были получены путём анализа всего массива ответов ии. корп. А, представлены в табл. 13.

Таблица 13. Среднее правильное опознание морфем (\%), корп. A

\begin{tabular}{|l|c|c|c|c|c|}
\hline \multicolumn{1}{|c|}{ Ии. } & I к. & III к. & V к. & P & H \\
Градации & & & & & \\
\hline Префиксы П & 26 & 24 & 39 & 34 & 72 \\
\hline Корни К & 36 & 33 & 47 & 15 & 41 \\
\hline Суффиксы С & 46 & 47 & 61 & 32 & 62 \\
\hline Флексин Ф & 42 & 48 & 56 & 40 & - \\
\hline Постфиксы ПФ & 42 & 50 & 76 & - & - \\
\hline
\end{tabular}

За исключением префиксов, опознание отдельных видов морфем превосходит среднее правильное опознание слов на всех курсах. Это ещё раз подтверждает, что морфемы действительно служат опорой при восприятии слов. Уже Н.И. Жинкин писал, что "в результате той же многократной встречи слов, включаемых в сообщение в разных грамматических формах. эти слова дифференцируются не только на звуковые елиницы (фонемы), но и на специфические единицы более высокого порядка - морфемы" [Жинкин 1988:353]. Осознание морфем ставится в прямую зависимость от языковой компетенции [Кузнецова, Ефремова 1986:8].

Выстроим результаты восприятия в ранговую последовательность:

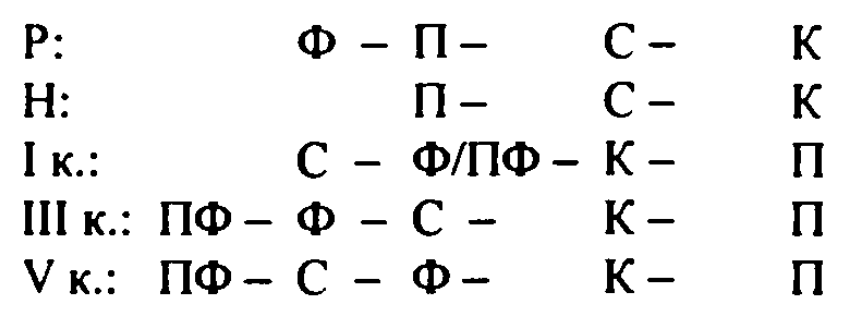

Как видно, значительное влияние на восприятие учащихся оказывает место морфемы в слове. Посткорневые морфемы воспринимаются лучше прекорневых. Это объясняется тем, что наличие внутрисловесного контекста облегчает речевое прогнозирование. Подтверждается, что избыточность информации имеет гораздо больше значения для восприятия в изучаемом, нежели родном языке. 
Особо ярко проявляется роль словесного контекста в восприятии корней. На всех курсах корни в производных словах опознаются лучше слов-корней. Результаты восприятия таковы (табл. 14):

Таб.лица 14. (познание корневых морфем (\%), корп. A

\begin{tabular}{|l|c|c|c|c|c|}
\hline & I к. & III к. & V к. & P & H \\
\hline слова-корни & 27 & 32 & 29 & 10 & 34 \\
\hline $\begin{array}{l}\text { корни в } \\
\text { пронзводных } \\
\text { словах }\end{array}$ & 45 & 34 & 65 & 20 & 47 \\
\hline
\end{tabular}

Восприятие слов-корней практически не улучшается. Но характерно, что особенно на $\mathrm{V}$ к. значительно возрастает опознание корней в производных словах. Безусловно, здесь проявляется возросшая языковая компетенция, лучшая способность к речевому прогнозированию на основе знания морфологических структур изучаемого языка и его лексики."

Начальная позиция префиксов представляет для иностранцев значительные трудности. Нечётко услышанная приставка заменяется любым подходящим префиксом. Например, вместо префикса вы- в слове выходить приводятся приставки на-, про-, за-, при-. По-видимому, в данном случае префикс "приставляется" после того, как слово (или хотя бы корень) прослушаны. Отметим, что восприятие префикса особенно затруднено в случае безударности. Там, где префикс содержит ударный гласный, он чаще опознаётся правильно и замены на другие приставки фонетически не наблюдаются.

Флексии воспринимаются немцами обычно незначительно хуже префиксов. В нашем материале они, как правило, безударны. Это способствует заменам. Например, вместо стимула хороший даются реакции хорошая, хорошие, хороши. По-видимому, ударность/безударность морфем для восприятия в иностранном языке более существенный фактор, чем в родном языке.

На основе имеющихся данных можно предположить, что восприятие морфем носителями языков определяется несколько иными факторами, чем позицией их в слове. Отмечено, например, что в русском языке краевые морфемы - префиксы и флексии - в среднем длиннее суффиксов [Иванов, Новиков 1985:87]. Кроме того, в структуре окончаний

\footnotetext{
${ }^{4}$ Проиллюстрнруем это на конкретном примере. Если на I и III к. вместо стимула мешочничество даются реакции .меще-.., мищо-.., мещ-.., иешу-.., то на $V$ к. появляктся ответы. в которых проявляется соотнесение со словом мешок: мешочек. мешочен, мешочичество. Для всех ия. слово оказалось незнакомым.
} 
преобладают гласные [Зубкова 1988:342], которые более помехоустойчивы, чем согласные. При этом следует учесть, что заударная позиция гласного создаёт для носителей русского языка меньше перцептивных трудностей, чем для немецких учащихся (см. выше, п. 4.5.4).

Прозрачность морфологической структуры слов во многом зависит от характера слого-морфемных стыков. По отношению к русскому языку Н.С. Трубецкой писал ещё в 1934 г., что "в подавляющем большинстве случаев морфемная структура русского слова не может быть автоматически выведена из фонетической формы этого слова. К этому нужно добавить наличие фонетических вариантов отдельных морфем..." [Трубецкой 1987:79]. Кроме тоro, широко распространённая ассимиляция согласных дополнительно осложняет восприятие морфем. ${ }^{42}$ В целом, совпадение границ слога и морфемы мало характерно для русского языка. Оно чаще всего наблюдается на стыке префикса с корнем у глаголов и очень редко на стыке корня или суффикса с флексией в именных образованиях. Равная вероятность как совпадения, так и несовпадения границ допускается на стыках корня с суффиксом или двух суффиксов [Иванов, Новиков 1985:87].

При определении градаций этой характеристики слова мы должны были определить свой подход к слогоразделу в русском языке. Мы решили исходить из того, что "любая последовательность типа СГССГ распадается на две произносительные единицы следующим образом: СГ-ССГ" [Бондарко 1977:134]. ${ }^{43}$

По сравнению с родным языком ии., влияние признака в МО групп корп. А невелико (табл. 9). ${ }^{44}$ Как фактор более высокого лингвистического уровня, он располагается в последней трети факториальной иерархии. На I и III к. лучше всего воспринимаются те слова, которые обладают одним совпадающим стыком. И лишь на высоком уровне владения языком проявляется прямая зависимость между опознанием слов и градациями данного фактора (рис. 37). Но поскольку слого-морфемные

\footnotetext{
42 Это пример того, что артикуляционная простота или "естественность", как говорят сторонники концепции натуральной фонологии, находится в постоянном противооорстве с перцептивной определённостью функциональных элементов языка (морфем) [Wurzel 1984:30].

${ }^{43}$ Дополнительно проводилось исследование на основе тратиционного артикуляторного подхода Л.В. Щербы, который связывает слогораздел с ударением [Зиндер 1979; Бондарко. Вербицкая. Гордина 1983]. Оказачось. что способ разбиения гра:аций не влияет на результаты восприятия существенным образом. Тенденции совпадают полностью. Разница в том, что при традиционном подходе в ряде случаев $\mathrm{r}^{2}$ становится несушественным и несколько уменышается.

औ Напомним, что по техническим причинам восприятие фактора русскими анализировалось только при соотношении $\mathrm{S} / \mathrm{N}=0$ дБ.
} 
стыки маркированы в русском языке менее чётко и фактор не балансировался, этот результат вероятнее всего обусловлен другими факторами - в частности, "длиной в слогах".

Рис. 37. Восприятие слов в зависимости от количества слого.иорфемных стыков (корп. A)

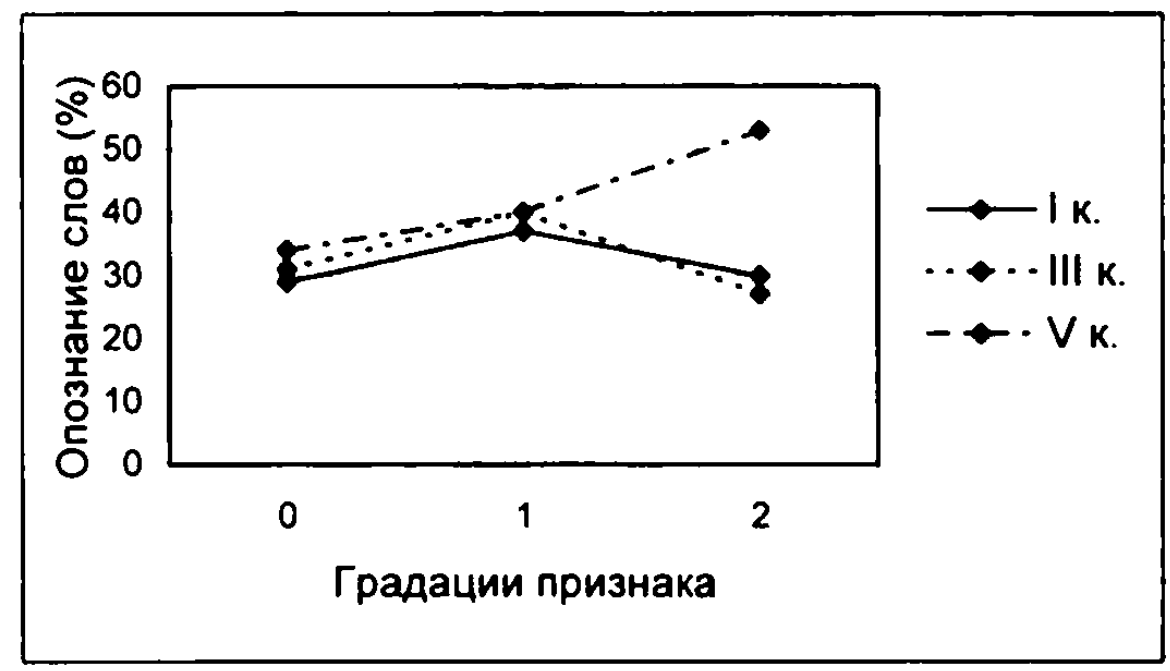

Итак, анализ факторов морфемного уровня позволяет утверждать, что аудиторы не только в родном, но и в изучаемом языке опираются на морфемы как значимые элементы слов. Но поскольку русское слово структурировано менее чётко, чем немецкое слово, фактор "количество слого-морфемных стыков" уходит на задний план.

\subsection{6 Признаки фонемного уровня}

Известно, что ударные гласные относятся к наиболее помехоустойчивым характеристикам слова [Зиндер 1951; Лущихина 1965]. Поэтому интересно рассмотреть, насколько восприятие слова определяется фонемной принадлежностью ударного гласного.

На младших курсах корп. А признак "ударная гдасная фонема" не существен по F-критерию (табл. 9). Только на V к. происходит скачок на более передний ранг. Это оценивается как сближение с МО носителей русского языка, в котором "ударная гласная фонема" занимает второе поле "длины в слогах" место. Но в целом роль фактора в МО иностранцев ниже, чем в $\mathrm{MO}$ носителей языка. Этот вывод подтверждают данные по восприятию немецких и английских слов русскими [Акопян 1985; Чугаева 1989]. 
Выстроим результаты восприятия градаций по нисходящему опонанию (ср. рис. 38 a) $)^{45}$ :

І к.: $\quad \mid \mathrm{y} /-/ \mathrm{e} /-/ \mathrm{i} /-/ \mathrm{a} /-/ \mathrm{o} /-/ \mathrm{u}$;

III к.: $/ \mathrm{a} /, / \mathrm{y} /, / \mathrm{e} /-/ \mathrm{o} /-/ \mathrm{w}-/ \mathrm{i} /$;

Vк.: $/ \mathrm{a} /-/ \mathrm{e} /-/ \mathrm{w} / \mathrm{lo} /-/ \mathrm{y} /-\mathrm{i} /$;

P: $\quad / \mathrm{a} /-/ \mathrm{o} /-/ \mathrm{e} /-/ \mathrm{i} /-/ \mathrm{w} /-/ \mathrm{y} /$.

Козффициент корреляции с рядом носителей русского языка растёт от $\rho=-0,31$ на I к., $\rho=0,26$ на III к. до $\rho=0,60$ на $\mathrm{V}$ к. Но в целом из этих данных вытекает, что фонемная принадлежность ударного гласного играет в восприятии русских слов немцами скорее второстепенную роль. Например, хорошее опознание слов с ударной фонемой /y/ не объяснимо фонетически, поскольку сама фонема /y/ воспринимается достаточно плохо на всех курсах (см. ниже, рис. 38 б). Здесь действуют скорее лексические причины. Лишь на $V$ к. вырисовывается определённая зависимость восприятия слов от интенсивности ударных гласных: /a/ более интенсивно чем / $/ \mathrm{d} / \mathrm{a} / \mathrm{w} /$ превосходит /i/ [Жинкин 1958:178].

Рис. 38 а. Зависимость восприятия слов от ударной гласной фонемы (корп. A)

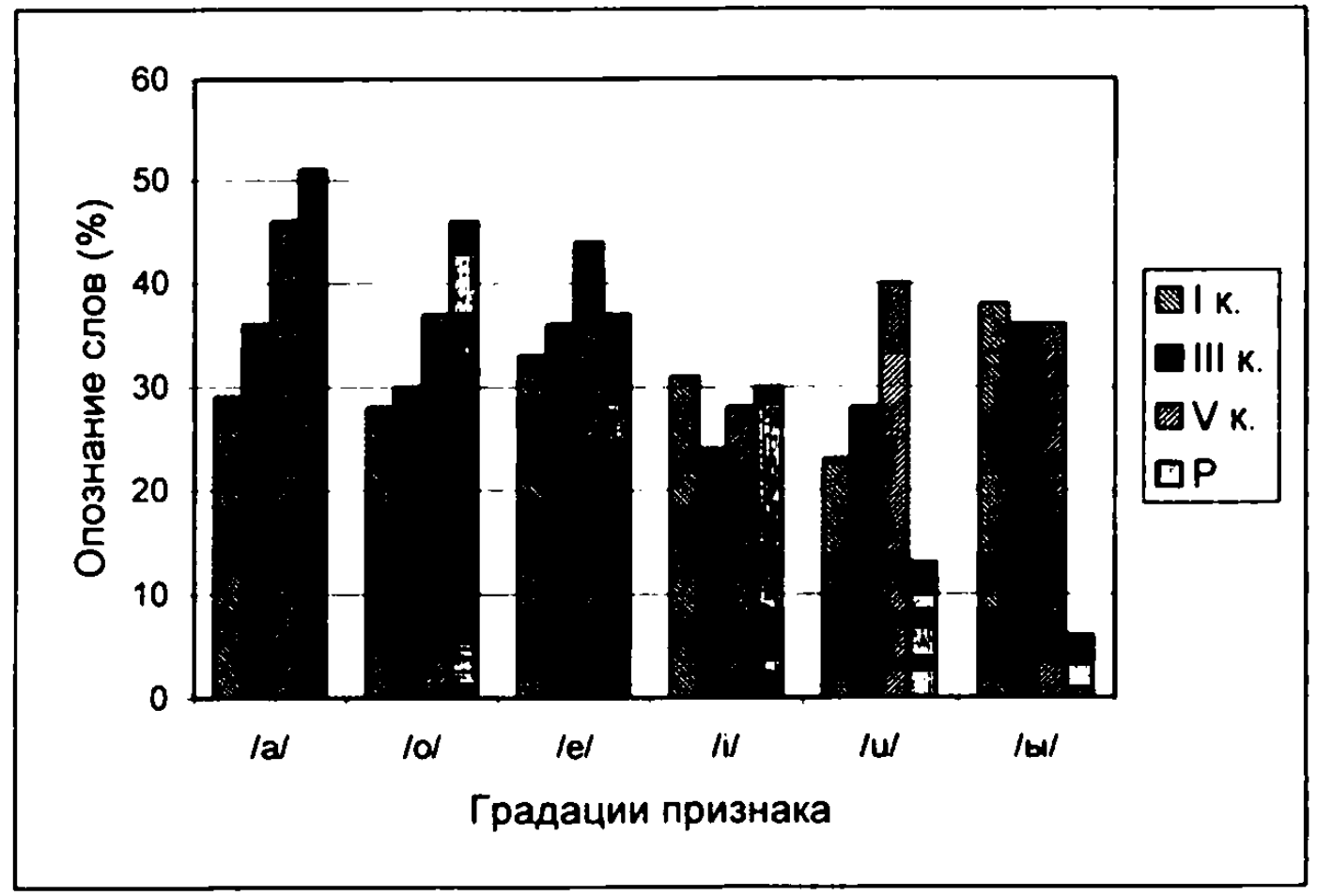

45 В графиках русская фонема /y/ обозначается русской графемой /ы/. 
Рис. 38 6. Правильное опознание признака" ударная гласная фонема" (корп. A)

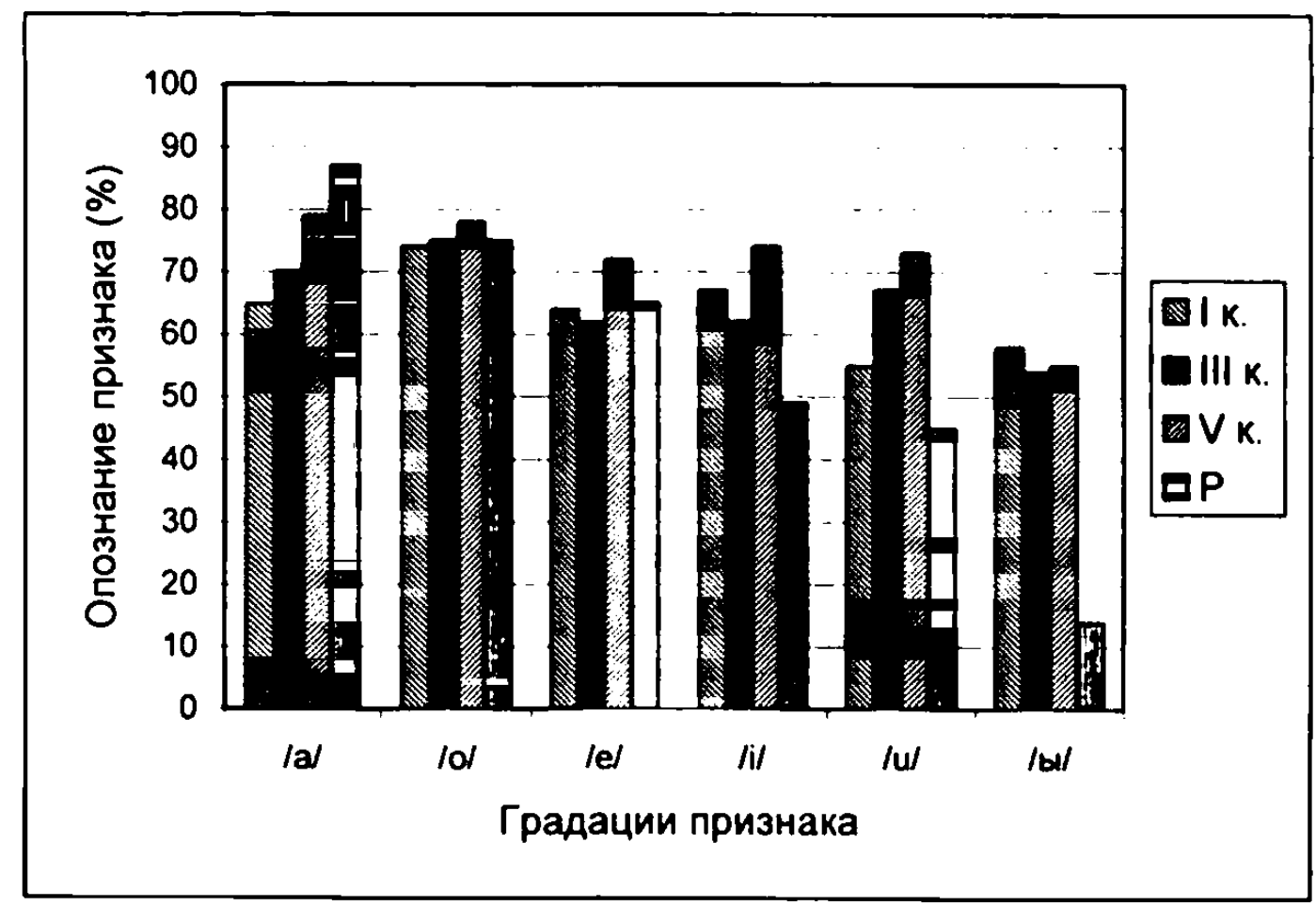

Анализ правильного восприятия самих ударных гласных выявляет следующие нисходящие последовательности (рис. 38 б):

$\begin{array}{ll}\text { I к.: } & / \mathrm{o} /-/ \mathrm{i} /-/ \mathrm{a} /, / \mathrm{e} /-/ \mathrm{y} /-/ \mathrm{w} / \\ \text { III к.: } & / \mathrm{o} /-/ \mathrm{a} /-/ \mathrm{w} / / \mathrm{i} /, / \mathrm{e} /-/ \mathrm{y} / \\ \text { V к.: } & / \mathrm{o} /, / \mathrm{a} /-/ \mathrm{i} / / \mathrm{w} /, / \mathrm{e} /-/ \mathrm{y} / ; \\ \text { P: } & / \mathrm{a} /-/ \mathrm{e} /-/ \mathrm{o} /-/ \mathrm{i} /-/ \mathrm{w} /-/ \mathrm{y} / .\end{array}$

Расчёт коэффициентов ранговой корреляции с опознанием ударных гласных русскими показывает, что по мере овладения языком немцы воспринимают всё более соотносимо с носителями русского языка: $\rho_{l}=0,47$, $\rho_{\mathrm{III}}=0,56, \rho_{\mathrm{v}}=0,79$. Это говорит об упрочении перцептивных эталонов в сознании учащихся. Результаты восприятия русских объясняются прежде всего интенсивностью и частотой встречаемости гласных.

Обратимся к анализу замен ударных гласных (рис. 39). Если русские ии. заменяют гласные в основном по ряду, то у немецких учащихся преобладают замены по подъёму. Замены по ряду характерны лишь для фонемы /y/. Отчасти это обусловлено дифтонгоидным характером /y/. Соответственно, замены на $/ \mathrm{i} /$ и /w наблюдаются и у русских ии. Но восприятие /e/ и /o/ вместо /y/ у них практически не встречается. Значит, вплоть до высокого уровня владения русским языком учащиеся испы- 
тывают трудности в опознании /y/. По-видимому, перцептивный эталон фонемы сформирован всё ещё недостаточно прочно.

Рис. 39. Типичные замены ударных гласных а) у немцев в немечком языке. б) у немцев в русском языке, в) у русских в русском языке

Puc. 39 a.

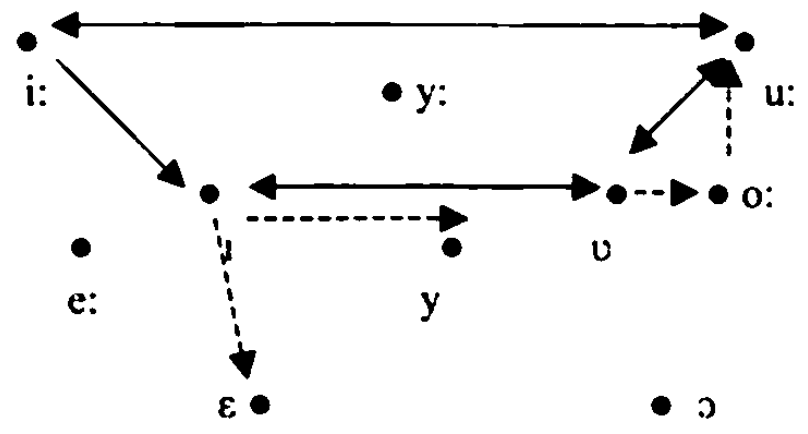

Puc. 396.

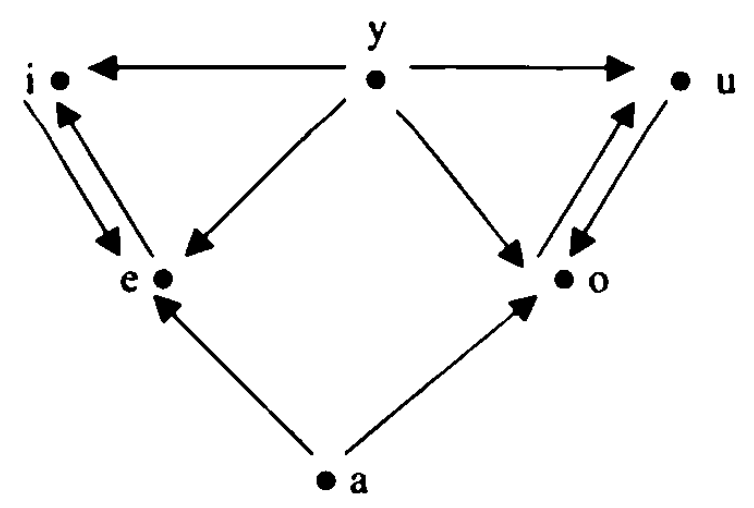

Puc. 39 в.
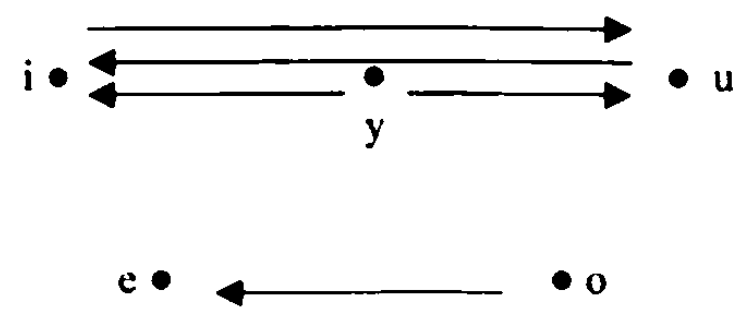
По подъёму русские гласные фонемы расположены между соответствующими немецкими долгими и краткими гласными [Meinhold, Stock 1982:105]. Кроме того, краткие передние гласные немецкого языка реализуются заднее, чем соответствующие долгие гласные. При анализе замен следует также учесть, что по новым экспериментальным данным немецкие /e:/ и /1/, а также /o:/ и /v/ артикуляторно и акустически достаточно сходны [Sendlmejer 1981; Hentschel 1986]. Они различаются прежде всего количественно. Всё это вместе создаёт благоприятные условия для гипердифференциации русских гласных под воздействием системы гласных родного языка ии. Показательно, что она реализуется преимущественно после мягких согласных. Насколько характер замен связан с длительностью русских ударных гласных, не могло быть установлено, поскольку соответствующие данные для русского языка неоднозначны (ср. [Бондарко 1981:159]).

Итак, характер замен указывает на то, что особенно в позиции после мягких согласных опознание ударного гласного представляет трудности. В этом плане студенты не могут опираться на опыт родного языка. В процессе обучения языку соответствующие эталоны должны быть сформированы заново. Они, видимо, менее прочны, менее помехоустойчивы, чем ранее усвоенные и достаточно закреплённые перцептивные эталоны, что и приводит к интерференции родного языка.

Из табл. 9 видно, что среди всех признаков, характеризующих слово фонетически, фактор "консонантный коэффициент" является ведущим. Следует указать на то, что фактор не является совершенно самостоятельным лингвистическим признаком: высокий консонантный коэффициент характерен прежде всего для более кратких слов, и наоборот. Это подтверждается и в нашем русском материале ${ }^{46}$ : на консонантный коэффициент $0<k \leq 1$ приходится $48 \%$ слов, состоящих из четырёх и более слогов. Из односложных слов $74 \%$ попадает в интервал $2<\mathrm{k} \leq 3$.

Но тем не менее признак "консонантный козффициент" действует относительно автономно. Это проявляется как в различных для факторов "консонантный коэффициент" и "длина в слогах" значениях $\mathrm{r}^{2}$, так и в различной динамике обонх признаков внутри ранговых порядков. Об этом также свидетельствуют конкретные результаты восприятия. К примеру, вплоть до $\mathrm{V}$ к. слова с $2<\mathrm{k} \leq 3$ воспринимаются немецкими ии. хуже односложных, между тем как слова, попадающие в интервал $0<\mathrm{k}$ $\leq 1$, опознаются лучше трёх- и четырёхсложных слов.

Таким образом, начиная с I к., ии. проявляют ту же тенденцию, что и носители языка: чем меньше согласных приходится в слове на один

th Напомним. что матернал не сбаланснрован по этому признаку. 
гласный, тем лучше его воспринимают (рис. 40). Правда, данная зависимость выступает в восприятии немецких слов немцами менее ярко - ср. рис. 18. С одной стороны, результаты можно объяснить различной устойчивостью гласных и согласных к белому шуму. Вероятность того, что слова с относительно большим количеством согласных маскируются помехой сильнее слов с меньшим консонантным коэффициентом, достаточно высока. А с другой стороны, в поведении этого фактора проявляется речевой опыт и сопряжённая с ним способность к вероятностному прогнозированию. Уже отмечено, что немецкий язык более консонантен, чем русский. Это подтверждается анализом типичных типов слогов. В русском языке господствует открытый слог [Бондарко 1981], в то время как он в немецком языке выступает лишь в $33 \%$ всех слогов [Esser 1960:70]. Наиболее распространённым слоговым типом немецкого языка является структура СГС (44\%) [там же : 71 ].

Поэтому можно предположить, что поведение фактора отражает степень адаптации к несколько другой структуре слов в изучаемом языке. Очевидно, нахождение в среде носителей языка оказывает на этот процесс немаловажное влияние.

Рис. 40. Восприятие слов в зависимости от консонантного козффициента (корп. A)

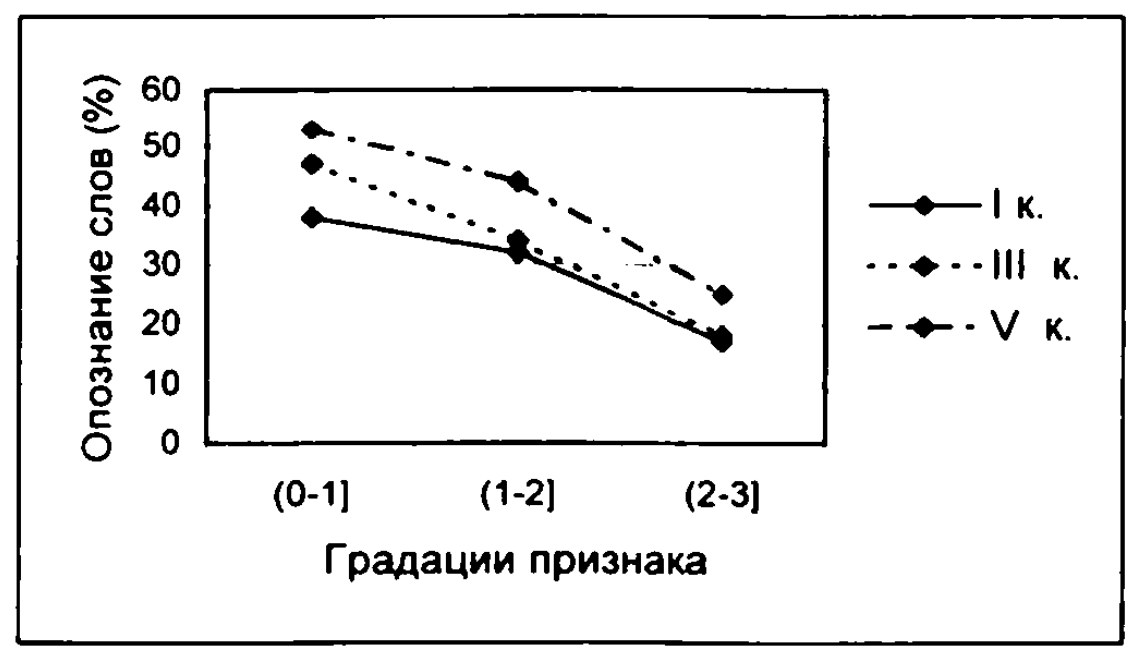

Значительно слабее, чем предыдуший признак, действует фактор "количество консонансов" (табл. 9). Кроме того, роль признака падает при переходе к старшим курсам.

Студенты I и III к. опознают лучше всего те слова, которые не содержат консонантных сочетаний (рис. 41 ). Только V к. опирается более успешно на этот фактор: слова с двумя и более консонансами воспринимаются лучше других градаций. Сравнение с данными носителей рус- 
скго языка показывают, что дифференциация результатов восприять слов без консонансов и с двумя и более консонансами проявляется немцев V к. менее ярко (разность у русских - $15 \%$ у У к. $-6 \%$ ).

\section{Pис. 41. Восприятие слов в зависимости от количества консонансов (корп. A)}

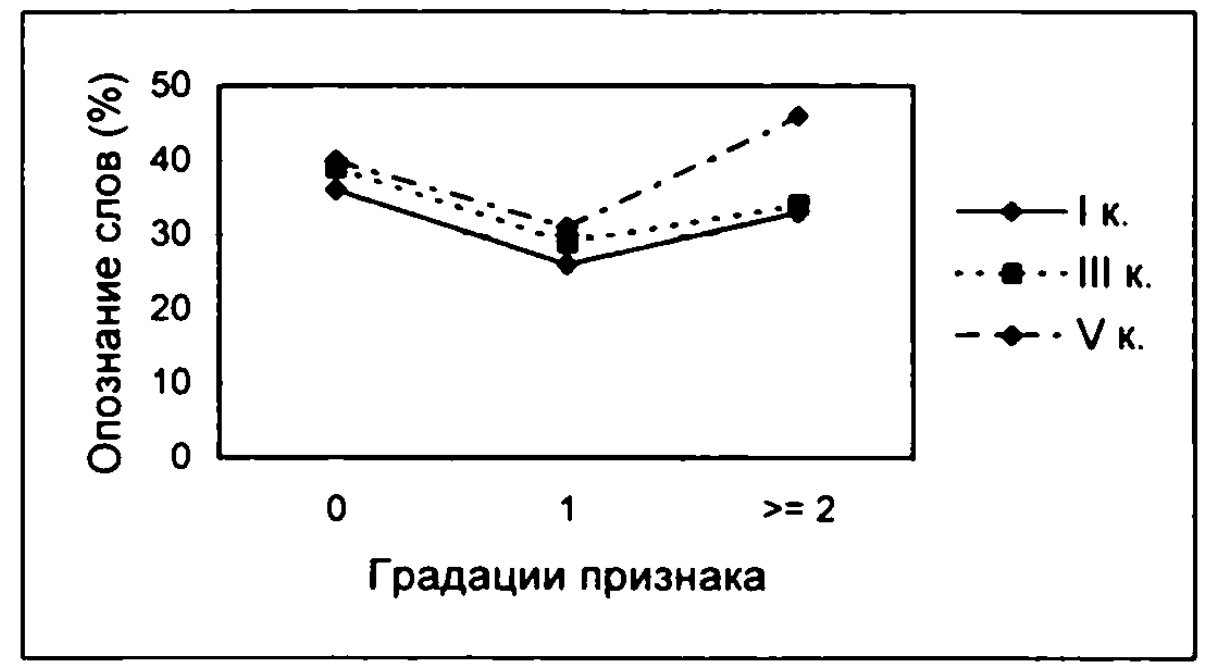

При оценке фактора следует также учесть, что на всех курсє слова с одним консонансом опознаются хуже слов других градаци: Противоречивость данных приводит к мысли о том, что результат восприятия обусловлены не столько исследуемым признаком, сколы действием других, более значимых факторов. Причину этого А.С. Штеғ видит в квазиомонимии, т.к. слова с двумя консонансами обладак меньшим количеством квазиомонимов [Штерн 1981:68]. Очевидно, рол играет и длина слов.

Обратимся ещё к фактору "начальный звук". В МО ии. корп. этот признак относится к наиболее слабым (табл. 9). Подтверждаетс вывод, ранее сделанный для восприятия носителями русского и неме ого языков: принадлежность начального звука к гласным и согласным ғ имеет существенного значения для опознания слов.

\subsection{7 Дифференциальные признаки}

Роль дифференциальных признаков (ДП) в МО немцев корп. А очег незначительна (табл. 9). Следует отметить, что опора на ДП очень слаб выражена во всех механизмах восприятия слов, исследованных по да। ной методике. Подтверждается, что признаки более низкого лингвист। ческого уровня отодвигаются на задний план при восприятии едини более высокого уровня (ср. [Ломов 1966:354]). Это можно оценить ка некоторую универсалию восприятия речи. 
Русские аудиторы опираются, хотя и слабо, на признаки "твёрдость-мягкость" и "смычность - щелевость", в то время как для немецких ии. корп. А существенными являются факторы "твёрдость - мягкость" и "звонкость - глухость".

Некоторая опора на признак "звонкость - глухость", которая не имеет места у носителей русского языка, можно трактовать как интерференцию родного языка ии. Напомним, что на материале немецкого языка установлено, что ДП и в особенности факторы "звонкость - глухость" и "фортисность - ленисность" усиливают своё влияние в очень трудных условиях восприятия. Между тем, было бы также интересно посмотреть, как ведёт себя фактор "звонкость - глухость" в более трудных условиях восприятия русских слов русскими.

Статистическая существенность ДП может проявляться в результате хорошего опознания слов смешанной градации. Это имеет место для признака "звонкость - глухость", крайние градации которого воспринимаются немцами корп. А примерно одинаково (рис. 42). Отметим, что тенденция $\kappa$ лучшему опознанию серединной градации наблюдается также в несущественных для ии. корп. А ДП. Она проявляется и в восприятии русских слов русскими, правда, только в лёгких условиях приёма.

Рис. 42. Зависимость восприятие слов от признака "звонкость - глихость" (корп. A)

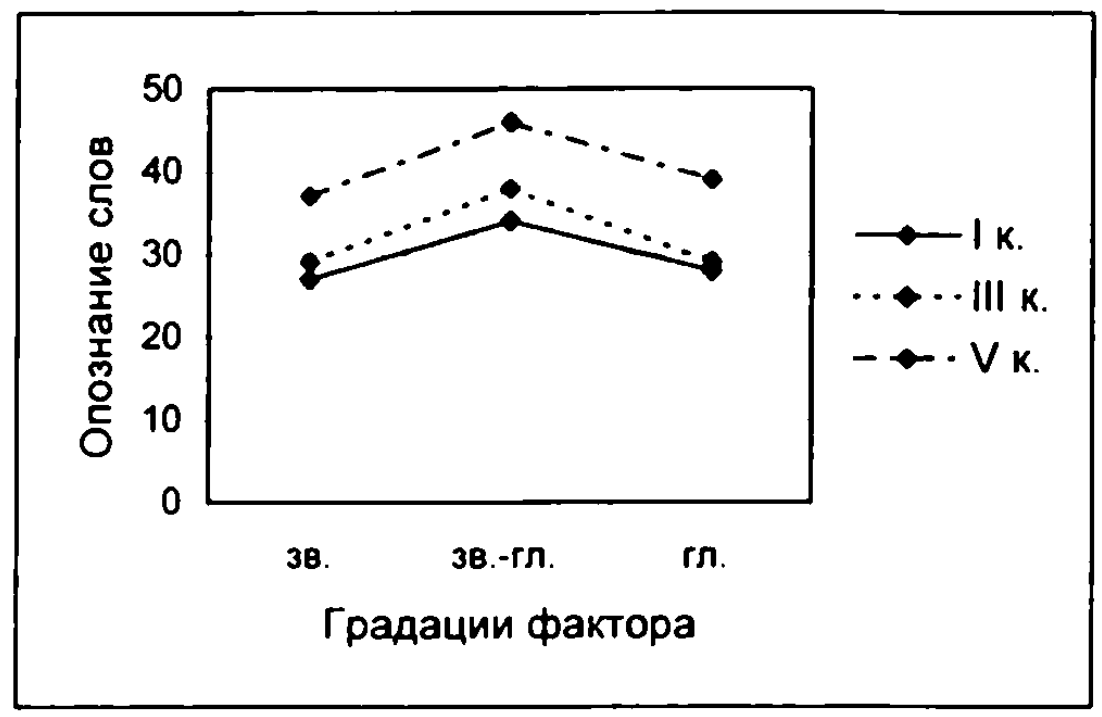

Поскольку слова смешанной градации содержат члены определённой фонологической оппозиции в примерно одинаковом количестве, они характеризуются максимальной контрастностью входящих в них согласных. Но из психологии известно, что в одинаковых условиях предъ- 
явления лучше воспринимаются те стимулы, которые непохожи один на другой, между тем как похожие или тождественные стимулы тормозят друг друга (феномен Раншбурга - cp. [Juhász 1970:93]). Для зрительного восприятия установлено, что этот феномен наблюдается как при одновременном, так и при последовательном предъявлении стимулов [Шехтер 1981:34]. В слуховом восприятии положительная роль контраста проявляется, например, при маскировке звуковых сигналов тональной помехой [Справочник по инженерной психологии 1982:72]. Она также обнаруживается при восприятии слогов: как правило, их опознание растёт по мере нарастания слогового контраста [Бондарко 1974:24]. Следовательно, можно утверждать, что контрастность входящих в целое (слово) элементов (согласных) способствует опознанию стимулов.

Остановимся ещё на признаке "твёрдость - мягкость", который представляет особый интерес, поскольку в родном языке ии. отсутствует фонологическая оппозиция по твёрдости - мягкости.

Начиная с I к., учащиеся корп. А оперируют перцептивным признаком "твёрдость - мягкость" на том же уровне, как носители языка. Что же касается опознания слов отдельных градаций, то здесь обнаруживаются различия между русскими и немцами (рис. 43,44 ): русские аудиторы опознают более успешно те слова, которые содержат в основном твёрдые согласные. Это объясняется тем, что информация о твёрдости приходится в основном на низкочастотную часть спектра, коорая маскируется белым шумом меньше, чем высокие частоты. Кроме того, твёрдые согласные как немаркированные члены оппозиции встреаются в русской речи в два раза чаще, чем мягкие [Фонетика спонтанной речи 1988:2 13]. Но отметим, что в более лёгких условиях приёма $(\mathrm{S} / \mathrm{N}=$ 0 дБ) русские ии. лучше всего опознают слова смешанной градации [Штерн 1981].

Из рис. 43 видно, что ии. I к. корп. А лучше опознают те слова, в которых преобладают мягкие согласные. ${ }^{47}$ На старших курсах выравниваются результаты восприятия крайних градаций. Одновременно наблюдается чёткая тенденция к лучшему восприятию смешанной градации.

\footnotetext{
47 Учитывая известные артикуляционные трудности в реализации мягких согласных немцами, хорошее восприятие слов с преобладанием палатализованных подтверждает опережающиий характер восприятия (ср. [Джапаридзе 1985:201]).
} 
Рис. 43. Зависииость восприятие слов от признака "твёрдость-мягкость" (корп. A)

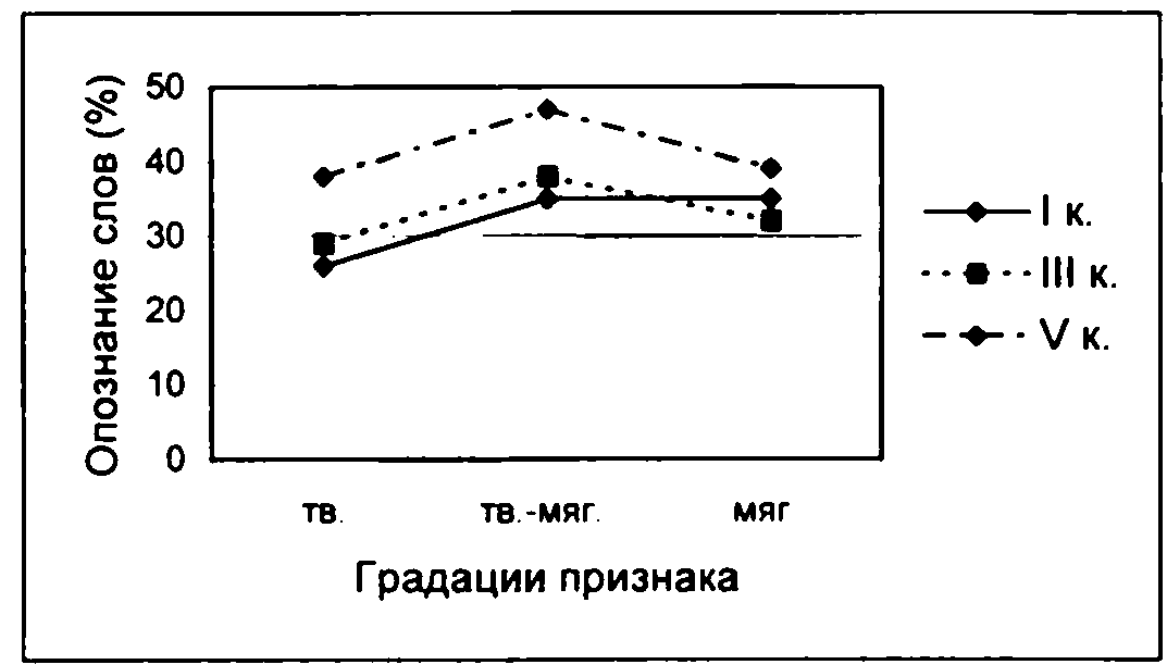

Pис. 44. Зависимость восприятие слов от признака "твёрдость - мягкость" (P)

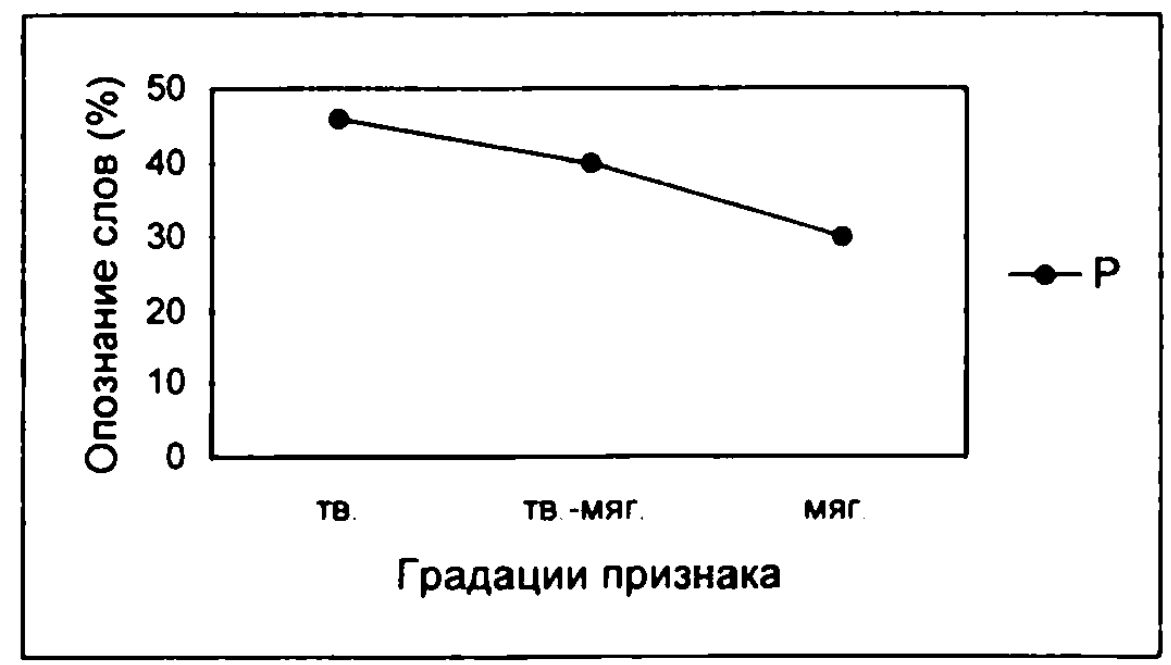

Высокое опознание слов с преобладанием мягких согласных на I к. акустически не объяснимо. На наш взгляд, в данном случае проявляется опять феномен контраста. Можно предполагать, что услышанные ии. стимулы достаточно отличны от тех эталонов, которые существуют в памяти ии. І к. И с которыми они пытаются производить еличение. При этом контрастность может иметь место как по отношению $к$ перцептивной базе родного языка, так и по отношению к той перцептивной базе, которая сложилась у ии. в итоге школьного обучения русскому языку. Следует отметить, что правильной артикуляции мягких согласных русского языка в школе уделяется очень мало внимания. Это 
часто приводит к тому, что вместо мягкого согласного русского языка произносится согласный немецкого языка плюс /j/.

По мере накопления речевого опыта в среде носителей языка создаются правильные перцептивные эталоны. Контрастность мягких согласных исчезает. При этом мы отдаём себе отчёт в том, что противопоставление по твёрдости - мягкости характеризует не столько сам согласный, сколько целый слог [Бондарко 1977]. Но ясно, что соответствующие перцептивные эталоны (возможно, как на уровне отдельных звуков, так и на уровне слогов) должны быть усвоены. Специальный эксперимент по восприятию русских твёрдых и мягких согласных иностранцами показал, что ии. вполне в состоянии различать твёрдость и мягкость при парном предъявлении, между тем как опознание конкретных фонем представляет значительные трудности [Интерференция звуковых систем 1987:200].

Перцептивные эталоны твёрдых согласных сформированы более точно. Можно предположить, что немецкие согласные и твёрдые русские согласные создают зоны перцептивного сходства (ср. [Джапаридзе 1985: 53]). 


\section{5. ВОСПРИЯТИЕ РУССКИХ СЛОВ НЕМЦАМИ (КОРПУС Б)}

\section{1 Характеристика испытуемых}

Вторая часть эксперимента была проведена среди будущих учителей русского и английского языков, которые учились в университете им. Ф. Шиллера г. Йена. Специально подбирались сильные студенческие группы. I к. обучения представлен 22 ии., II к. - 8. Следует отметить, что студенты I к. проходили корректировочный курс по фонетике (15 часов). Эксперимент на III к. (12 ии.) был проведён через месяц после того, как студенты вернулись с шестимесячной стажировки в Москве. Другая часть ии. училась в течении всего III к. (10 месяцев) в Минске ${ }^{48}$. В этой группе (15 ии.) эксперимент состоялся уже на IV к., примерно 4 месяца после возвращения из Белоруссии. За этот период у ии. практически не было речевой практики на русском языке: после каникул на IV к. занятиям по русскому языку отводилось всего два часа в неделю.

Для этого корпуса ии. проанализировано 8850 реакций.

\section{2 Общие результаты восприятия}

Характер реакций испытуемых корпуса Б и их количественное соотношение прелставлены в табл. 15.

Таблича 15. Общие результаты восприятия ии. корпуса Б (\%)

\begin{tabular}{|l|c|c|l|l|l|l|c|}
\hline Курс & \multicolumn{2}{l|}{$\begin{array}{l}\text { Среднее } \\
\text { правильное } \\
\text { опознание } \\
\bar{x}\end{array}$} & $\begin{array}{l}\text { Неправильные } \\
\text { словесные } \\
\text { реакция }\end{array}$ & $\begin{array}{l}\text { Словесные } \\
\text { реакция в } \\
\text { целом }\end{array}$ & $\begin{array}{l}\text { Квазн- } \\
\text { слова }\end{array}$ & $\begin{array}{l}\text { Прочие } \\
\text { реакция }\end{array}$ & Отказы \\
\hline I & 30 & 3,6 & 34 & 64 & 16 & 9 & 11 \\
\hline II & 36 & 2.8 & 25 & 61 & 8 & 10 & 21 \\
\hline III & 38 & 4.2 & 38 & 76 & 8 & 6 & 10 \\
\hline IV & 38 & 4.8 & 38 & 76 & 8 & 8 & 8 \\
\hline
\end{tabular}

Среднее правильное опознание слов растёт до III к. и остаётся стабильным на IV к. Почти то же самое наблюдается для неправильных словесных реакций. ${ }^{49} 3$ начит, так же, как в группах корп. А, наибольшее

\footnotetext{
${ }^{48}$ Языком обучения и общения во время стажировки в Белоруссии был русский.

${ }^{49}$ Ии. II к. скорее готовы дать отказ на неточно услышанное слово, чем подобрать другое слово, хотя инструкция эксперимента во всех группах была одинаковой.
} 
количество словесных реакций встречается на старших курсах. Это объясняется тем, что студенты III и IV к., с одной стороны, могут опираться на возросший лексический запас и, с другой, на лучшую способность соотнести услышанное со знакомым им словом.

Вместе с тем, ожидалась некоторая дифференциация результатов восприятия в зависимости от срока стажировки в языковой среде. Но студенты III и IV к. опознают слова в тождественных условиях примерно одинаково. Тем не менее мы рассмотрим их механизм восприятия раздельно.

Данные корп. Б сопоставимы с результатами восприятия при включённом обучении лишь на уровне тенденций, потому что эксперименты были проведены в различных условиях. Для параметров "квазислова" и "прочие реакции" в корп. А наблюдается более чёткий спад при переходе к старшим курсам, чем это имеет место у ии. корп. Б.

Обратимся к более детальному анализу ответов ии. Реакции на знакомые студентам и достаточно частотные стимулы содержат графические ошибки довольно редко. Более частотны они в ответах на незнакомые или, видимо, недостаточно закреплённые слова, когда ии. из-за отсутствия эталона в памяти, вынуждены прибегать к более дробному фонетическому анализу. ПТо своему характеру эти ошибки в основном обусловлены фонетической интерференцией родного языка. В частности, наблюдается недодифференциация /z/ и /s/, особенно в начальной позиции $(/ \mathrm{z} /$ заменяется на $/ \mathrm{s} /)$. Трудности наблюдаются также в различии $/ \mathrm{d} /$ и $/ \mathrm{d}, / \mathrm{p} /$ и $/ \mathrm{b} /$, причём не только в начальной, но и в интервокальной позиции.

Особенно ярко проявляется недодифференциация русских шипящих как по способу образования, так по твёрдости - мягкости и по звонкости - глухости.

Отметим, что все эти ошибки характерны для артикуляции немцев в русском языке [Wiede 1981; Müller 1984; Schindler 1987]. Следовательно, они отражают не столько графические трудности в передаче услышанного, сколько реальную фонетическую интерференцию, которая сказывается и при восприятии.

О.А. Нехай и Т.В. Поплавская предлагают различать интерференцию в узком смысле, которая обозначает уподобление первичному эталону (это имеет место в случае замен $/ \mathrm{z} /-/ \mathrm{s} /, / \mathrm{b} /-/ \mathrm{p} /, / \mathrm{d} /-/ \mathrm{t} /$ ), и интерференцию в широком смысле слова [Нехай, Поплавская 1983]. Последняя подразумевает отклонение от эталонов второго языка, что, на наш взгляд, является следствием недостаточно прочной их сформированности. Это мы наблюдаем в восприятии русских шипящих. Родной язык действует в данном случае косвенно, мешая становлению новых 
перцептивных эталонов: во-первых, он преобладает в речевой практике учащихся, которые лишь несколько часов в неделю в какой-то степени находятся под влиянием артикуляции и восприятия на другом языке. Вовторых, при обучении иностранному языку "школьным" методом затрудняется формирование адекватных перцептивных эталонов ещё потому, что в речи преподавателя обычно не исчезает акцент. Это может привести к формированию особой, третьей перцептивной базы [Чугаева, Штерн 1989:69].

Итак, перцептивные ошибки отражаются в основном в незнакомой или недостаточно закреплённой лексике. В то же время сомнительно, чтобы фонетические трудности проявлялись лишь при восприятии незнакомых слов. Имеются все основания считать, что при восприятии знакомых и хорошо закреплённых слов они лишь подавляются. Знакомое имеет в сознании некоторый коррелят (эталон), и опознание реализуется скорее целостным отождествлением стимула с этим коррелятом [Шехтер 1981:17 посл.]. Предполагается, что в памяти сохраняются как слуховые, так и зрительные эталоны слов [Zimmer 1985:284]. Тот факт, что студенты делают мало орфографических ошибок в передаче знакомых слов, говорит о прочности зрительных эталонов. Это неудивительно, поскольку на занятиях по русскому языку новое слово обязательно вводится графически. Соответственно, учащиеся запоминают эту форму репрезентации, просто выучивают её. Поэтому принимается, что зрительные образы способны в определённой степени довлеть над конкретно услышанными, корректируя его и компенсируя тем самым перuептивные трудности.

О6 относительной автономии зрительных и аудитивных эталонов говорит следующий факт. Реакции на слово обезьяна содержат множество орфографических ошибок. На младших курсах корп. Б это слово незнакомо студентам, и мы имеем дело с вышеизложенными перцептивными трудностями. На старших же курсах студенты знают это слово, о чём свидетельствует дополнительный опрос. В реакциях на стимул некоторые студенты IV к. приводили перевод или указывали на сомнительность графической передачи слова. Это говорит о том, что они, услышав знакомое слово, или просто не слушали достаточно внимательно (в таком случае действовала установка на целостный знакомый образ), или были не в состоянии наспех и в затруднённых условиях различить звуки и передать их графически. Слуховой эталон у них сформирован, ведь они узнают звуковую форму и соотносят с ней правильное значение. Но зрительный образ недостаточно закреплён - и сразу проявляются ошибки и трудности в передаче звуков. Это ещё раз подтверждает мысль о том, что стабильные визуальные образы способны компенскровать ауди- 
тивные трудности. Поэтому, возможно, имеет смысл проверять сформированность собственно перцептивных эталонов изучаемого языка, базируюших на слуховых образах, на материале незнакомых слов (ср. также [Джаларидзе 1985:13]).

\section{3 Результаты дисперсионного анализа}

Общие результаты не дают возможности понять, насколько сформирован механизм восприятия на русском языке у ии. корп. Б по сравнению с группами корп. А. Такие выводы можно сделать лишь на базе данных днсперсионного анализа и восприятия градаций конкретных факторов.

Результаты дисперсионного анализа представлены в табл. 16. Как видно, в МО немцев корп. Б существенно большее количество факторов, чем у немцев корп. А (табл. 9).

Эо пронсходит в основном за счёт фонетических факторов, в частнссти - ДП согласных. Видимо, ии. корп. Б вслушиваются больше в предъцвляемые стимулы, так как для них речь носителя русского языка в целом менее привычна, чем для ии. корп. А. Возможно, здесь также сказывается разница в качестве используемой аппаратуры.

Набор существенных признаков и в корп. Б достаточно стабилен на всек курсах. Наиболее значимыми факторами являются "F суб", "F о6" и "часть речи". К ведущим признакам примыкают "количество квазиомонимов' и "длина в морфемах". Усиливается также роль фактора "консонантный коэффициент". Влияние фактора "длина в слогах" хоть и растёт по меге овладения языком, но тем не менее оно значительно ниже, чем в МО носителей русского или немецкого языков или ии. корп. А. На всех курса> этот признак опережается фактором "длина в морфемах". Это является важной особенностью восприятия ии. корп. Б.

.Три этом надо учесть особый характер морфем как частей слов: В силу своей значимости, целостности и повторяемости они являются как бы сутгештальтами. Как таковые, они способны компенсировать некоторые перцептивные трудности.

Зстаёт вопрос: Не усиливается ли опора на морфемы хотя бы отчасти потому, что пофонемный (послотовый) анализ представляет для ии. знцчительные трудности и поэтому отодвигается на задний план при первок удобном случае? Реакция типа посмотри(me) на стимул поcмотлеть говорит именно о том, что на основании приёма некоторых, правді, недостаточных, опорных элементов ии. прекратили анализ стимула $r$ включили вероятностный прогноз. 
Таблича 16. Показатели силь влияния $r^{2}$ и ранги $R$ факторов (корп. Б)

\begin{tabular}{|c|c|c|c|c|c|c|c|c|}
\hline \multirow[t]{3}{*}{ Фактор } & \multicolumn{8}{|c|}{ Курс } \\
\hline & \multicolumn{2}{|c|}{$\mathbf{I}$} & \multicolumn{2}{|c|}{ II } & \multicolumn{2}{|c|}{ III } & \multicolumn{2}{|c|}{ IV } \\
\hline & $r^{2}$ & $\mathbf{R}$ & $r^{2}$ & $\mathbf{R}$ & $r^{2}$ & $\mathbf{R}$ & $\mathbf{r}^{2}$ & $\mathbf{R}$ \\
\hline$F_{c y 6}$ & $\underline{0,135}$ & 1 & $\underline{0,224}$ & 1 & $\underline{0,225}$ & 1 & $\underline{0,187}$ & 1 \\
\hline$F_{06}$ & $\underline{0,088}$ & 3 & $\underline{0,098}$ & 3 & $\underline{0,091}$ & 2 & $\underline{0,046}$ & 3 \\
\hline Количество квазиомонимов & $\underline{0,021}$ & 4 & 0,011 & 11 & $\underline{0,022}$ & 5 & $\underline{0,015}$ & 6 \\
\hline Часть речи & $\underline{0,101}$ & 2 & $\underline{0,100}$ & 2 & $\underline{0,074}$ & 3 & $\underline{0,059}$ & 2 \\
\hline Длина в слогах & $\underline{0,009}$ & 11 & $\underline{0,005}$ & 9,5 & $\underline{0.011}$ & 7 & $\underline{0,010}$ & 8 \\
\hline Длина в морфемах & $\underline{0,012}$ & 8,5 & $\underline{0,015}$ & 4,5 & $\underline{0,023}$ & 4 & $\underline{0,017}$ & 5 \\
\hline $\begin{array}{l}\text { Количество слого-морфемных } \\
\text { стыков }\end{array}$ & $\underline{0,005}$ & 12 & 0.001 & 16 & $\underline{0,007}$ & 11 & 0.002 & 16 \\
\hline Ритмика $\mathrm{H}-\mathrm{C}-\mathrm{K}$ & $\underline{0.002}$ & 14.5 & 0.004 & 14 & 0.003 & 15 & $\underline{0,008}$ & 9 \\
\hline Консонантный козффициент & $\underline{0,013}$ & 7 & $\underline{0,010}$ & 6.5 & $\underline{0,015}$ & 6 & $\underline{0,035}$ & 4 \\
\hline Количество консонансов & $\underline{0,004}$ & 13 & 0,003 & 15 & $\underline{0,004}$ & 13 & $\underline{0,012}$ & 7 \\
\hline Ударная гласная & $\underline{0,012}$ & 8.5 & 0,006 & 12 & $\underline{0,009}$ & 8 & $\underline{0,005}$ & 11,5 \\
\hline Начальный звук & $\underline{0.002}$ & 14.5 & $\underline{0,005}$ & 9,5 & $\underline{0,006}$ & 12 & $\underline{0,002}$ & 15 \\
\hline ШІумность - сонорность & $\underline{0,011}$ & 10 & $\underline{0.007}$ & 8 & 0,008 & 14 & $\underline{0,007}$ & 10 \\
\hline Смычность - щелевость & 0,002 & 16 & 0,005 & 13 & 0.001 & 16 & $\underline{0,004}$ & 13 \\
\hline Звонкость - глухость & $\underline{0,018}$ & 5 & $\underline{0,010}$ & 6.5 & $\underline{0,008}$ & 9.5 & $\underline{0,005}$ & 11.5 \\
\hline Твёрдость - мягкость & $\underline{0,017}$ & 6 & 0,015 & 4,5 & $\underline{0,008}$ & 9.5 & $\underline{0,003}$ & 14 \\
\hline$\sum r^{2}$ & 0,452 & & 0,519 & & 0,515 & & 0,417 & \\
\hline$\sum r_{\text {syw }}^{2}$ & $\underline{0,450}$ & & $\underline{0,489}$ & & $\underline{0,503}$ & & $\underline{0,415}$ & \\
\hline
\end{tabular}

Вместе с тем, опора на морфемы предполагает определённые знания морфологического строя изучаемого языка. Видимо, на I к. они ешё недостаточны, и влияние фактора ещё невелико (ранг 8,5). Однако в дальнейшем усиливается значение этого признака.

Другие особенности МО ии. корп. Б проявляются в фонетических факторах. В отличие от данных корп. А опора на признак "ударная гласная фонема" не усиливается. Заметные сдвиги в значимости факторов 
наблюдаются на уровне ДП согласных: на I к. средняя от рангов равна 9,2 на II к. $-8,0$, а на III и IV к. - 12,2 и 12,1 соответственно. Такая динамика характерна только для корп. Б. На фоне данных о роли ДП в разных условиях приёма можно сделать вывод о том, что субъективная сложность восприятия русских слов уменьшается прежде всего после стажировки в языковой среде - в городах Москва и Минск.

Судя по всему, ии. корп. Б усиливают восприятие по частям: с одной стороны, это пофонемный (послоговый) анализ, с другой стороны, это поиск знакомых регулярных и осмысленных отрезков. При этом более высокий уровень обработки сигнала (морфемный) является ведущим. Как отмечает в этой связи К. Костер, иностранцы часто безуспешно используют более высокий уровень обработки стимулов. Он объясняет это недостаточным владением лексикой языка [Koster 1987:11]. Но тем не менее вышеизложенные факты показывают, что первичные трудности лежат на фонетическом уровне. Знание слов и морфем, т.е. гештальтов и субгештальтов, в какой-то степени компенсируют эти трудности.

\section{4 Результаты по ранговой корреляции}

Коэффициенты ранговой корреляции отражают тенденцию к сближению как с МO, определённом на родном языке ии., так и с МО носителей изучаемого языка (табл. 17).

Таблица 17. Коэффициенты корреляции корпуса Б

\begin{tabular}{|l|c|c|c|c|}
\hline \multirow{2}{*}{ Коэффициент корреляции } & \multicolumn{4}{|c|}{ Курс } \\
\cline { 2 - 5 } & I & II & III & IV \\
\hline С немецким языком & 0,25 & 0.05 & 0,49 & 0,42 \\
С русским языком & 0.22 & -0.07 & 0.44 & 0.40 \\
\hline
\end{tabular}

Как видно, козффициенты корреляции с родным и изучаемым языками почти совпадают. Так же, как в корп. А, наблюдается упорядочивание $\mathrm{MO}$, сопровождающее процесс усвоения языка. Оно является индикатором возросшей языковой компетенции. Но если при обучении в среде носителей языка механизм восприятия и общий уровень владения языком демонстрируют явную связь, то в корп. Б картина сложнее. При обучении, которое не предполагает постоянного контакта с естественной языковой средой, МО характеризует в первую очередь становление перцептивных навыков как таковых. Поэтому неудивительно, что заметный прогресс в формировании МО регистрируется после стажировки в России и Белоруссии. Отсутствие корреляции со сформированными МО на 
II к. связываются нами прежде всего с тем, что на II к. уже не проводится занятий по фонетике. Правда, динамику на I и II к. следовало бы проверить на одной и той же группе ии.; однако в рамках данной работы это было невозможно. Поскольку II к. даёт своеобразные результаты по ряду параметров, можно также предположить, что на этом этапе владения языком подготавливается некоторая перестройка механизма восприятия. Аналогичные наблюдения были сделаны на III к. обучения французскому языку русских [Щербакова 1984].

Аргументом в пользу предположения о том, что в корп. Б перцептивные навыки образуют более автономную область владения языком, чем в корп. А, является тот факт, что ии. IV к. не обнаруживают дальнейшего роста корреляции с МО носителей изучаемого языка. Думается, что это обусловлено минимальной речевой практикой на русском языке после стажировки. Но тогда надо допустить, что МО сформирован непрочно и легко поддаётся воздействию родного или другого, более актуального изучаемого языка. Однако, это лишь гипотеза. Уточняющую информацию можно получить только в аналогичном эксперименте, проведённом через больший промежуток времени после стажировки.

Так же, как в корп. А, ряд отклонений от сформированных МО характеризует специфику восприятия на втором, изучаемом языке. Так, по сравнению с носителями обоих языков ии. корп. Б усиливают опору на факторы " $F_{c y 6}$ и " $F_{o g}$ ", на частеречную принадлежность слов и на морфемы как значимые элементы слов. Ии. корп. Б меньше, чем носители обоих языков, в состоянии опираться на "длину в слогах". Значительно меньшую роль, чем у русских, играет также фактор "ударная гласная фонема". В корп. А влияние последних двух факторов больше.

О сближении именно с механизмом восприятия русского языка говорит опора на "количество квазиомонимов", которая наблюдается на всех курсах, кроме II к. По мере овладения языком усиливается влияние признака "консонантная нагрузка", что также означает приближение к МО русских.

Уже на I к. корп. Б признак "твёрдость - мягкость", достаточно важный для МО носителей языка, занимает высокий ранг. Это говорит о том, что в обработке стимулов учитывается эта специфика изучаемого языка. Было бы интересно проследить, насколько это является результатом обучения языку. (Напомним, что все ии. учили русский язык в школе.) В этих целях необходимо было бы проводить слуховой эксперимент в самом начале обучения языку. Заметим, что повышение ранга фактора "количество консонансов" не отражает истинного сближения с данными носителей русского языка (см. ниже, п. 5.5.5). 


\section{5 Анализ факторов}

\subsection{1 Объективная частота $F_{\text {о6, }}$ субъективная частота $F_{\text {cy6 }}$}

Факторы "F о6" и "F суб" относятся в MO всех групп ии. к наиболее значимым признакам (табл. 16). Ии. корп. Б опираются на частотные характеристики слов ещё больше, чем ии. корп. А. Об этом свидетельствуют высокие значения $\mathrm{r}^{2}$. Этот факт позволяет предположить, что условия приёма для ии. корп. Б субъективно труднее, чем для учащихся корп. А. В этой связи следует обратить внимание на динамику $\mathrm{r}^{2}$ факторов в $\mathrm{MO}$ ии. корп. Б. Тенденция такова: начиная со II к., по мере овладения языком, уменьшается абсолютное значение " $F_{06}$ " и " $F_{c y 6}$ ". Возможно, относительно низкое значение $\mathrm{r}^{2}$ на I к. является следствием усиления позлементной стратегии восприятия. Можно также допустить, что сама способность к опоре на частоту слов развита слабее в силу ещё недостаточного речевого опыта.

При сопоставлении значений $\mathrm{r}^{2}$ факторов в МО носителей немецкого и русского языков, а также ии. корп. А и Б возникает следующая гипотеза: чем более привычна постоянная речевая практика, чем богаче речевой опыт, тем ниже абсолютное значение признаков " $F_{06}$ " и " $F_{c y 6}$ ".

Так же, как в корп. A, $r^{2}$ признака "F 06 " значительно уступают данным по "F суб". Это ещё раз подтверждает положение о том, что оценки по " $F_{\text {суб }}$ " коррелируют с опознанием лучше, чем данные по " $F_{06}$ ".

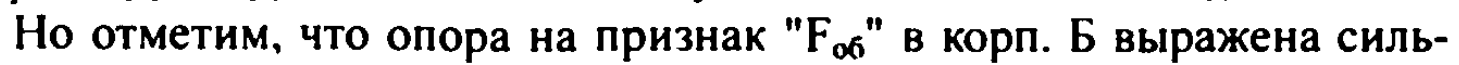
нее, чем в корп. А. За исключением III к., когда студенты находятся шесть или десять месяцев в Росии или Белоруссии, возможности живого общения на иностранном языке для ии. корп. Б весьма ограничены. Поэтому речевой опыт учащихся формируется в большей степени под влиянием письменных текстов, что сказывается в значении признака "Fo6". Однако по мере овладения языком уменьшается относительное влияние

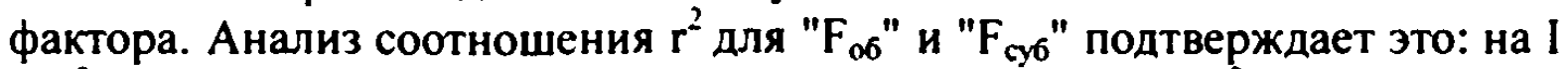
к. $\mathrm{r}^{2}\left(\mathrm{~F}_{\mathrm{o \sigma}}\right)$ составляет $65 \%$ соответствующего показателя $\mathrm{r}^{2}\left(\mathrm{~F}_{\text {суб }}\right)$, на II к. $44 \%$, на III К. - $40 \%$, а на IV к. - $24 \%$. Примечательно, что именно после десятимесячной стажировки в языковой среде влияние признака " $F_{06}$ " уменьшается в два раза и достигает уровня I к. корп. А. Более короткая стажировка не приводит к таким значительным изменениям В структуре внутреннего лексикона.

Этот вывод подтверждается при рассмотрении градаций фактора " $F_{06}$ " (рис. 45). Результаты восприятия очень близки для II и III к., хотя их разделяет полгода стажировки. В целом корреляция между признаком " $F_{06}$ " и опознанием стимулов выражена более ярко, чем в корп. А. Некоторое ухудшение опознания высокочастотных слов на IV к. объясняется 
конкуренцией факторов: возможно, в данном случае большую роль играет длина слов.

Pис. 45. Восприятие слов в зависимости от признака " $F_{\text {о6 }}$ (Kopn. Б)

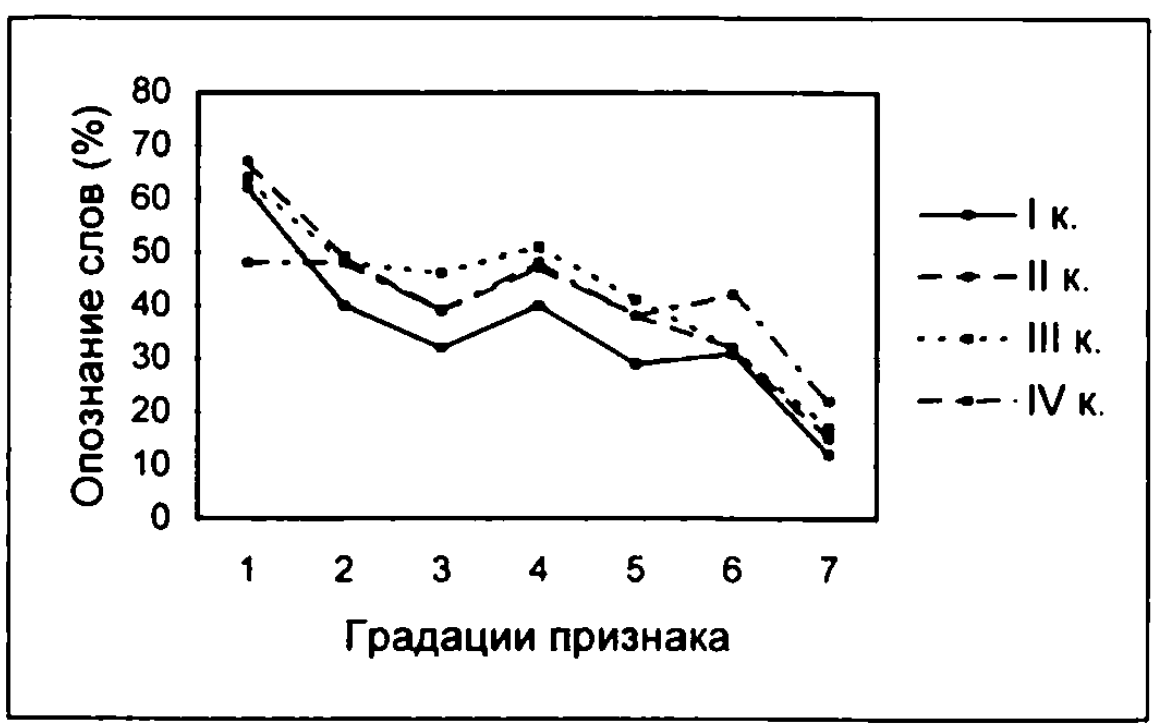

Рис. 46. Восприятие слов в зависимости от признака " $F_{\text {суб" }}$ (корn. Б)

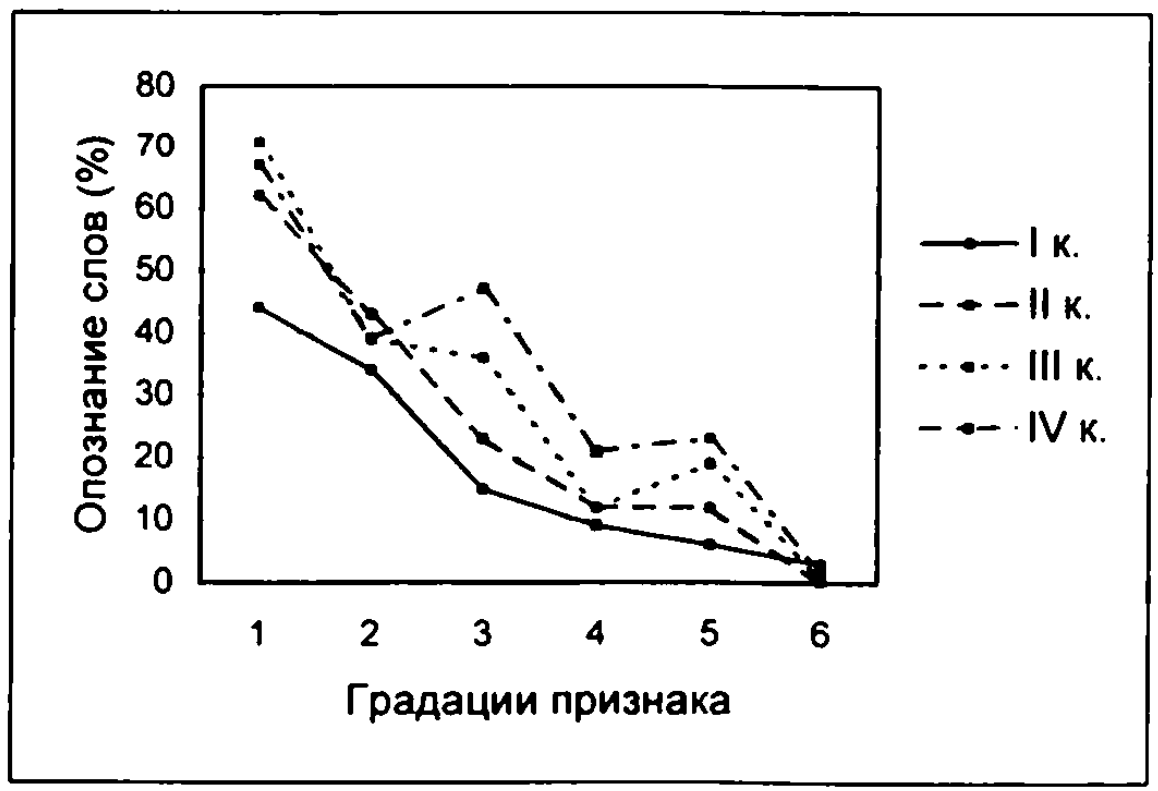

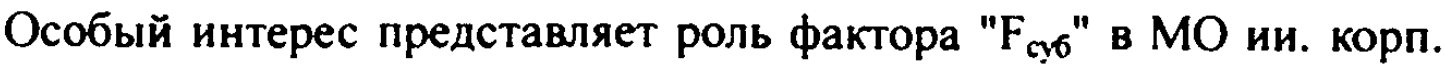
Б. Так же, как в корп. А, на всех курсах наблюдается чёткая корреляция между частотными оценками, которые были даны носителями русского языка, и результатами восприятия (рис. 46). Это примечательно потому, что по крайней мере до III к. речевой опыт ии. базируется в основном на 
русской речи преподавателей-немцев и на текстах, с которыми учащиеся работают.

Поскольку корреляция с частотными оценками носителей русского языка наблюдается независимо от условий обучения, возникла следующая гипотеза: зависимость, наблюдаемая в обоих корпусах, вызвана тем, что употребительность соответствующих слов примерно совпадает в немецком и русском языках. Для проверки этого предположения русская программа стимулов была переведена на немецкий язык. По методике Р.М. Фрумкиной и А.П. Василевича [Фрумкина, Василевич 1971] был составлен частотный словарь. Сравнение оценок (т.е. $\mathrm{Me}_{\mathrm{p}}-\mathrm{Me}_{\boldsymbol{H}}$ ) для существительных выявило, что они в среднем расходятся на 0,76 , т.е. меньше чем на один оценочный интервал. Таким образом, гипотеза подтвердилась: восприятие коррелирует с практически одинаковыми в обоих языках частотными оценками. Видимо, сходство оценок обусловлено в первую очередь экстралингвистически: культурный фон в обеих странах достаточно близок и это, конечно, сказывается на употребительности как денотатов, так и соответствующих языковых обозначений. Но тогда возникает методический вопрос о том, что, собственно, оценивают ии. встречаемость денотатов или же слов. В целях выяснения этого вопроса следовало бы провести сопоставительные исследования частотных оценок для таких слов, употребительность и сочетаемость которых в большей мере определяется системой конкретного языка. Было бы также интересно посмотреть, как соотносятся оценки русских и немцев на всём материале. Кроме того, можно было бы проследить, какие частотные оценки для русских слов складываются у немцев в процессе обучения и как они коррелируют с восприятием.

При анализе конкретных результатов восприятия особое внимание заслуживает улучшение опознания слов средних и низких частот (градации 3 - 5). Пополнение менее частотного пласта лексики проявляется особо ярко у тех студентов, которые почти год учились в языковой среде (рис. 47). На фоне данных носителей русского и немецкого языков можно считать, что восприятие слов именно средних и низких частот позволяет сделать выводы об уровне владения лексикой языка. 
Рис. 47. Соотночение среднего опознания слов по градачияи фактора "F $F_{\text {суб }}$ на I к. и IV к. (корп. Б)

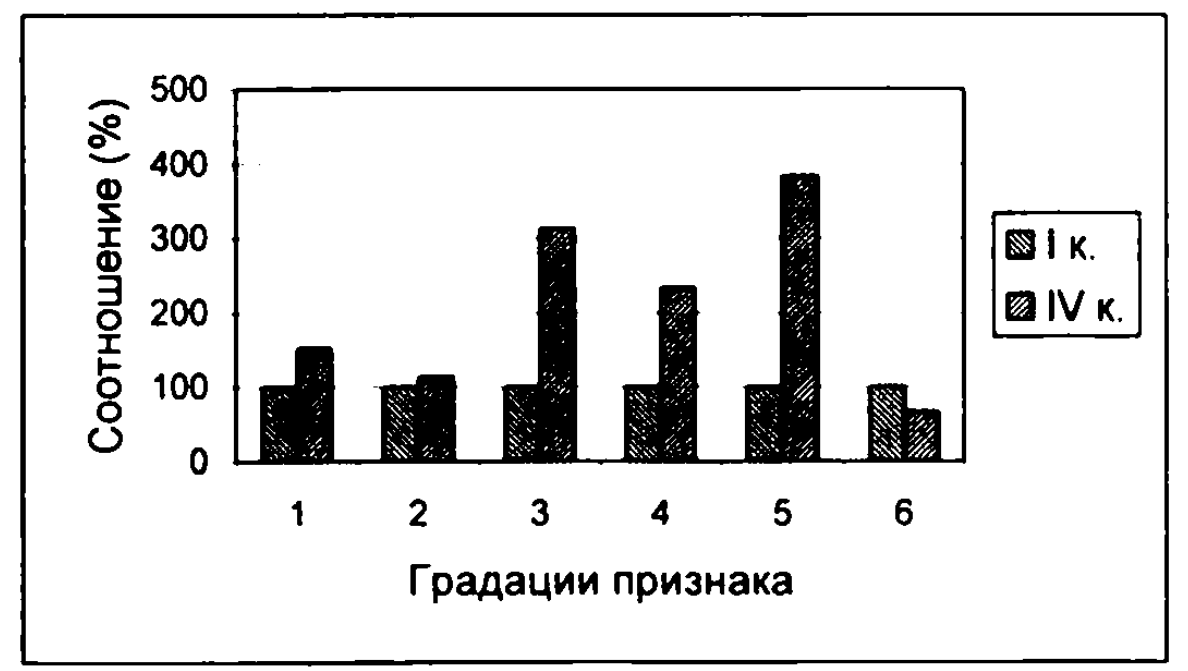

\subsection{2 Количество квазиомонимов}

Фактор "количество квазиомонимов" относится в корп. Б к ведущим лингвистическим признакам (табл. 16). Исключение составляет II к. Но сравнение с корп. А выявляет, что значение $r^{2}$ там выше, т.е. фактор действует сильнее. Кроме того, на старших курсах корп. Б не наблюдается роста влияния признака. В то же время влияние фактора на I к. корп. Б выше, чем на I к. корп. А. Возможно, сказывается актуальный речевой опыт: многие упражнения корректировочного фонетического курса строятся на чередовании квазиомонимов [Wenk u.a. 1985].

При анализе конкретных данных оказывается, что результаты восприятия колеблются в корп. Б больше, чем в корп. А. Тем не менее проявляется общая тенденция, которая заключается в обратной зависимости между количеством квазиомонимов и опознанием слов. Показательно, что она выступает на IV к. ярче, чем на предыдуших курсах (рис. 48). Очевидно, по мере накопления речевого опыта усиливается автономность этого признака.

Поскольку фактор не балансировался, дополнительно проведён анализ восприятия на выверенном по признаку "длина в слогах" материале. Расчёт для трёхсложных слов показывает, что на IV к. слова без квазиомонимов воспринимаются лучше $(87 \%)$, чем слова с одним/двумя $(45 \%)$ или тремя/четырьмя (27\%) квазиомонимами. На I же к. эта связь проявляется менее чётко: мы имеем соответственно $43 \%, 51 \%$, и $31 \%$ в среднем правильно опознанных слов.

На материале только односложных слов выходит обратная тенденция: слова с девятью и более квазиомонимами воспринимаются лучше двух предыдущих градаций. Между прочим, это обнаруживается также в 
корп. А. С одной стороны, на данный результат влияет высокая частота тех односложных слов, которые попадали в интервал (8 - 16]. Поэтому ещё раз подчеркнём, что тестирование уровня владения лексикой языка на базе квазиомонимии должно пронсходить на сбалансированном по частоте материале. С другой стороны, результат объясняется несформированностью большого класса квазиомонимов в сознании учащихся, что априори повышает вероятность опознания слов.

Рис. 48. Зависимость восприятия слов от количества квазиомонимов (корп. Б)

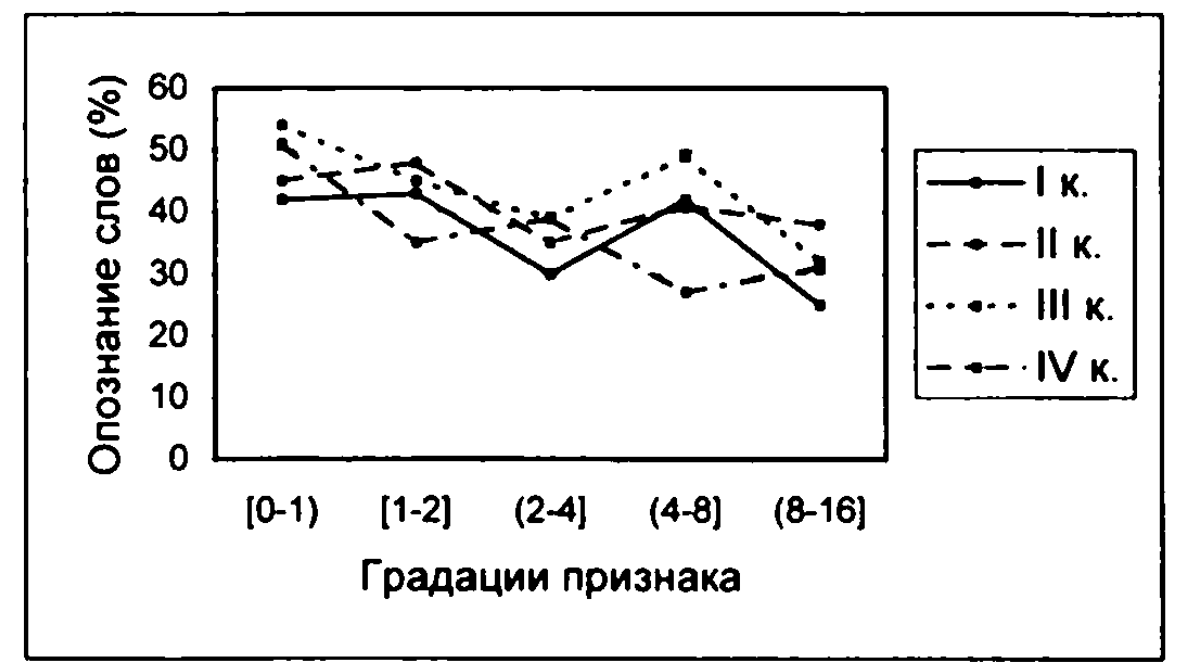

\subsection{3 Длина в слогах}

В механизме опоры носителей русского, немецкого и английского языков фактор "длина в слогах" относится к нанболее важным. Намного менее значим он при восприятии русских слов у ии. корп. Б; вместе с тем, его вес в иерархии признаков растёт (табл. 16). На фоне данных, полученных в корп. А, можно сделать вывод о том, что параллельно с уровнем владения иностранным языком растёт опора на длину стимулов. Это подтверждается при восприятии английских слов русскими, в разной степени владеющими английским языком [Чугаева 1989].

Малая значимость фактора на низком уровне владения языком, равно как при восприятии незнакомых слов (см. ниже), объясняется тем, что в этих случаях слово воспринимается скорее поэлементно (послогово). Интегрирующая функция слогов, создающая контур слова, ещё не может быть использована достаточно успешно. Для аудиторов слова состоят как бы из равноценных блоков, которые прнсоединяются друг к 
другу по мере опознания. ${ }^{50}$ Поэтому ещё не наблюдается чёткой дифференциации восприятия в зависимости от длины стимулов, которая, видимо, предполагает бо́льшую опору на целостность стимула.

Это подтверждает наше предположение о том, что в зависимости от тяжести условий приёма признак "длина в слогах" может действовать двояко - как поэлементный и как целостный параметр. В этой связи следует указать на то, что в целом вес фактора в корп. Б значительно ниже. чем в корп. А (табл. 9, 16). Таким образом, по данному параметру ии. корп. Б отстают от носителей языка больше, чем ии. корп. А.

Это обнаруживается и при анализе по градациям (рис. 49). В отличие от восприятия ии. корп. А яркая дифференциация результатов восприятия в зависимости от длины не проявляется. Но главная разница на уровне градаций состоит в том, что ии. корп. Б лучше всего опознают не четырёхсложные слова, а трёхсложные.

\section{Рис. 49. Восприятие слов в зависимости от признака}

"длина в слогах" (корп. Б)

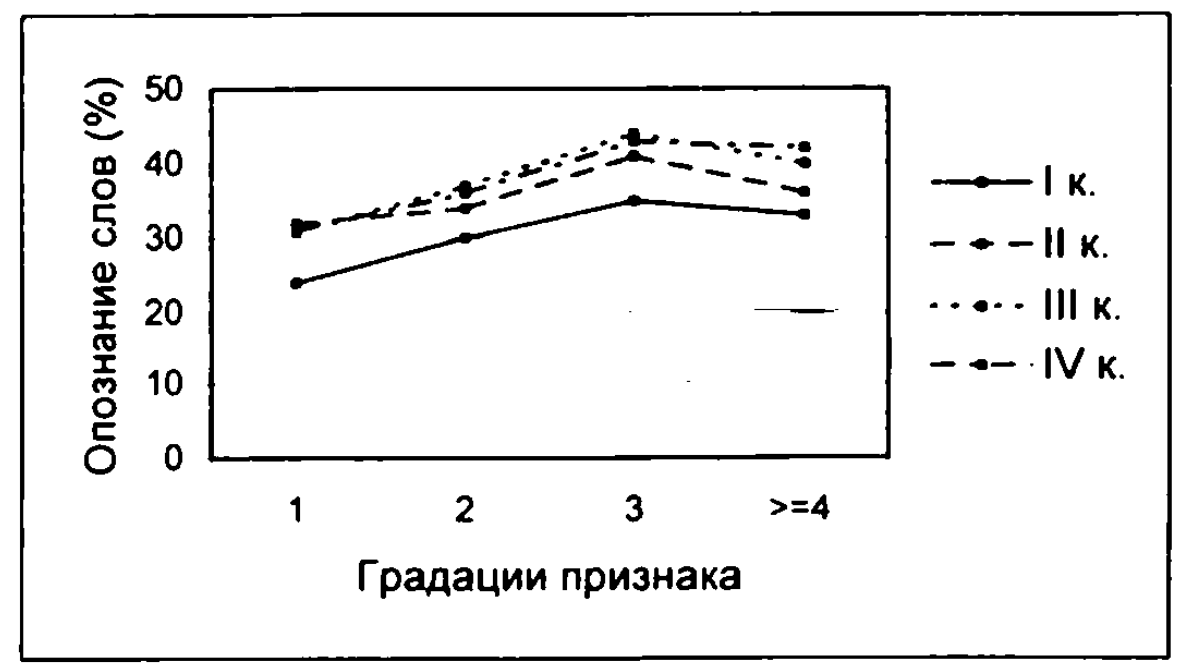

Эти трудности связываются с тем, что на I к. $50 \%$ слов из четырёх и более слогов незнакомы студентам. На IV к. их лишь $20 \%$. Значит нет в памяти ии. эталона, который позволял бы на основе нескольких опорных элементов идентифицировать стимул. Следует также учесть, что слова этой градации содержат как минимум два сильноредуцированных звука, что для немцев является перцептивно сложной ситуацией. Кроме того известно, что мощность оперативной памяти зависит от уровня владения языком - чем он ниже, тем меньше единиц удаётся удержать в

50 Аналогичный механизм был обнаружен при пословном восприятии иноязычного текста на относктельно низком уровне владения языком [Копыленко 1967; Макарова. Туркенбаев 1967: Чугаева 1989]. 
оперативной памяти. Думается, что это связано прежде всего с величи: ной тех блоков, в которых возможна обработка поступающей инфор мации. Логично предположить, что перегрузка оперативной памяти проявляется скорее в том случае, когда ии. вынужден к поэлементном) анализу стимулов [Zawadzka 1983:17]. Возможно, в данном случае словк из четырёх и более слогов образуют некоторый критический предел дль работы оперативной памяти.

\subsection{4 Ритмическая структура}

Признак "ритмическая структура (а)", т.е. "в линеечку", обнаруживаеา сходные с корп. А тенденции (рис. 50 а, 6 , в). Они заключаются в следу. ющем:

1. По отношению к двухсложным словам наблюдается положи. тельный перенос из родного языка: хореические структуры воспри. нимаются лучше ямбических. Подтверждается мысль о том, что ранеє усвоенные языковые структуры более помехоустойчивы не только Е родном, но и в изучаемом русском языке.

2. Восприятие трёх- и четырёхсложных слов улучшается по мерє передвижения ударения к концу слов. Ярче, чем в корп. А, эта тенденция проявляется в корп. Б. Наиболее благоприятными для восприятия немца. ми оказываются те структуры, которые не обладают заударными редуци. рованными.

Рис. 50 а, б, в. Восприятие слов в зависиности от ритиической структуры (корп. Б)

Рис. 50 а. Односложные и двухложные слова

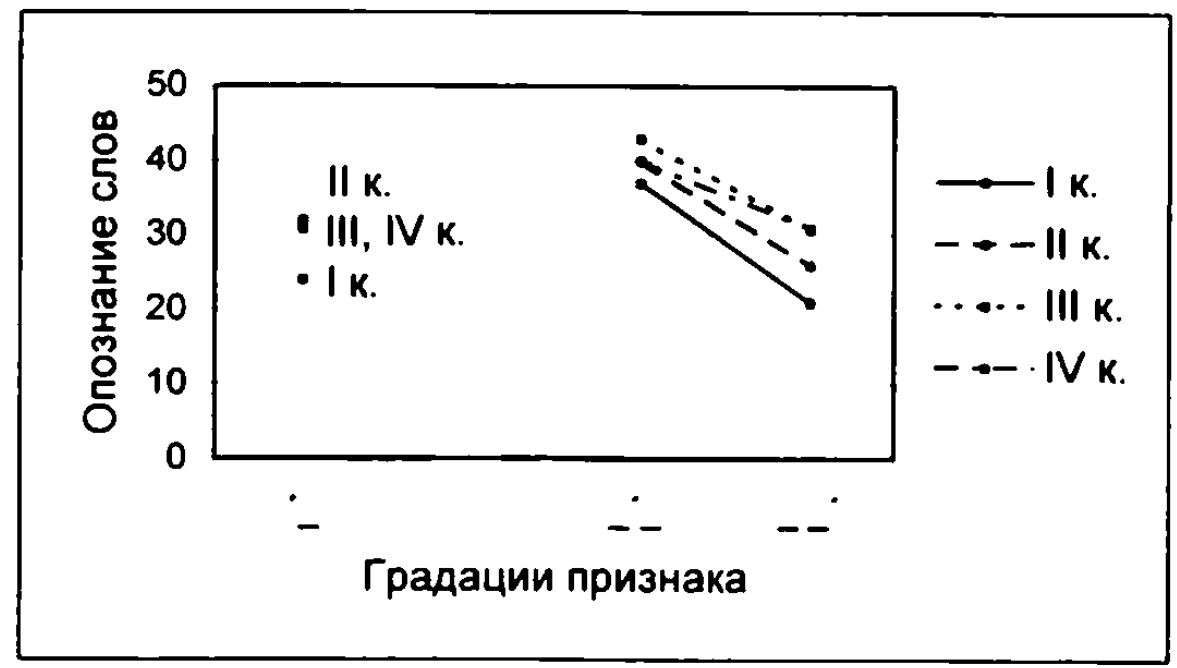


Рис. 50 6. Трехсложные слова

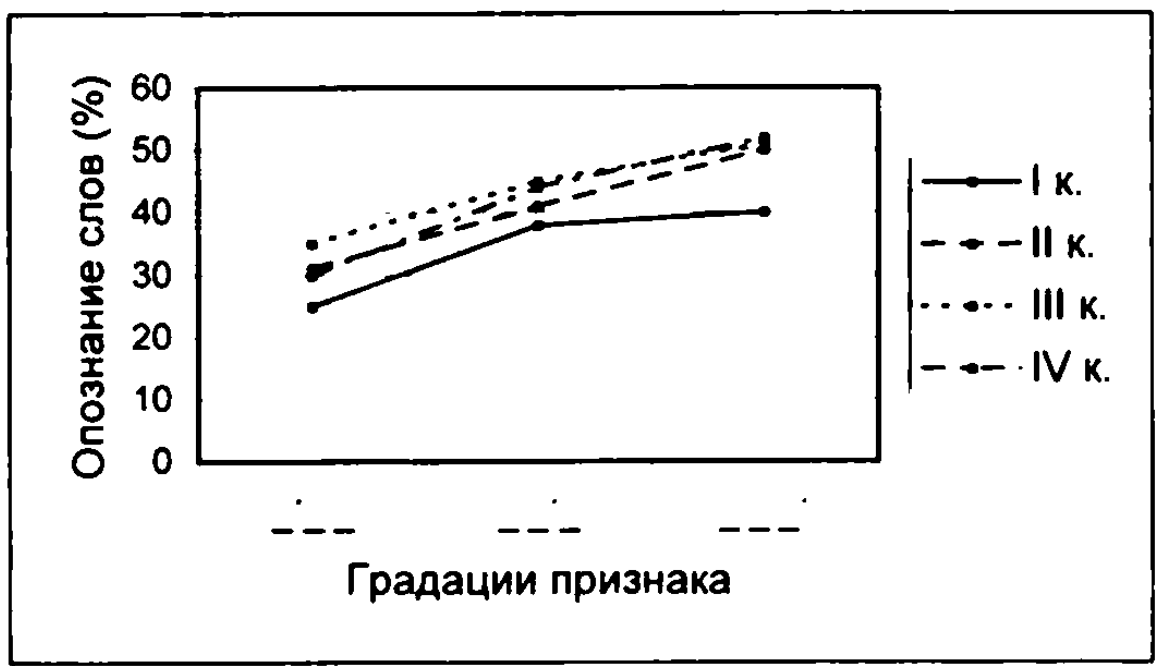

Рис. 50 в. Четырех- и более сложные слова

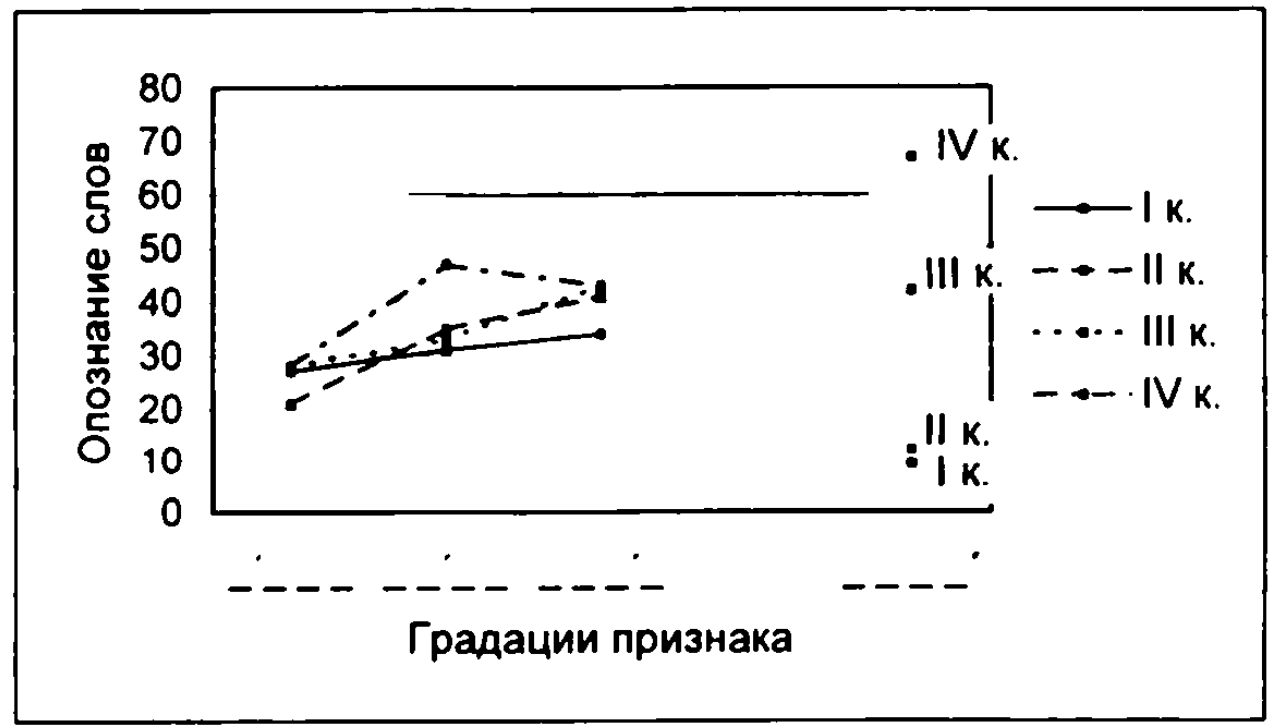

Заметная разница между обоими корп. ии. наблюдается по тому, как ии. справляются с перцептивно трудными структурами. Таковыми являются слова с двумя заударными слогами. ${ }^{51}$ С тудентам корп. Б, обладающим меньшим речевым опытом, не удаётся существенно улучшить опознание слов данной структуры. При восприятии таких слов опорные элементы передвигаются в область согласных. Но как показал эксперимент по слуховому восприятию слов без шума, восприятие согласных представляет большие трудности даже после специальной фонетической

51 Напомним, что слова с тремя заударными слогами нами не рассматриваются (см. 5.5.4). 
тренировки на I к. ${ }^{52}$ Кроме того, согласные маскируются белым шумом больше, чем гласные.

Перейдём к описанию обобщённого параметра "ритмика $\mathrm{H}-\mathrm{C}-\mathrm{K}$ ". Как и в других исследованных выборках, этот признак не влияет существенным образом на восприятие (табл. 16).

Из рис. 51 видно, что на I и II к. слова с ударением в середине воспринимаются немного лучше остальных градаций. Возможно, на этих курсах сказывается интерференция родного языка, в котором слова с серединным ударением воспринимаются несколько лучше других. Напомним, что на первых двух курсах обучение проводится в немецком языковом окружении.

Ha III и IV к. мы отмечаем выравнивание восприятия слов с ударением в середине и конце слова. Это соответствует той тенденции, которая наблюдается в корп. А. Но поскольку восприятие слов с начальным ударением не улучшается существенным образом, мы не можем говорить о сближении с данными носителей русского языка.

Pис. 51. Восприятие слов в зависиности от места ударения (корn. Б)

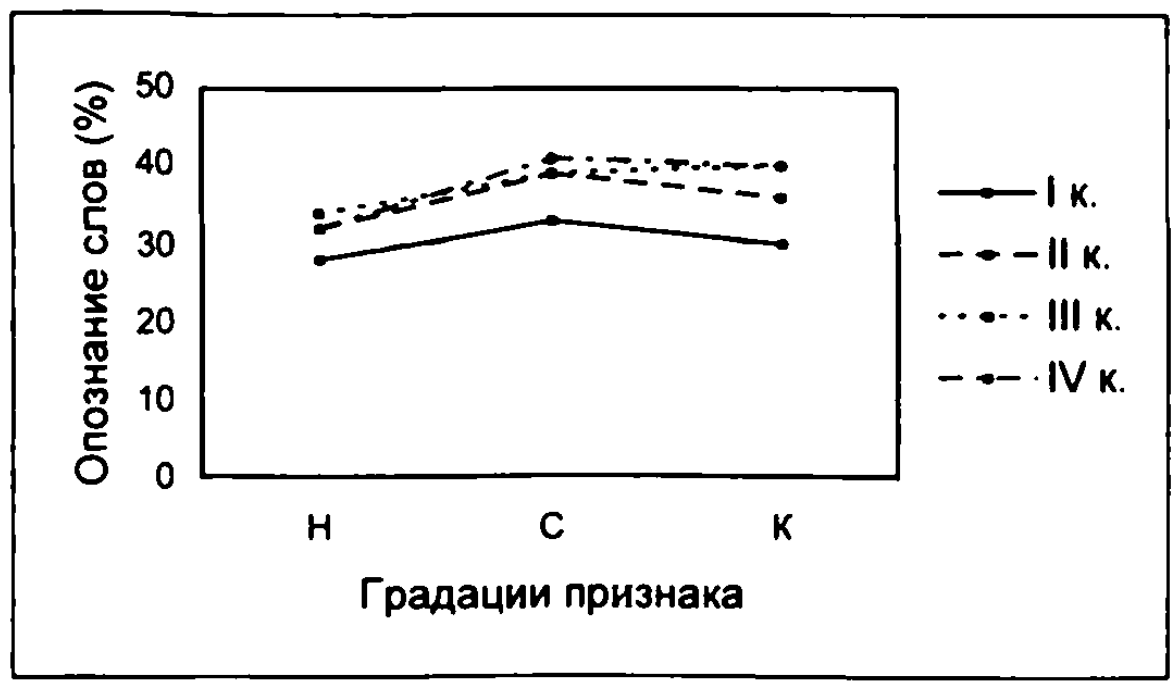

\subsection{5 Факторы морфемного уровня}

Обратимся сначала к фактору "часть речи". Так же, как в корп. А, он принадлежит к наиболее значимым признакам (табл. 16). Следует отметить, что общая тенденция поведения этого фактора одинакова в корп. А и Б. Это можно трактовать следующим образом: во-первых, частеречная принадлежность слов имеет большое значение для восприятия русского

\footnotetext{
52 Таким образом. фонетический курс на I к. является недостаточным для формирования или. скорее всего. коррекции аудитивных навыков на русском языке.
} 
языка как иностранного, нежели как родного; во-вторых, по мере овладения языком ослабевает опора на этот признак, о чём свидетельствует уменьшение $\mathrm{r}^{2}$. Значит ослабевает опора на определённую часть слова.

Из рис. 52 а видно, что, начиная с I к., наблюдается чёткая дифференциация в опознании отдельных частей речи. Как и в корп. А, лучше всего воспринимаются те слова, которые морфологически маркированы наиболее однозначно, т.е. числительные и прилагательные. В корп. Б к ним примыкают глаголы. Таким образом, более чёткая разница между опознанием существительных и глаголов отличает ии. корп. Б от ии. корп. A.

Отчётливая тенденция к улучшению восприятия при переходе на более высокий уровень владения языком наблюдается только для существительных и местоимений. Это те части речи, которые воспринимаются хуже всего. Улучшение восприятия существительных наблюдается и в корп. А. Уровень опознания местоимений там, однако, не увеличивается В силу краткости. В корп. Б сильнее действует вероятностный механизм, что и приводит к улучшению восприятия высокочастотных местоимений.

Рис. 52 а. Восприятие слов в зависимости от признака"часть речи" (корп. Б)

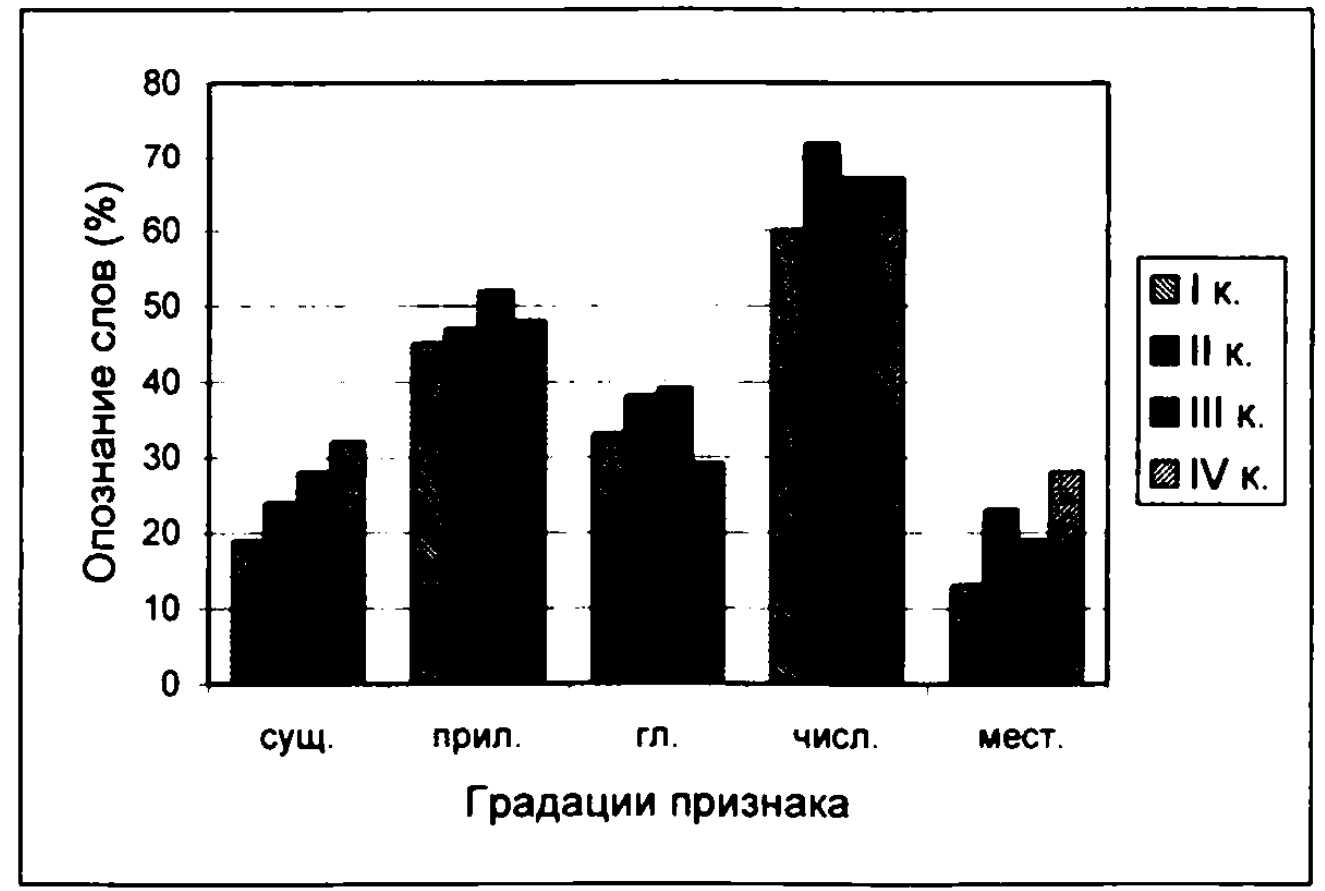

Анализ опознания частеречной принадлежности в заменах выявляет достаточно сходное восприятие признаков "числительность", "прилагательность", "глагольность" на всех курсах (рис. 52 б). Это ещё раз подтверждает мысль о том, что учащиеся оперируют морфологической мар- 
кированностью этих частей речи, начиная с I к. Тем более удивительно, что на IV к. ухудшается опознание как самих глаголов, так и "глагольности". Усиливается замена глаголов существительными, представляющими наиболее вероятную в данной ситуации часть речи. Этому способствует и фонетическая недодифференциация конечных [t'] и [t:s], которые заменяются в ответах на письме на " $r$ " (/t) и "u" (/ts/). Возможно, здесь уже проявляется некоторое ухудшение перцептивных навыков, обусловленное недостаточной речевой практикой.

Рис. 52 6. Опознание частеречной принадлежсности стимулов (корn. Б)

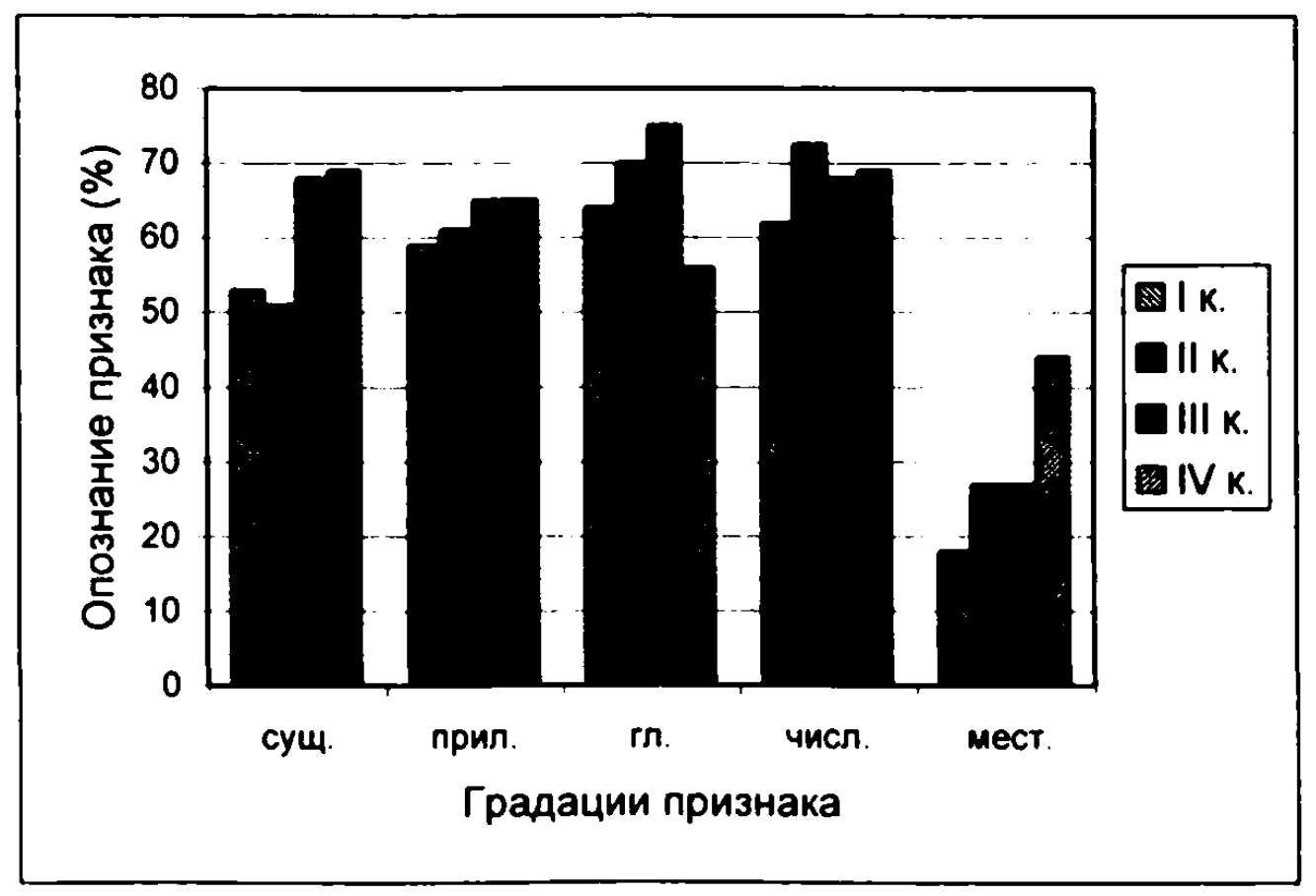

Значительным улучшением характеризуется восприятие "существительности" и "местоимённости" (рис. 52 6). С одной стороны, это связывается с вероятностным прогнозированием. С другой стороны, здесь сказывается накопленный речевой опыт, расширенная лексическая база. Примечательно, что восприятие "существительности" значительно улучшается именно после стажировки в языковой среде. На III и IV к. "существительность" воспринимается так же хорошо, как "прилагательность" или "числительность". Это связано ещё с тем, что морфология и словообразование освоены лучше, чем на I и II к. (Во время стажировки учащиеся специально занимались вопросами словообразования.)

При анализе "чистых замен" повторяется картина, ранее полученная в корп. А. Общая для всех курсов последовательность такова:

$$
C-\Gamma-\Pi-M-\Psi \text {. }
$$


Было бы интересно посмотреть, какова разница их ранжировки в других языках.

Посмотрим теперь, насколько ии. корп. Б опираются не просто на определённые морфемы, а на количество морфем в слове. Особенность этого признака в МО ии. корп. Б состоит в том, что "длина в морфемах" занимает более высокие ранги, чем "длина в слогах" (табл. 16). Исключение составляет I к., когда знание морфологии изучаемого языка ещё не достаточно.

Доминантность морфем над слогами отличает МО ии. корп. Б от МО носителей русского и немецкого языков. Очевидно, усиленная опора на морфемы характерна для субъективно более сложных условий приёма (см. п. 3.3.5, 4.3.5.). Показательно, что только на V к. включённого обучения появляется то же соотношение факторов, что и у носителей русского и немецкого языков.

Сам факт усиленной опоры на морфемы при восприятии должен учитываться в учебной практике. Необходимо подкрепить стратегию аудиторов соответствующими знаниями из области морфологии и словообразования.

Рис. 53. Зависимость опознания слов от количества морфем (Kopn. Б)

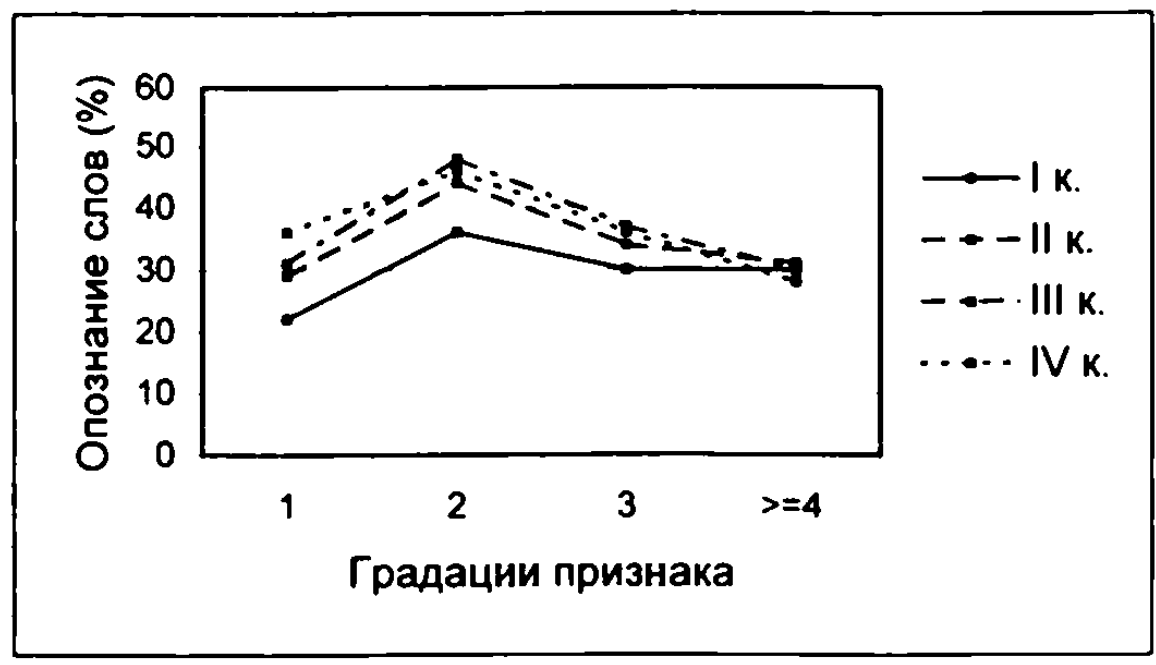

Анализ градаций факторов выявляет сходную для ии. обонх корпусов картину (рис. 53): успешнее всего опознаются двухморфемные слова. Они относятся к самым частотным структурам русского языка [Иванов, Новиков 1985:86]. Перцептивно они, видимо, достаточно прозрачны. Это подтверждает дополнительный анализ: односложные слова, типа стать, спать, содержашие служебную морфему, опознаются лучше слов корней. Обнаруживается то же влияние внутрисловесного кон- 
текста, которое мы нашли для ии. корп. А: двухморфемные слова с приставкой воспринимаются хуже слов с посткорневым аффиксом.

Так же, как в корп. А, был проведён дополнительный расчёт для двух - и трёхсложных слов с одинаковой $\mathrm{F}_{\text {об. }}$ В обоих корпусах бо́льшая морфемная структурированность способствует лучшему опознанию слов.

Основное отличие от восприятия градаций ии. корп. А видится в том, что ии. корп. Б не улучшают опознания четырёхморфемных слов. Это согласуется с данными, полученными по фактору "длина в слогах".

Влияние признака "количество слогоморфемных стыков", описывающего структурную прозрачность слов, в МО ии. корп. Б невелико (табл. 16). Общая для всех курсов тенденция совпадает с данными I и III к. корп. А: пик опознания отмечается для слов с одним совпадающим стыком, а слова с двумя и более совпадающими слого-морфемными границами воспринимаются примерно так же, как слова без стыков (рис. 54). Таким образом, ии. корп. Б вплоть до IV к. не в состоянии использовать структурную информацию, содержащуюся в слогоморфемных стыках, так же успешно, как в родном языке. Прямая зависимость между градациями данного фактора и результатами восприятия наблюдается только на V к. включённого обучения. Поэтому предполагается, что действие признака связано с уровнем владения языком и, в частности, со знанием его морфологических особенностей. Ознакомлению с ними следует уделять больше внимания.

Рис. 54. Восприятие слов в зависимости от количества слогоморфемных стыков (корп. Б)

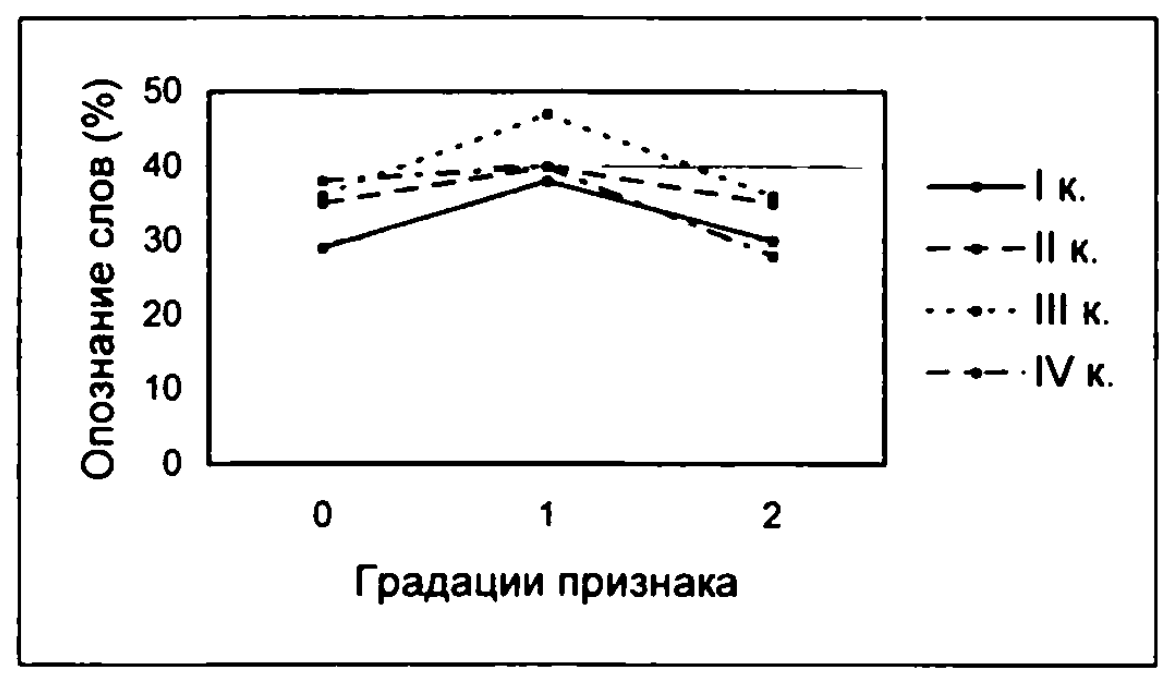

\subsection{6 Факторы фонемного уровня}

Фактор "ударная гласная фонема" оказывает на восприятие русских слов корп. Б меньше влияния, чем это наблюается у носителей русского и не- 
мецкого языков (табл. 16). Вес признака наиболее высок на I к., т.е. в период прохождения фонетического курса, и на III к., непосредственно после возвращения со стажировки в Москве. Подтверждается вывод о том, что восприятие слов иностранными учащимися определяется не столько фонемной принадлежностью ударного гласного, сколько другими, более сильными факторами.

Результаты восприятия по данному признаку представлены на рис. 55 a. Коэффициент корреляции с тем ранговым порядком, который был получен для носителей русского языка при анализе восприятия слов по ударному гласному, растёт от $\rho=0,36$ на I к. до $\rho=0,66$ на IV к. Отсутствие связи наблюдается на II к. $(\rho=-0,04)$. Таким образом, на старших курсах (как в корп. А, так и Б) усиливается связь между интенсивностью и частотностью русских гласных и опознанием стимулов.

Рис. 55 а. Восприятие слов в зависимости от ударной гласной фонемы (кopn. Б)

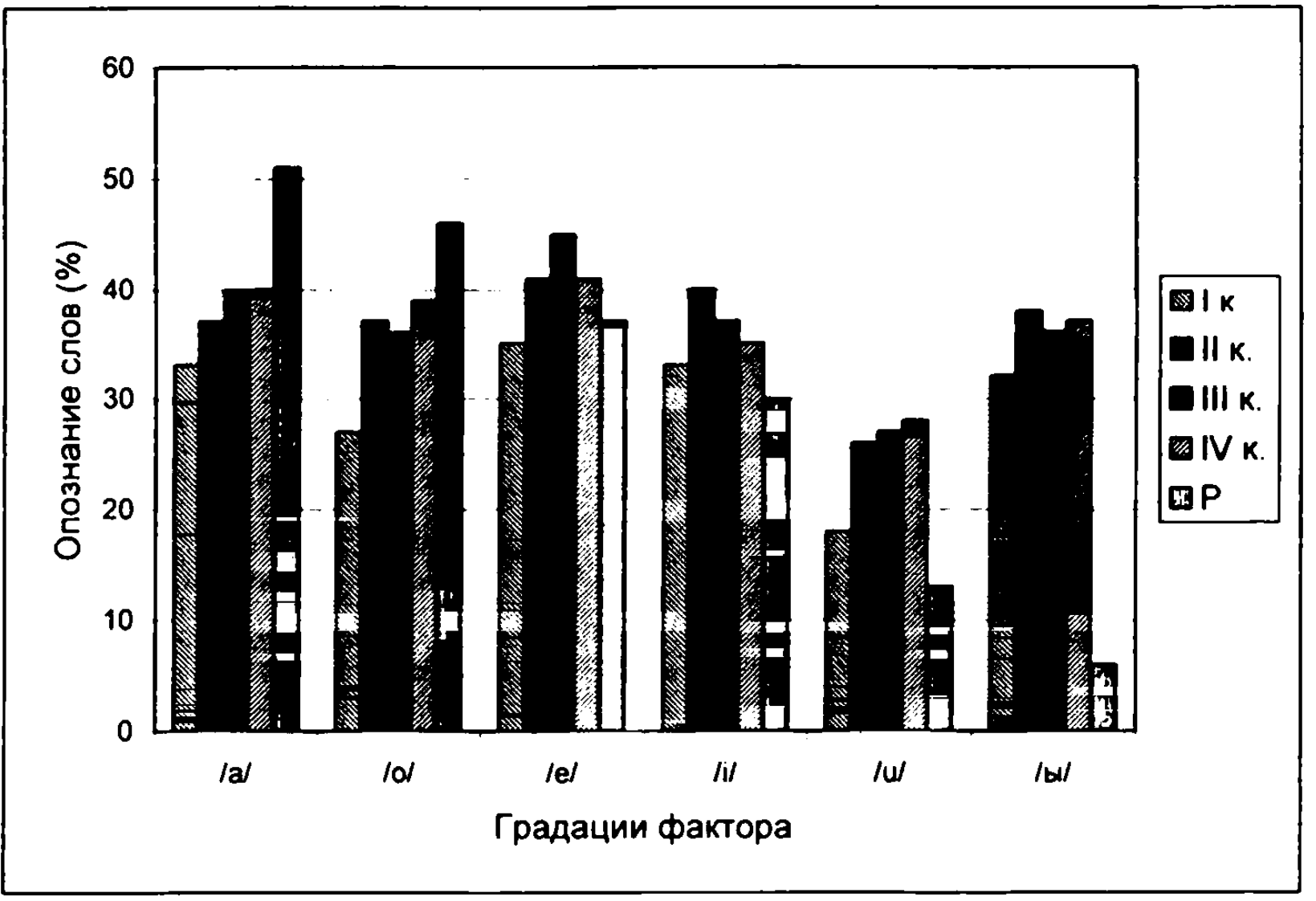

По восприятию самих гласных выстраивается следующая нисходяшая последовательность (ср. рис. 55 б):
I K.:
lo/ $-/ \mathrm{i} /-/ \mathrm{a} /-\mathrm{e} /-/ \mathrm{w}-/ \mathrm{y} /$;
II к.:
$/ 0 /-|\mathrm{i} /-| \mathrm{a} /-|\mathrm{e} /-| \mathrm{y} /-\mid \mathrm{w}$; 
III к.: $\quad / \mathrm{o} /-/ \mathrm{a} /-/ \mathrm{i} / \mathrm{/e} /-/ \mathrm{y} /-/ \mathrm{w} /$

IV к.: $\quad / \mathrm{o} /-/ \mathrm{a} /-/ \mathrm{i} /-/ \mathrm{e} /-/ \mathrm{w} /-/ \mathrm{y} /$;

P: $\quad \mid \mathrm{a} /-/ \mathrm{e} /-/ \mathrm{o} /-/ \mathrm{i} /-/ \mathrm{w} /-/ \mathrm{y} /$.

Сравнение с данными русских аудиторов выявляет, что коэффициенты корреляции растут по мере овладения языком: $\rho=0,54$ на I к. и $\rho=0,71$ на III и IV к. Значит, немцы обонх корпусов распознают сами ударные гласные всё более так, как носители русского языка - т.е. в соответствии с интенсивностью и частотностью гласных. Но в отличие от русских ии., немцы корп. Б воспринимают более закрытые гласные лучше более открытых - /o/ лучше /a/, /i/ лучше /e/.

Рис. 55 б. Правильное опознание признака" ударная гласная фонема" (кopn. Б)

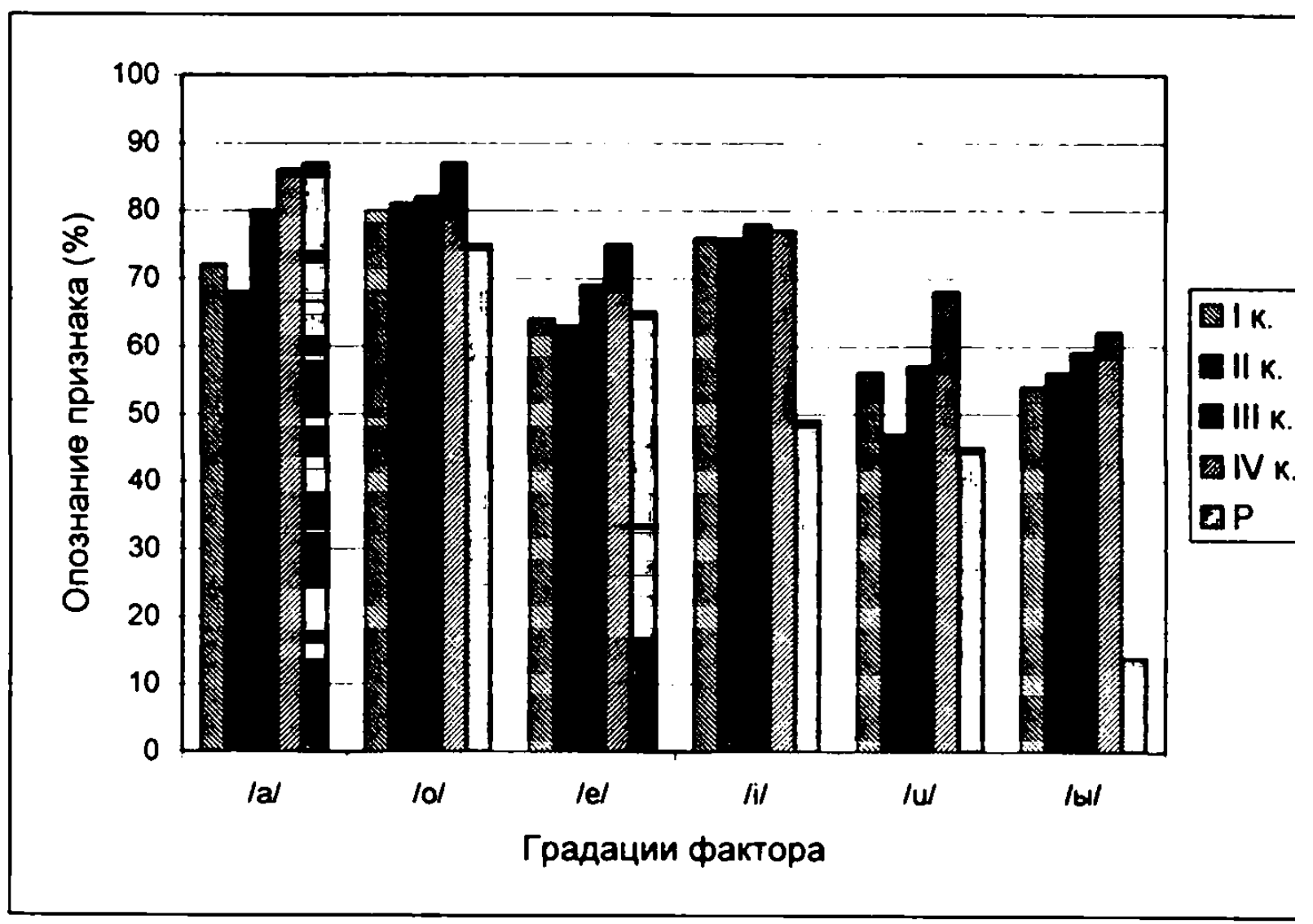

В обоих корпусах опознание фонемы /о/ отличается высокой стабильностью. В материале /o/ встречается в основном после твёрдых согласных. Можно предположить, что перцептивные эталоны гласных после твёрдых согласных попадают в зону сходства соответствующих немецких гласных ${ }^{53}$. Это, в свою очередь, способствует опознанию русских

${ }^{53}$ О зонах сходства см. [Джаларидзе 1985:53 -54]. 
гласных. Аллофоны гласных в соседстве с мягкими согласными воспринимаются, видимо, хуже потому, они не входят в зоны сходства гласных родного языка ии. Соответствующие перцептивные эталоны должны быть сформированы заново. Но как более молодые и менее прочные единицы, они менее помехоустойчивы.

Замены ударных гласных повторяют картину, полученную в корп. А (рис. 39 б). Но следует отметить, что замены со среднего подъёма на верхний для ии. корп. Б более частотны, чем для ии. корп. А. Замены же на гласные более низкого подъёма наблюдаются в корп. Б несколько реже. Очевидно, средний подъём установлен ещё менее прочно.

Итак, в обоих корпусах результаты по восприятию гласных дают неоднозначную картину. Особенно в заменах проявляется интерференция родного языка ии. В целом перцептивная база русского языка сформирована ещё недостаточно прочно.

Перейдём к анализу признака "консонантный козффициент", который характеризует слово комплексно. Поэтому интересно, что фактор и в МО ии. корп. Б более значим, чем другие фонетические факторы. При этом его влияние ещё возрастает к IV к. (табл. 16).

С одной стороны, фактор может действовать акустически. Это наблюдается у носителей русского языка и у ии. корп. А. Они опознают лучше те слова, в которых число гласных преобладает над числом согласных. С другой стороны, признак может отражать прогноз наиболее вероятной структуры. Напомним, что средний консонантный коэффициент в русском языке равен примерно 1,4. Данные для немецкого языка колеблются между 1,7 и 1,8. Следовательно, наиболее частотные по этому признаку слова могут восприниматься лучше.

Поведение фактора в корп. Б показывает смену стратегий: если на I и II к. опознание отражает скорее опору на вероятностный прогно3, то на III и IV к. решающую роль играет акустическая характеристика слов (рис. 56). Это согласуется с предположением о том, что вероятностный прогноз усиливается в более тяжёлых условиях приёма. При этом вероятностный прогноз может быть связан не столько с изучаемым, сколько с родным языком ии. Наоборот, опора на акустические признаки стимулов предполагает более тонкие перцептивные навыки, которые, очевидно, возникают прежде всего во время пребывания в среде носителей изучаемого языка. 
Рис. 56. Зависимость опознания слов от консонантного коэффичиента (корп. Б)

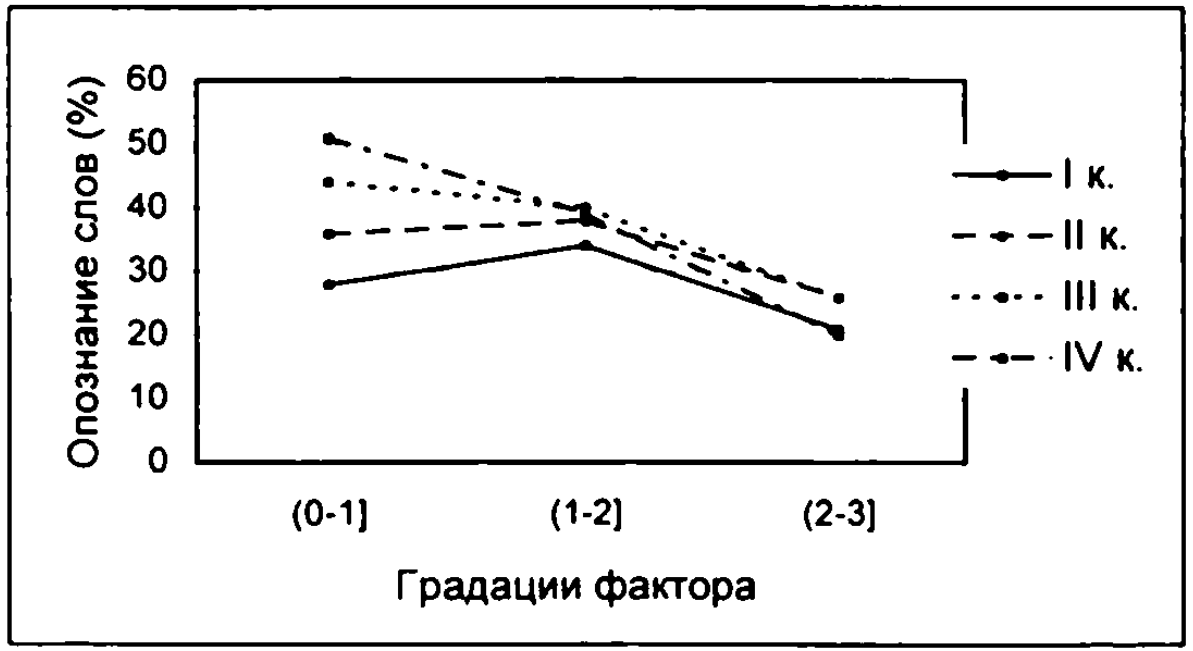

С фонемным уровнем связан также признак "количество консонансов". Обращение к факториальной иерархии показывает, что, за исключением IV к., влияние этого фактора в МО ии. корп. Б слабее, чем Е МО носителей русского и немецкого языков и ии. корп. А. Так же, как Е корп. А, фактор ведёт себя достаточно своеобразно (рис. 57). Это подтверждает мысль о его несамостоятельности. Только на I и III к. ии. опознают слова с двумя консонансами несколько лучше слов других градаций. То же самое зарегистрировано на V к. включённого обучения.

В целом можно заключить, что ии. корп. Б не удаётся в доста. точной мере опираться на консонансы. Этот вывод ещё укрепляется если учесть, что количество консонансов соотноситься с длиной слоЕ (89\% слов с двумя и более консонансами состоит из трёх и болеє слогов; в градации "0" это лишь 42 \%). Следовательно, правильно воспринимаются чаще всего слова без консонансов.

Анализ роли фактора "начальный звук" показывает, что и в МО ии. корп. Б этот признак относиться к наименее значимым (табл. 16). Тем не менее обнаруживается тенденция к лучшему опознанию слов с начальной гласной фонемой. Анализ замен показывает, что начальный гласный является стабильным элементом. На IV к. $65,5 \%$ неправильных реакций на слова с начальной гласной фонемой начинается с гласной же фонемы. При этом в большинстве случаев замены сохраняют фонемную принадлежность начального гласного. 
Рис. 57. Восприятие слов в зависимости от количества консонансов (корп. Б)

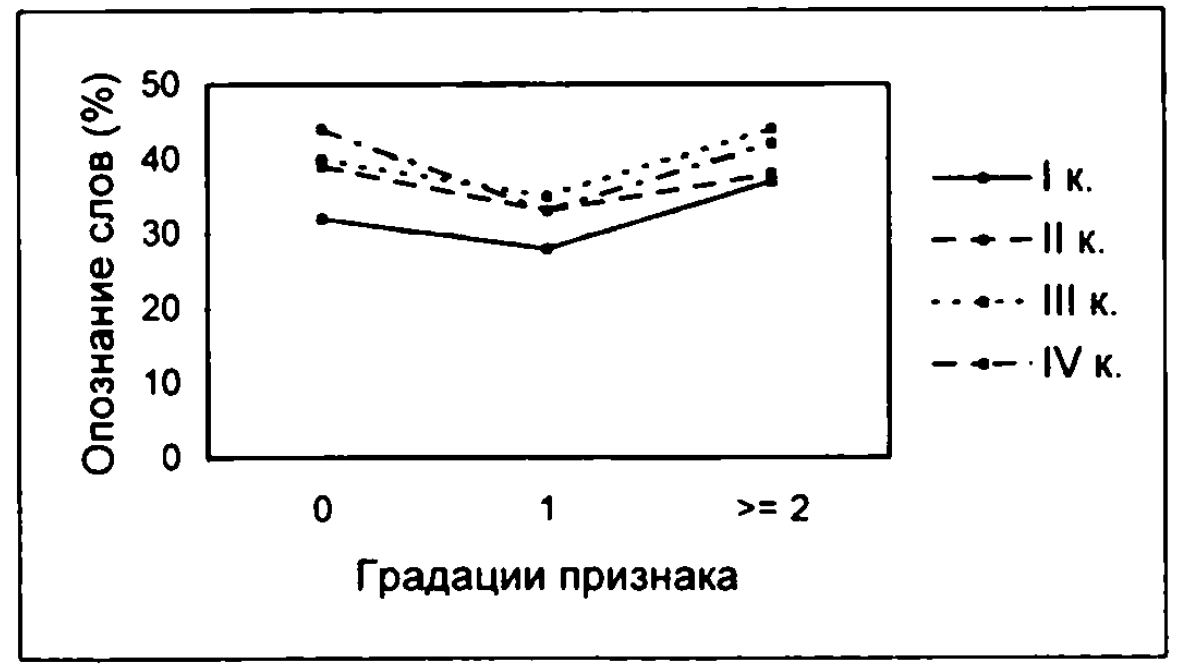

Анализ роли фактора "начальный звук" показывает, что и в МО ии. корп. Б этот признак относиться к наименее значимым (табл. 15). Тем не менее обнаруживается тенденция к лучшему опознанию слов с начальной гласной фонемой. Анализ замен показывает, что начальный гласный является стабильным элементом. Ha IV к. $65,5 \%$ неправильных реакций на слова с начальной гласной фонемой начинается с гласной же фонемы. При этом в большинстве случаев замены сохраняют фонемную принадлежность начального гласного.

\subsection{7 Дифференцнальные признаки}

Ии. корп. Б опираются на ДП сильнее, чем это наблюдается у ии. корп. А и у носителей русского и немецкого языков. Об этом свидетельствуют достаточно высокие для факторов данного уровня значения $\mathrm{r}^{2}$ (табл. 15). Видимо, ии. корп. Б вслушиваются больше в предъявляемый им материал, поскольку речь носителей языка для них в целом менее привычна и перцептивные навыки менее сформированы, чем у ии. корп. А.

В этой связи следует обратить внимание на динамику в поведении ДП. Она отчётливо прослеживается на средних от рангов (см. п. 5.3) и обусловлена прежде всего действием факторов "твёрдость - мягкость" и "звонкость - глухость". Влияние этих признаков очень высоко в МО на I и II к. (ранги 5-6,5). Лишь после стажировки в языковой среде оно заметно уменьшается. Таким образом, ещё раз подтверждается, что накопленный в языковой среде речевой - в частности, перцептивный опыт уменьшает субъективную сложность условий приёма.

Итак, ведущие факторы признакового уровня совпадают в МО немецких ии. обоих корпусов. Общая тенденция обнаруживается также в 
результатах восприятия: как правило, лучше всего опознаются слова смешанной градации (рис. 58-61).

Некоторое отклонение от общей тенденции проявляется в факторе "смычность - щелевость" (рис. 59). На III и IV к. лучше всего опознаются те слова, которые содержат в основном щелевые согласные. Аналогичный факт обнаружен на V к. корп. А. Возможно, это в какой-то степени связано с тем, что щелевые несколько длиннее смычных [Фонетика спонтанной речи 1988:216]. Но поскольку носители русского языка лучше опознают слова противоположной градации, можно также считать, что здесь проявляются другие, нефонетические факторы.

Восприятие крайних градаций признака "твёрдость - мягкость" повторяет ту же тенденцию, которая была найдена для корп. А: слова, в которых преобладают мягкие согласные, воспринимаются лучше слов с преимущественно твёрдыми согласными (рис. 61). Заметное сближение в опознании крайних градаций и, соответственно, ослабление контрастности мягких согласных наблюдается после стажировки. Это логично, поскольку контакт с носителями языка способствует формированию адекватных перцептивных эталонов.

На фоне вышеизложенных фактов можно сделать два практических вывода. Во-первых, при составлении материала для развития перцептивных навыков должно быть учтено, что слова смешанных градаций воспринимаются лучше других. Во-вторых, следует ешё раз подчеркнуть, что перцептивные навыки нужно развивать на материале речи носителей языка.

Рис. 58. Восприятие слов в зависимости от признака "цумность - сонорность" (корп. Б)

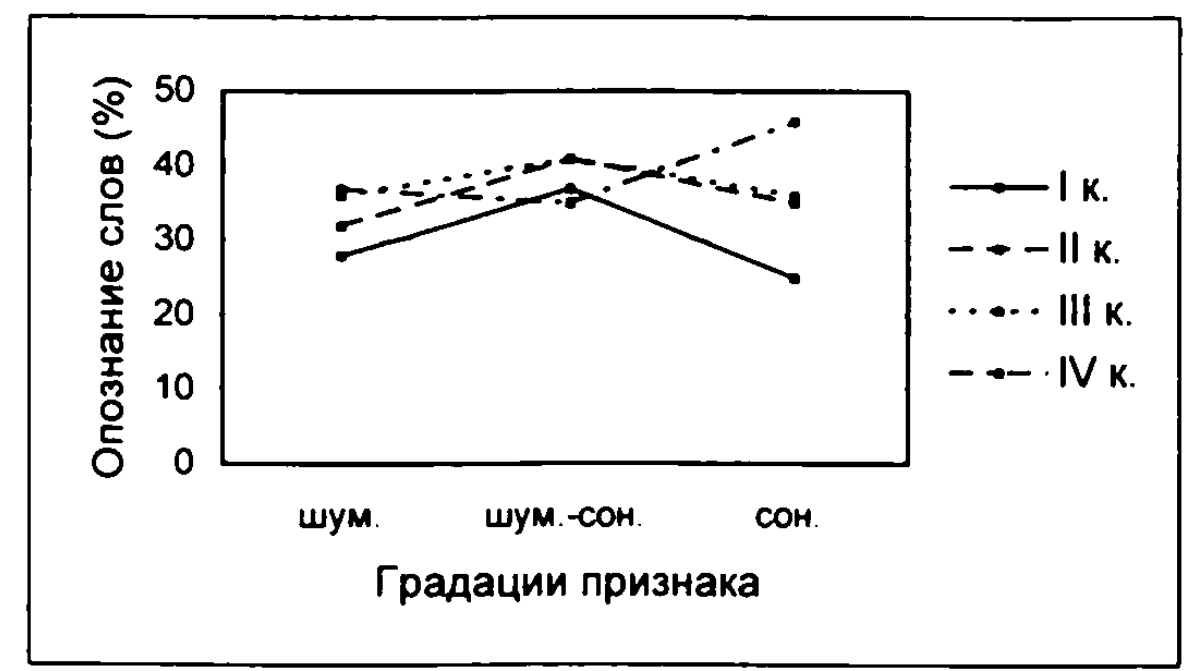


Рис. 59. Восприятие слов в зависимости от признака "смычность - щелевость" (корп. Б)

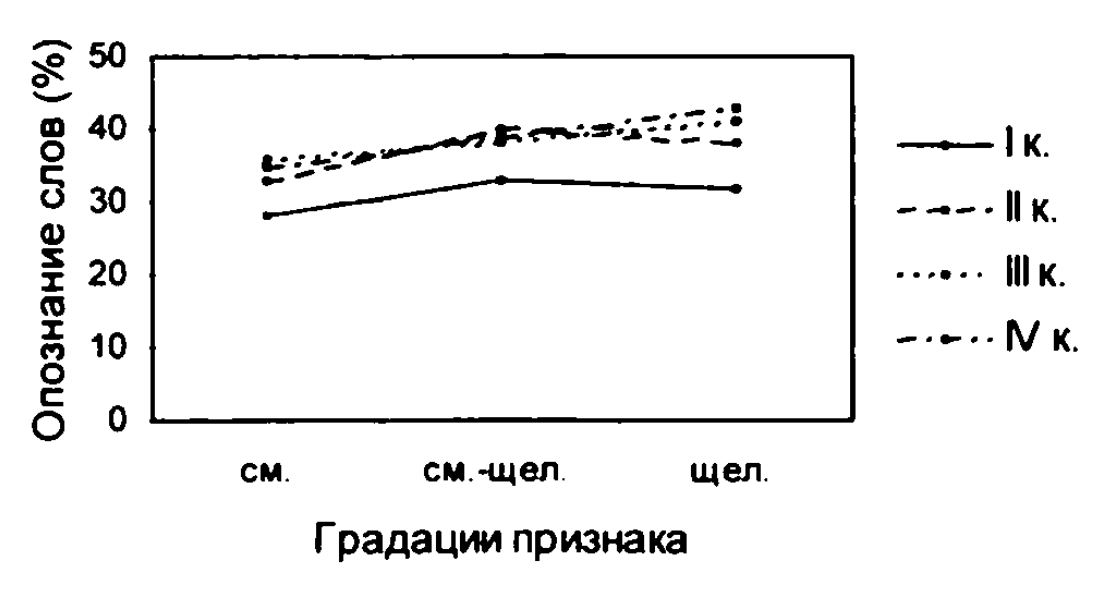

Рис. 60. Восприятие слов в зависиности от признака "звонкость - глухость" (корп. Б)

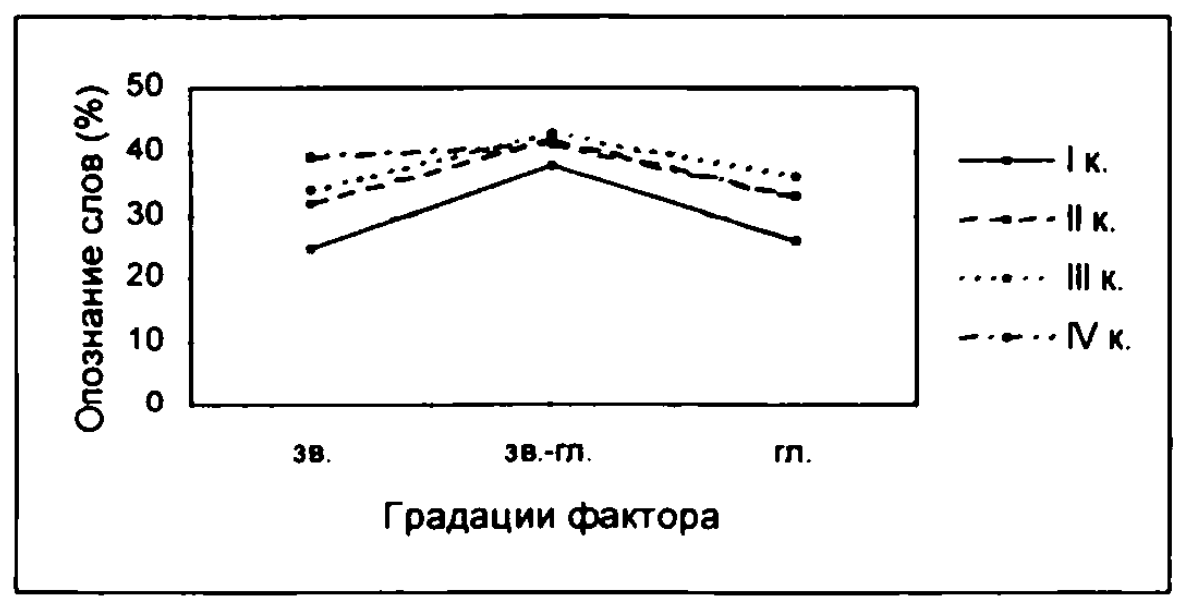

Рис. 61. Восприятие слов в зависиности от признака "твёрдость - мягкость" (корп. Б)

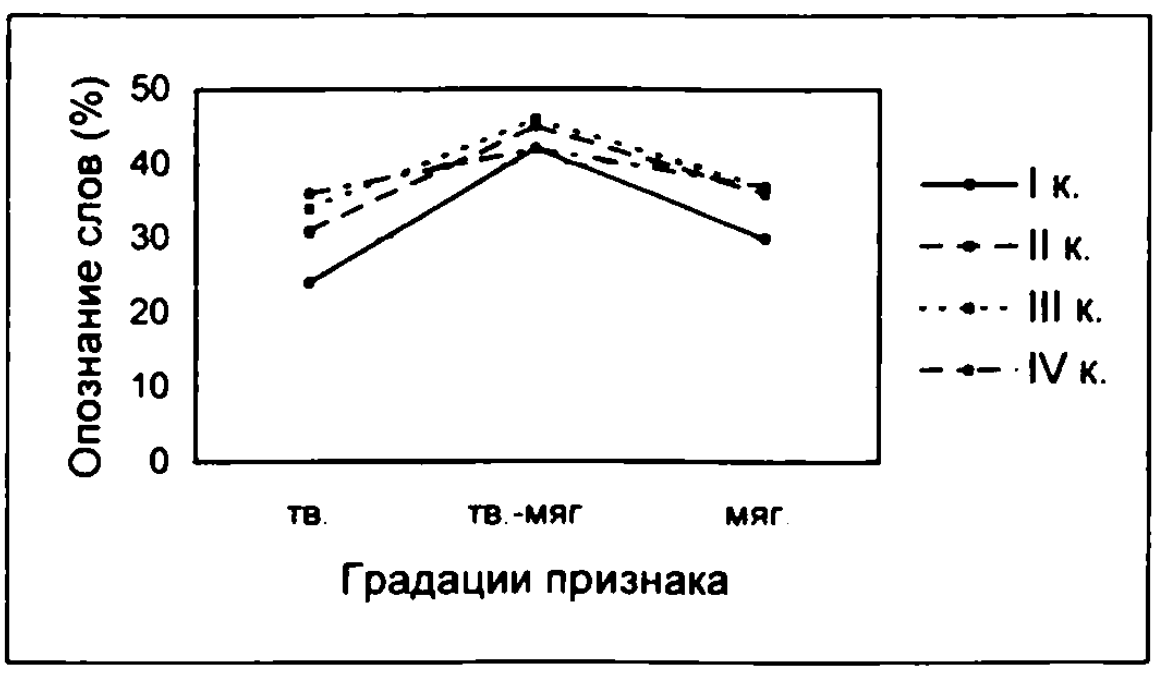




\section{6 Анализ воспрнятия незнакомых слов}

На фоне вышеизложенных результатов особый интерес представляет восприятие незнакомых слов. Оно анализируется на основе реакции ии. корп. Б, которые по сравнению с ии. корп. А обладают меньшим рехевым опытом и лексическим запасом.

На I и IV к. корп. Б в дополнительном опросе были определелы незнакомые ии. слова (НЗС). Слово считалось незнакомым в том случде, если больше одной трети ии. не знали ег. На I к. таких слов оказалссь 54. Иx среднее правильное восприятие составило $7,3 \%$. На IV к. имелось 23 незнакомых слова, среднее опознание которых $-5,2 \%$.

Массивы незнакомой лексики подверглись отдельному диспсрсионному анализу. Результаты расчётов представлены в табл. 18.

Таб.лица 18. Нерархия факторов при восприятии незнакомых слов (I и IV к. корп. Б); ранговая последовательность $(R)$ согласно величине показателя степени влияния ,

\begin{tabular}{|c|c|c|c|c|}
\hline \multirow[t]{2}{*}{ Фактор } & \multicolumn{2}{|c|}{ I к. } & \multicolumn{2}{|c|}{ IV $\kappa}$. \\
\hline & $r^{2}$ & $\mathbf{R}$ & $r^{2}$ & $\mathbf{R}$ \\
\hline$F_{06}$ & 0,0139 & 2 & 0,0030 & 14 \\
\hline$F_{\mathrm{cyo}}$ & 0,0070 & 5 & 0,0268 & 2 \\
\hline Часть речи & 0,0423 & 1 & 0.0034 & 12 \\
\hline Длина в слогах & 0,0025 & 10 & 0,0063 & 9 \\
\hline Длина в морфемах & 0,0020 & 13,5 & 0,0072 & 7 \\
\hline $\begin{array}{l}\text { Количество слого- } \\
\text { морфемных стыков }\end{array}$ & 0.0051 & 7 & 0.0061 & 10 \\
\hline Ритмика $\mathrm{H}-\mathrm{C}-\mathrm{K}$ & 0.0036 & 8 & 0,0010 & 15 \\
\hline Ударная гласная & 0,0117 & 3 & 0.0120 & 4 \\
\hline $\begin{array}{l}\text { Консонантный } \\
\text { коэффициент }\end{array}$ & 0,0101 & 4 & 0.0130 & 3 \\
\hline Количество консонансов & 0.0011 & 15 & 0.0032 & 13 \\
\hline Начальный звук & 0.0061 & 6 & 0,0097 & 5 \\
\hline Шумность - сонорность & 0.0023 & 11 & 0.0071 & 8 \\
\hline Смычность - щелевость & 0,0022 & 12 & 0,0087 & 6 \\
\hline Звонкость - глухость & 0.0020 & 13.5 & 0.0281 & 1 \\
\hline Твёрдость - мягкость & 0.0026 & 9 & 0.0055 & 11 \\
\hline
\end{tabular}


В табл. 19 приводятся коэффициенты ранговой корреляции с другими MO. На I к. связь с общим МО выступает отчётливо, на IV к. она практически отсутствует. Это говорит о том, что на IV к. сформированы разные MO в зависимости от степени знакомства с материалом. Показательно, что на обоих курсах корреляция с родным языком сильнее для того механизма восприятия, который был определён в наиболее трудных условиях восприятия (H2). Противоречивую картину даёт корреляция с MO носителей русското языка. Отрицательная связь на IV к. Является прежде всего следствием высокого влияния признака "звонкость - глухость" в механизме восприятия НЗС, что можно трактовать как интерференцию родного языка.

Таблича 19. Матрица иитеркоррелячии МО, определенных д.яя незнакомых слов HЗС., корпус Б. с оругими МО

\begin{tabular}{|l|l|l|}
\hline MO & H3C I K. & H3C IV K. \\
\hline I K. & +0.448 & - \\
\hline IV K. & - & $+0,080$ \\
\hline HI & +0.092 & $+0,323$ \\
\hline H2 & $+0,256$ & $+0,398$ \\
\hline P & $+0,286$ & $-0,222$ \\
\hline
\end{tabular}

Учитывая специфику материала, мы абстрагируемся при рассмотрении $\mathrm{MO}$ от факторов " $\mathrm{F}_{\mathrm{o \sigma}}$ " и " $\mathrm{F}_{\mathrm{cy6}}$ ". Особенность восприятия Н3С состоит на обоих курсах в том, что по сравнению с общим МО возрастает опора на "начальный звук" и уменьшается опора на "длину в слогах".

Основная разница между восприятием $\mathrm{H} 3 \mathrm{C}$ на I и IV к. видится в том, что ии. IV к. опираются сильнее на дистинктивные признаки согласных (средняя от рангов равна 6,5 на IV к. и 11,4 на I к.). Опора на "часть речи", наблюдающаяся не только на I к. при восприятии НЗС, но и при восприятии всего массива слов ии. корп. Б, уходит на IV к. на задний план. Зато увеличивается значение фактора "длина в морфемах" по отношению к "длине в слогах". Сравнение с I к. подтверждает, что опора на морфемы реализуется лишь на достаточно высоком уровне знания языка. На IV к. уменьшается также опора на ритмическую структуру, описываюшую слово скорее как целое. Всё это говорит о том, что по сравнению с I к. на IV к. усиливается поэлементный анализ незнакомых ии. слов. Этому, видимо, способствует более совершенный на старших курсах механизм восприятия иноязычных слов и, в частности, более совершенная перцептивная база.

Подтверждается, что "восприятие незнакомых и опознание знакомых конфигураций - это разные процессы" [Шехтер 1981:168] в том 
12 in

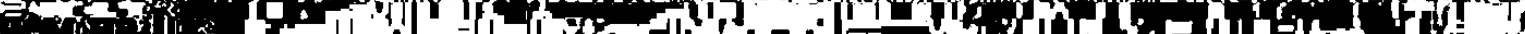

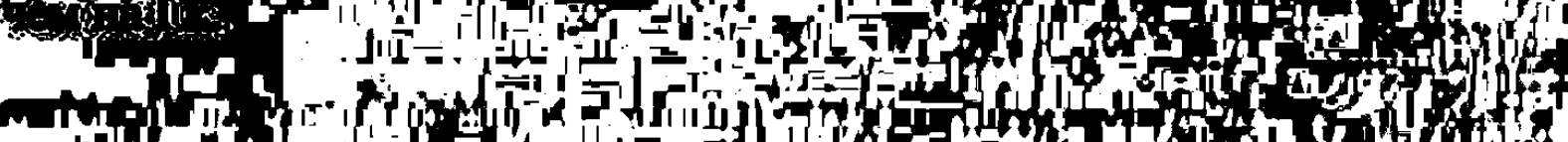

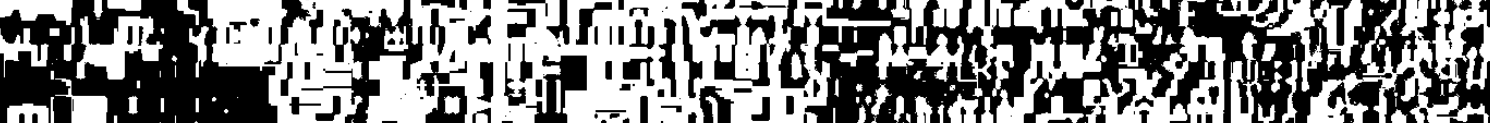

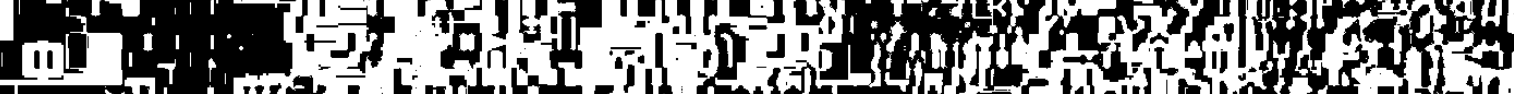
-

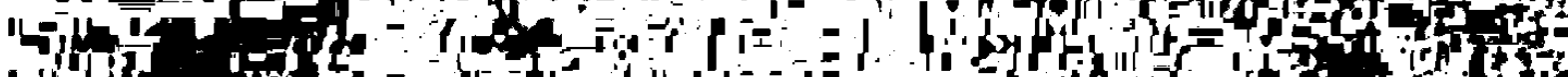

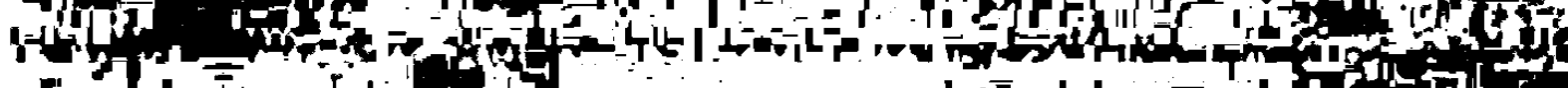

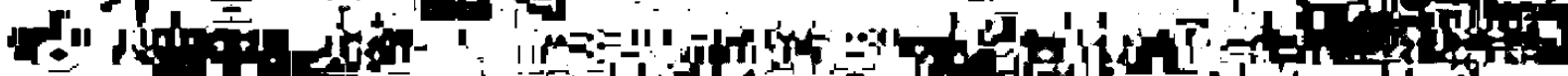

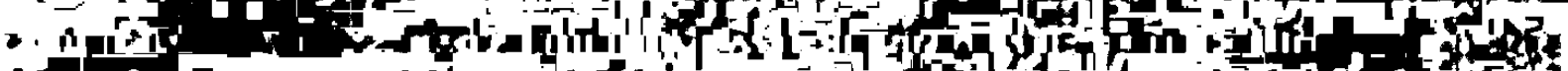

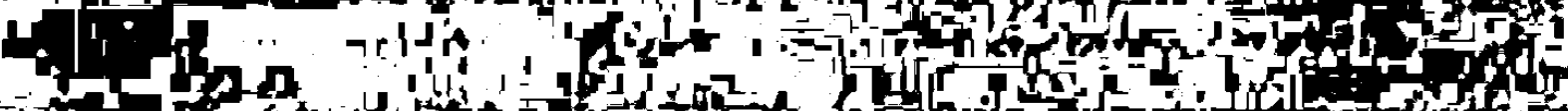

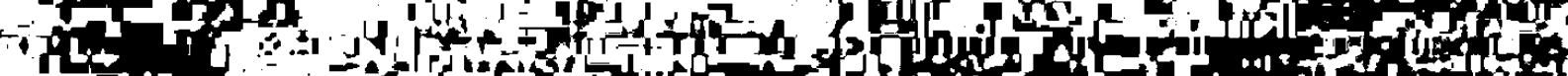

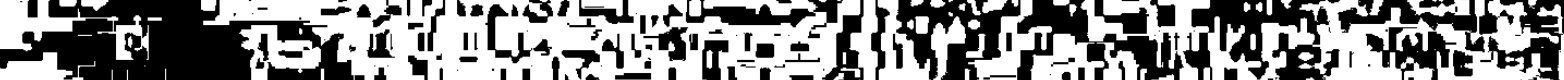
1) 1 . a

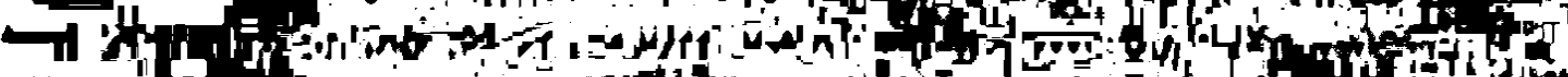

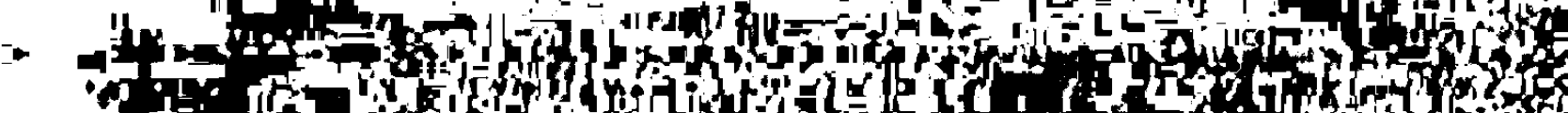

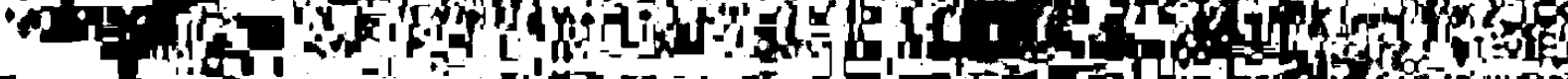

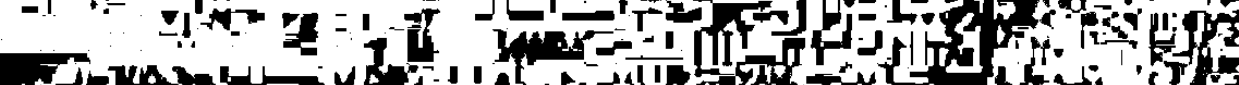

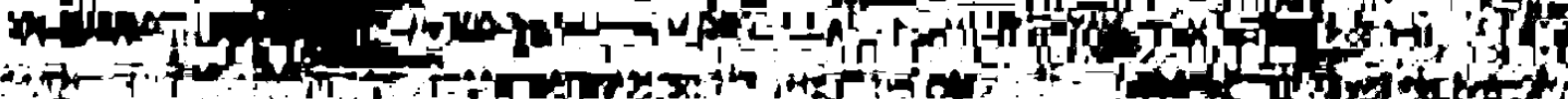
9 .

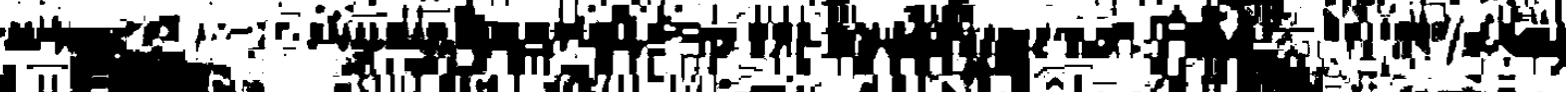
c

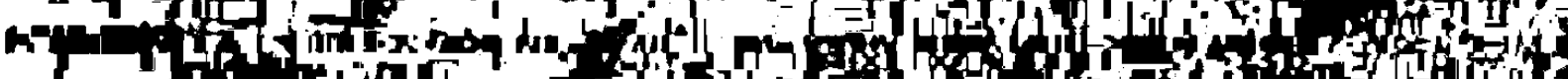

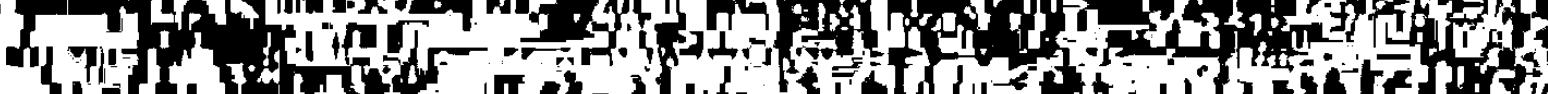
IN

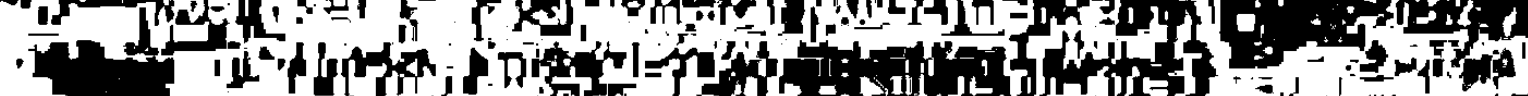
I 8 is.

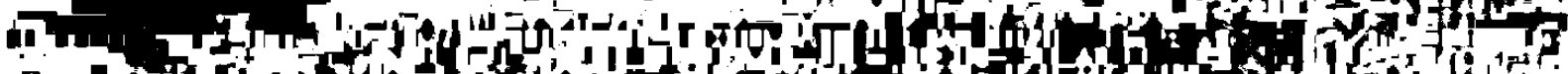

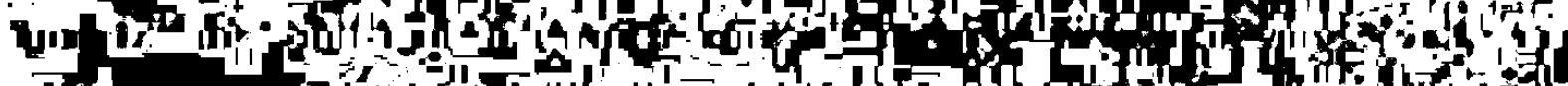

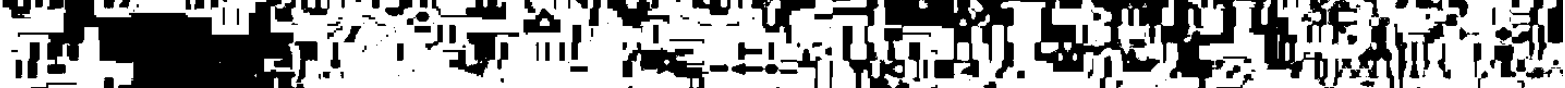
1.m.

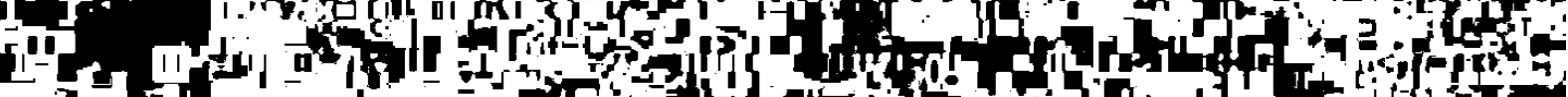
$\therefore$.

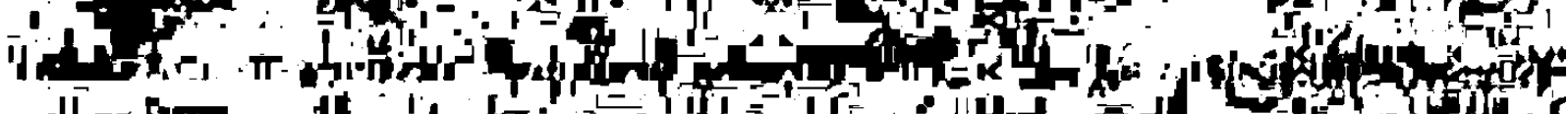
1 


\section{6. ОБСУЖДЕНИЕ РЕЗУЛЬТАТОВ И ВЫВОДЫ}

\section{1 Гипотеза об уннверсальности механизма опоры прн воспрнятин нзолированного слова}

В предыдущих главах было показано, что аудиторы-немцы опираются в родном и изучаемом языках на сходные комплексы существенных лингвистических признаков. Аналогичные блоки факторов обнаружены при восприятии русских и английских слов носнтелями соответствующих языков, а также при восприятии французских, немецких и английских слов русскими. О близости МО свидетельствуют козффициенты ранговой корреляции: для немецкого и русского языков $\rho=+0,66$, для русского и английского языков $\rho=+0,85$, а для английского и немецкого языков $\rho=+0,87$.

Расхождения в наборе существенных лингвистических признаков возникают прежде всего за счёт типологических особенностей того или иного языка, например, разной значимости факторов "твёрдость - мягкость" и "количество слого-морфемных стыков" в русском и немецком языках.

Тот факт, что аудиторы в разных языках опираются на примерно одинаковые лингвистические признаки материала, и иерархии факторов достаточно сходны, позволяет предполагать психолингвистическую универсальность МО в языках исследуемого типа. Она прослеживается и в самой структуре MO: лингвистические признаки более высоких уровней (например, " $F_{\text {об }}$ ", "F суб", "количество квазиомонимов", "длина в слогах", "длина в морфемах") оказывают на восприятие слов значительно больше влияния, чем признаки более низких уровней, в частности, ДП согласных (см. также [Ломов 1966:354]).

Вместе с тем, набор существенных лингвистических признаков и вес факторов МО могут меняться в зависимости от условий восприятия. Это, видимо, тоже универсальный механизм - см. также [Штерн 1987:73].

Показательно, что ии. корп. А опираются на меньшее число существенных лингвистияеских признаков, чем группы корп. Б (по курсам в корп. А: $11,11,12$; а корп. Б: $15,10^{54}, 13,15$ существенных факторов). Наличие большого числа опорных единиц говорит о субъективной сложности, о меньшей автоматизированности процесса восприятия [Зинчен-

\footnotetext{
$\$ 4$ II к. корп. Б ведёт себя своеобразно, что выражается также в отсутствии корреляции с МО носителей русского и немецкого языков: ср. табл. 17.
} 
ко 1964$]^{55}$. Следовательно, восприятие русских слов сложнее для тех ии., которые обучаются преимущественно в неязыковой среде.

\section{2 Общность и специфика стратегий восприятия в родном и изучае- мом языках}

Результаты работы подтверждают, что аудиторы опираются на лингвистические признаки всех уровней, независимо от конкретных условий приёма. Значит, в процессе восприятия изолированных слов активизируется знание языка в целом, охватывающее самые разные области - от механизма вероятностного прогнозирования до элементарных единиц перцептивной базы.

Во всех группах ии. параллельно используются признаки, характеризующие слова целостно или по частям. Но как в родном, так и в изучаемом языке субъективная сложность восприятия определяет, значение каких факторов усиливается и, следовательно, какая из стратегий восприятия может превалировать. Соответственно, наблюдаются параллели между восприятием немецких слов в очень сильном шуме и воеприятием русских слов на относительно низком уровне владения языком (I и II к. корп. Б). Они проявляются в низком значении фактора "длина в слогах" и относительно высокой роли признака "длина в морфемах", а также в том, что значение ряда ДП согласных существенно возрастает по сравнению с более лёгкими условиями приёма.

При изменении условий приёма в поведении ряда признаков отражается смена стратегий восприятия. Так, низкое значение фактора "длина в слогах" свидетельствует о скорее поэлементной стратегии восприятия, в то время как повышение роли фактора в МО говорит об усилении целостной стратегии восприятия. Смена стратегий восприятия прослеживается также в поведении признака "консонантный коэффициент": ии. I и II к. корп. Б опираются скорее на вероятностный механизм; реакции же ии. III и IV к. определяются прежде всего акустической характеристикой слов.

Итак, стратегия восприятия и критерии их выбора принципиально тождественны в родном и изучаемом языках. Это позволяет осуществлять положительный перенос в одинаково трудных условиях.

Особенность восприятия на изучаемом языке заключается в том, что иностранцы в ряде случаев скорее, чем носители языка, готовы отказаться от поэлементного распознавания стимулов. Это предположение подтверждается реакциями неносителей языка на псевдослова [Данилов

5s См. также [А.Зиндер, Штерн 1986; Штерн. Элькин 1989]. 
1985], а также некоторыми наблюдениями в настоящей работе (см. п. 5.2). Важную роль при этом играют повышенная опора на вероятностное прогнозирование, в частности, на частоту словоупотребления. Устано-

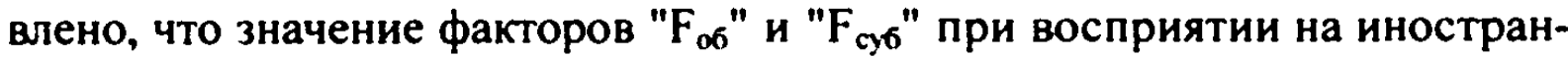
ном языке существенно превосходит весомость их в МО носителей языков.

По данным Д. и М. Бродбентов, значение частоты усиливается в тех случаях, когда контур сохранён, а части его сильно маскированы [ср. Veličkovskij 1988:149]. Таким образом, бо́льшая чувствительность иностранцев к шумам сводится прежде всего к тому, что позднее и, очевидно, недостаточно прочное формирование элементарных перцептивных эталонов изучаемого языка - в частности, фонем - приводит к их меньшей помехоустойчивости. Соответственно, с одной стороны, ии. опираются в большей степени на контур, т.е. на гештальтное отображение стимула, а с другой стороны, на морфемы, представляющие значимые элементы слова и выступающие как "субгештальты". В этой связи следует также указать на тот факт, что в изучаемом языке признак "ударная гласная фонема" играет значительно меньшую роль, чем в МО носителей языков.

В работе показано, что зрительные эталоны, сохраняющиеся в долговременной пямяти ии., могут компенсировать перцептивные трудности. Поэтому, видимо, необходимо тестировать степень сформированности навыков аудирования на незнакомом языковом материале.

\section{3 Динамика формирования механизма опоры на изучаемом языке}

В работе показано, что по мере овладения языком происходит упорядочивание факторов восприятия и сближение с механизмами носителей родного и изучаемого языков (табл. 10, 17). Значит, функциональная нагрузка изучаемого языка как помехи восприятия уменьшается с растущим уровнем владения языком. Параллельно увеличивается суммарное влияние исследуемых признаков. Это говорит о том, что опора на лингвистические признаки усиливается и соответствующая информация используется более успешно.

Анализ иерархии признаков и поведение градаций факторов выявляет сближение МО ии. именно с русским языком. Наибольшая корреляция с $\mathrm{MO}$ носителей русского языка наблюдается на $\mathrm{V}$ к. корп. $\mathrm{A}$ $(\rho=+0,65)$. На этом уровне владения языком субъективные условия восприятия таковы, что можно осуществлять наиболее полное приближение к MO носителей языка как определённого качества владения языком. 
В корп. Б наивысшее сближение с МО русских отмечается на III к., непосредственно после шестимесячной стажировки в России $(\rho=+0,44)$. Следует особо подчеркнуть, что отсутствие активной речевой практики на IV к. корп. Б приводит даже к некоторому ухудшению корреляции по сравнению с III к., хотя после более длительной стажировки в языковой среде ожидался рост корреляции.

В табл. 20 представлены коэффициенты корреляции, полученные в результате соотнесения механизмов опоры корпусов А и Б.

Таблица 20. Козффичиенты ранговой корре.ияци групп корпусов $А$ и $Б$

\begin{tabular}{|c|c|c|c|c|}
\hline \multirow{2}{*}{ A } & \multicolumn{4}{|c|}{ B } \\
\cline { 2 - 5 } & I & II & III & IV \\
\hline I & 0.614 & 0,632 & 0.730 & 0,790 \\
III & 0.792 & 0.691 & 0.896 & 0.820 \\
V & 0.794 & 0,501 & 0.883 & 0.770 \\
\hline
\end{tabular}

Наибольшей близостью MO характеризуется III к. корп. А и III к. корп. Б. Высока также корреляция между IV к. корп. Б и III к. корп. А. Это соответствует данным корреляции с МO носителей русского языка. Неожиданной является высокая корреляция I к. корп. Б с МО III к. и V к. корп. А. Большое значение этих коэффициентов корреляции не отражает истинного положения дел: ин. I к. опираются гораздо сильнее на ДП согласных и гораздо меньше на "длину в слогах", чем это имеет место в группах корп. А.

Итак, подтверждается, что длительное пребывание в языковой среде способствует сближению с МО носителей изучаемого языка. Вместе с тем, результаты корреляции позволяют сделать только некоторую внешнюю предварительную оценку степени сформированности механизма восприятия. Они должны быть дополнены качественным анализом поведения факторов и опознания градаций.

\section{4 Особенности поведения факторов в механизме воспрнятня на изучаемом языке}

Мы уже отметили, что при восприятии иноязычных слов увеличивается роль факторов " $F_{\text {об" }}$ и " $F_{\text {суб }}$ ". Усиление опоры на частоту словоупотребления можно рассматривать как индикатор сложности приёма [Штерн [987a:73]. Поэтому примечательно, что значение этих признаков в корп. Б выше, чем в корп. А. Следует также указать на то, что в результате живой разносторонней речевой практики уменьшается значение фактора " $F_{06}$ " по отношению $к$ " $F_{c y 6} "$. Это наблюдение подтверждает то, что 
оценки "F суб" передают речевой опыт индивидов более полно, чем данные "Fo6".

Повышенное значение фактора "часть речи" обнаруживается не только у иностранных учащихся, но также у русских детей как тугоухих, так и нормальнослышаших [А.Зиндер, Штерн 1986]. В ситуации изолированного предъявления слов данные группы ии. усиливают опору на частеречные маркеры. Сам факт установки на такие внешние приметы в онтогенезе уже известен [Леонтьев 1965; Слобин 1984]. Можно предполагать наличие некоторых параллелей между восприятием детей и иностранцев, которых объединяет то, что они находятся в прицессе становления языковой компетенции. ${ }^{56}$ В этой связи следует отметить, что по мере овладения языком значимость фактора "часть речи" уменышается.

Особенности восприятия иноязычных слов проявляются также в соотношение факторов " длина в слогах" и " длина в морфемах". В механизмах носителей языков опора на слоги преобладает над опорой на морфемы. Такое же соотношение признаков наблюдается на V к. корп. A. На I к. корп. А проявляется примерно одинаковое влияние обоих факторов на восприятие, между тем как на III к. корп. А и на всех курсах корп. Б значение признака "длина в морфемах" превалирует над значением фактора "длина в слогах". Напомним, что в более трудных условиях носители немецкого языка тоже опираются сильнее на морфемы, чем на слоги. Вместе м тем, опора на морфемы уже предполагает определённый уровень знания изучаемого языка, о чём также свидетельствуют результаты восприятия незнакомых слов.

Повышенная опора на морфемы согласуется с данными других авторов. В частности известно, что при толковании значения менее частотного, менее актуального слова производится анализ по его значимым компонентам [Сахарный 1989:65]. Дети, которые усваивают родной язык, стремяться к морфологизации слов [Чуковский 1988] и соотносят слово с фонетически близким, но уже знакомым и осмысленным словом [Reimann 1986].

Результаты работы подтверждают мысль о том, что значение избыточности информации для правильного восприятия иноязычных стимулов возрастает по отношению к родному языку. Обнаружено, что немецкие учащиеся воспринимают предкорневые морфемы хуже посткорневыХ, в то время как восприятие морфем носителями языков определя-

\footnotetext{
${ }^{56}$ На наш взгляд. эти данные подчёркивают необходимость проведения исследований. которые должны выявить сходное и различное в процессе усвоения родного и второго языков - см. также [Esser 1988].
} 
ется, по-видимому, несколько другими факторами, чем местом морфем Е слове.

Итак, механизмы восприятия на иностранном языке отличаются некоторыми специфическими чертами, проявляющимися независимо от тоro, в какой среде происходит обучение языку. Они вызваны тем, что сам факт восприятия иностранного языка действует как помеха. Соответственно, сила этих черт характеризует степень трудности и, следовательно, уровень владения языком. Показательно, что даже на высоком уровне владения языком, сложившемся в результате пятилетнего пребывания в языковой среде, особенности восприятия иноязычного материала не исчезают полностью.

Описанные выше особенности восприятия немецких ии. отражают влияние родного языка в том смысле, что первичный, доминирующий язык тормозит, осложняет более позднее усвоение второго языка. Несмотря на длительный срок обучения, как вне языковой среды, так и внутри неё, ии. не достигают уровня совершенного владения изучаемым языком. Сказывается, видимо, то, что овладение родным языком в онтогенезе происходит в социально, психологически и нейрофизиологически более блатоприятных условиях.

Некоторые отклонения от механизмов восприятия носителей русского языка, наблюдаемых в обоих корпусах ии., говорят о непосредственной интерференции родного языка. Они сосредотачиваются на признаках фонетическото уровня и проявляются как в уподоблении элементов изучаемого языка эталонам первого, родного языка, так и в отклонении от эталонов второго языка (ср. [Нехай, Поплавская 1983]).

С этой точки зрения следует рассматривать замены ударных гласных русского языка, имеющие место во всех группах ии. Трудностями в восприятии элементов более сложной консонантной системы русского языка объясняется весьма низкая опора на консонансы, обнаруживающаяся до $\mathrm{V}$ к. корпуса $A$.

Фонетическая интерфереция на уровне ДП согласных прослеживается прежде всего в опоре на фактор "звонкость - глухость", которая несвойственна носителям русского языка.

Интерференция проявляется и в поведении градаций признака "твёрдость - мягкость". Она отражается в двояком контрасте, характеризующем прежде всего мягкие согласные. С одной стороны, имеется расхождение с перцептивной базой родного языка, где мягкие фонемы не представлены; а с другой стороны, возможно сходство с неадекватно сформированными в учебном процессе эталонами мягких фонем вто- 
poro языка. 57 Тот факт, что по мере овладения языком ослабевает контрастность мягких согласных, говорит о становлении адекватных перцептивных эталонов. Подтверждается, что развитие аудитивных навыков направлено на те признаки, которые в соответствующем языке выполняют смыслоразличительную функцию [Lindner 1977:26].

Отметим в этой связи, что опора на признаки фонетическото уровня требует известной степени сформированности перцептивной базы на изучаемом языке, о чём также свидетельствуют данные по восприятию незнакомых слов: на IV к. опора на дП гораздо сильнее, чем на I к. (табл. 19).

На наш взгляд, перцептивная интерференция родного языка проявляется также в восприятии ритмических контуров. По отношению к хореическим структурам наблюдается положительный перенос. Другие структуры, в частности, с заударными слогами, представляют для немцев значительные трудности. Это, видимо, обусловлено их непривычностью на фоне родного языка. ${ }^{58}$ Примечательно, что существенный прогресс в восприятии данных ритмических структур обнаруживается только у тех ии., которые длительное время обучались в языковой среде (корп. А).

Гаким образом, если учесть, что механизм восприятия затрагивает все уровни знания языка, представленные в изолированном слове. то фонетические признаки можно считать наиболее уязвимыми. Сказывается. очевидно, высокая степень автоматизированности соответствующих навыков, очень трудно поддающихся осознанию, контролю и воздействию. Тем не менее, по мере овладевания языком происходит формирование перцептивной базы изучаемого языка. Нахождение в среде носителей языка способствует этому процессу.

\section{5 Общее составление механизмов восприятия}

Итак, степень сформированности механизма восприятия оценивается на основе трёх критериев:

\footnotetext{
57 Основная разница между обучением русскому языку в школе и в вузе состоит в том. что в начале обучения русскому языку артикуляторные навыки на ролном языке прямым и "неискажённым" образом переносятся на изучаемый язык. Конечно. в процессе овлалення языком наб́людается некоторый артикуляционный прогресс. Вместе с тем. именно вузовское обучение стонт перед залачей корректировать пронзношение студентов [Müller 1984]. Ясно, что это в той же степени относится и к коррекции неправильных перцептивных эталонов. которой пока не уделяется особого внимания.

${ }^{58}$ Как известно. трудности проявляются не только в восприятии. но также в артикуляции слогов с редуцированными гласными.
} 
1. механизм опоры (иерархия факторов);

2. коэффициент ранговой корреляции;

3. опознание градаций факторов.

Они не могут быть формализованы в одной оценочной величине. Поэтому мы постараемся сопоставлять исследованные механизмы восприятия на базе обобщённых данных. Условная схема такова (рис. 62):

Рис. 62. Схема степени сформированности механизма восприятия в исследованных корпусах ии.

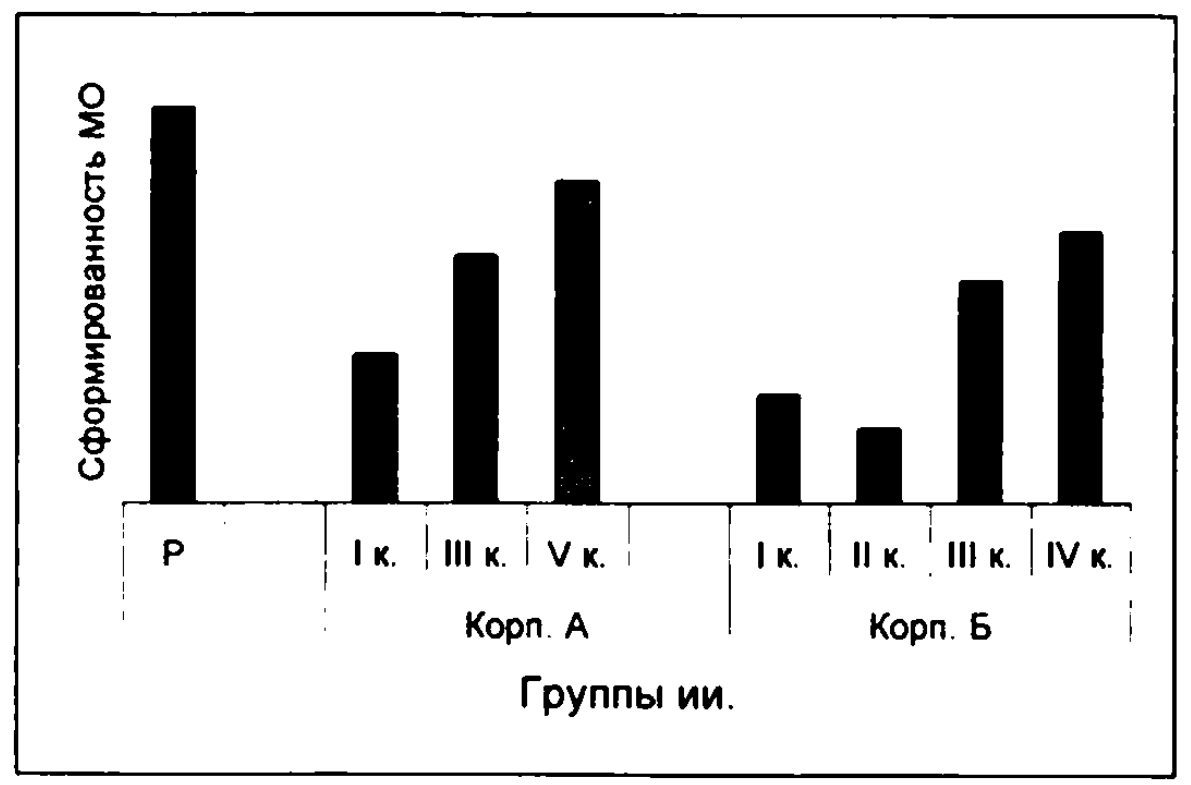

Динамика формирования механизма восприятия во многом определяется актуальным аудитивным опытом. Поэтому механизм восприятия ии. корп. Б развивается более автономно от других видов речевой деятельности. Стажировка в языковой среде способствует приближению к механизму восприятия носителей изучаемого языка.

В целом данная работа подтверждает зависимость качественного характера билингвизма от условий усвоения языка. Она была ранее определена в исследовании владения лексико-семантической системой изучаемого языка [Лэмберт, Гавелка, Кросби 1972]. Было установлено, что те ии., которые после общего этапа школьного обучения продолжают учиться в окружении носителей изучаемого языка, с большей лёгкостью достигают равновесия в уровне владения языками. Аналогичный вывод можно делать для формирования механизма восприятия. 


\section{6 Практические выводы}

Остановимся на некоторых выводах, которые можно сделать на основе проведённых экспериментов.

В работе обнаружено, что непосредственная интерференция родного языка проявляется прежде всего на уровне элементарных периептивных эталонов - фонем и ДП согласных, а также при восприятии ритмических структур. Поэтому делается вывод о том, что существует необходимость в специальной тренировке перцептивных навыков, независимо от того, где обучаются ии. [Krause, Stern 1988]. Это особенно важно потому, что навыки восприятия опережают навыки произнесения; как отмечает в этой связи Г. Линдер, приближение реализаций звуков учащимися к реализациям носителей языка происходит в сложном процессе усвоения языка, в котором особую роль играет актуальное восприятие [Lindner 1981:102].

Следует уделять внимание развитию навыков аудирования уже с начального этапа обучения. Практическим шагом в этом направлении являются требования новой Программы обучения русскому языку в средних политехнических школах ГДР [Lehrplan... 1988], предусматривающей специальную фонетическую подтотовку в пятом классе. Вместе с тем, результаты данной работы подтверждают, что нельзя ограничивать занятия фонетикой начальным уровнем овладения языком.

Рекомендуется проводить аудитивные упражнения сначала на материале элементарных елиниц речи, как слогов и слов, а затем включать также предложения и тексты [Desselmann 1983b; Штерн 1984]. На более высоком уровне владения языком можно проводить тренировку на фоне белого шума.

Представляется целесообразным сочетать развитие навыков аудирования с формированием навыков произнесения и письма. графической передачи фонем [Krause, Stern 1988]. Комплексный подход, который, например, применим при введении и закреплении лексики, позволяет включать упражнения по аудированию практически в любое занятие по русскому языку. При работе над лексикой должна быть учтена перцептивная сложность материала.

В целях формирования механизма восприятия предпочтительно использовать записи носителей литературной нормы изучаемого языка. Вместе с тем, очевидно, что основную роль в этом процессе играет речь преподавателя. Она должна соответствовать высоким фонетическим требованиям, что предполагает постоянную работу над произношением со стороны самих преподавателей. Это тем более важно, что имется и обратная связь: со временем ошибки учашихся находят отражение в артикуляции преподавателя [Zawadzka 1988]. Поэтому работа над фонетикой 
(как в плане восприятия, так и артикуляции) должно занять прочное место в системе повышения квалификации учителей и преподавателей.

Высокая опора на морфемы, которая характерна почти для всех ии., подчёркивает значение прочных знаний в области морфологии и словообразования изучаемого языка. Особое внимание следует уделять вариативности морфем русского языка, ero морфонологическим особенностям. Такие знания могут способствовать не только восприятию иноязычных слов. Они также помогают учащимся осознавать системность языка, и это безусловно облегчает усвоение его.

Восприятие сбалансированного материала на фоне белого шума показало свою пригодность в качестве метода тестирования. C его помощью может быть определена степень сформированности механизма восприятия на иностранном языке и через неё - уровень владения языком. Подчеркнём ещё раз, что выводы должны основываться на анализе как МО, так и поведения отдельных факторов. В качестве зкспериментального материала довольно хорошо зарекомендовали себя артикуляционные таблицы, составленные по методике А.С. Штерн [Штерн 1984].

В ходе работы были также предложены частные виды тестирования, опирающиеся на конкретные лингвистические признаки, например, "количество квазиомонимов" и "длина в слогах". Но они требуют дальнейшей разработки.

Поскольку рассмотрение механизма восприятия немецких слов немцами составило отдельную часть нашего исследования, подчеркнём, что практические рекомендации распространяются также на использование этих материалов в целях развития и тестирования навыков аудирования.

\section{7 Заключение}

Итак, в работе представлена статистическая модель формирования механизма восприятия иноязычных слов. Модель отражает динамику этого прочесса, определяемую сроком и средой обучения.

Механизм восприятия охватывает разные уровни знания языка, активизируемые в трудных условиях восприятия. Диагностичный характер модели, подтвердившийся в настоящем исследовании, позволяет её использовать в целях тестирования уровня владения языком. 


\section{7. СПИСОК ИСПОЛЬЗУЕМЫХ В РАБОТЕ СОКРАЩЕНИЙ}

DaF - Deutsch als Fremdsprache

$\mathrm{F}_{\mathrm{o6}}$ - объективная частота

$\mathrm{F}_{\text {cуб }}$ - субъективная частота

IRAL - International Review of Applied Linguistics

JASA - Journal of the Acoustic Society of America

ZPSK - Zeitschrift für Phonetik, Sprachwissenschaft und Kommunikation forschung

Г, гл. - глагол

ДП - дифференциальный признак

Ии. (ии.) - испытуемые

Корп. - корпус

Н - C - К - начало, середина, конец (о позиции словесного ударения)

М, мест. - местоимение

MO - механизм опоры

П, прил. - прилагательное

РЯЗР - Русский язык за рубежом

С, сущ. - существительное

Ч, числ. - числительное 



\section{8. СПИСОК ИСПОЛЬЗОВАННОЙ ЛИТЕРАТУРЫ}

Abuhamdia Z.A. Neurobiological foundation for foreign language accents // IRAL. 1987. No. 3. Pp. 203 - 212.

Albert M.L., Obler L.K. The Bilingual Brain: Neuropsychological and Neurolinguistic Aspects of Bilingualism. New York, 1979. 302 p.

Bock M. Wort-. Satz- und Textverarbeitung. Stuttgart, 1978. $111 \mathrm{~S}$.

Bühler K. Sprachtheorie. Stuttgart. 1982.434 S.

(laus G., Ebner H. Grundlagen der Statistik für Psychologen. Soziologen. Pădagogen u. a. Berlin. 1983. $530 \mathrm{~S}$.

Desselmann G. Innere und ăußere Bedingungen des auditiven Sprachverstehens im Fremdsprachenunterricht // DaF. 1983. H. 1. S. 4 - 14.

Desselmann G. Aufgaben und Übungsgestaltung zur auditiven Sprachrezeption // DaF. 1983. H. 6. S. 345 - 350.

Dieling H. Mehr Hortraining im Fremdsprachenunterricht // DaF. 1983. H. 2. S. $106-109$.

Dieling H. In welcher Weise wirkt die muttersprachliche Perzeptionsbasis bei der Wahrnehmung fremdsprachlicher Laute? DaF. 1984. H. 3. S. $170-174$.

Dieling $H$. Das Verhăltnis Lautperzeption-Lautproduktion, untersucht am Beispiel der deutschen Vokale // DaF. 1985. H. 3. S. 174 - 175.

Engelkamp J. Psycholinguistik. München, 1983. $234 \mathrm{~S}$.

Engelkamp J. (Hrsg.) Psychologische Aspekte des Verstehens. Berlin. 1984. 254 S.

Engelke H.-P. Der Versuch der Klassifikation der Alltagsgeräusche und deren Einfluss auf die Sprachverständlichkeit. Bochum. 1971. 35 BL. (Med. Diss.)

Esser U. Versuch eines Resümees der Diskussion "Spracherwerb und Fremdsprachenunterricht" // DaF. 1988. S. 294 - 295.

Esser U., Hirschfeld U. Fremdsprachenlemfachigkeit und phonetische Diskriminationsfahigkeit für Deutsch als Fremdsprache beim Anfangserwerb - Entwicklung eines diagnostischen Prüfverfahrens // DaF. 1984. H. 5. S. 297 - 301.

Esser W.M. Zum konsonantischen Element im deutschen Sprachlautkörper // Wirkendes Wort.1960. Jg. 10. H. 2. S. 68-78.

Fleischer W. Wortbildung der deutschen Gegenwartssprache Leipzig, 1983. $363 \mathrm{~S}$.

Gat J.B., Keith R.W. An effect of linguistic experience // Audiology. 1978. Vol. 17. Pp. $339-345$.

Grassegger A. Versuch zur Erstellung eines auditiv ermittelten Transferinventars deutscher und italienischer Konsonantenrealisationen // IRAL. 1986. Vol. XXV. No. 1, 2. Pp. $127-148$.

Gruhn W. Sprachen lemen - (k)ein Problem? Leipzig. 1984. 181 S.

Günther K. U. a. Wege zur erfolgreichen Fremdsprachenaneignung. Berlin. 1986. $191 \mathrm{~S}$.

Hartmann E. Untersuchung über Sprachverstăndlichkeit und Mindenung der Informationen // ZPSK. Jg. 18. H. 1. S. 1 - 8.

Hăuser D. Ist der Vergleich von Muttersprach - und Fremdsprachenerwerb ein nützliches methodologisches Prinzip? // DaF. 1988. H. 2. S. 98 - 103.

Heidolph K.B., Flămig W., Motsch W. u. a. (Hg.) Grundzüge einer deutscher Grammatik. Berlin, 1981. $1028 \mathrm{~S}$.

Helbig G. Entwicklung der Sprachwissenschaft seit 1970. Leipzig. 1986. 323 S.

Helbig G. Sprachwissenschaft - Konfrontation - Fremdsprachenunterricht. Leipzig. 1981. $159 \mathrm{~S}$. 
Hentschel G. Vokalperzeption und natürliche Phonologie. Eine kontrastive Untersuchung zum Deutschen und Polnischen. München. 1986. $348 \mathrm{~S}$.

Hirschfeld U. Zur Interferenz im Bereich der Phonologie und Phonetik // DaF. 1983a. H. 1. S. $51-55$.

Hirschfeld U. Inhalt. Schwierigkeiten und Grenzen konfrontativer Untersuchungen im Bereich Phonologie / Phonetik // DaF. 1983b. H. 2. S. 102 - 103.

Hörmann H. Einführung in die Psycholinguistik. Darmstadt. 1981. $154 \mathrm{~S}$.

Hofmann J. Das aktive Gedächtnis. Berlin 1982. (русский перевод 1986)

Jakobson R., Halle M. Grundlagen der Sprache. Berlin. 1960. 74 S.

Juhász J.P. Probleme der Interferenz. Budapest. 1970. 174 S.

Kaeding F.W. Hăufigkeitswörterbuch der deutschen Sprache. Steglitz bei Berlin. 1898. VI. $671 \mathrm{~S}$.

Kainz F. Psychologie der Sprache. Bd. 3. Stuttgart. 1965. VII. 571 S.

Kim S. Zur Aspiration der Verschlußlaute an den Morphem- und Wortgrenzen im Deutschen // DaF. 1985. H. 5. S. 303 -306.

Kohler K. Dimensions in the perception of fortis and lenis plosives // Phonetica. 1979. Vol. 36. No. 4 - 5. Pp. 332 - 345.

Kordon U. Sprachsignalerkennung und Sprachsynthese // Radio Fernsehen Elektronik. 1987. Jg. 36. S. $651-655$.

Koster C.J. Word Recognition in Foreign and Native Language. Effects of Context and Assimilation. Dordrecht. 1987. $178 \mathrm{p}$.

Krause M. Zur Perzeption russischer Wörter durch deutschsprachige Hörer. // Wiss. Ztschr. Friedrich-Schiller-Universităt Jena. Gesellschaftwiss. R. 1988. H. 2. S. 141 - 145.

Krause M. Stern A. Zur Bedeutung der auditiven Perzeption für das Erlemen einer Fremdsprache // Wiss. Ztschr. Friedrich-Schiller-Universität Jena. Gesellschaftwiss. R. 1988. H. 3. S. 335 - 337.

Krech [:.-M. (IIrsg.) Großes Wörterbuch der deutschen Aussprache. Leipzig. 1982. $599 \mathrm{~S}$.

Lazarus-Mainka G. Sprecher-Hörer-Interaktion unter Geräuscheinwirkung // Psychologische Aspekte des Verstehens / Hrsg. J. Engelkamp. Berlin. 1984. S. $111-128$.

Lehrplan der Zehnklassigen allgemeinbildenpolytechnischen Oberschule - Russisch // Fremdsprachenunterricht. 1987. H. 11. S. 545 - 553.

Lewandowski Th. Linguistisches Wörterbuch. Bd. 1 - 3. Heidelberg. 1984.

Lindner G. Grundlagen und Anwendungen der Phonetik. Berlin. 1981. 382 S.

Lindner G. Hören und Verstehen. Phonetische Grundlagen der auditiven Lautsprachperzeption. Berlin. 1977. $203 \mathrm{~S}$.

lobacz P. Fonetyczne-leksykalne interakcje w percepcji mowy. Poznan. 1985. 204 S.

l.üdtke $H$. Wirkungsprinzipien von Flexionssystemen: time-sharing und syntagmatisches (jefälle // ZPSK. 1988. Jg. 41. H. 3. S. 438 - 441.

Martinet A. Grundzüge der Aligemeinen Sprachwissenschaft. Stuttgart. 1963. $201 \mathrm{~S}$.

Mattes L.J., Omark D.R. Speech and Language Assessment for the Bilingual Handicaped. San Diego. 1984. 163 p.

Meier H. Deutsche Sprachstatistik. Bd. 1, 2. Hildesheim. 1967. XIII. 442. 150 S.

Meinhold G. Deutsche Standardaussprache - Lautschwăchungen und Formstufen. Jena. 1973. $145 \mathrm{~S}$.

Meinhold G., Stock E. Phonologie der deutschen Gegenwartssprache. Leipzig. 1982. 256S.

Menzerath P. Architektonik des deutschen Wortschatzes. Bonn. 1954. $131 \mathrm{~S}$. 
Miller G.A., Heise G., Lichten W. The intelligibility of speech as a function of the context of the test material // Journ. of Experimental Psychology. 1951. Vol. 41. Pp. 329 - 335.

Müller K. Theorie - Praxis - Beziehungen in der Phonetikausbildung der Russischlehrerstudenten: Diss. B. Magdeburg. 1984. 242 S. (Maschinenschrift)

Murjasov R.Z. Zur Wortbildungsstruktur der Ableitungen mit Fremdsuffixen // DaF. 1976. H. 2. S. $121-124$.

Neisser U. Cognitive Psychology. Prentice Hall, 1967. 351 p.

Oakshott-Taylor J. Acoustic Variability and its Perception: the Effects of Context on Selected Acoustic Parameters of English Words and their Perceptual Consequences. FrankfurtMain. $1980.359 \mathrm{p}$.

Osgood $\mathrm{Ch}$. Language universals and psycholinguistics // Greenberg J. (ed.) Universals of Language. Cambridge. 1963. Pp. 254 - 263.

Reimann B. Phonetisch orientierte Interpretation im fruhen Spracherwerb des Kkinkindes // Zeitschrift für Psychologie. 1986. H. 1. S. 93 - 103.

Salasoo A. Pisoni D.B. Interaction of knowledge sources in spoken word identification // Journal of Memory and Language. 1985. Vol. 24. Pp. $210-231$.

Samuel A.G., van Santen J.P. Johnston J.C. Length effects in word perception: we is better than / but worse than you or them // Journal of Experimental Psychology: Human Perception and Performance. 1982. Vol. 8. Pp. $91-105$.

Savin H.R. Word-frequency effect and errors in the perception of speech // JASA. 1963. Vol. 35. No. 2. Pp. 200-206.

Scharpff P.J. Effects of context and lexical redundancy and continuous word recognition // Proceedings Xlth JCPhS. Tallin, 1987. Vol. 5. Pp. 42 - 45.

Schindler H. Die Widerspiegelung potentieller Interferenz in der Aussprache ausgewählter nichtpalatalisierter/palatalisierter Konsonantenphoneme von Russischlehrerstudenten:

Diss. A. Magdeburg. 1987. 157 S.

Schmidt W. Deutsche Sprachkunde. Berlin, 1985. 312 S.

Sendlmeier W.F. Der Einflu $\beta$ von Qualităt auf die Perzeption betonter Vokale des Deutschen // Phonetica. 1981. Vol. 38. No. 1 - 3. Pp. 291 - 308.

Sendlmeier W.F. Aktualgenese und heuristisches Verhalten in der Worterkennung // Forschungsberichte des Instituts für Phonetik und sprachliche Kommunikation der Universität München. 1983. Bd. 17. S. 45 - 64.

Sendlmeier W.F. A model of the phonetic mental representation of words // Proceedings XIth ICPhS. Tallin. 1987a. Vol. 1. Pp. $68-71$.

Sendlmeier W.F. Auditive judgements of word similarity // ZPSK. 1987b. Jg. 40. H. 4. S. $538-547$.

Stem A.S. Linguistic factors in speech perception // Proceedings XIth ICPhS. Tallin. 1987. Vol. 1. Pp. 72 - 75.

Sumilova E.M. Der Transfer als psychologischer Prozess // DaF. 1983. H. I. S. 19 - 26.

Velickovskij B.M. Wissen und Handeln. Berlin. 1988. 309 S.

Wenk R., Lehmann N. Reschke M. Русский язык. Комплекс учебников и учебных пособий для студентов - будущих преподавателей русского языка. Практический курс по фонетике. 1985. 132 с.

Wiede B. Phonologie und Artikulationsweise im Russischen und Deutschen. Leipzig. 1981. $148 \mathrm{~S}$. 
Wurzel W.U. Der deutsche Wortakzent: Fakten - Regeln - Prinzipien. Ein Beitrag zu einer natürlichen Akzenttheorie // Linguistische Studien. Reihe A. Berlin. 1980. Bd. 68. S. 95 129.

Wurzel W.U. Flexionsmorphologie und Natürlichkeit: ein Beitrag zur morphologischen Theoriebildung. Berlin. 1984.223 S.

Zawadzka E. Ausgewählte psycholinguistische Faktoren des fremdsprachigen Verstehens und ihre Auswirkung auf die didaktische Praxis // DaF. 1983. H. 1. S. 14 - 19.

Zawadzka E. Auditive Fehleridentifizierung unter psycholinguistischem Aspekt // DaF. 1988. H. 4. S. $218-230$.

Zimmer H.D. Die Repräsentation und Verarbeitung von Wortformen // Handbuch der Lexikologie / Hrsg. Ch. Schwarze, D. Wunderlich. Königstein / Ts: Athenăum. 1985. S. $271-291$.

Адмони В.Г. Морфологическая структура слова немецкого языка. // Морфологическая структура слов в индоевропейских языках. / Ред. В.М. Жирмунский. Н.Д. Арутюнова. М., 1970. С. 182 - 221.

Адмони В.Г. Строй современного немецкого языка. Л., 1972. $312 \mathrm{c.}$

Акопян (Бахарева) Е.В. Влияние лингвистических факторов на восприятие иностранного слова (на материале немецкого языка): Дипл. раб. Л., 1985. 64 с. (Машинопись)

Баландина 3.И. Вероятностное прогнозирование в процессе слухового восприятия слов // Слух и речь в норме и патологии Вып. 5. / Ред. Л.Р.Зиндер и др. Л., 1984. С. 27-37.

Балиашвили Т. Интерференция как проблема двуязычия. Тбилиси. 1988. $213 \mathrm{c.}$

Бахарева Е., Краузе М., Штерн А. Восприятие дериватов: сравнительное исследование немецких и русских производных слов // Деривация и история языка: Тез. докл. на межвуз. науч. конф. Пермь. 1985. С. 184 - 185.

Беляева Б, В. (черки по психологии обучения нностранинм языкам. М., 1965. $228 \mathrm{c}$.

Белякова Г.А. Обучение французскому произношению: проблема ошибки на слуховом и артикуляционном уровнях // Вестник Ленингр. ун - та. Сер. 2. 1988. № 2. С. $51-57$.

Биева Е.Г. О понимании текстов на родном и иностранном языках // Лингвистические и психолингвистические исследования языка и речи / Ред. В.Н. Овчинников. А.М. Шахнарович. М., 1986. С. 31 - 38.

Бондарко Л.В., Вербицкая Л.А. О маркированности признака мягкости русских согласных // ZPSK 1965. Jg.18. H.I. S. 119 - 126.

Бондарко Л.В., Кукольщикова Л.Е., Павлова Л.П., Светозарова Н.Д., ЩТтерн А.С. Восприятие фонем в слогах ризличных типов // Анализ речевых сигналов человеком / Ред. А.В.Венцов. Л., 1971. С. 182 - 192.

Бондарко Л.В. Акустическая характеристика речи // Слух и речь в норме и патологии. Вып. І. / Ред. Л.Р.Зиндер и др. Л., 1974. С. 9 - 24.

Бондарко Л.В.. Зиндер Л.Р. Исследование фонетики // Основы теории речевой деятельности / Ред. А.А. Леонтьев. М., 1974. С. 145 - 161.

Бондарко Л.В. Звуковой строй современного русского языка. Л., 1977. 175 с.

Бондарко Л.В. Фонетическое описание языка и фонологическое описание речи. Л.. $1981.199 \mathrm{c}$.

Бондарко Л.В., Вербицкая Л.А., Гордина М.В. Основы общей фонетики. Л.. 1983. $119 \mathrm{c}$. 
Вайнрайх У. Одноязычие и многоязычие // Новое в лингвистике. Вып. VI. / Ред. В.Ю. Розенцвейг. М., 1972. С. 25 - 60.

Вайнрайх У. Языковые контакты. Киев. 1979. 263 с.

Bейсалов Ф.Е.О. Варнантность гласных фонем современного немецкого языка (экспериментальные данные и теоретические проблемы): Дис. ... д-ра филол. наук. Баку, 1980. 327 с. (Машинопись)

Венцов А.В., Охарева Н.Г., Светозарова Н.Д. Смирнова Е.Ю., Штерн А.С. Учебные задания для работы со словарём квазиомонимов. Л., 1985. $55 \mathrm{c.}$

Вербицкая Л.А., Гордина М.В., Кукольщикова Л.Е. Дифференциация звуковой стороны русского языка в условиях русско-украинского двуязычия // Вестник Ленингр. ун - та. Сер. 2. 1986. № 2. С. 53 - 57.

Верещагин Е.M. Психологическая и методическая характеристика двуязычия. М., 1969a. 89 c.

Верещагин Е.M. Вопросы теории речи и методики преподавания иностранных языков. М., 19696. 89 с.

Виноградов В.А. Лингвистические аспекты обучения языку. Ч. І. М., 1972. 59 с.

Вшивкова Т.В. Экспериментальное исследование начального этапа антиципации при пониманин текста // Лингвистические и психолингвистические исследования языка и речи / Ред. В.Н. Овчинников. А.М. Шахнарович. М., 1986. С. 39 - 47.

Гатунов В.И., Королёва И., Шургая Г.Г. Взаимодействие двух полушарий в процессе обработки речевой информации // Акустика речи и слуха / Ред. Л.А. Чистович. Л., 1986. C. $127-143$.

Гоер А., Гоер Г. Первый период языковой деятельности ребёнка // Детская речь / Ред. Н.А.Рыбников. М., 1927. С. 23 - 50.

Гурбанов Е.Ю., Зиндер Л.Р. Приниипы построения испытательных таблиц русской речи и сопоставление испытательных таблиц ВКИАС и НИСО МАП // Труды Академии. Л.: ВКИАС, 1954. С6. 40. С. 46 - 77.

Данилов А.В. Исследование механизмов восприятия слова в затруднённых условиях: Автореф. дис. ... канд. филол. наук. Л., 1985. 20 с.

Дешериев Ю.Д., Протченко И.Ф. Основные аспекты исследования двуязычия и многоязычия // Проблемы двуязычия и многоязычия / Ред. П.А. Азимов и др. М., 1972. C. $26-42$.

Джапаридзе 3.Н. Перцептивная фонетика. Тбилиси. 1985. 118 с.

Жинкин Н.И. Механизмы речн. М., 1958. 370 с.

Жинкин Н.И. Речь как проводник информации. М., 1982. 157 с.

Залевская А.А. Межъязыковые сопоставления в психолингвистике. Калинин. 1977а. $84 \mathrm{c}$.

Залевская А.А. Проблема организации внутреннего лексикона человека. Учебное пособие. Калинин. 19776.83 с.

Залевская А.А. Вопросы организации лексикона человека в лингвистических и психолингвистических исследованиях. Калинин, 1978. $87 \mathrm{c.}$

Залевская А.А. Психолингвистические проблемы семантики слова. Калинин. 1982. $80 \mathrm{c}$.

Залевская А.А. Слово как опорный элемент сознания // Тез. IX Всесоюз. симп. по психолингвистике и теорин коммуникации. М., 1988. С. 68 - 69. 
Зимняя И.А. Смысловое восприятие речевого сообщения // Смысловое восприятие речевого сообщения ( в условиях массовой коммуникации) / Ред. Т.М. Дридзе. А.А. Леонтьев. М., 1976. С. 5 - 33.

Зиндер А. Штерн А.С. Некоторые особенности восприятия слова слабослышашими детьми // Слух и речь в норме и патологии. Вып. 6. / Ред. Л.Р.Зиндер и др. Вып. 6. Л., 1986. С. $33-40$.

Зиндер Л.Р. Русские артикуляционные таблицы // Труды Академии. Л.: ВКИАС, 1951. С6. 29 - 30. С. 31 - 46. $119-198$.

Зиндер Л.Р. Общая фонетика. Л.. 1979. 312 с.

Зиндер Л.Р., Штерн А.С. Факторы, влияющие на опознание слов // Магтериалы IV Всесою3. симп. по психолингвистике и теория коммуникации. М., 1972. С. 100 108.

Зиндер Л.Р., Штерн А.С. Принципы отбора текстового материала // Слух и речь в норме и патология. Вып. 4. / Ред. Л.Р.Зиндер и др. Л., 1982. С. 10 - 15.

Зиндер Л.Р., ЦІтерн А.С. Лингвистический аспект тестирования // Речевые тесты и их применение / Ред. Л.В. Златоустова. М., 1986. С. 6 - 20.

Зинченко В.П. Теоретические проблемы психологии восприятия // Инженерная психология / Ред. А.Н. Леонтьев. М.. 1964. С. 231 - 263.

3убкова Л.Г. Звуковая форма значащих единиц языка и структурные характеристики фонем (к вопросу об актуальных зацачах фонолюгии) // Изв. АН СССР. Сер. лит. и я3. 1988. № 4. C. 340 - 352.

Иванов В.В.. Новиков А.А. Современный русский язык / Теоретический курс. Фонетика. М., 1985. 158 с.

Имедадзе Н.В. Экспериментально-психологические исследования овладения и владения вторым языком. Тбилиси. 1979. 229 с.

Интерференция звуковых систем / Ред. Л.В. Бонларко. Л.А. Вербицкая. ЛІ., 1987. 280 с.

Исенина Е.И. О структуре семантической установки при восприятии речи // ГІсихологические и психолингвистические проблемы владения и овладения языком / Ред. А.А. Леонтьев. Т.В. Рябова. М., 1969. С. 104 - 115.

Исманлов М.С. Раннее двуязычие и его исследования // Лингвистические и психолингвистические исследования языка и речи / Ред. В.Н. Овчинников. Д.М. Шахнарович. М., 1986. С. $110-119$.

Карлинский А.Е. Основы теории взаимодействия языков и проблема интерферен ции: Автореф. ... д-ра филол. наук. Киев. 1980.48 с.

Касевич В.Б. Элементы общей лингвистики. М., 1977. 183 с.

Касевич В.Б. Морфонология. Л., 1986. 161 с.

Касевич В.Б. Цельность языковых единиц в системе и в речевой деятельности // Вестник Ленингр. ун-та. Сер. 2. 1987. № 4. С. 49 - 56.

Кащнельсон С.Д. Общее и типологическое языкознание. Л., 1986. 298 с.

Копьленко О.М. Инвариантная природа смысла и понимание // Механизм речемысли: Способности. Целиноград. 1967. С. 56 - 58.

Кубрякова Е.С. Морфологическая структура слова в германских языках // Морфо:огическая структура слова в индоевропейских языках / Ред. В.М. Жирмунский. Н.Д. Арутюнова М., 1970. С. $179-182$.

Кузнецова А.И., Ефремова Т.Ф. Словарь морфем. М., 1986.1132 с. 
Кукольщикова Л.Е., Охарева Н.Г., Штерн А.С. Восприятие слова как выбор из класса похожих слов // Звуковой строй языка / Ред. Р.И. Аванесов. М., 1979. С. $166-170$.

Курбякова Е.С. Основы морфологического анализа (на материале германских языков). М., 1974. $319 \mathrm{c}$.

Леонтьев А.А. Слово в речевой деятельности. М., 1965.245 с.

Леонтьев А.A. Психолингвистические единицы и порождение речевого высказывания. М., 1969. $307 \mathrm{c.}$

Леонтьев А.А. Принцип коммуникативности и психологические основы интенсификации обучения иностранным языкам // РЯЗР. 1982. № 4. С. 48 - 53.

Ломов Б.Ф. Человек и техника. М., 1966. 464 c.

Іущихина И.М. Аудирование речевых сообщений в условиях белого шума: Автореф. дис. ... канд. филол. наук. Л., 1965. 18 с.

Лэмберт У., Гавелка Дж., Кросби С. Зависимость двуязычия от условий усвоения языка // Новое в лингвистике. Вып. VI. / Ред. В.Ю. Розенцвейг. 1972. С. 241 - 253.

Любимова Н.А. Фонетическая интерференция. Л., 1985. 55 с.

Іюбимова Н.А. Фонетический аспект общения на неродном языке. Л., 1988. $195 \mathrm{c}$.

Мазлумян В.С. К проблеме восприятия слова в тексте // Учён. зап. МГИИЯ. Вып. 243. M.. 1985. C. 44 - 54.

Макарова А.Н.. Туркенбаев Н.У. Смысловое членение и восприятие русской речи // Механизм рече-мысли: Способности. Целиноград, 1967. С. 72 - 75.

Маслов Ю.С. Введение в языкознание. М., 1987. 272 с.

Медведко Е.ПТ. Люблинская В.В. Полезные прнзнаки при восприятии глухих и звонких конечных щелевых согласных (на материале русского. казахского и английского языков) // Вестник Ленингр. ун-та. Сер. 2. 1987. № 3. С. 70 - 76.

Методика / Ред. А.А. Леонтьев. М., 1988. 180 с.

Миньяр-Белоручев Р.К. Механизм переключения с одного языка на другой в условиях билингвизма // Учён. зап. МГИИЯ. Вып. 260. М.. 1986. С. 31 - 38.

Мурзин Л.М., Штерн А.С. Текст и его восприятие. Свердловск. 1991. 170 с.

Наумов В.В. Бифонемные сочетания гласных (экспериментально-фонетическое исследование на материале немецкого языка): Автореф. дис. ... канд. филол. наук. Л.. $1982.14 \mathrm{c}$.

Нехай О.А., Поплавсакая Т.В. Сравнительная типология английского и белорусского языков. Минск. 1983. $173 \mathrm{c}$.

Никонов В.А. Фоностатические измерения межъязыковых расстояний // Исследования по фонологии / Ред. С.К.Шаумян. М., 1966. С. 285 - 297.

Отчёт кафедры фонетики и методики преподавания иностранных языков. Л., ЛГУ, 1988. (Машинопись).

Плохинский Н.А. Алгоритмы биометрии. М., 1967.81 с.

Плохинский Н.А. Дисперсионный анализ силы влияния // Новое в биометрии / Ред. Н.А. Плохинский. М., 1970. С. 31 - 67.

Потапова Р.К. Акустическая характеристика компонентов слоового стыка // Исследования по фонологии / Ред. С.К.Шаумян. М., 1966. С. 401 - 406.

Потапова Р.К. Слоговая фонетика германских языков. М., 1986. 144 с.

Прогно3 в речевой деятельности / Отв. ред. Р.М.Фрумкина. М., 1974. 238 с. 
Роднянский В.Л. О роли ключевого слова в понимания текста // ГІсихолингвистические проблемы семантики и понимания текста / Ред. А.А.Залевская. Калинин. 1976. С. $106-114$.

Розенцвей В.Ю. Языковые контакты. М., 1972.80 с.

РОСА: Отче̌т ЛЭФ ЛГУ. Л., 1973. 176 с. (Машинопись).

Самуйова Н.И. Фонетическая интерференция и обучение языку // IІсихолингвистика и обучение иностраниев русскому языку / Ред. А.А. Леонтьев. Т.В. Рябова. M., 1972. C. $23-29$.

Сапожков М.А. Речевой сигнал в кибернетике. М., 1963. 452 с.

Сахарный Л.В. Психолингвистические алекты тоорин словообразования. JI.. 1985.97 с.

Сахарный Л.В. Введение в психолингвистику. Л.,1989. 181 с.

Свиридова С.П. Исследование возможностей применения дисперсионного анализа в психолингвистических зкспериментах (на примере гелиевой речи): Дипл. раб. Л., 1987. (Машинопись).

Сибирский С. Штерн А.С. Экспериментальная проверка методики введения ключевых слов // Лингвистические основы изучения русского языка как неродного. Тез. докл. V Респ. науч. конф. Баку, 1979. С. 54 - 55.

Слобин Д. Когнитивные предпосылки развития грамматики // Психолингвистика / Ред. А.М. Шахнарович. М., 1984. С. 143 - 207.

Соколов А.Н. Внутренняя речь и мышление. М., 1968. 248 с.

Сопоставительная лингвистика и обучение языку / Ред. В.Г.Ярцева. М., 1987. С. 5 - 26.

Справочник по инженерной психологии / Ред. Б.Ф.Ломов. М., 1982. 368 с.

Суник О.П. Общая теория частей речи. М. - Л., 1966. 132 с.

Трубецкой Н.С. Избранные труды по фонологии. М., 1987. 559 с.

Факторы, обуславливакощие восприятие речи в трудньх условиях: Отчёт ЛЭФ ЛГУ. Л.: ЛГУ, 1971. 25 с. (Машинопись).

Федина 3.И.. Рудая Г.Е. О влиянии некоторых лингвистических факторов на восприятие речи при тугоухости // Слух и речь в норме и патологии. Вып. 1. / Ред. Л.Р. Зиндер и др. Л., 1974. С. 48 - 55.

Фонетика спонтанной речи / Ред. Н.Д. Светозарова. Л., 1988. 248 с.

Фрумкина Р.М., Василевич А.П. Получение оценок вероятностей слов психометрическими методами // Вероятностное прогнозирование в речи / Ред. Р.М. Фрумкина. М., 1971. С. 7 - 28.

Фрумкина Р.М. Василевич А.П., Герганов Е.Н. Субъективные оценки частот злементов текста как прогнозирующия фактор // Вероятностное прогнозирование в речи / Ред. Р.М. Фрумкина. М., 1971. С. 70 - 93.

Фрумкина Р.М. Цвет, смысл, сходство (аспекты психолингвистического анализа). M., 1984. $175 \mathrm{c}$.

Хауген 3. Языковый контакт // Новое в лингвистике. Выл. VI. / Ред. В.Ю. Розенивейг. М., 1972. С. 61 - 80.

Чугаева Т.Н. Механизмы аудирования родной и иноязычной речи (эксперименталностатистическое исследование на материале американского варианта английского языка): Дис. ... канд. филол. наук. Л., 1989. 257 с. (Машинопись).

Чугаева Т.Н., Штерн А.С. Изучение механизма восприятия речи в условиях интерферениии // Экспериментально-фонетические исследования. Вып. 2. / Ред. Л.В. Бондарко. Л., 1989. С. $59-69$.

Чуковский К. От двух до пяти. Минск, 1988. 366 с. 
Щвачкин Н.X. Развитие рсчевых форм у младшего дошкольника // Вопросы психологии ребёнка дошкольного возраста. М.-Л., 1948.

Шехтер М.С. Зрительное опознание. Закономерность и механизмы. М., 1981. 264 с.

Щтерн А.С. Сбалансированные артикуляционные таблицы // Слух и речь в норме и патологии. Вып. 2. / Ред. Л.Р.Зиндер. Л., 1977. С. 16 - 22.

Штерн А.С. Лингвистические факторы в восприятии речи // Слух и речь в норме и патология. Вып. 3. / Ред. Л.Р. Зиндер. Л., 1980. С. 10 - 16.

Џтерн А.С. Влияние лингвистических факторов на восприятие речи: Дис. ... канд. филол. наук. Л., 1981. 251 с. (Машинопись).

Штерн А.С. Артикуляционные таблицы. Л., 1984. 40 с.

Щтерн А.С. Слово и текст: сходство и различие в восприятия // Семантика целого текста. М., 1987. С. $164-165$.

Щтерн А.С., Элькин Ю.А. Опознание слова при снижении слуха // Совершенствование методов диагностики и преодоления нарушений речи / Ред. В.А. Ковшиков Л., 1989. С. $144-151$.

Щерба ЛІ.В. Языковая система и речевая деятельность. Л.. 1974. 428 с.

Щербакова И.А. Механизмы восприятия французского слова русскими учашимися: Дипл. раб. Л., 1984. (Машинопись). 


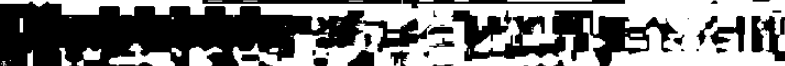

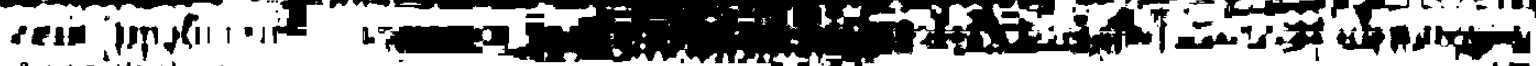

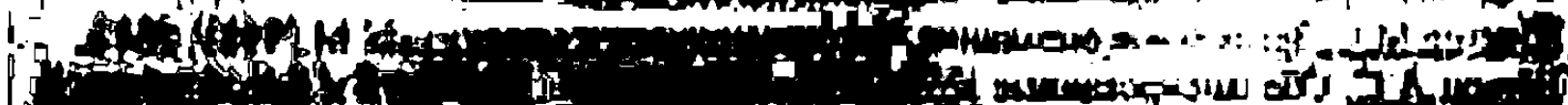

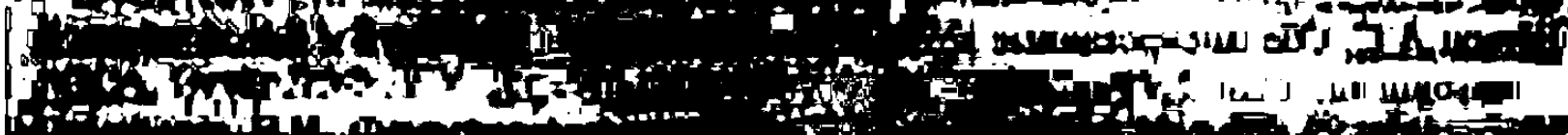

ot:- -

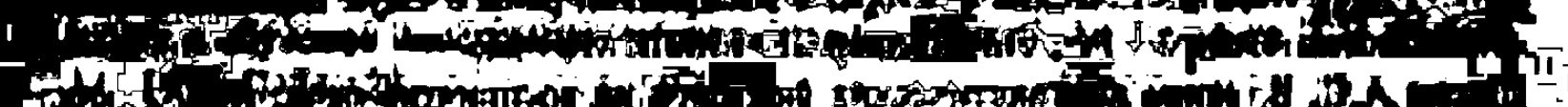

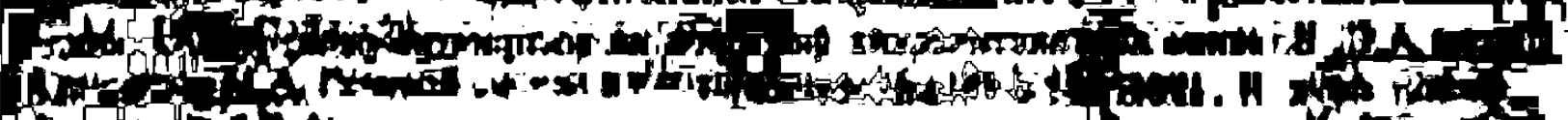

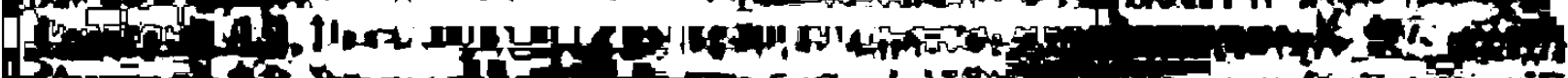

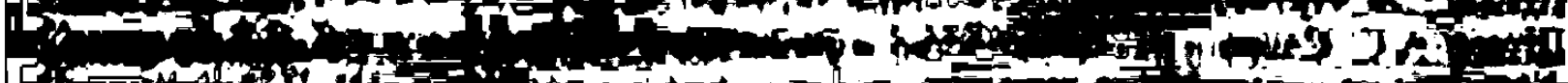
L

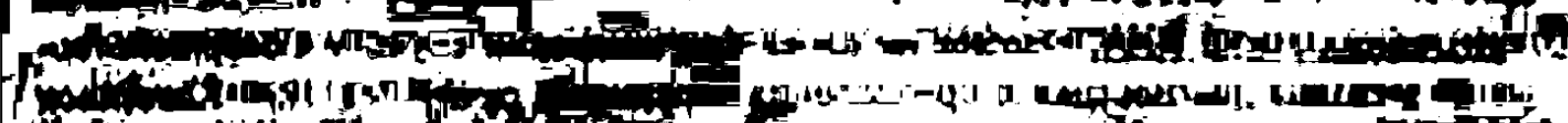

1.

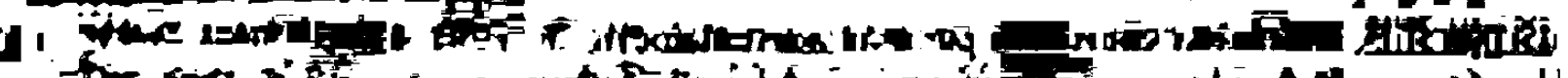
L

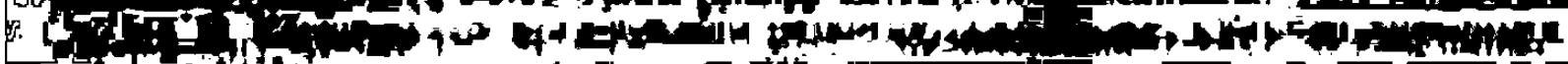

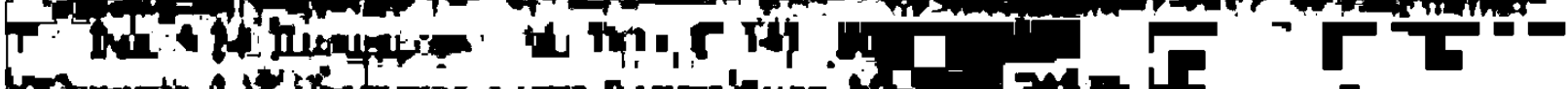

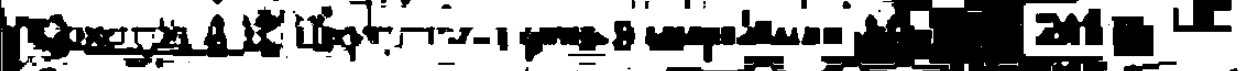

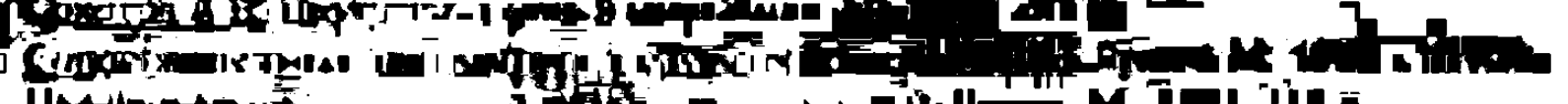

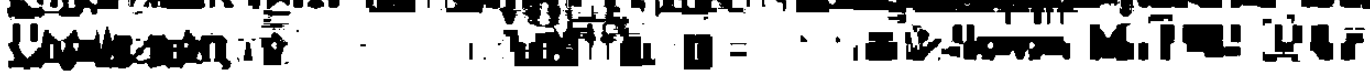

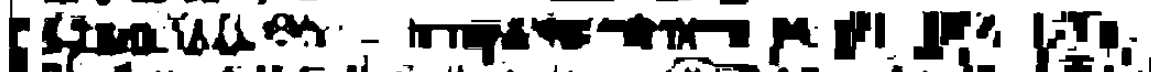

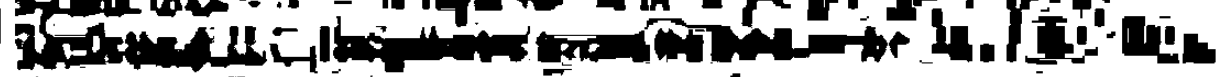

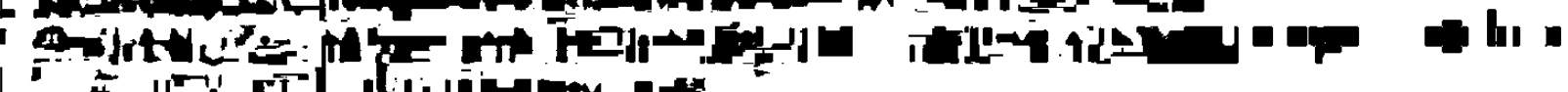

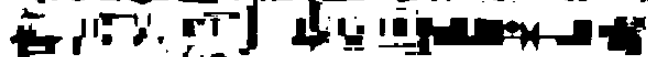

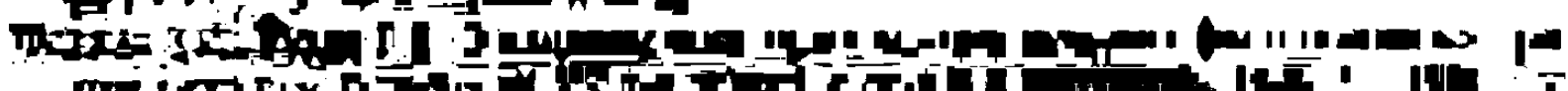
mi int Tि

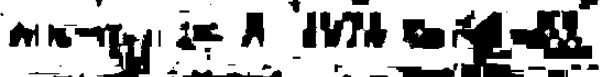

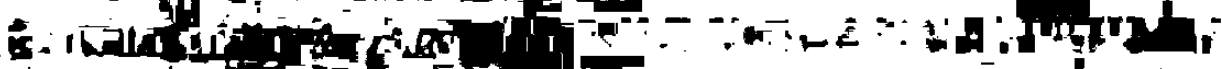

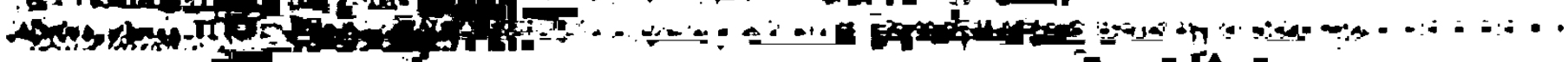

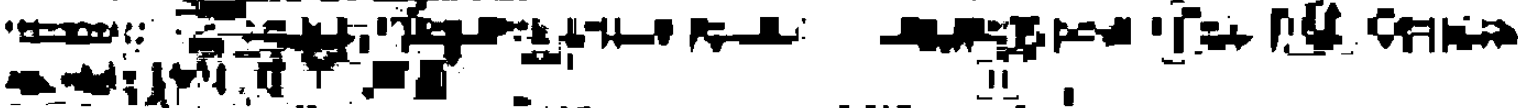

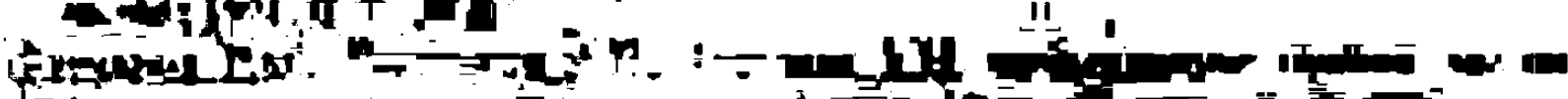

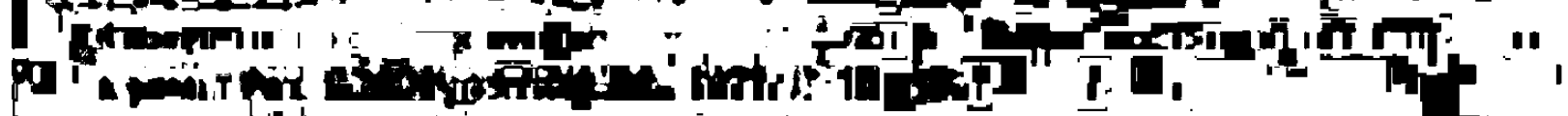

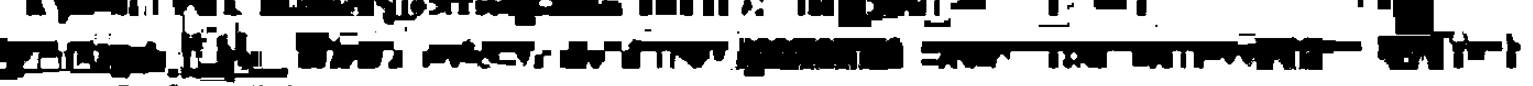
24. Jent?

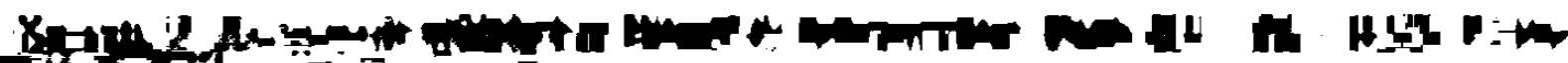

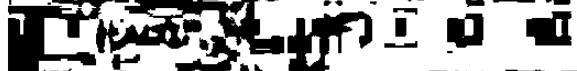

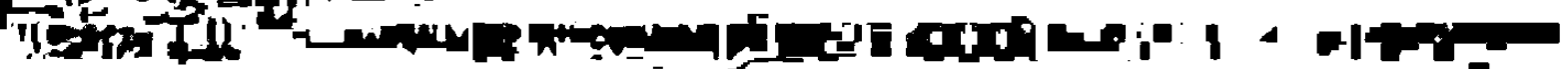

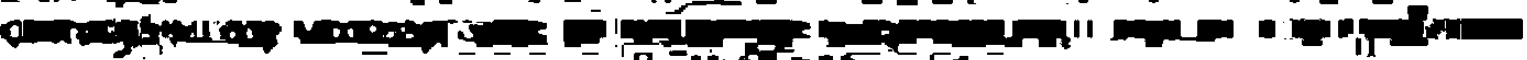

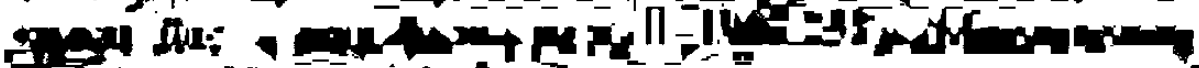

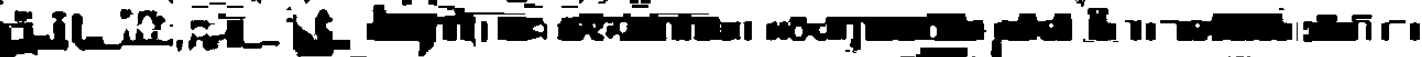

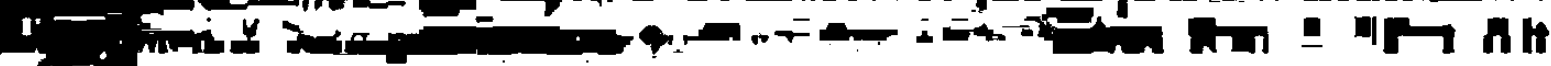

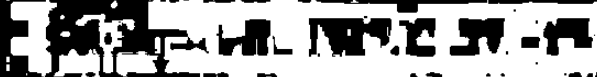

ר

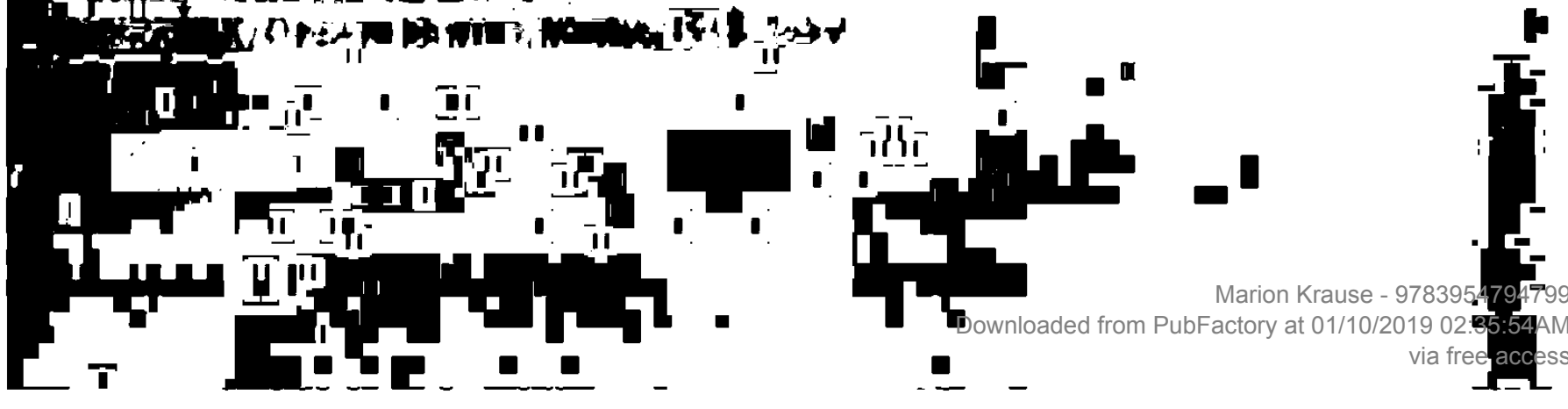




\section{9. ПРИЛОЖЕНИЕ 1}

Русская программа

Таблица I

интересный

пионер

юный

советский

мыть

подбородок

путина

становиться

ящерица

два

рука

спросить

ТВой

мыс

следовать

жить
интересоваться
гул
взгляуть
учитель
здоровый
комната
сахар
изменить
вниз
фотоаппарат
галлинский
черепаха
нос
стул

макет

слабый

посмотреть

мой

заступ

авторучка

современный

пятьдесят

возглас

гулять

мельница

восемьдесят

снять

тридиать

шарф

сто

новый

спина

толщина

6ок

\section{Таблица 2}

зонт
миллион
мешочничество
голова
бить
сей
воздух
мировой
сал
женский
челнок
встретиться
американский

больше
спать
хороший
ширма
путовица
мир
гречиха
отвечать
путаница
морж
следующий
хотеть
заниматься

укрытие
уйти
скамейка
туман
жук
памятник
вишня
позвать
стать
коричневый
улица
девять
комбинат

Bce

прав

работать

девятнадцать

крот

земля

познакомиться

важный

полотенце

три

четыре

комбинат 
Таблица 3

$\begin{array}{ll}\text { гри6 } & \text { кенгуру } \\ \text { вниз } & \text { долгий } \\ \text { энергия } & \text { снимок } \\ \text { собственный } & \text { три } \\ \text { штаб́ } & \text { тарелка } \\ \text { морж } & \text { свой } \\ \text { занавес } & \text { условие } \\ \text { твой } & \text { двадцать } \\ \text { мотоцикл } & \text { ножницы } \\ \text { платок } & \text { семнадиать } \\ \text { лётчик } & \text { мышь } \\ \text { держать } & \text { дуть } \\ \text { смета } & \text { пять }\end{array}$

национальный

смочь

настоящий

жемерность

выходить

дать

думать

путаница

предупредить

советский

понимать

свет

большой

часы

поверхность

кнвать

ynop

обезьяна

средний

будуший

чай

начинаться

доставить

одиннадцать 


\section{0. ПРИЛОЖЕНИЕ 2}

Немецкая программа

Таб.лица I

Granit
Aphasie
Gerippe
gratulieren
ratsam
fragen
schrumpfen
Marxist
schematisch
abprallen
heikel
Frist
Tier

schlimm
Kampf
klumpig
Gleichnis
schmeichlerisch
Gedanke
Erziehung
wiegen
definitiv
mutig
Demonstrant
Bache
Wucherer

entsinnen

gut

Uhr

teilnehmen

Regal

Eintrag

Institut

zagen

steril

Glaserei

streicheln

Absatz.

halbseiden fundamental

Gemeinsamkeit

Fall

intemational

Urkunde

Eid

Bilanz

schrill

dumpf

Keil

Tumult

\section{Tаблица 2}

Spelunke
Kabale
Fluch
erkundigen
konservativ
sitzen
gesunden
Geist
sinnwidrig
belustigen
behutsam
Gummi
Feier

formal
Sitzung
glatt
Dung
schlicht
Freiheit
Gleichung
beschlagnahmen
destruktiv
liberal
Krug
Giebel
Reisig

ticken

gleich

Zeit

Schleier

Gliederung

dental

politisch

Konditorei

Struktur

putzen

Thematik

Sinfonie

geheim

Schmeichelei

Fabrik

Sinn

Disput

linieren

Sack

feist

Geweih

reinigen

spektral

karg 


\section{Tаб.лица 3}

$\begin{array}{ll}\text { Gefilde } & \text { dumm } \\ \text { Adjunkt } & \text { Bild } \\ \text { Mahnmal } & \text { gering } \\ \text { spielen } & \text { Schalmei } \\ \text { mannigfaltig } & \text { gruselig } \\ \text { haben } & \text { Gesundheit } \\ \text { deklarieren } & \text { Gedicht } \\ \text { Republik } & \text { ermuntem } \\ \text { wild } & \text { maritim } \\ \text { absorbieren } & \text { zart } \\ \text { heilsam } & \text { Mais } \\ \text { Hindernis } & \text { Falbe } \\ \text { Kleinigkeit } & \text { Fossil }\end{array}$

rascheln

gerade

Milch

Hudelei

Mineral

schneiden

Gleichgültigkeit

Him

Zucker

glucksen

plump

Brut

schlucken
Besichtigung

habil

schief

Wein

Darstellung

hart

Gas

Spirale

Muskel

simultan

gallig

$\begin{array}{ll}\text { Ta6nuya } 4 & \\ \text { Katapult } & \text { lustig } \\ \text { Kellerei } & \text { Geburt } \\ \text { Stimulus } & \text { illegal } \\ \text { heiraten } & \text { Pult } \\ \text { handelsublich } & \text { dreist } \\ \text { beeinflussen } & \text { Haar } \\ \text { lasieren } & \text { Resultat } \\ \text { Glas } & \text { demonstrieren } \\ \text { reich } & \text { steinem } \\ \text { schlurfen } & \text { geduldig } \\ \text { unliebsam } & \text { Kathedrale } \\ \text { Fisch } & \text { Binge } \\ \text { Temperatur } & \text { Lagune }\end{array}$

\section{Taблuya 4}

Katapult

Kellerei

Stimulus

handelsúblich

beeinflussen

lasieren

Glas

reich

schlurfen

Fisch

Lagune

$\begin{array}{ll}\begin{array}{l}\text { umstimmen } \\ \text { gemeinsam }\end{array} & \begin{array}{l}\text { Geige } \\ \text { demokratisch }\end{array} \\ \text { Buch } & \text { Ring } \\ \text { Grab } & \text { Gips } \\ \text { Kanal } & \text { Gemeinde } \\ \text { stattfinden } & \text { bleiern } \\ \text { Intoleranz } & \text { dominant } \\ \text { Filtrat } & \text { zivil } \\ \text { Kapital } & \text { Gnu } \\ \text { peinigen } & \text { empfangen } \\ \text { Broschur } & \text { Pfund } \\ \text { munter } & \\ \text { Leidenschaf } & \end{array}$




\section{КОММЕНТАРИЙ К РАБОТЕ}

Представленное вниманию читателя исследование было защищено в октябре 1989 г. на заседании Ученого Совета Д 063.57 .08 при Ленинградском университете. Оно было принято как диссертация на соискание ученой степени кандидата филологических наук. До сих пор с ней можно было ознакомиться по разосланному автореферату и по тем малочисленным экземплярам, которые имеют в своих фондах некоторые крупные библиотеки. Помимо этого, еще до защиты диссертации некоторые аспекты исследования были освещены в ряде статей. Настоящая публикация позволяет дополнить картину не опубликованными ранее частями исследования; таким образом, перед читателем встает целостная картина научного труда в том виде, в котором он был защищен. ${ }^{59}$

Но изучение вопросов механизма восприятия продолжалось и после защиты диссертации. Дальнейшей разработке подверглись также другие модели восприятия речи (см., напр., обзор [Sendlmeier 1987; McQueen, Cutler 1997]). Естественно, что на этом фоне и с расстоянием больше 10 лет часть результатов получает более обобщенную трактовку. Некоторые выводы видятся ярче, некоторые аспекты работы становятся более значимыми. Поэтому в настоящем комментарии ставится три задачи: во-первых, часть результатов освещается в контексте актуальной по сей день дискуссии об адекватных моделях восприятия речи; вовторых, представляются основные направления дальнейших разработок, проведенных в русле модели механизма восприятия и, в-третьих, дается актуализованный список публикаций, связанных с темой работы. ${ }^{60}$

Как мне кажется теперь, наиболее общим и плодотворным итогом исследования оказалось подтверждение правамерности использованной статистической модели. Контроль целого комплекса разных лингвистических признаков позволил определить их значимость для достижения результата деятельности, в данном случае - опознания слов. Относящиеся к нему виды информации косвенно проливали свет на сам процесс восприятия и на те виды репрезентации знания, которые хранятся в памяти и активизируются в ситуации восприятия. Возможно, с помощью современных методов исследования, в частности, позитроннозмиссионной (PET) и магнитно-резонансной томографией (MRT; cp.

${ }^{59}$ Единственное отклонение заключается в введении нескольких сносок. в которых учитываются замечания оппонентов. Главным образом они касались сжатости некоторых пояснений. Я постаралась дать этим положениям более полную трактовку в духе монх тогдашних ответов на замечания оппонентов. Оппонентами на защите были: 3.Н. Джапаридзе и Н.А. Слепокурова. В качестве ведущей организации выступало Јенингралское отделение Института языкознания Академии Наук.

60 Этот список не претендует на полноту. 
напр. [Mayer et al. 1999]), удастся проникнуть в процедуральные и временные характеристики процесса восприятия. Но при этом безусловно должны быть учтены все те научные данные, которые характеризуют процесс через причастные к нему факторы.

Свою диагностичность модель показала при анализе структуры механизма восприятия в разных условиях приема, разных степеней сформированности этого механизма. С одной стороны, она позволяет сделать достаточно конкретные, количественно и качественно обоснованные выводы о развитии языковой компетенции на неродном языке. С другой стороны, она может быть использована как индикатор сложности приема как в чужом, так и в родном языке [Krause 1992].

Работоспособность примененной статистической модели подтверждалась в целом ряде сопряженных научных исследований, результаты которых были обобщены в монографиях А.С. Штерн [Штерн 1992; Мурзин, Штерн 1991]. Было изучено восприятие разных лингвистических единиц: слогов, слов, предложений, текстов. Были варьированы типы помехи - как по характеру, так и по величине. Исследования проводились с детьми и взрослыми, людьми с нормальным и пониженным слухом, с носителями языка и иностранцами, с афатиками и людьми без речевых расстройств, с естественной и синтезированной речью, с "гелиевой речью" и речью через воздух. На этой впечатляющей базе экспериментальных данных А.С. Штерн разработала оригинальную и комплексную теорию восприятия устной речи [Штерн 1992].

В последнее время метод дисперсионного анализа в том виде, в котором он был апробирован в перечисленных выше исследованиях, нашел применение и в социолингвистике [Ерофеева Т. 1995; Ерофеева Т., Ерофеева Е., Грачева 2000; Ерофеева Е. 2000]. Он показал себя интересным и плодотворным расширением имеющегося в распоряжении социолингвистики инвентаря статистических подходов. И здесь преимущество метода заключается в том, что он работает с целым комплексом взаимосвязанных, но расчлененных (и сбалансированных) социолингвистических факторов одновременно и позволяет определить весомость этих же факторов в общей иерархии. Метод также был применен при изучении развития языковой компетенции в онтогенезе [Овчинникова и др. 2000].

Результаты исследования по динамике механизма восприятия вносят свой вклад в дискуссию об имеющихся моделях восприятия. Остановимся на некоторых, наиболее важных аспектах.

1. Восприятие работает по гибкому механизму, который в состоянии приспосабливаться к изменяюшимся условиям и задачам. Это не жесткий алгоритм, установленный раз и навсегда, а комбинация слож- 
ных стратегий, в которых участвуют разные по характеру и комплексности структуры и процессы. Им, видимо, соответствуют ментальные репрезентации (эталоны) различной степени сложности.

Так, дальнейшую разработку получил вопрос о значении морфем и квазиморфов для опознания слов [Краузе, Чугаева, Штерн 1991]. Согласно нашим данным, такие структурные и функциональные единицы как морфемы имеют свои корреляты во внутреннем лексиконе человека. И если в работе говорится о "субгештальтах", то это как раз подразумевает самостоятельность данного уровня реперезентации языкового знания. Современные исследования исходят из положения о нескольких видах репрезентации знания и нескольких видах единиц восприятия (ср. [Sendlmeier 1987: 69; McQueen, Cutler 1997:567-568]). Эта точка зрения полностью совместима с нашими результатами. Но помимо эталонов, относящихся к фонетическим признакам, звукам, слогам и словам, определенную роль играют и морфемы. Этот наш вывод согласовывается с итогами исследований ассоциативно-вербальной сети [Караулов 1993; Караулов 1999]. Обнаруженные в них виды активизации морфологического и словообразровательного инвентаря языка отражают регулярности, которые подтверждают наличие морфологического компонента в организации внутреннего лексикона человека (см. обзор в [Краузе 1998: 362-363]). Наши же результаты подтверждают их значение для восприятия. Более детальные результаты, учитывающие также словонзменение, получены, например, в работах [Friederici 1987: 86-104; Feldman $1991]$.

2. При восприятии звучащей информации используется множество источников информации (в нашей терминологии - множество признаков материала). Одни скорее связаны с процессами обработки по нисходящей линии (top down), например, признаки "субъективная" и "объективная частота". Другие, в частности признаки фонетического уровня, отражают скорее восходящие процессы (buttom up). Но причастны к механизму восприятия всегда оба направления. Поэтому мы присоединяемся к тем исследователям, которые в своих моделях учитывают наличие обоих движений - buttom up и top down [Sendlmeier 1987]. Какое из них может превалировать, зависит, видимо, как от условий приема, так и от воспринимаемого материала.

Показательны в этой связи результаты по восприятию незнакомых слов (см. параграф 5.6 настоящей публикации), когда перестраивается внимание по отношению к свойствам материала и активизируется несколько иной механизм восприятия. Эти наблюдения согласуются с данными, полученными иными методами и трактуемыми в совершенно иных моделях (см., например, [McQueen, Cutler 1997:574]). 
Такая же гибкость восприятия была продемонстрирована в других детальных исследованиях, например, в работе [Friederici 1987] о роли морфологического членения при опознании слов разных типов и структур.

3. С вопросом о взаимодействии восходящих и нисходящих процессов обработки информации связана также проблема восприятия стимулов целикам и по частяи, не раз затронутая в диссертационном исследовании. Точкой отсчета при обсуждении этой проблемы послужило слово. Но подчеркнем, что это не исключает своего рода целостности тех предполагаемых эталонов, которые представляют в памяти разные уровни языкового знания.

Хотя гештальтпсихология как научная парадигма подвергалась критике за неточности и перегибы, исследовательский опыт последних лет позволил вернуться к истокам этого направления. Это мы наблюдаем в лингвистике текста, где информационная структура и динамика текста рассматриваются с учетом переднего и заднего фонов (напр., [Hopper 1979; Glenberg, Meyer, Lindem 1987]). Такую же тенденцию мы находим в работах по основам психоакустики и восприятия, описывающих принципы организации акустического потока (streaming) [Bregman 1990].

В настоящем исследовании было показано, что некоторые факторы достаточно четко соотносимы с восприятием стимула как целостного образа. Другие же, расчленяя его, характеризуют слово по частям. Вес тех и других может меняться в зависимости от условий приема. Но есть также признаки, которые, по-видимому, не подлежат жесткой классификации и могут функционировать как целостно, так и по частям. Примером этого является фактор "длина в слогах".

4. Структура и динамика охваченных в исследовании механизмов восприятия рассматриваются в пользу идеи о параллельности обработки информации на разных уровнях: текстовом, словесном, морфологическом, слоговом, фонематическом, фонетическом. Во всех проявлениях механизма участвуют признаки разного уровня, хотя их весомость может меняться в зависимости от условий приема. Эти уровни взаимодействуют друг с другом. Даже предположение, что в самом начале анализа принимается решение о том, знаком ли стимул или не знаком (т.е., существует ли целостный след в памяти или его нет), на мой взгляд, не противоречит тезису о параллельности принятия гипотез. Такой первичный анализ скорее всего включает анализ по нескольким особо "выпуклым", критическим признакам; он скореe всего должен идти снизу вверх и сверху вниз.

В чем же видятся основные дезидераты исследования? Во-первых, в будущих работах по восприятию слова следовало бы найти способы к формализации семантических факторов. В частности, должно быть 
учтено место стимула в ассоциативно-вербальной сети [Караулов и др. 1994-1996]. Конечно, очень сильный в этой сети фактор субъективной частоты уже охвачен исследованиями. Но следовало бы также учитывать ассоциативную силу, степень и качество закрепленности слова во внутреннем лексиконе. Возможно, это позволило бы лучше контролировать так называемый эффект списка. Пока мы не учитывали эффекты торможения и активизации, которые могут сказываться на переработке последовательности изолированных слов. Можно предполагать, что "вызов" определенного слова активизирует его языковое окружение, и это, в свою очередь, оказывает влияние на механизм вероятностното прогнозирования.

Такие факторы, как активизация/торможение, а также индекс ассоциативной силы, не сводимы к признакам самих слов, и поэтому были исключены из представленного диссертационного исследования. Но будущие исследования должны идіи дальше. При этом они могут опираться на весь словарь субъективных частот, который был использован в ходе работы с немецким материалом и при сопоставлении оценок, полученных в экспериментах с русскими и немецкими испытуемыми. Списки опубликованы в отдельной статье [Krause 2002].

Второй и главный дезидерат я вижу в учете контекста - не подсознательно активизируемого, а реально присутствующего. Сдвиг лингвистического интереса в сторону текстов питает убеждение, что, конечно, нельзя ограничиваться исследованием базовых лингвистических единиц.

Структурная сложность и многоплановость текстов, комплексность активизируемого при их переработке знания осложняют параметризацию факторов, которые могут повлиять на восприятие текстов. Тем более, что в данном случае нельзя ограничиваться сугубо языковыми факторами. Для русского и английского языков уже существует опыт подхода к тексту [Штерн 1991; Штерн 1992; Чугаева Чугаева 1991; Чугаева 1996]; для немецкого языкового материала он пока не разработан.

Расширение немецкого тестового материала желательно и в дидактических челях. Имеющийся опыт работы со сбалансированными таблицами при обучении аудированию на иностранном языке подробно описан Т.Н. Чугаевой (напр., [Чугаева 2001а; Чугаева 20016]. Первичная тренировка на изолированном словесном материале проводится во многих тренировочных курсах по фонетике, и это оправдывается методическим приемом "от простого к сложному". Но восприятие (и понимание) текста имеет свои закономерности. Механизм восприятия, который был обнаружен для изолированных слов, не покрывает того, что происходит при восприятии слова в контексте [Штерн 1992:73-74]. Поэтому работа по восприятию предложений и текстов, вместе с соста- 
влением соответствующих тренировочных и тестовых материалов, 3аслуживает особого внимания со стороны обучающих иностранному языку. К сожалению, имеющиеся теоретические знания все еще мало учитываются на практике преподавания.

\section{Литература}

Bregman A.S. Auditory scene analysis. Cambridge. 1990. XIII. 773 p.

Feldman L.B. The contribution of morphology to word recognition. // Psychological Research. 53. 1991, Pp. 33 - 41.

Friederici A.D. Kognitive Strukturen des Sprachverstehens. Berlin. 1987. 177 S.

Glenberg A.. Meyer M., Lindem K. Mental models contribute to foregrounding during text comprehension. // Journal of Memory and Language. 26. 1987. Pp. 69 - 83.

Hopper P.J. Aspect and foregrounding in discourse // Givon T. (ed.): Syntax and Semantics. Vol. 12: Discourse and Syntax. New York, 1979. Pp. 213 - 241.

Krause M. Ein Modell zur Beschreibung linguistischer Faktoren der Wortwahmehmung. In: Hess, W., Sendlmeier, W.F. (Hg.): Beiträge zur angewandten und experimentellen Phonetik. Stuttgart, 1992. S. 56 - 69.

Krause M. Subjektive Bewertung von Vorkommenshäufigkeiten: Methode und Ergebnissc. // Glottometrics. 2. 2002. S. $53-81$

Mayer J., Dogil D., Wildgruber D., Riecker A., Ackermann H.. Grodd W. Prosody in speech production. // Proceedings of the XIV ${ }^{\text {th }}$ ICPhS. San Francisco 1999. Pp. 635 638.

McQueen J.M.; Cutler A. Cognitive processes in speech perception. // Hardcastle W.J., Laver J. (ed.) The Handbook of Phonetic Sciences. Cambridge, 1997. Pp. 566 - 585.

Sendlmeier W.F. A model of the phonetic mental representation of words // Proceedings XIth ICPhS. Tallin. 1987. Vol. 1. Pp. 68 - 71.

Ерофеева Е.В. Социопсихологические факторы и лингвистическая вариативность речи (фонетический аспект). // Тексты устной речи. Под. ред. Р.Ф. Касаткиной. Бохум 2000. С. 93 - 103. (Бюллетень Фонетнческого Фонда 7)

Ерофеева Т.И. Социолект: стратификационное исследование. Автореферат дисс. на сонск. уч. степ. д-ра фнлол. наук. С.-Петербург. 32 с.

Ерофеева Т.И., Ерофеева Е.В., Грачева И.И. Городские социолекты: пермская городская речь. Пермь, Бохум 2000. 173 с.

Караулов Ю.Н. Сорокин Ю.А., Тарасов Е.Ф., Уфимцева Н.В., Черкасова Г.А. Русский ассоциативный словарь. Т. 1 - 4. М., 1994 - 1996.

Караулов Ю.Н. Активная грамматика и ассоциативно-вербальная сеть. Москва, 1999. $180 \mathrm{c.}$

Караулов Ю.Н. Ассоциативная грамматика русского языка. Москва. 1993. 331 с.

Краузе М., Чугаева Т.Н.. Штерн А.С. Деривашионньй фактор в распознавании слова // Принцип деривации в истории языкознания и современной лингвистике. Пермь. 1991. C.228-230.

Краузе М. (Review) Караулов, Ю.Н. Ассоциативная грамматика русского языка. // Russian Linguistics. 22. 1998. Pp. 361 - 367.

Мурзин Л.Н., Штерн А.С. Текст и его восприятие. Свердловск. 1991. 172 с.

Овчинникова И.Г., Береснева Н.И., Дубровская Л.А., Пенягина Е.Б. Лексикон младшего школьника. Пермь. 2000. 312 с. 
Чугаева Т.Н Обучение аудированию: восприятие слова и текста. // Прагматические аспекты функционирования языковых единиц. Москва. 1991. С. 217.

Чугаева Т.Н. Соотношение "слово-текст" при обучении аудированию иноязычной речи. //Лингвистические и методические аспекты текста. Пермь. 1996. С.173 - 182.

Чугаева T.H English words. sentences. texts. Английские артикуляционные таблицы. Методическая разработка для развития навыков аудирования. С.-Петербург, Ilермь. 2001 a. 50 c. (CD included)

Чугаева T.H English sentences. from simple to complex. Методическая разработка по аудированию. С.-Петербург, Пермь, 20016.40 с. (CD included)

Штерн А.С. Перцептивный аспект речевой деятельности. С.-Петербург, 1992. 263 с. 